\title{
DETERMINAÇÃO DE UNIDADES ECOLÓGICAS NUM FRAGMENTO DE FLORESTA NATIVA, COM AUXÍLIO DE SENSORIAMENTO REMOTO
}

\author{
ANDRÉ GuStavo Nave
}

Engenheiro Agrônomo

Orientador: Prof. Dr. RICARDO RIBEIRO RODRIGUES

Dissertação apresentada à Escola Superior de Agricultura "Luiz de Queiroz", Universidade de São Paulo, para obtenção do titulo de Mestre em Ciências, Área de Concentração: Ciências Florestais

PIRACICABA

Estado de São Paulo - Brasil

Julho - 1999 
Dados Internacionais de Catalogação na Publicação (CIP) DIVISĀO DE BIBLIOTECA E DOCUMENTAÇĀO - Campus "Luiz de Queiroz"/USP

\author{
Nave, André Gustavo \\ Determinação de unidades ecológicas num fragmento de floresta nativa, com \\ auxílio de sensoriamento remoto / André Gustavo Nave. - Piracicaba, 1999. \\ 167 p. : il \\ Dissertação (mestrado) - - Escola Superior de Agricultura Luiz de Queiroz, 1999. \\ Bibliografia. \\ 1. Floresta nativa 2. Fragmento florestal 3. Sensoriamento remoto 4. Zoneamento \\ florestal I. Titulo
}

CDD 634.94 
Este trabalho é especialmente dedicado aos meus pais, por uma vida inteira de imenso esforço para formação dos filhos e também a minha esposa Glaucia e meu filho Luca.

Também dedico este trabalho a todos os homens que acreditam e lutam para que o ser humano possa viver em harmonia com a natureza. 


\section{AGRADECIMENTOS}

Á Fundação José Pedro de Oliveira, administradora da Reserva Municipal de Santa Genebra, pela autorização e apoio na realização desse trabalho.

Á FAPESP, pelo auxílio financeiro e bolsa concedida.

Á Escola Superior de Agricultura "Luiz de Queiroz", especialmente os Departamentos de Botânica e de Engenharia Rural, pelo uso de suas instalações.

Ao Departamento de Geociências na UNICAMP, pelo fornecimento do recorte da imagem SPOT e uso do LAPIG, onde foram processadas as imagens orbitais.

Ao NMA (Núcleo de Monitoramento Ambiental) de Campinas, pelo fornecimento do recorte da imagem Landsat TM.

Á Prefeitura Municipal de Campinas, CATI, e Instituto Florestal pelo empréstimo das fotografias aéreas.

Ao Prof. Dr. Ricardo Ribeiro Rodrigues, pela orientação deste trabalho, pelos vários anos de conhecimento transmitido e pela nossa amizade.

Ao Prof. Dr. Álvaro P. Crósta, pela boa vontade e precıosa orientação nos processamentos de imagens deste trabalho.

Aos Profs. Dr. Carlos Alberto Vettorazzi e Dr. Rubens Angulo Filho do Departamento de Engenharia Rural da ESALQ/USP que deram grande apoio técnico e instrumental para análise das imagens orbitais e fotografias aéreas.

Ao Marco Aurélio e Ciro Koiti Matsukuma do Instituto Florestal, Dionete Santin que me ajudaram na aquisição das fotografias aéreas.

A todo o pessoal do CEPAGRI - UNICAMP, principalmente à Jurandir Zullo Junior e Rubens Augusto Camareo Lamparelli, na obtenção de imagens de satélite.

Ao Prof. Jorge Y. Tamashiro, por me ajudar no reconhecimento de alguns trechos da Reserva e pelas correções nomenclaturais dessa dissertação.

Ao todos os botânicos que me ajudaram na identificação do material coletado: Dr. Vinícius C. Souza, Dra. Maria Cândida H. Mamede, Prof. Marco Assis, Prof. Jorge Tamashiro, Dr. Lúcia Kawasaki, Fiorela F. Mazini, Prof. Renato Goldemberg e outros. 
Ao Fabiano (Roko), pela ajuda com o GPS na obtenção dos dados para o georreferenciamento das imagens.

Aos amigos André L. Sotopietro, Francisco e Bruno Folegatti, que me ajudaram nos trabalhos de campo.

Ás pessoas que de alguma forma me ajudaram nesse trabalho: Enrico, Patrícia e Marcelo do Instituto de Geociências, Alexandre Coutinho do NMA, Denise da Fundação José Pedro de Oliveira e Scaramuzza.

Á minha esposa Glaucia e filho Luca pelo amor transmitido, incentivo e compreensão nas minhas ausências em alguns momentos de lazer.

Á todos os professores, pós-graduandos, estagiários e funcionários do Departamento de Ciências Biológicas e de Ciências Florestais da ESALQ/USP que direta ou indiretamente contribuiram para realização desse trabalho. 


\section{SUMÁRIO}

Página

RESUMO. VIII

SUMMARY . $\mathrm{X}$

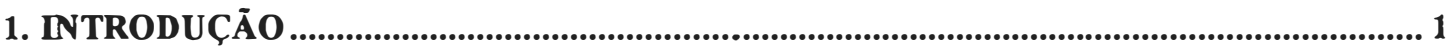

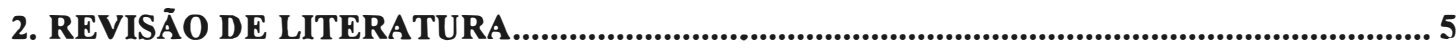

2.1. SITUAÇÃO DA VEGETAÇÃO NATURAL NA REGIÃO DE CAMPINAS ........................................... 5

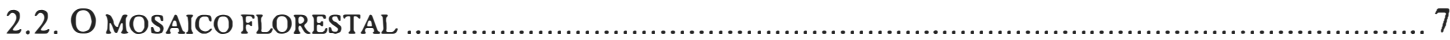

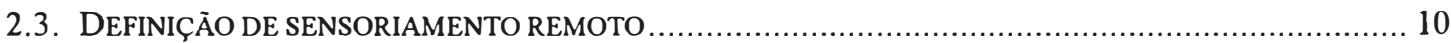

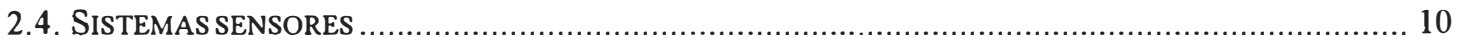

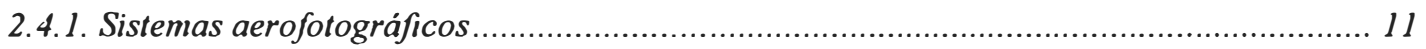

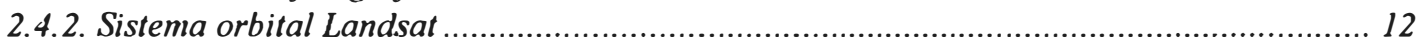

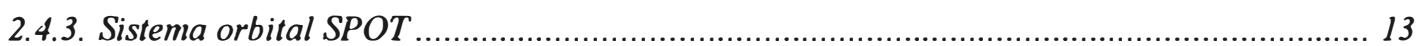

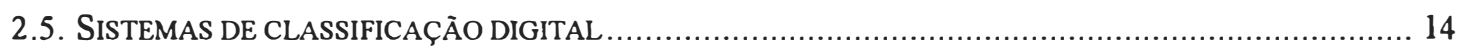

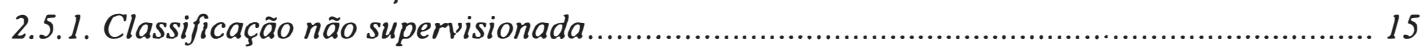

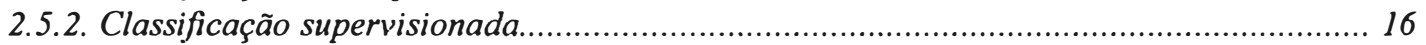

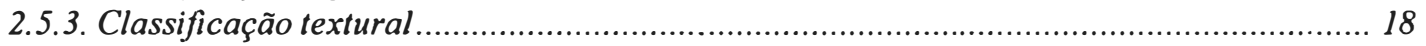

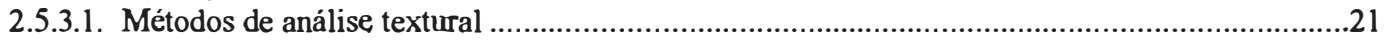

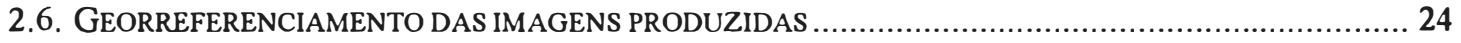

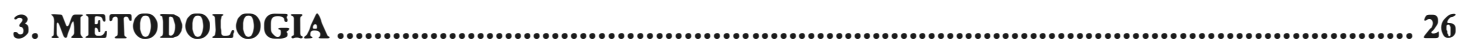

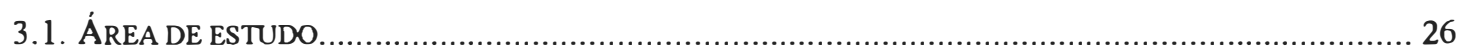

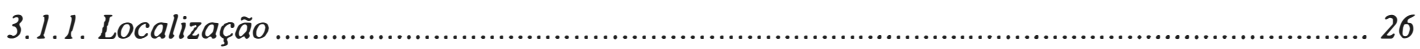

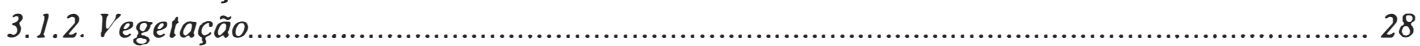

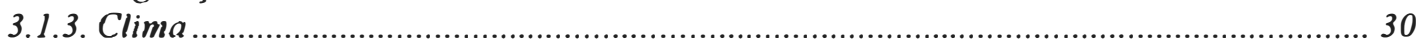

3.2. IDENTIFICAÇÃO E ZONEAMENTO DAS UNIDADES ECOLÓGICAS POR MEIO DE FOTOGRAFIAS AÉREAS E

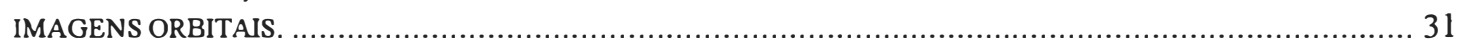

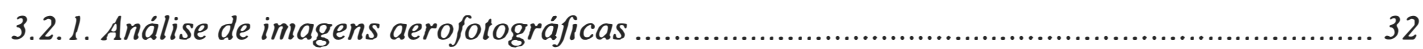

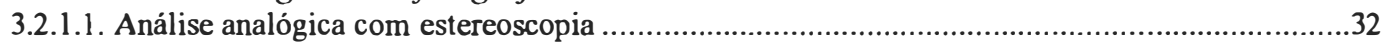

3.2.1.2. Análise analógica de fotografia aérea em formato digital.........................................................3

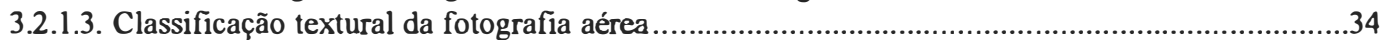

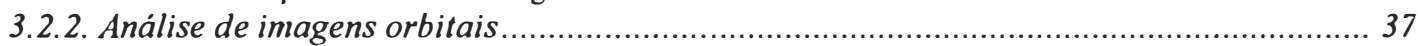

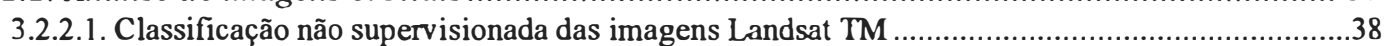

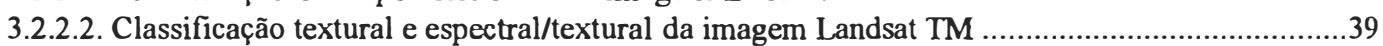

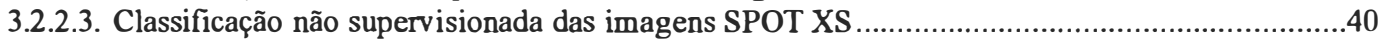

3.2.2.4. Classificação textural e espectral/textural da imagem SPOT ....................................................41

3.3. GEORREFERENCIAMENTO DAS IMLAGENS E LOCALIZAÇÃO DAS UNIDADES ECOLÓGICAS ...............41

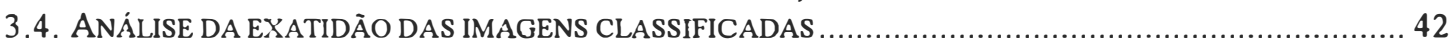

3.5. CHECAGEM PRÉVIA DAS UNIDADES ECOLÓGICAS NO CAMPO E CARACTERIZAÇÃO FLORISTICA, FISIONÔMICA E ESTRUTURAL DESSAS UNIDADES IDENTIFICADAS NAS CLASSIFICAÇÕES DAS IMAGENS. . 45 3.6. ANÁLISE DE SIMILARIDADE FLORISTICA ENTRE AS UNIDADES AMOSTRAIS DAS UNIDADES ECOLÓGICAS

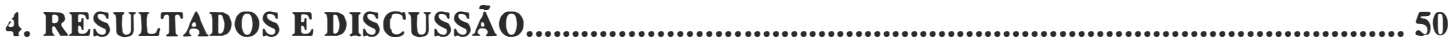

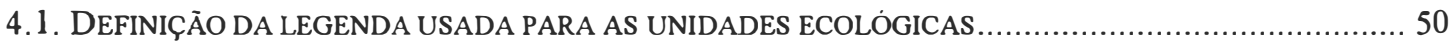




\section{Página}

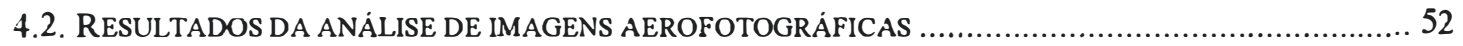

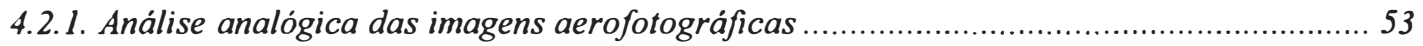

4.2.2. Análise visual de fotografia aérea em formato digital................................................ 57

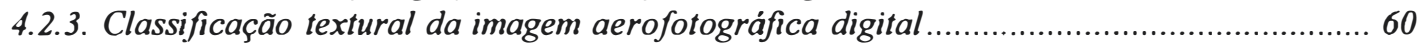

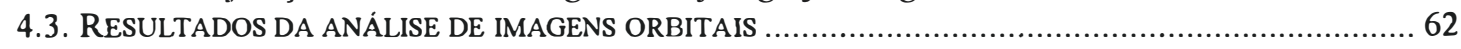

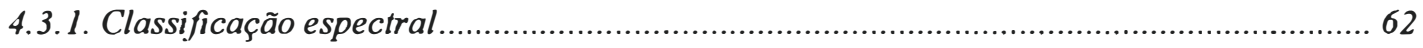

4.3.2. Classificação textural e espectral/textural das imagens Landsat e SPOT ......................... 66

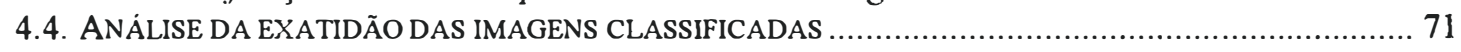

4.5. COMPARAÇÃO ENTRE OS MÉTODOS DE CLASSIFICAÇÃO DE IMAGENS ……................................ 79

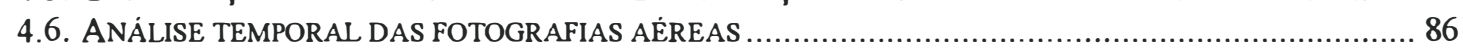

4.7. CARACTERIZAÇÃO E COMPARAÇÃO FLORISTICA. FISIONÔMICA E ESTRUTURAL DAS UNIDADES

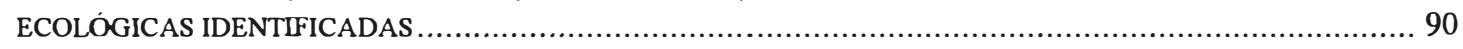

4.7.1. Caracterização florística da Reserva Municipal de Santa Genebra, considerando todas as

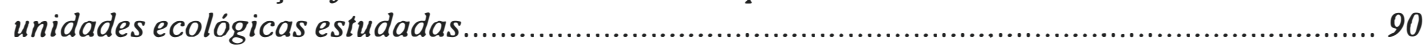

4. 7.2. Caracterização florística, fisionômica e estrutural de cada unidade ecológica ................. 93

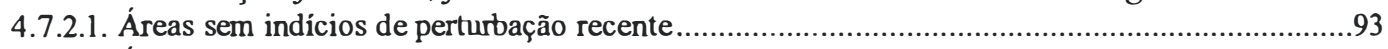

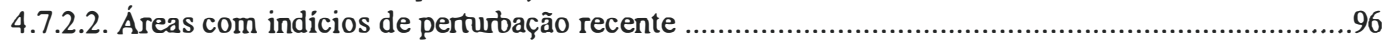

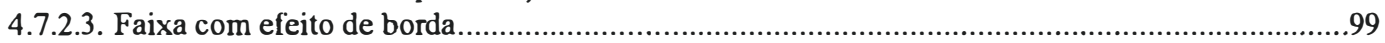

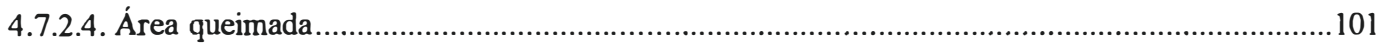

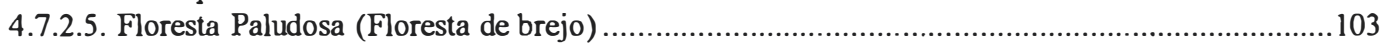

4.7.2.6. Maciço de maria-preta (Diatenopteryx sorbifolia Radlk.) .....................................................106

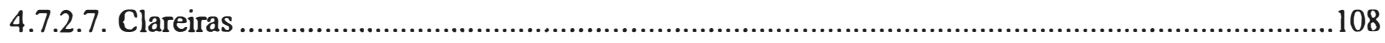

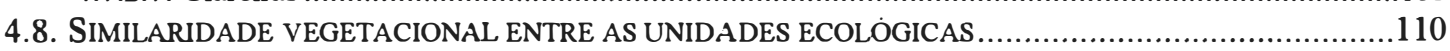

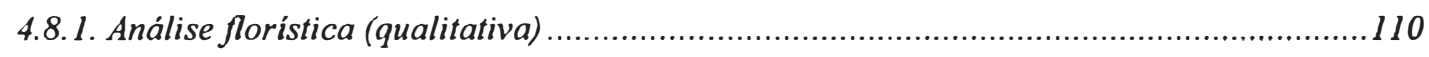

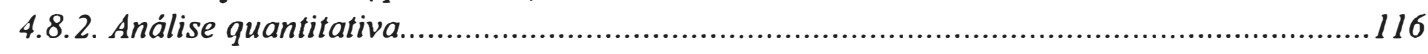

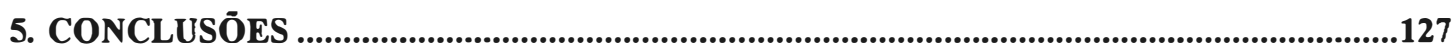

ANEXO A

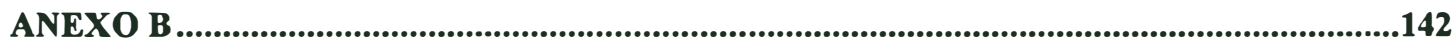

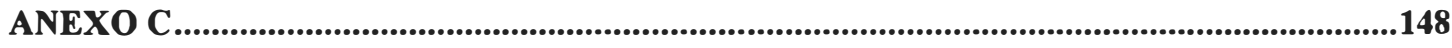

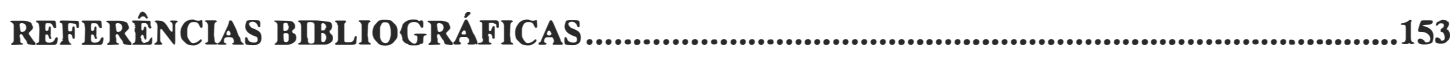




\title{
DETERMINAÇÃO DE UNIDADES ECOLÓGICAS NUM FRAGMENTO DE FLORESTA NATIVA, COM AUXÍLIO DE SENSORIAMENTO REMOTO
}

\author{
Autor: ANDRÉ GUSTAVO NAVE \\ Orientador: Prof. Dr. RICARDO RIBEIRO RODRIGUES
}

\section{RESUMO}

Atualmente existe uma grande necessidade de se desenvolver metodologias de trabalho que permitam a identificação e checagem do mosaico florestal. As análises realizadas por meio de fotografias aéreas ou imagens orbitais podem viabilizar, com baixo custo, a identificação, quantificação e evolução das unidades ecológicas no mosaico florestal, permitindo adequação das propostas de caracterização e manejo dos fragmentos florestais. Objetivando o teste de algumas metodologias para o zoneamento e a identificação das diferentes unidades ecológicas florestais (naturais e sucessionais) da Reserva Municipal de Santa Genebra no município de Campinas ,SP, foram usados métodos de interpretação de fotografias aéreas e processamentos de imagens orbitais Landsat TM e SPOT XS. A comprovação da existência das unidades ecológicas identificadas nas análises das imagens foi realizada através das caracterizações fisionômicas, florísticas e estruturais dessas unidades, obtidas através de levantamentos expeditos de campo. Para a avaliação da similaridade entre as comunidades de cada unidade ecológica identificada, foram realizadas análises de similaridade com base nos dados obtidos na caracterização florística e estrutural de cada unidade, confirmando as particularidades vegetacionais dessas unidades. A comparação dos mapas produzidos pelas análises das fotografias aéreas e imagens orbitais foi realizada de acordo com o número de unidades ecológicas identificadas, nível de detalhamento da verdade terrestre, 
tempo de análise de imagem, recursos técnicos necessários, disponibilidade da imagem, resolução temporal da imagem, freqüência de uso em trabalhos de vegetação e custo de aquisição, entre outros. A obtenção da exatidão dos mapas produzidos foi realizada através da geração de matrizes de erro, calculando a exatidão global e individual (erros de comissão e omissão), desempenho médio e os coeficientes de concordância Kappa global e individual. Os resultados deste trabalho mostraram que o método de análise analógica de fotografias aéreas utilizando a estereoscopia foi mais adequado e quanto maior a escala, melhor é a identificação das unidades ecológicas e o nível de detalhamento do mapa. Nas análises de imagens orbitais, a classificação não supervisionada, que é uma das técnicas mais simples em termos de processamento de imagens, obteve o melhor resultado na identificação do mosaico florestal, principalmente a variação do gradiente sucessional. Os resultados obtidos pelos classificadores texturais nas classificações em fotografia aérea e em imagens orbitais foram insatisfatórios no reconhecimento das unidades. A utilização das análises de agrupamento e de ordenação mostraram-se eficientes para determinação da similaridade entre as comunidades estudadas, confirmando a existências das unidades no campo. A análise de imagens de diferentes idades mostrou-se um eficiente instrumento de monitoramento ambiental com baixo custo, subsidiando a adoção de práticas diferenciadas de conservação e manejo de remanescentes florestais. A identificação do mosaico ambiental possibilita ainda uma melhor definição de áreas de amostragem em fragmentos. 


\title{
FRAGMENT OF NATIVE FOREST USING REMOTE SENSING
}

\author{
Author: ANDRÉ GUSTAVO NAVE \\ Adviser: Prof. Dr. RICARDO RIBEIRO RODRIGUES
}

\section{SUMMARY}

Nowadays, there is a great necessity of developing work methodologies that allow the identification and checking of the forest mosaic. The analyses made by aerial photographs or orbital images can make possible, with low cost, the identification, quantification and evolution studies of the ecological units in the forest mosaic, allowing adaptation of the characterization proposals and management of the forest fragments. The objective of this work was to test some methodologies for the zoning and the identification of the different forest ecological units (natural and sucessional) of Santa Genebra's Municipal Reserve in Campinas, São Paulo. Methods of interpretation of aerial photographs and processing of Landsat TM and SPOT XS orbital images were used. The confirmation of the existence of the ecological units identified in the image analyses was obtained in field expedite survey, by physiognomic, floristic and structure characterization of those units. For the evaluation of the similarity among the communities of each identified ecological unit, similarity analyses based on the data obtained in the floristic and structural characterization of each unit were carried out, confirming the vegetacional particularities of these units. The comparison of the maps produced by the analyses of the aerial photographs and orbital images was made according to the number of identified ecological units, detailed ground truth, time spent in image analysis, necessary technical resources, image availability, image temporal resolution, use frequency in vegetation works and acquisition cost, among others. The accuracy of the produced maps was obtained generating error matrices, calculating the 
global and individual accuracy (commission and omission errors), medium performance and the global and individual Kappa concordance coefficients. The results of this work showed that the analogical method of analysis of aerial photographs using stereoscopy was more appropriate and that the identification of the ecological units and that the larger was the scale used, better was the level of map detailing. In the analyses of orbital images, the unsupervised classification, that it is one of the easiest techniques in terms of image processing, obtained the best result in the identification of the forest mosaic, mainly the variation of the sucessional gradient. The results obtained by the textural classifiers in the classifications in aerial picture and in orbital images were unsatisfactory in the recognition of the units. The use of the grouping and ordering analyses were efficient in the determination of the similarity among the studied communities, confirming the existence of the units in the field. The analysis of images of different ages was an efficient low cost instrument of environmental monitoring, subsidizing the use of differentiated practices of conservation and management of forest remainders. The identification of the environmental mosaic also provides a better definition of sampling areas in fragments. 


\section{INTRODUÇĀO}

A literatura mostra que remanescentes florestais são muito heterogêneos em termos florísticos e estruturais, mesmo considerando trechos contínuos de floresta (Whitmore, 1975; Oldeman, 1979; Cardoso-Leite, 1995; Oliveira, 1997; Pivello et al., 1997; Bitencourt et al., 1997; Rodrigues, no prelo, etc.). Essa heterogeneidade dá origem aos chamados mosaicos florestais, que expressam a heterogeneidade ambiental ou o gradiente sucessional dentro de fragmentos florestais (Oliveira-Filho \& Ratter, 1995; Metzger et al., 1997; Rodrigues, no prelo, etc.).

O mosaico ambiental é determinado pelas condições edáficas e topográficas locais (Rodrigues, 1992; Durigan \& Leitão Filho, 1995; Jorge, 1995; Ivanauskas et al., 1997; Metzger et al., 1997; Felfili, 1998, entre outros), enquanto que o mosaico sucessional é causado tanto pela ocorrência de perturbações naturais, como a abertura de clareiras, ou pelos fatores antrópicos de degradação, como a fragmentação, o fogo, o extrativismo, o efeito de borda, entre outros (Lima, 1989; Jorge, 1995; Oliveira, 1997, etc.).

A comparação entre os levantamentos realizados em fragmentos de florestas estacionais semideciduais do Estado de São Paulo (Nave, 1994; Morellato \& Leitão Filho, 1995; Salis et al., 1995 e Rodrigues, no prelo e outros), num total aproximado de 38 trabalhos já realizados, mostra em geral grande heterogeneidade florística e estrutural entre as unidades amostradas nesses fragmentos, principalmente no que se refere aos parâmetros quantitativos das espécies.

Segundo Rodrigues (no prelo), essa heterogeneidade entre amostras de florestas já foi amplamente discutida na literatura e as causas principais dessa variação poderiam ser agrupadas em três categorias: 1- características históricas de perturbação do remanescente 
florestal, influenciando as taxas de extinção local, de sucesso no estabelecimento e na sobrevivência de espécies, tais como, variações climáticas de ciclo longo, tipos e freqüências de perturbações naturais e antrópicas, tamanho e grau de isolamento das formações estudadas; 2- características abióticas locais, tais como, variáveis edáficas, topografia, microclima, poluição, ocorrência e freqüência de alagamentos; 3características intrínsecas da comunidade vegetal em questão, que resultam em variações no recrutamento, crescimento e sobrevivência de populações, nas interações entre espécies, nas características reprodutivas de espécies e outros.

A importância de cada uma dessas características na definição florística e estrutural da vegetação varia de fragmento para fragmento, sendo que cada um vai se constituir numa combinação própria que resulta em características vegetacionais também próprias. Entretanto, deve ser ressaltado, que as características vegetacionais típicas de cada trecho do fragmento têm caráter dinâmico, variando no tempo de acordo com as alterações das condições ambientais e sucessionais (Oliveira-Filho \& Ratter, 1995; Ivanauskas et al., 1997; Metzger et al., 1997; Felfili, 1998, etc.).

Nas últimas décadas, o mosaico florestal das diversas formações naturais tem sido incrementado pela ação antrópica, principalmente o extrativismo seletivo e as queimadas que atuam de forma diferenciada nos vários trechos da floresta. Essa devastação florestal chegou até mesmo em áreas de dificil acesso, tornando-se raros os fragmentos remanescentes ainda bem conservados (Hueck, 1972; Rodrigues, 1992; Rozza, 1997, entre outros). Essa acelerada degradação tem direcionado muitos estudos no sentido de acumular conhecimentos sobre a flora, a estrutura e a dinâmica desses ambientes historicamente perturbados pela ação antrópica.

Entretanto, a metodologia de amostragem que tem sido usada para a maioria dos trabalhos de florística e fitossociologia de florestas do Estado de São Paulo, não foi definida com o objetivo de identificação, quantificação e caracterização da heterogeneidade existente dentro de um fragmento, muito menos para elucidar suas variações temporais. Como a composição de unidades ecológicas dentro de um fragmento depende do trecho florestal amostrado, os resultados florísticos e estruturais 
desse trecho apresentarão diferenças quando comparados com outros trechos desse ou mesmo de fragmentos distintos.

Dessa forma, com a metodologia que vem sendo usada, as diferenças de resultados entre os trabalhos deveria ser esperada, sendo menor nos fragmentos com características semelhantes, em termos ecológicos e de perturbação (Rodrigues, no prelo).

Apesar disso, ainda são poucos e recentes os trabalhos com florestas tropicais, que associam a composição florística e fitossociológica da comunidade, com os fatores ecológicos que poderiam estar interferindo na ocorrência e distribuição das espécies, bem como os trabalhos de autoecologia das espécies nativas, que certamente contribuirão muito para o entendimento dessa heterogeneidade e dos processos ecológicos envolvidos (Gandolfi, 1999).

Os métodos que viabilizam a identificação prévia do mosaico florestal permitem uma adequação da escolha de áreas de amostragem em trabalhos de ecologia da paisagem, de comunidades e de populações, inclusive orientando a discussão sobre as causas dessa heterogeneidade vegetacional e principalmente auxiliando na adoção de práticas diferenciadas de manejo de cada trecho do fragmento (unidades ecológicas), em função de suas características intrínsecas, garantindo o sucesso e a economicidade dessas práticas. Se esses recursos forem ignorados, a identificação e caracterização do mosaico florestal terá de ser realizada exclusivamente com trabalhos de campo, onerando significativamente os custos dessa atividade.

Dessa forma, existe hoje uma grande necessidade de se desenvolver metodologias de trabalho que permitam a identificação e checagem do mosaico florestal nesses fragmentos. As análises realizadas por meio de imagens aéreas ou orbitais podem viabilizar, com baixo custo, a identificação e quantificação das unidades ecológicas com fisionomia semelhante no mosaico florestal (Scott et al., 1993) e permitir um aumento de conhecimento sobre a complexidade da dinâmica florestal, fornecendo dados de extrema importância no esclarecimento sobre o estado degradativo da floresta, capaz de auxiliar muito a adoção de práticas de conservação e manejo. 
Dentro desse contexto, o objetivo desse trabalho foi a avaliação de metodologias que permitam realizar o zoneamento das diferentes unidades ecológicas (naturais e sucessionais) em uma área contínua de floresta, usando como ferramenta, a interpretação de fotografias aéreas e imagens orbitais Landsat TM e SPOT XS.

A comparação dos mapas produzidos pelas análises das fotografias aéreas e imagens orbitais foi realizada de acordo com o número de unidades ecológicas identificadas, nível de detalhamento da verdade terrestre, matrizes de erro, análise Kappa, tempo de análise de imagem, recursos técnicos necessários, disponibilidade da imagem, resolução temporal da imagem, freqüência de uso em trabalhos de vegetação e custo de aquisição, entre outros.

Com os resultados desse trabalho espera-se realçar a importância do zoneamento das unidades ecológicas em fragmentos florestais, possibilitando a definição de práticas diferenciadas de manejo e conservação dessas áreas. Além disso, o conhecimento do mosaico ambiental possibilita uma melhor definição de áreas de amostragem em fragmentos remanescentes. 


\section{REVISĀO DE LITERATURA}

\subsection{Situação da vegetação natural na região de Campinas}

A acelerada degradação das formações florestais do Estado de São Paulo nas últimas décadas já foi mostrada por diversos autores, dos quais destacamos os trabalhos de Hueck (1972), Troppmair (1969), Victor (1975), Reichmann Neto (1978), Consema (1985) e Kronka (1993). A expansão da fronteira agrícola, associada mais recentemente, ao crescimento urbano, foram os principais responsáveis por essa degradação.

Essas modificações, com conseqüente degradação das formações naturais no Estado, foram de tamanha proporção, que hoje restam apenas pequenos fragmentos de vegetação natural. Segundo Victor (1975), esses remanescentes somam em torno de 8\% da superficie do Estado, sendo que antes da ocupação antrópica a cobertura original era de $82 \%$. O programa Olho Verde, que fez um levantamento da cobertura vegetal do Estado, por meio de satélite (Landsat TM), concluiu que restam ainda $13,68 \%$ de vegetação natural. Esses fragmentos, quando em posse de particulares, geralmente se apresentam em avançado estágio de perturbação, ainda sofrendo interferências antrópicas de diferentes naturezas como fogo, extrativismo seletivo, uso dessas áreas para pastagem etc.

Estudos atuais estão concluindo que o histórico de perturbação antrópica dos remanescentes florestais, pode ter importância equivalente ou ainda maior, na degradação dessas áreas, que o simples isolamento desses fragmentos (Rozza, 1997).

No entanto, Matthes (1991), Rodrigues (1992), Bernacci (1992) e Castellani \& Stubblebine (1993) confirmam, através de estudos realizados no município de Campinas, que a fragmentação condiciona, mesmo em remanescentes florestais maiores, que foram 
apenas recentemente protegidos, a necessidade de práticas adequadas de manejo voltadas para a manutenção da biodiversidade dessas formações, que são variáveis em função de alguns fatores como tamanho, áreas circunvizinhas, proximidade de outras formações naturais e outros.

A região de Campinas apresentou-se no trabalho de Kronka (1993), como uma das áreas mais devastadas do Estado de São Paulo. A situação encontrada para a cobertura vegetal natural foi de apenas $3 \%$ da sua superficie, constituída basicamente de pequenos remanescentes florestais fragmentados. Nesse valor estão incluídos fragmentos florestais distribuídos por todo o município, sendo que a maior concentração deles ocorre na região leste do município. Os mais representativos em termos de área foram: a Reserva Municipal de Santa Genebra, com 252 ha à oeste do município; a mata do Ribeirão Cachoeira, com 210 ha na região norte; a mata da Fazenda São Vicente, com 70 ha no centro leste do município; o Parque Estadual do Ara, com 64 ha à sudeste do município; e a mata da Fazenda da Glória, com 150 ha na região nordeste do município.

Segundo Rodrigues (1992), outros remanescentes também se destacam pela sua importância para o lazer e educação ambiental da população (Bosque do Jequitibás, Bosque dos Alemães, Parque Ecológico Monsenhor Emílio José Salim, entre outros), para pesquisa (Reserva Municipal da Santa Genebra, fragmentos da fazenda Santa Elisa IAC) e mesmo pelo fato de serem remanescentes de formações naturais pouco representadas no município, como os remanescentes de mata de brejo do oeste e sul do município e também as pequenas manchas de cerrado encontradas nos limites com os municipios de Sumaré, Paulinia, Indaiatuba, Monte Mor e Itapeva.

Os poucos remanescentes ainda florestados estão em sua maioria protegidos pelo Estado e necessitam urgentemente de um plano de conservação, manejo e recuperação, que garantam a conservação desses fragmentos (Rodrigues, 1992; Morellato \& Leitão Filho, 1995).

A adoção de técnicas de manejo e recuperação dos fragmentos florestais depende ainda do conhecimento da dinâmica florestal, que por sua vez apresenta particularidades 
para cada trecho da floresta, dependendo das características ambientais e do histórico de perturbação natural ou antrópico daquela situação.

\subsection{O mosaico florestal}

Nas duas últimas décadas tivemos um aumento significativo nos estudos relacionados à composição florística e à estrutura fitossociológica das florestas estacionais semideciduais que ocorrem na forma de fragmentos no interior do Estado de São Paulo (Martins, 1979; Matthes, 1980; Bertoni, 1984; Struffaldi-De-Vuono, 1985; Rodrigues, 1986; Tamashiro et al., 1986; Pagano et al., 1987; Rossi, 1987; Baitello et al., 1988; César, 1988; Bertoni et al., 1988; Torres, 1989; Catharino, 1989a; Silva, 1989; Pinto, 1989; Vieira, 1989; Salis, 1990; Nicolini, 1990; Cavassan \& Martins, 1990; Grombone et al., 1990; Gabriel, 1990; Morellato, 1991; Pastore et al., 1992; Baitello et al., 1992; Nastri et al., 1992; Rozza et al., 1992; Toledo Filho et al., 1993; Kotchekoffhenriques, 1994; Ivanauskas et al., 1997; Cardoso-Leite, 1995; Gandolfi et al., 1995 e outros). Entretanto, a maioria desses trabalhos, com algumas exceções (Bertoni, 1984; Bernacci, 1992; Rodrigues, 1992; Cardoso-Leite, 1995; Gandolfi et al., 1995), não relacionaram diretamente os dados da estrutura da vegetação, com a dinâmica sucessional da floresta e, com exceção de Cardoso-Leite (1995) e Oliveira (1997), nenhum fez o zoneamento das unidades ecológicas ocorrentes no trecho de floresta estudado.

Um dos primeiros trabalhos em florestas tropicais sobre o mosaico florestal foi realizado por Whitmore (1975), que adaptou o modelo de mosaico sucessional proposto por Watt (1947) em florestas temperadas e dividiu, com base em estudos florísticos e estruturais, o desenvolvimento florestal em três fases: de clareira; de construção; e de maturidade.

Oldeman (1979), baseado em estudos de espécies florestais, comparou a relação entre a altura total e o diâmetro da base do tronco e constatou que as árvores em crescimento inicial apresentam esta relação próxima de 100. Nas árvores em estado maduro, esta relação cai para menos de 100 e nos indivíduos arbóreos senescentes esta 
relação é muito menor que 100 . Com base neste estudo o autor propôs que o desenvolvimento da floresta ocorre seguindo mudanças arquiteturais dos indivíduos arbóreos e considera a floresta como um "mosaico" silvático composto de "ecounidades".

Seguindo esse modelo arquitetural, Oldeman (1979) definiu quatro tipos de ecounidades que vão constituir o mosaico florestal: as "ecounidades em reorganização", que representam as clareiras recentemente abertas através do tombamento das árvores de grande porte, permitindo a entrada de luz direta; as "ecounidades em desenvolvimento", que representam os indivíduos arbóreos jovens, com copa estreita e alongada no sentido vertical e um tronco principal apresentando crescimento monopodial; as "ecounidades em equilíbrio", que representam os indivíduos arbóreos que atingiram seu crescimento máximo em altura e com copa ramificada, ampla, geralmente constituindo o dossel superior; as "ecounidades em degradação", que são constituídas de indivíduos velhos senescentes, mortos em pé ou com danos irreparáveis.

Atualmente, o zoneamento do mosaico florestal é feito geralmente de duas maneiras: uma usando apenas a interpretação das imagens aerofotográficas ou orbitais, sem uma checagem de campo; ou o inverso, onde os levantamentos de apenas alguns trechos desses remanescentes não caracterizam e não promovem o zoneamento da vegetação. Esses levantamentos não permitem a extrapolação dos resultados para todo o fragmento e, portanto, sem sustentar qualquer proposta de manejo.

Recentemente, vários trabalhos usando sensoriamento remoto vêm sendo desenvolvidos e demonstrando a dinâmica desses mosaicos em remanescentes naturais. (Mausel et al., 1993; Moran et al., 1994; Pivello et al., 1997 e Bitencourt et al., 1997). No entanto, esses trabalhos geralmente baseiam-se apenas em claras diferenciações fisionômicas da vegetação, sem considerar os seus aspectos florísticos ou estruturais.

Outro problema refere-se as metodologias usadas na interpretação de imagens orbitais que, dependendo do tipo de análise e do tamanho dos fragmentos considerados, podem apresentar resultados muito discrepantes entre os diferentes métodos e destes com a realidade de campo. Esses resultados divergentes são oriundos, na maioria das vezes, da 
inexperiência no uso de metodologias de interpretação, principalmente quando se trata de fragmentos florestais de tamanho reduzido.

Os trabalhos analógicos usando imagens de satélite em escalas de 1:50.000 ou menores, têm obtido bons resultados na identificação das grandes e distintas unidades fitogeográficas. No entanto, essas escalas não permitem identificação do mosaico florestal dentro de cada fragmento florestal, inviabilizando qualquer tentativa de recomendações de práticas diferenciadas e adequadas de manejo e conservação desses remanescentes. Para os fragmentos menores, que inclusive representam a grande maioria das florestas remanescentes do Estado, a escala que tem sido usada muitas vezes nem reconhece o próprio fragmento, quanto mais a sua composição de unidades ecológicas (Kronka, 1993).

Apesar disso, o zoneamento prévio de fragmentos florestais utilizando fotografias aéreas e imagens orbitais, tem sido visto como uma metodologia muito promissora no auxílio em trabalhos com vegetação (Scott et al., 1993), principalmente no que diz respeito ao planejamento metodológico mais adequado desses levantamentos e a quantidade de informações necessárias para as conclusões do referido trabalho. No entanto, pouco se fez ainda sobre a metodologia de checagem e caracterização das unidades ecológicas, identificadas no mosaico de remanescentes florestais do interior do Estado.

Existe ainda a possibilidade de um acompanhamento temporal do mosaico desses remanescentes, através da análise periódica principalmente de imagens orbitais (Mausel et al., 1993; Moran et al., 1994). Isso se justifica pelas constantes perturbações a que essas formações naturais estão submetidas, como resultado das ações antrópicas, principalmente as ações de extrativismo seletivo e ocorrência de fogo nos remanescentes naturais. Entretanto, a atualização periódica destas informações, através de trabalhos de campo, é onerosa, demorada e muitas vezes imprópria para fornecer dados que sustentem ações em escala menores (Chen, 1996). 


\subsection{Definição de sensoriamento remoto}

Segundo Shimabukuro (1996), a acepção original da palavra sensoriamento remoto, referia-se simplesmente à observação e à medida de um objeto sem tocá-lo. Com o avanço tecnológico o conceito passou a abranger toda uma disciplina, sendo aplicado com várias definições como: "é a ciência e a arte de se obterem informações sobre um objeto, área ou fenômeno, através da análise de dados coletados por aparelhos denominados sensores, que não entram em contato direto com os alvos em estudo" (Crepani, 1983); "técnica de coletar informações à distância" (Aronoff, 1989); "ciência ou arte de obter informações sobre um objeto, área ou fenômeno, através da análise de dados adquiridos por um equipamento que não está em contato com o objeto, área ou fenômeno sob investigação (Lillesand \& Kiefer, 1994); "sensoriamento remoto é a técnica de coleta de informação a distância, com o objetivo de estudar o ambiente terrestre através do registro e da análise das interações entre a radiação eletromagnéticas e as substâncias componentes da terra em suas mais diversas manifestações, utilizando de sensores, equipamento para processamento e transmissão de dados, aeronaves etc." (Novo, 1989).

Maiores detalhes sobre a evolução do sensoriamento remoto podem ser encontradas nos trabalhos de Novo (1989), Vettorazzi (1992) e Shimabukuro (1996).

\subsection{Sistemas sensores}

Segundo Novo (1989), um sensor é definido como um equipamento capaz de transformar alguma forma de energia em sinal passível de ser convertido em informação sobre o meio ambiente, sendo que no caso do Sensoriamento Remoto, a energia utilizada é a radiação eletromagnética.

Os sensores podem ser classificados como imageadores, quando fornecem uma imagem da superficie observada, fornecendo informações sobre a variação espacial da 
resposta espectral; e não imageadores, quando o produto final é apresentado na forma de valores numéricos ou então gráficos (Novo, 1989 e Vettorazzi, 1992).

Segundos esses mesmos autores, os sensores podem ainda ser classificados em dois tipos, os ativos e os passivos. Os sensores ativos são aqueles que produzem energia própria de radiação como por exemplo os radares, enquanto que os passivos detectam a radiação refletida ou emitida pelos objetos, dependendo portanto, de uma fonte de energia externa, como por exemplo o sol. As máquinas fotográficas são bons exemplos desse tipo de sensor.

Na década de 60, o grande número de possibilidades de trabalho gerado pelas plataformas espaciais estimulou os pesquisadores e principalmente os militares, a desenvolverem as áreas da ótica, eletrônica, telecomunicações e tratamento de informações. Esse interesse fez com que fosse suscitado até hoje o desenvolvimento de uma nova área do conhecimento e da tecnologia com uma gama de aplicações teóricas e práticas sempre crescente (Shimabukuro, 1996).

\subsubsection{Sistemas aerofotográficos}

Segundo Lillesand \& Kiefer (1994), as fotografias aéreas tiradas de balão, da cidade de Bievre na França no ano de 1858, por Gaspard Felix Tournachon, deram início ao sensoriamento remoto. No entanto, as técnicas de fotointerpretação eram conhecidas apenas por fotogrametria, sendo que a partir do advento da era espacial e das construções de satélites na década de 60, surgiu o termo sensoriamento remoto (Shimabukuro, 1996). Durante esse período, as fotografias aéreas foram largamente utilizadas na identificação e mapeamento de áreas de interesse, auxiliando muito nos estudos ambientais.

Apesar do grande avanço tecnológico dos sensores orbitais, cujas imagens são obtidas em ampla faixa do espectro e podem ser processadas automaticamente, os sistemas fotográficos ainda possuem um indiscutivel valor para aquisição dos dados de sensoriamento remoto (Steffen et al., 1981). Grande parte desse valor deve-se ao poder de resolução espacial desses sensores. 
As fotografias aéreas são obtidas através de câmaras especiais chamadas câmaras fotográficas aéreas, que permitem um maior controle das distorções espaciais e radiométricas normalmente obtidas em outros tipos de câmaras (Novo, 1989).

De modo geral, as fotografias são obtidas no modo pancromático, ou seja, o registro da radiação provém de uma única faixa do espectro eletromagnético que compreende o visível e suas proximidades, apresentando uma aparência mais natural.

Outra forma de obtenção de aerofotografias é o modo multiespectral. Esse modo é mais raramente utilizado e as imagens são obtidas através da utilização simultânea de várias câmaras utilizando filmes e filtros ou com uma única câmara, com várias objetivas, cada uma com um filtro diferente e um único filme (Crepani, 1983).

\subsubsection{Sistema orbital Landsat}

Esse sistema teve inicialmente o nome de Earth Resources Technology Satellite 1 (ERST - 1) quando foi lançado em julho de 1972, passando a ser chamado de Landsat em janeiro de 1975 com o lançamento do segundo satélite (Novo, 1989; Vettorazzi, 1992). Posteriormente, foram lançados mais três satélites da série, sendo o Landsat-3 em março de 1978, o Landsat-4 em julho de 1982 e o Landsat-5 em março de 1984, que foram suprindo a perda de eficiência dos satélites precedentes e incorporando novos avanços tecnológicos, tanto na plataforma, como nos sensores (Lillesand \& Kiefer, 1994).

Segundo Shimabukuro (1996), a partir do Landsat 4, além do sensor "Multispectral Scanner" (MSS), foi adicionado ao satélite um novo e aperfeiçoado sistema de coleta de informação chamado "Thematic Mapper" (TM). Os dois sensores são passivos, dependendo de uma fonte de radiação externa para viabilizar o registro das imagens. As principais características desses sensores são apresentadas na Tabela 1.

Dentre todos os sistemas orbitais de sensoriamento remoto hoje em operação, o sistema Landsat da NASA (National Aeronautics and Space Administration), tem sido até o momento o mais importante e o mais utilizado para as condições brasileiras, 
principalmente devido às facilidades físicas e orçamentárias para aquisição dos produtos produzidos por esse sensor. Essa facilidade deve-se à recepção das imagens que é feita em Cuiabá, MT (desde 1973); o processamento eletrônico e fotográfico de imagens em Cachoeira Paulista, SP; e o sistema de distribuição nacional de imagens (Novo, 1989; Shimabukuro, 1996).

Tabela 1- Principais características das imagens MSS e TM do Landsat-5.

\begin{tabular}{|c|c|c|}
\hline $\begin{array}{l}\text { Características do } \\
\text { sensor }\end{array}$ & MSS & TM \\
\hline $\begin{array}{l}\text { Resolução } \\
\text { espectral }\end{array}$ & 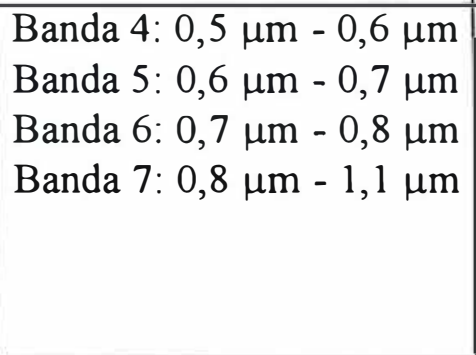 & 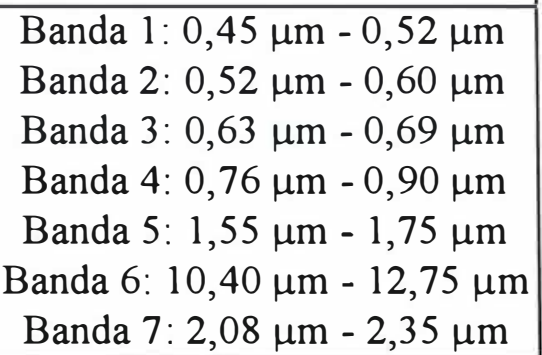 \\
\hline Resolução espacial & $79 \mathrm{~m} \times 79 \mathrm{~m}$ & $\begin{array}{c}30 \mathrm{~m} \text { (banda } 1 \text { a } 5 \text { e } 7) \\
120 \mathrm{~m} \text { (banda } 6)\end{array}$ \\
\hline Resolução radiométrica & 128 níveis de cinza & 256 níveis de cinza \\
\hline Dimensão da imagem & $185 \mathrm{~km} \times 185 \mathrm{~km}$ & $185 \mathrm{~km} \times 185 \mathrm{~km}$ \\
\hline $\begin{array}{l}\mathrm{N}^{\circ} \text { de pixels por } \\
\text { imagem }\end{array}$ & 7.722 .000 & 38.020 .000 \\
\hline Resolução temporal & 16 dias & 16 dias \\
\hline
\end{tabular}

Fonte: Vettorazzi (1992)

\subsubsection{Sistema orbital SPOT}

O sistema SPOT (Sistème Probatoire d' Observation de la Terre) foi desenvolvido e projetado pelo CNES (Centre National d'Etudes Spatiales) na França, a partir de 1978, com a participação da Suécia (6\%) e Bélgica (4\%), tendo sido lançado o primeiro satélite em fevereiro de 1986 (Novo, 1989; Vettorazzi, 1992).

O SPOT possui a bordo dois sensores de alta resolução (HRV - Haute Resolution Visible) com capacidade de imageamento oblíquo ("off-nadir"), que possibilita os sistema aumentar a repetividade de cobertura, além da possibilidade de obtenção de pares 
estereoscópicos das imagens. Essas são as principais características, que diferenciam o sistema SPOT do sistema Landsat.

O sistema fornece dados multiespectrais e pancromáticos com resolução de $20 \mathrm{~m}$ e $10 \mathrm{~m}$, respectivamente, sendo que o modo multiespectral (XS) apresenta três bandas espectrais e o modo pancromático (PAN), uma única banda espectral (Pereira et al., 1989). As características desses dois sensores são apresentadas na Tabela 2.

Novo (1989) chama a atenção sobre o compromisso entre a resolução espectral e a resolução espacial. Dentro deste contexto, a autora ressalta que o sensor HRV do SPOT possui apenas três faixas (bandas) espectrais, enquanto que o TM do Landsat possui sete faixas, deixando a dúvida de que a resolução espacial de $20 \mathrm{~m}$ do HRV poderá compensar a perda de informação espectral, resultante da diminuição do número de bandas.

Tabela 2- Principais características das 1magens multiespectrais e pancromáticas do SPOT.

\begin{tabular}{|l|c|c|}
\hline Características do sensor & Modo Multiespectral (XS) & $\begin{array}{c}\text { Modo Pancromático } \\
\text { (PAN) }\end{array}$ \\
\hline $\begin{array}{l}\text { Resolução } \\
\text { espectral }\end{array}$ & $\begin{array}{c}\text { Banda 1: } 0,50 \mu \mathrm{m}-0,59 \mu \mathrm{m} \\
\text { Banda 2: } 0,61 \mu \mathrm{m}-0,68 \mu \mathrm{m} \\
\text { Banda 3: } 0,79 \mu \mathrm{m}-0,89 \mu \mathrm{m}\end{array}$ & $0,51 \mu \mathrm{m}-0,73 \mu \mathrm{m}$ \\
\hline Campo de visada & $4,13^{\circ}$ & $4,13^{\circ}$ \\
\hline $\begin{array}{l}\text { Resolução espacial (visada } \\
\text { vertical) }\end{array}$ & $20 \mathrm{~m} \times 20 \mathrm{~m}$ & $10 \mathrm{~m} \mathrm{\times} \mathrm{10} \mathrm{m}$ \\
\hline Largura da faixa do terreno & $60 \mathrm{~km}$ & $60 \mathrm{~km}$ \\
\hline $\mathrm{N}^{\circ}$ de pixels por linha & 3.000 & 6.000 \\
\hline Resolução temporal & 26 dias & 26 dias \\
\hline
\end{tabular}

\subsection{Sistemas de classificação digital}

Os sistemas de classificação digital são técnicas que, através de processos de decisões estatísticas, permitem atribuir classes a um conjunto de pixels. Segundo Novo (1989), essas técnicas têm como objetivo, tornar o processo de mapeamento ou 
reconhecimento das características da superficie da terra menos subjetivo e com maior potencial de repetição em situações subseqüentes. Essa distinção e identificação só é possível pelo fato dos materiais superficiais apresentarem-se com comportamentos específicos e próprios ao longo do espectro eletromagnético (Crosta, 1992).

Conforme esse mesmo autor, a classificação automática de imagens multiespectrais de sensoriamento remoto diz respeito à associar cada pixel da imagem a um "rótulo", descrevendo um objeto real, sendo que quando essa operação é efetuada para todos os pixels de uma determinada área, o resultado é um mapa temático, mostrando a distribuição geográfica de um tema (vegetação, solo etc.).

Entre os sistemas de classificação digital mais conhecidos e mais utilizados podemos citar o fatiamento de níveis ("level slicing"), a classificação supervisionada e a não supervisionada, sendo que mais recentemente outras abordagens que utilizam classificadores texturais e segmentadores vêm sendo cada vez mais utilizadas, com a introdução de sensores de resolução espacial.

Revisões mais detalhadas sobre os sistemas de classificações digitais podem ser encontradas nos trabalhos de Chen (1996) e Shimabukuro (1996). Portanto, as descrições dos tipos de classificações que serão feitas a seguir, apenas se referem àquelas que são utilizadas neste trabalho, com exceção da classificação supervisionada pois, apesar da sua não utilização neste trabalho, foi necessária uma revisão que pudesse justificar o não uso desse sistema nos dados disponíveis desse trabalho.

\subsection{Classificação não supervisionada}

Esse sistema de classificação caracteriza-se pela pouca participação do operador nos processos de análise de agrupamento dos dados, sendo que a sua utilização é apropriada nos casos de pouca ou nenhuma informação detalhada sobre a distribuição dos tipos de classes da área de estudo, sendo recomendada nos casos de indisponibilidade de 
uma caracterização do tema ou como uma primeira avaliação da imagem sob análise (Novo, 1989; Shimabukuro, 1996).

$\mathrm{Na}$ classificação não supervisionada, na qual as classes são definidas estatisticamente sem a interferência do analista, ocorre a extração dos padrões de resposta espectral dominantes numa imagem, os quais são também comumente chamados de assinaturas (Pereira et al., 1989; Eastman, 1992). Esses padrões podem ser identificados como vários agrupamentos ou "nuvens" no espaço de atributos e usados como áreas de treinamento para classificação (Crósta, 1992).

Quintanilha (1990) define o treinamento como sendo a retirada de uma amostra de pixels de cada classe e o cálculo das estatísticas a elas associadas, como o vetor de médias e a matriz de variância-covariância.

Segundo Duda \& Hart (1973 citado por Shimabukuro, 1996), a primeira etapa do treinamento para os métodos de classificação não supervisionada é a utilização de um algorítmo de agrupamento como K-médias ou Isodata. Este programa identifica as concentrações naturais dos dados no espaço K-dimensional dos atributos, extraindo de cada grupo, ou "cluster", as assinaturas espectrais correspondentes a uma classe desconhecida.

O esforço de identificação destas classes é feito a posteriori, através da comparação com algum tipo de informação de referência que pode ser obtida por meio de visitas de campo, fotografias aéreas, mapas etc. Essas características de exploração da estrutura interna dos dados faz com que não haja a necessidade de um conhecimento prévio sobre a área a ser estudada.

\subsubsection{Classificação supervisionada}

Na classificação supervisionada, o analista está em constante interação com o sistema de análise de imagens digitais, necessitando de informações sobre a cena que vai servir de "treinamento" para o sistema (Novo, 1989). 
Segundo Crósta (1992), nesse tipo de classificação é necessário que o usuário tenha um mínimo de conhecimento sobre a área em estudo para dar início ao processo. $\mathrm{O}$ conhecimento sobre a área a ser classificada de preferência na mesma época de tomada da imagem, é chamado de "verdade terrestre" ("ground truth").

Essa "verdade terrestre" irá servir para o reconhecimento das "amostras de treinamento" ou "áreas de treinamento", que é delimitado de modo interativo com o software. As "amostras de treinamento" representam o "comportamento" médio das classes de interesse, sendo necessário que sejam bastante homogêneas e representativas (Novo, 1989).

Para Chen (1989), a delimitação das áreas de treinamento influi diretamente nos resultados da classificação, devendo ser coletado o maior número possível de informações a seu respeito. Hixson et al. (1980), consideram o desenvolvimento de estatísticas de treinamento, relativamente mais importante para a precisão de uma classificação do que a seleção do algorítmo de classificação.

Várias amostras de treinamento podem ser definidas para uma mesma classe, assegurando que os pixels são realmente representativos dessa classe. $\mathrm{O}$ conjunto de amostras para uma mesma classe é chamado de "conjunto de treinamento"(Crósta, 1992).

Novo (1989) ressalta que um dos problemas mais sérios na seleção de áreas de treinamento é que algumas classes de interesse não têm, naturalmente, um comportamento espectral homogêneo em todo sua extensão espacial, citando como exemplo mais típico as áreas urbanas.

Segundo Vettorazzi (1992), uma forma de avaliar a homogeneidade das amostras de treinamento é por meio do exame do seu histograma, sendo que uma amostra homogênea terá geralmente um histograma unimodal. Se a amostra incluir componentes de mais de uma classe seu histograma será multimodal.

Outro fator de grande importância na seleção das amostras é o número de pixels amostrados para representar a classe. $\mathrm{Na}$ aplicação de técnicas estatísticas de classificação, o número de pixels das amostras de treinamento devem ser suficientemente 
grandes para permitir as estimativas das classes espectrais a serem mapeadas (Vettorazzi, 1992).

Muitas vezes torna-se dificil a determinação do número de pixels exigido para uma boa amostragem, sendo relativamente fácil quando se trata de áreas com grandes extensões de monocultivo, formando grandes áreas homogêneas na imagem. Entretanto, em áreas com grande variabilidade espacial e espectral, como as diferentes formações naturais e pequenas parcelas agrícolas, essa amostragem torna-se bastante complexa (Büttner et al., 1989 citado por Shimabukuro, 1996).

Swain (1978) relata que, na prática, um mínimo de 10n a 100n pixels, onde n é igual ao número de bandas espectrais, é adequado para uma boa amostragem. Para Mather (1987) o número de pixels em uma amostra de treinamento deve ser no mínimo 30 vezes o número de bandas. Uma vez definida uma boa amostragem, deve-se escolher um método de classificação.

Os métodos de classificação supervisionada mais comumente usados na análise de imagens de sensoriamento remoto são: paralelepípedo, distância mínima (euclidiana e de Mahalanobis) e principalmente a máxima verossimilhança (MaxVer), sendo que esse último é o mais utilizado (Mather, 1987; Crósta, 1992; Lillesand \& Kiefer, 1994). Uma revisão mais detalhada do funcionamento de cada um desses métodos podem ser encontrados em Shimabukuro (1996).

\subsubsection{Classificação textural}

As dificuldades em se classificar as imagens espectrais obtidas por satélites têm aumentado proporcionalmente ao desenvolvimento de sensores de alta resolução como TM do Landsat, HRV do SPOT e SAR do ERS-1 (Marceau et al., 1990). Os algorítmos de classificação "pixel-a-pixel", como por exemplo o MaxVer (máxima verossimilhança) que exige baixa variância espectral, foram originalmente desenvolvidos para serem usados na análise dos dados do sensor MSS do Landsat que possui resolução espacial de $80 \mathrm{~m}$. 
Autores como Rosenfield (1981), Williams et al. (1984), Toll (1984), Irons et al. (1985), Latty et al. (1985) e Goodenough et al. (1996) (citado por Chen, 1996), relatam o aumento da heterogeneidade espectral nos sensores de maior resolução espacial, sendo que esse aumento da variância espectral dos alvos, dificulta a distinção das classes através do uso de classificadores convencionais.

Para diminuir a variância espectral dessas imagens, alguns autores chegaram a propor o uso de filtros tipo passa-baixa. Entretanto, contrariando o avanço tecnológico, essas medidas causam perda de informação espectral em troca de um melhor desempenho de classificação (Chen, 1996).

Objetivando a utilização do total detalhamento dos alvos fornecido pelas imagens geradas em sensores de alta resolução espacial, foram desenvolvidos classificadores por região (per field classifier), que utilizam as informações de um grupo de pixels contíguos num dado campo (Landgrebe, 1980; Latty et al., 1985; Pedley \& Curran, 1991), sendo que esses classificadores analisam não só informações espectrais, mas também texturais e contextuais.

A textura florestal é um dos principais fatores usados pelos fotointérpretes na separação de diferentes formações ou até mesmo na identificação e delimitação de diferentes unidades ambientais e/ou sucessionais dentro de uma área contínua de formação vegetacional (Strahler et al., 1979). Essas diferenças são causadas por variações estruturais dentro da própria floresta como: altura do dossel, diâmetro e densidade das copas, deciduidade, floração, entre outros fatores. Assim como nas fotografias aéreas, as imagens de satélite também apresentam variações texturais de acordo com a estrutura florestal (Harris, 1980).

Para entender melhor os processos de classificação textural, torna-se necessário a conhecimento de alguns conceitos básicos sobre tonalidade e textura, que segundo Haralick (1979), são dois elementos existentes e dependentes com diferentes graus de dominância, sendo que "uma baixa variação dos níveis de cinza de um pequeno bloco de imagem indica que a propriedade dominante é a tonalidade, enquanto uma alta variação indica que a propriedade dominante é a textura". 
Diferentes objetos refletem, emitem e transmitem diferentes quantidades e comprimentos de onda de radiação eletromagnética (Vettorazzi ,1992). Essas diferenças são registradas pelos sensores como diferentes cores ou tonalidades de cinza.

A cor e a tonalidade dos alvos estão sujeitas a variações em função das condições ambientais e de aquisição dos dados (Novo, 1989).

O sistema visual humano só consegue discriminar cerca de 30 tons de cinza e, assim mesmo, só quando eles se encontram bem distribuídos entre o preto e o branco numa escala de $0-255$, respectivamente. As imagens com baixo contraste podem ser expandidas para ocupar todo intervalo disponível e permitir a extração de informações por um analista humano, segundo Crósta (1992). Esse processo é chamado de aumento de contraste ("contrast stretch").

A textura refere-se à variação tonal dentro de uma determinada área, sendo que esta pode ser representada pela repetição aleatória ou determinística de padrões locais. Embora a textura de uma imagem seja facilmente reconhecida visualmente, torna-se tarefa relativamente complexa do ponto de vista computacional, tendo que ser extraída e quantificada a partir dos dados digitais da imagem em sua apresentação estrutural (Chen, 1996).

Vale a pena ressaltar que a determinação da textura em uma imagem está diretamente relacionada a dois fatores: 1) a escala da variação tonal; e 2) a escala da observação, ou seja, a textura observada em uma banda pancromática de um sensor de alta resolução como o HRV-SPOT não pode ser detectada na imagem de um sensor como o AVHRR-NOAA, devido às diferenças de resoluções espaciais que são de $10 \mathrm{~m}$ e 1,1 Km, respectivamente (Mather, 1987).

A menor área da imagem digital que compõe uma textura distinta, é denominada de elemento de textura ou "texel" (Rubin, 1989 citado por Chen, 1996). Existem três componentes de textura: o contraste local, a escala e a orientação. O contraste é a diferença de tom de cinza entre as áreas vizinhas escuras e claras, cujos "pixels" têm níveis de cinza (números digitais) idênticos ou quase idênticos. $O$ contraste local não deve ser confundido com tom, que é a tonalidade média de uma região. A área com alto 
contraste local possui textura rugosa, enquanto a área com baixo contraste local possui textura lisa. As dimensões das áreas escuras e claras definem a escala. Se os niveis de cinza dos "pixels" adjacentes mudam freqüentemente, o contraste característico desta área ocorre em "pixels" muito juntos, resultando em uma textura fina. Quando os tamanhos das áreas escuras ou claras são de vários "pixels", uma aparência de bloco é criada. Conseqüentemente, o contraste caracteristico desta área é observado somente em "pixels" muito distantes, resultando em uma textura grossa. Os termos textura rugosa e textura lisa são usados para descrever o contraste local, enquanto textura grossa e textura fina são usados para descrever o tamanho das áreas escuras e claras num "texel". A orientação diz respeito à preferência da direção das áreas escuras e claras. Quando estas não tem uma orientação preferencial, diz-se que a textura é isotrópica. Por outro lado, se as áreas são consistentemente maiores em uma direção, a textura é anisotrópica (Chen, 1996).

\subsubsection{Métodos de análise textural}

A partir da década de 70, foram desenvolvidos vários métodos de processamento de imagens capazes de analisar as texturas, sendo que a maioria destes baseia-se na distribuição espacial dos níveis de cinza de um segmento de imagem (Chen, 1996). Autores como Haralick (1979); Wechsler (1980) e Van Gool et al. (1985), fizeram

revisões detalhadas dos métodos de processamento de imagens para análise textural, citando vantagens, desvantagens e exemplos de aplicação.

Mais recentemente são descritas novas abordagens para caracterizar as informações texturais como: o método de semivariograma descrito em Curran (1988), Woodcock et al. (1988), Jupp et al. (1989) e Miranda et al. (1992); a unidade textural proposta por Wang e He (1990); o filtro Gabor utilizado por Khazenie \& Richardson (1992); e os modelos de campos aleatórios markovianos relatados por Chellappa \& Jain (1993 citado por, Chen, 1996). 
Um dos estudos pioneiros do uso de classificadores texturais para análise de florestas foi realizado por Strahler et al. (1979). Neste estudo, que objetivou classificar o volume de madeira de uma dada formação florestal, foi utilizada a banda 5 do MSSLandsat para a análise textural, usando para isso uma janela $3 \times 3$ "pixels". Posteriormente, esses dados foram utilizados por Strahler (1981) como um fator de estratificação no estudo de inventário florestal realizado na Califórnia. Woodcock \& Strahler (1987) sugeriram que, devido às altas variações espectrais encontradas nas imagens de florestas e áreas urbanas, produzidas pelos sensores SPOT e Landsat TM, devem ser usadas informações texturais e contextuais para análise dos dados dessas fisionomias.

No Brasil os estudos pioneıros sobre a utilização de classificadores texturais foram realizados por Ó Filho et al. (1980) em imagens obtidas pelo sensor MSS-Landsat, sendo que o método utilizado foi de dependência espacial para a classificação de unidades geológicas.

Em estudos comparativos, Chen (1996) conclui que a Matriz de Co-ocorrência de Níveis de Cinza (GLCM - Grey Level Co-occurrence Matrices), desenvolvida por Haralick et al. (citado por esse mesmo autor), foi o método mais eficiente para analisar a informação textural, além de ter aplicação bastante ampla, sendo usada também pela medicina, uso da terra, segmentação de imagens de satélites e até na classificação de tipos de nuvens. Essa mesma autora afirma que "a ampla variedade de produtos sobre os quais a GLCM foi aplicada para resolver vários problemas, contribuiu para transformá-la na abordagem mais usada atualmente para analisar informação textural de imagens".

O GLCM apresenta vários descritores texturais que utilizam uma série de propriedades que podem ser medidas e comparadas, sendo que o resultado final da utilização de cada descritor textural na imagem original é a criação de novas imagens ou bandas, que serão utilizadas posteriormente para classificação textural. Entre os descritores texturais mais freqüentes utilizados pelo método GLCM estão: Entropia, que mede o grau randômico; Uniformidade, que é o complemento da entropia; Homogeneidade, que quantifica a uniformidade; Contraste; Dissimilaridade, que mede 
quanto os elementos são diferentes entre si; Probabilidade Máxima; Momentos e Momentos Inversos (Inércia, Skewness e Kurtosis); Média e Desvio-Padrão.

Os métodos que incorporam aspectos de textura, tonalidade e contexto na classificação de pixels já são uma realidade irreversível, sendo uma tendência comum nos esforços para geração de novos procedimentos de identificação de padrões, inclusive formulando estratégias híbridas, incorporando e articulando diferentes técnicas, de modo que uma supra as deficiências da outra (Shimabukuro, 1996). 


\subsection{Georreferenciamento das imagens produzidas}

As imagens orbitais e as fotografias aéreas contêm freqüentemente distorções associadas às características como: rotação da terra durante a aquisição de imagens, campo de visada de alguns sensores, curvatura da Terra, variações na plataforma e no sistema óptico do sensor, sendo geralmente necessária a aplicação dos procedimentos de correção geométrica (Crósta, 1992; Vettorazzi, 1992; Shimabukuro, 1996).

No Brasil, o sistema de coordenadas UTM (Universal Transversa de Mercator) é utilizado como padrão para mapas, sendo que nele as distâncias são corretamente representadas (Crósta, 1992).

A função dos programas de correção geométrica é reorganızar os pixels da imagem em relação a um determinado sistema de projeção cartográfica (Novo, 1989).

$O$ processo de registro da imagem estabelece uma relação entre os dados linhacoluna da imagem e um sistema de coordenadas dos dados de uma outra imagem ou de um sistema de projeção particular de um mapa. Essa associação pode ser feita de duas formas: via parâmetros orbitais do satélite (modelo de geometria orbital) ou pela localização dos pontos de controle terrestre ("ground control points - GCPs") na imagem e no sistema de coordenadas de referência (Janssen \& van der Well, 1994).

Os dois sistemas de correção geométrica são usados de forma complementar, no registro da imagem. No Brasil, o INPE executa normalmente a transformação baseada no modelo de geometria orbital em todos os seus produtos, não havendo portanto, a necessidade de se faze-lo posteriormente (Crósta, 1992).

A obtenção de um registro da imagem bem feito está vinculada à uma identificação precisa dos pontos de controle, devendo ser no mínimo de 6 a 10 pontos de controle em uma imagem de 1.000 X 1.000 pixels. Selecionar esses pontos a partir de mapas pode agregar incertezas inerentes ao fato de uma representação cartográfica ser uma idealização e generalização da realidade. O GPS ("Global Positioning System") é uma alternativa para superar essa dificuldade, limitada apenas pela determinação dos 
pontos de controle na imagem orbital onde a identificação é fortemente circunstanciada pela resolução do sensor adotado (Janssen \& van der Well, 1994).

Normalmente, o programa a ser usado para a reformatação da imagem deve oferecer a opção antes de ser aplicada a transformação, comparar os erros obtidos nos ajustes entre os GCPs e os seus equivalentes na imagem. Caso algum dos pontos apresente individualmente um erro considerado alto, deve-se descartá-lo. A margem de erro recomendável é por volta de 1 pixel (Crósta, 1992).

A reformatação da cena em uma base cartográfica é realizada por meı da reamostragem dos pixels com a aplicação de um algorítmo na imagem para gerar uma nova grade correspondente aos eixos euclidianos do sistema escolhido. $\mathrm{O}$ método mais utilizado é o de alocação de vizinho mais próximo por não causar alteração nos valores originais de cinza, mas também existem outros como a interpolação bilinear e convolução cúbica (Novo, 1989; Vettorazzi, 1992). 


\section{METODOLOGIA}

\subsection{Area de estudo}

\subsubsection{Localização}

A Reserva Municipal de Santa Genebra situa-se no distrito de Barão Geraldo, região norte do município de Campinas, SP. Pertencente à Fundação José Pedro de Oliveira e é protegida pela legislação municipal e estadual. Localiza-se às margens da rodovia Campinas-Paulínia, na altura do quilometro 5, entre as coordenadas $22^{\circ} 48^{\prime} 36 \mathrm{~S}$ e $47^{\circ} 07^{\prime \prime} 33 \mathrm{~W}$, e $22^{\circ} 50^{\prime \prime} 10 \mathrm{~S}$ e $47^{\circ} 06^{\prime} 14 \mathrm{~W}$. A Figura 1 mostra a posição da Reserva em relação ao município de Campinas.

A Reserva tem uma área de 251,77 hectares e altitudes que variam entre $580 \mathrm{~m}$ a $670 \mathrm{~m}$, com relevo levemente ondulado (Galetti \& Pedroni, 1994; Zickel, 1995; Morellato \& Leitão Filho, 1995). O fragmento encontra-se em área urbana, cercado de loteamento e áreas com culturas de cana, soja, milho e hortaliças (Castellani \& Stubblebine, 1993).

Devido principalmente a proximidade com a Universidade de Campinas e sua importância como representante de uma pequena parte do que restou das florestas estacionais semideciduais da região, este fragmento tornou-se um dos mais estudados do Brasil, envolvendo mais de 100 trabalhos científicos relacionados com levantamentos florísticos, fitossociológicos, faunísticos, fenológicos, de dieta e comportamento de animais, de sucessão, de biologia reprodutiva, de polinização e outros (Pedroni, 1994; Leitão Filho, 1995). Esses trabalhos, principalmente os levantamentos florísticos e 
fitossociológicos, estão sendo de grande importância para a caracterização das unidades ecológicas do fragmento estudado.

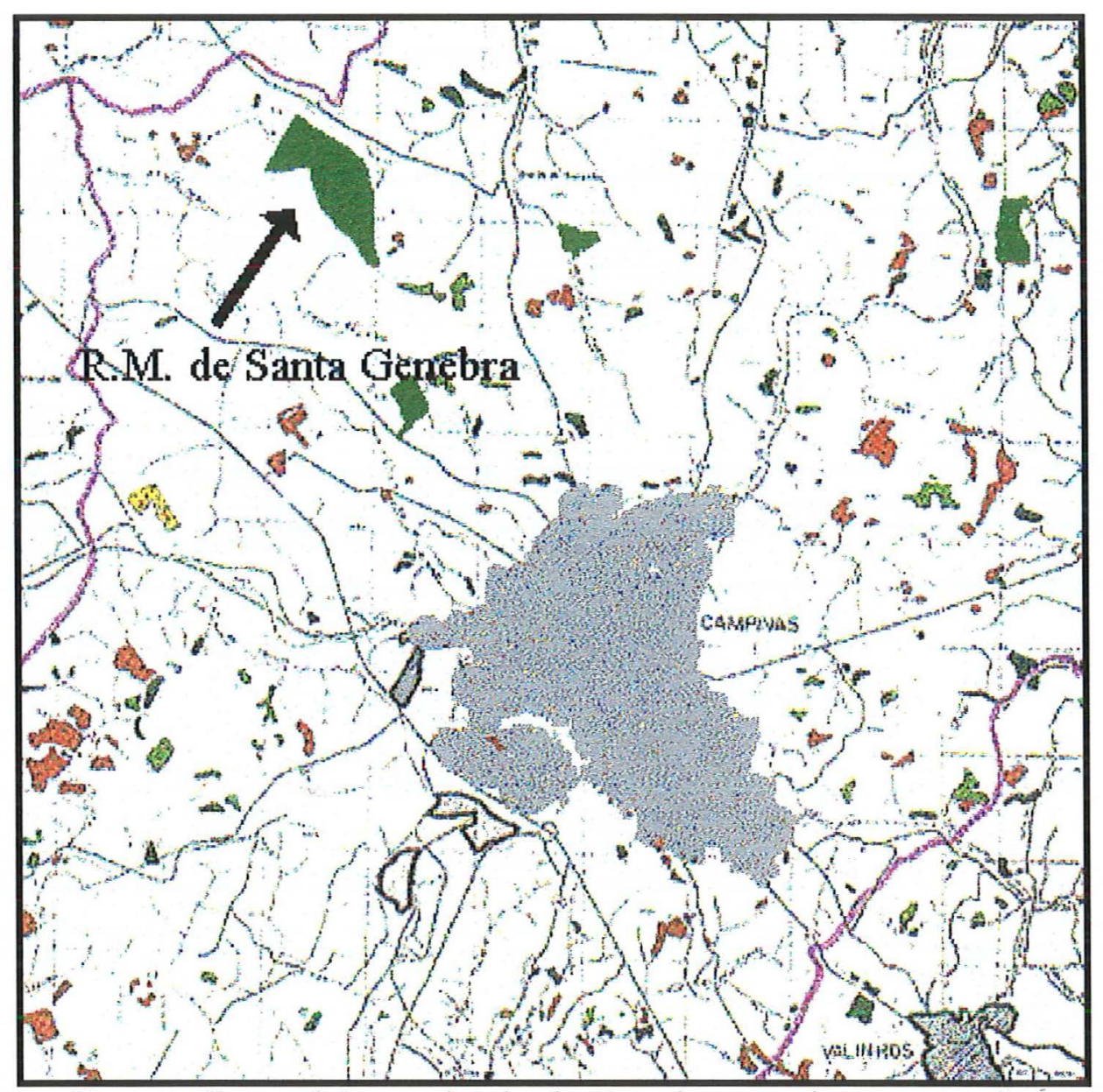

Figura 1 - Situação florestal do município de Campinas; verde escuro = floresta nativa, com indicação da Reserva Municipal de Santa Genebra, adaptado de Kronka (1993).

Segundo Matthes (1991), a floresta de Santa Genebra apresentava em 1962, uma área de aproximadamente $4.018 .680 \mathrm{~m}^{2}(401,86 \mathrm{ha})$; em 1969 essa área foi reduzida para cerca de $2.558 .890 \mathrm{~m}^{2}$ (255,88 ha) e, em 1972 para 2.523.298 m² (252,32 ha). Em 1981, a mata foi doada pela proprietária, Dona Jandyra Pamplona de Oliveira, para o município de Campinas, compreendendo uma área de $2.517 .759 \mathrm{~m}^{2}$ (251,77 ha), segundo a escritura de doação. Nesse mesmo ano foi criada uma Fundação para administração e preservação da Reserva Municipal de Santa Genebra, possibilitando a realização de estudos pesquisas, atividades culturais e de educação ambiental. 


\subsubsection{Vegetação}

O relevo levemente ondulado apresenta áreas mais elevadas, que somam $85 \%$ da área total da Reserva, e regiões de baixada ao longo dos córregos, com $15 \%$ da área total (Leitão Filho, 1995), onde a flora apresenta-se com características muito distintas.

A área mais elevada, que corresponde a maior parte, foi classificada por Andrade Lima (1966) como floresta latifoliada subcaducifólia tropical pluvial ou mata mesófila. Segundo Leitão Filho (1995), o termo mesófila é pouco apropriado para este tipo de formação florestal, devido a sua referência a plantas que crescem em ambientes onde existem condições estáveis de temperatura e umidade, fato que nem sempre ocorre em regiões tropicais. Este mesmo autor considera floresta semidecídua, um termo mais apropriado, devido a parte das espécies arbóreas perderem parcialmente ou totalmente as folhas. Atualmente o termo mais aceito pelos pesquisadores para esse tipo de formação florestal é Floresta Estacional Semidecidual, onde o termo estacional se refere a dupla estacionalidade climática, uma tropical com época de intensas chuvas de verão seguida por estiagem acentuada e outra subtropical sem período seco, mas com seca fisiológica provocada pela queda de temperatura no inverno (IBGE, 1992).

A fisionomia dessas áreas mais elevadas encontra-se bastante alterada devido a vários fatores antrópicos, como a retirada seletiva de madeiras nobres no passado, o possível corte raso de alguns trechos para o aproveitamento de lenha ou a implantação de pequenas "roças de toco", o próprio efeito de fragmentação e isolamento do remanescente e principalmente os impactos causados pelas áreas agrícolas do entorno e a proximidade de pólos industriais, com carreamento de poluentes pelo vento, chuva ácida, descarga de águas superficiais e outros.

Nas baixadas, a floresta estacional semidecidual é substituída pelas florestas sobre solo permanentemente encharcado, também chamados de floresta paludosa ou de brejo na literatura. A Floresta paludosa, apesar de freqüentemente aparecer associada às matas ripárias e de galeria, é uma formação florestal que se diferencia destas por estarem sujeitas à presença d'água em caráter quase permanente no solo (Leitão Filho, 1982; 
Ivanauskas et al., 1997). A condição de umidade no solo contribui para a seletividade das espécies ocorrentes nestas formações, relacionada à adaptabilidade fisiológica das mesmas, de maneira a resistir à saturação hídrica. Nesse caso, devido às condições limitantes desse ambiente, a diversidade de espécies é mais baixa que na floresta estacional semidecidual. Apesar de apresentar um número relativamente baixo de espécies, essa formação apresentou uma elevada densidade de indivíduos, ocorrendo aproximadamente 2700 indivíduos com 10 ou mais centímetros de PAP (perímetro a altura do peito) por hectare e altura média entre 10 - 12 m (Leitão Filho, 1995).

Os fatores que definem a ocorrência de floresta paludosa em solos tipicamente hidromórficos são condicionados a drenagem local da água que corre superficialmente. Essas florestas só ocorrem onde a água tem uma movimentação bem definida em canais superficiais, com tempo de permanência no solo menor que as áreas de campo úmido.

Existe ainda um trecho na Reserva de Santa Genebra onde ocorreu um incêndio de grande impacto no mês de setembro de 1981, atingindo uma área de aproximadamente 5\% (2 ha) do total da floresta (Matthes, 1991; Leitão Filho, 1995). Essa área, que se restringe a parte oeste da reserva, teve seu quadro agravado devido à época do ano que ocorreu o incêndio, já que estava acumulada no solo uma grande quantidade de serapilheira, com baixa umidade no ambiente, promovendo uma grande destruição da vegetação. Nesta ocasião, muitas árvores foram inteiramente queimadas e o estrato herbáceo-arbustivo desapareceu por completo (Matthes, 1991; Castellani \& Stubblebine, 1993; Leitão Filho, 1995).

Na região onde ocorreu o incêndio, apesar de já terem se passado 18 anos, resta atualmente apenas uma capoeira baixa, caracterizada por grandes vazios de vegetação arbustivo-arbórea composta principalmente por arbustos e lianas, sendo que sua regeneração natural encontra-se em processo muito lento. Isso é devido principalmente ao fato desse trecho estar localizado em um dos extremos da reserva com grande área sujeita ao efeito de borda.

Existe atualmente a necessidade de elaboração e implantação de plano de manejo na Reserva, visando à recuperação e à conservação da área. Isso se justifica pelo fato da 
Reserva ser uma unidade de conservação alvo de pesquisa, atividades de educação ambiental (laboratório para estudo e extensão na área ambiental) etc. Essas áreas com alto grau de perturbação apresentam-se fisionomicamente distintas, representando as áreas de borda, áreas com excesso de lianas em desequilíbrio, área queimada e clareiras naturais e antrópicas que estão levando muito tempo para cicatrizarem.

\subsubsection{Clima}

O clima é do tipo Cwa, conforme a classificação de Koeppen, definido por Setzer (1966) como quente úmido, com inverno seco e verão quente chuvoso, sendo que a temperatura do mês mais quente encontra-se acima de $22 \mathrm{C}^{\circ} \mathrm{e}$ a do mês mais frio, abaixo de $18 \mathrm{C}^{\circ}$ e temperatura média anual de $20,6^{\circ} \mathrm{C}$.

Em anos típicos a floresta apresenta dois períodos distintos. Um período ocorre entre os meses de outubro à março, que corresponde a época de maior precipitação e temperaturas elevadas, na qual a floresta apresenta-se em pleno vigor e com folhagem densa (Morellato, 1991; Leitão Filho, 1995). O outro período ocorre entre os meses de abril à agosto, correspondente à época mais fria e seca do ano, sendo nesse período que a floresta apresenta a sua semideciduidade (Leitão Filho, 1995).

O diagrama climático da região de Campinas é apresentado na Figura 2, referente ao período de 1956 a 1987. Acima do gráfico, são apresentadas a altitude, temperatura média anual $\left({ }^{\circ} \mathrm{C}\right)$ e precipitação $(\mathrm{mm})$.

As temperaturas localizadas à esquerda do gráfico e lidas a partir do topo, são: máxima absoluta, média das máximas do mês mais quentes, variação média diária de temperatura, média das mínimas para o mês mais frio e mínima absoluta. A zona preta representa os períodos super úmidos, com precipitação superior a $100 \mathrm{~mm}$ por mês, a zona tracejada representa os períodos úmidos e a pontilhada, quase sem pronunciamento na imagem, representa o período seco. 


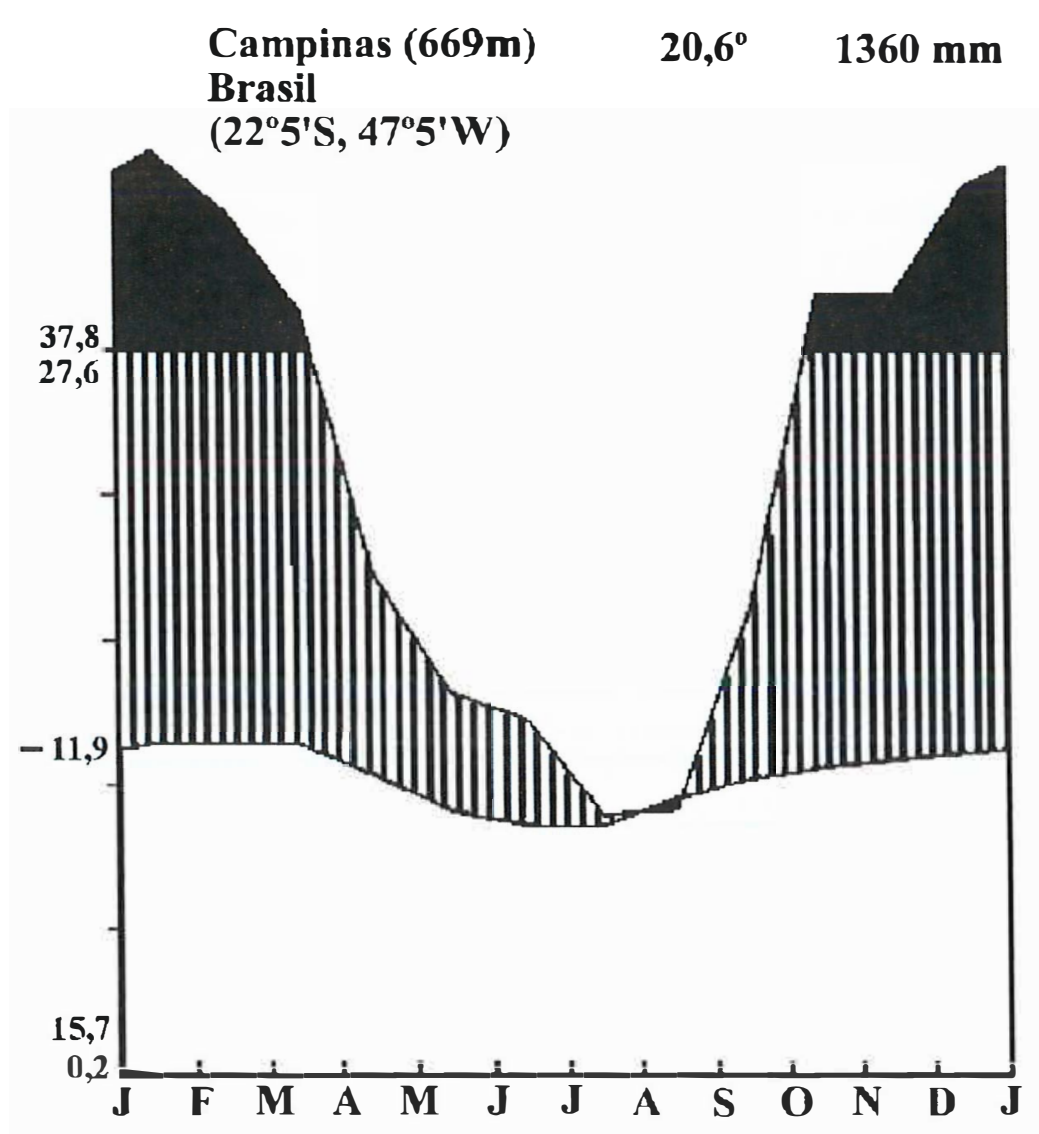

Figura 2 - Diagrama climático para a região de Campinas, no período de 1956 a 1987. (Walter \& Lieth, 1960-67).

\subsection{Identificação e zoneamento das unidades ecológicas por meio de fotografias aéreas e imagens orbitais.}

A identificação e o zoneamento das unidades ecológicas que compõem o mosaico florestal foi realizada através da análise das imagens de satélite e fotografias aéreas pancromáticas. A aplicação de vários testes metodológicos, descritos a seguir, teve como propósito discutir os resultados dessas análises que servirão como base para se recomendar o método de maior eficiência na classificação da vegetação.

A edição das imagens foi realizada no software Adobe Photoshop 3.0, em PC Pentium 100 Mhz, com 32 MB de memória RAM do Departamento de Ciências Biológicas da ESALQ-USP. 


\subsubsection{Análise de imagens aerofotográficas}

Para a análise do mosaico florestal e zoneamento das unidades ecológicas usando as fotografias aéreas pancromáticas, foram adquiridos os pares estereoscópios das fotografias de julho de 1972, junho de 1978, junho de 1994 e dezembro de 1994, nas escalas de 1:25.000, 1:35.000, 1:25.000 e 1:5.000, respectivamente.

As fotografias em escala 1:5.000, de dezembro de 1994, não registraram toda a área da Reserva florestal, faltando uma das extremidades ao norte. Essa área não foi fotografada em função de não corresponder aos objetivos do projeto aerofotogramétrico, que foi de planejamento urbano do município de Campinas. Entretanto, por serem consideradas de relevante valor para esse trabalho, essas fotografias foram analisadas mesmo abrangendo aproximadamente $80 \%$ da área total da Reserva. No total, foram usadas 11 fotografias para a formação dos pares estereoscópicos, devido a escala de trabalho.

O zoneamento fitoecológico através da fotointerpretação foi realizado utilizandose basicamente três métodos: análise analógica com estereoscopia; análise analógica de fotografia aérea em formato digital usando o programa Adobe Photoshop 3.0 e classificação textural usando o ER Mapper 5.2, conforme descrições a seguir.

\subsubsection{Análise analógica com estereoscopia}

Neste método, considerado o mais usado nesse tipo de análise, as fotografias de julho de 1972, junho de 1978, junho de 1994 e dezembro de 1994, nas respectivas escalas 1:25.000, 1:35.000, 1:25.000 e 1:5.000, foram analisadas analogicamente, usando para isso um estereoscópio de espelhos para obtenção de efeito tridimensional das imagens. Desse modo, foi realizado um pré-zoneamento desenhando-se no Terkron (acetato transparente) colocado sobre as fotografias. Foram usados lápis com cores distintas para representar em forma de desenho, as unidades vegetacionais diferenciadas. Esses desenhos foram posteriormente escanerizados e editados no Adobe Photoshop 3.0. 
A fotointerpretação teve em primeira análise, um pré-zoneamento baseado nos níveis distintos de altura da floresta. A princípio, para esse tipo de análise foram mapeadas três classes de alturas classificadas como sendo: 1) nível herbáceo-arbustivo (nas clareiras, efeito de borda ou onde houve grande grau de perturbação antrópica); 2) nível arbóreo, onde as árvores encontram-se no dossel da floresta apresentando copa ampla e aparência vigorosa; e 3) nível intermediário, onde mapeou-se áreas classificadas como "áreas com árvores em desenvolvimento apresentando copa estreita e altura superior ao do estrato herbáceo-arbustivo e inferior ao dossel". Posteriormente, foi realizada uma separação visual das unidades ecológicas na Reserva, de acordo com a tonalidade, textura e localização.

Desse modo, as áreas interpretadas como herbáceo-arbustivo e localizadas no entorno do fragmento, foram consideradas como uma única unidade ecológica, "faixa com efeito de borda", assim como essa mesma vegetação herbáceo-arbustivo foi considerada "área queimada", no local onde historicamente já se conhecia este tipo de perturbação antrópica. A diferenciação de texturas também permitiu separar a unidade de Floresta paludosa das outras unidades ecológicas.

\subsubsection{Análise analógica de fotografia aérea em formato digital}

Algumas das dificuldades encontradas no uso da estereoscopia foram a pequena ampliação da imagem e o baixo contraste, que dificultaram e tornaram mais subjetivas as escolhas das classes. Nesse tipo de análise foi realizada a transformação da imagem fotográfica (fotografia de junho de 1994 em escala 1:25.000) em imagem digital. Essa transformação foi realizada através da escanerização com alta resolução espacial (1.000 dpi), na tentativa de se conservar ao máximo as características de resolução espacial da fotografia original.

Essa imagem digital foi classificada visualmente através da exibição da imagem no monitor do microcomputador, de modo interativo entre o operador e o software (Adobe Photoshop 3.0), onde foram utilizados recursos como ampliação (zoom) e realce 
da imagem através de mudanças no brilho e contraste. Esse zoneamento foi realizado através da delimitação das áreas, usando para isso a ferramenta de "laço" e pintando com cores distintas, as diferentes unidades ecológicas identificadas na análise.

\subsubsection{Classificação textural da fotografia aérea}

Para o processamento das imagens foi escolhido o software ER Mapper (Earth Resource Mapping's), por possuir boas características operacionais e uma ótima performance (Graham, 1996). Esse software foi considerado apropriado para fazer as análises necessárias para este trabalho, por apresentar características importantes para sua realização como a presença do algoritmo GLCM no módulo de Radar, para extração das informações texturais, e ainda possibilitando a classificação de mais de três bandas ao mesmo tempo, além de outros recursos. Os testes no ER Mapper, apesar de poderem ser realizados em PCs, foram feitos em estações de trabalho do Laboratório de Processamento de Informações Georreferenciadas (LAPIG) do Departamento de Geociências da UNICAMP.

Para a utilização do GLCM, foi escolhida previamente uma fotografia aérea na escala 1:5.000 de dezembro de 1994, contendo a parte central da Reserva, que apresentava quase todas as texturas reconhecidas visualmente para a área total da Reserva Municipal de Santa Genebra. A utilização prévia de apenas uma fotografia contendo parte da Reserva foi necessária pelo fato de que a resolução na qual foi escanerizada (300 dpi) gerou um arquivo com aproximadamente $25 \mathrm{MB}$. Essa grande dimensão do arquivo da imagem fez com que cada teste demorasse várias horas para ser realizado, forçando a delimitação posterior de uma sub-amostragem com $25 \%$ da imagem digital original. A fotografia aérea utilizada nesta análise é apresentada na Figura 3.

O GLCM necessita do fornecimento de vários parâmetros de entrada, que são: 1) tamanho da janela móvel; 2) número de níveis de cinza (1 a 8 bits); 3) orientação da coocorrência; 4) distância de deslocamento; e 5) descritor de textura. Esses parâmetros, quando combinados entre si, podem gerar inúmeras imagens, devendo no entanto, essa 
análise e decisões, estarem precedidas de um conhecimento básico usando bibliografia adequada ou pré-testes, que possibilitem a melhor escolha dos parâmetros para serem usados.

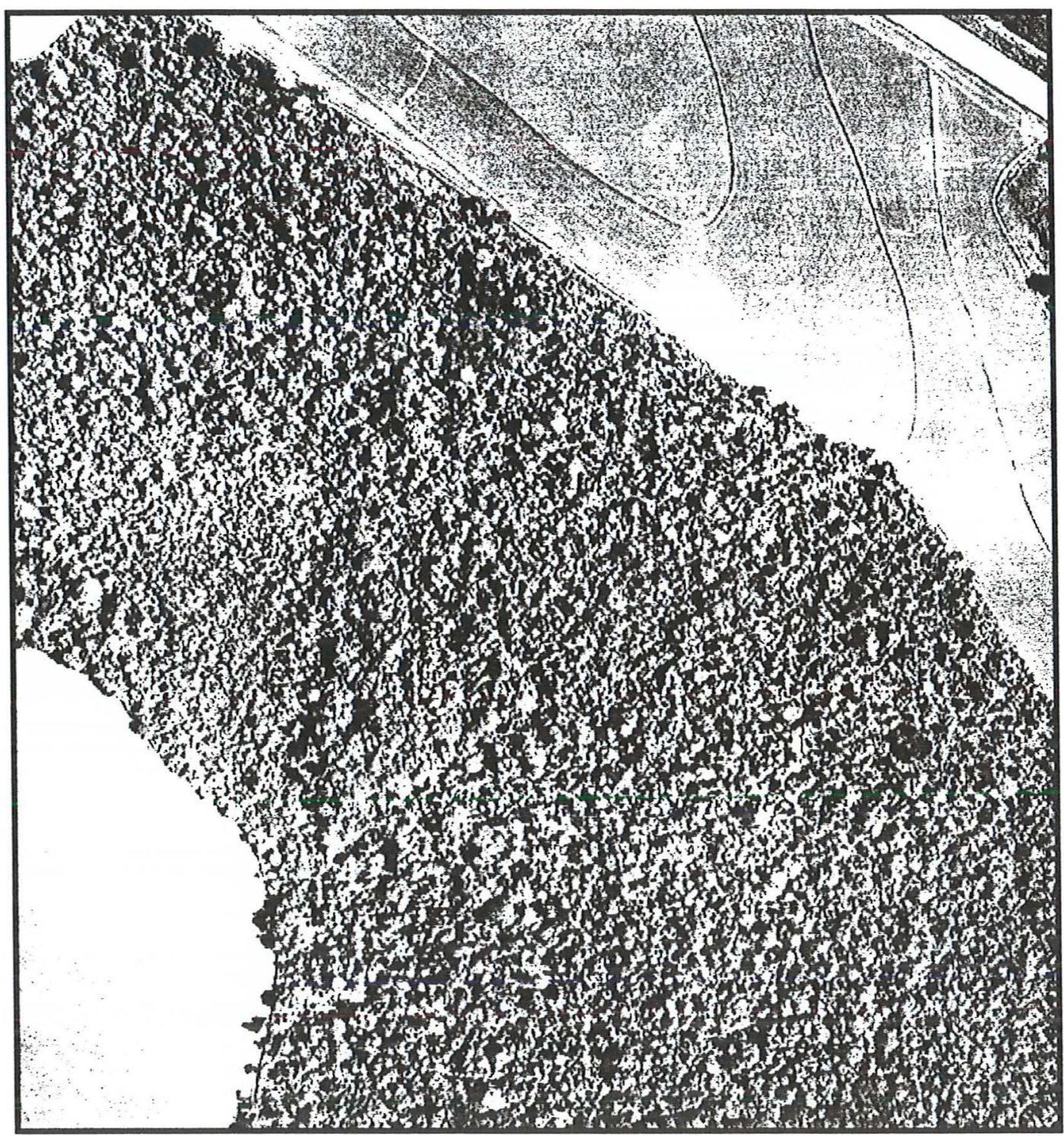

Figura 3 - Fotografia aérea da porção central da Reserva Municipal de Santa Genebra, Campinas, SP, (1:5.000, dezembro de 1994), utilizada na classificação textural.

Os descritores texturais encontrados no método GLCM do ER Mapper são: Contraste; Dissimilaridade; Entropia; Homogeneidade; Momentos Inversos (1 ${ }^{\mathrm{a}} ; 2^{\mathrm{a}}$ e $3^{\mathrm{a}}$ 
ordem); Probabilidade Máxima; Média; Momentos (1 $1^{\mathrm{a}} ; 2^{\mathrm{a}}$ e $3^{\mathrm{a}}$ ordem); Desvio-Padrão e; Uniformidade.

Foram realizados vários testes utilizando cada um dos 14 descritores texturais, sendo que o único parâmetro fixado foi o da orientação da co-ocorrência. Levando-se em consideração que a vegetação natural é isotrópica, ou seja, não há uma preferência de orientação, qualquer direção escolhida para analisar as informações texturais deve apresentar resultados semelhantes (Wang, 1994 e Chen, 1996). Portanto, a direção horizontal $\left(0^{\circ}\right)$ foi considerada para todos os descritores utilizados.

Os melhores resultados dos testes realizados em cada um dos descritores utilizados, ou seja, aqueles que apresentaram maior quantidade de informações texturais, foram selecionados e usados como bandas individuais na classificação da imagem.

A classificação das bandas contendo as informações texturais foi realizada através do algorítmo de classificação não supervisionada (Isodata), onde foram usados os melhores resultados das bandas texturais de forma simultânea. Posteriormente, foi gerada uma série de imagens com diferentes números de classes para que pudessem ser analisadas e escolhidas, com base em conhecimento de campo e análise das fotografias aéreas, as imagens com melhor acurácia entre as classes obtidas e a realidade de campo. Os parâmetros fornecidos para o classificador não supervisionado são listados na Tabela 3.

Tabela 3 - Parâmetros fornecidos para o classificador Isodata na análise das bandas texturais da fotografia aérea de dezembro de 1994 na escala 1:5.000, Reserva Municipal de Santa Genebra, Campinas, SP.

\begin{tabular}{|l|c|}
\hline Parâmetros & \\
\hline número mínimo de pixels por classe & $0,01 \%$ \\
\hline limite para o desvio padrão & 4,5 \\
\hline distância mínima entre as médias das classes & 3,2 \\
\hline número total de iterações & 500 \\
\hline número de células estáveis durante a iteração & $98 \%$ \\
\hline intervalo de amostragens de linhas e colunas & 1 \\
\hline número máximo de classes variável & 4 a 10 \\
\hline valor de separação & 0 \\
\hline
\end{tabular}




\subsubsection{Análise de imagens orbitais}

Existem duas formas de análise de imagens orbitais multiespectrais (Vettorazzi, 1992) análise visual/analógica (quando é feita uma interpretação visual de imagens fotográficas) e análise digital (o produto obtido a partir de imageadores orbitais, são apresentados sob a forma de dados gravados em meio apropriado para análise por meio de computadores).

Para esse trabalho, foram analisadas digitalmente as imagens Landsat TM de 1989 e SPOT XS de 1988, obtidas no Núcleo de Monitoramento Ambiental da EMBRAPA (NMA) e no Departamento de Geociências da UNICAMP, respectivamente. As análises foram feitas objetivando testes metodológicos, sendo necessários vários processamentos da imagem, na busca de um melhor resultado para a classificação do mosaico florestal.

Embora as imagens Landsat TM apresentem menor resolução espacial que as imagens geradas pelo SPOT XS, a sua utilização neste trabalho é justificada pela maior disponibilidade dessas imagens no mercado e principalmente pela existência de um maior número de bandas, aumentando a sua resolução espectral.

A utilização de um maior número de bandas em uma classificação digital geralmente faz com que aumente a precisão da classificação. Entretanto, o aumento no número de cálculos necessários à classificação se tornam mais demorados e complexos (Crósta, 1992).

A classificação supervisionada não foi utilizada devido à falta da localização exata das unidades ambientais e sucessionais do remanescente florestal em questão e a intensa fragmentação de algumas unidades ecológicas, impedindo que se pudesse fazer uma amostra de treinamento sem encorrer em erros de amostragem. Além disso, com o tamanho relativamente pequeno do fragmento florestal, a amostragem provavelmente seria insuficiente devido ao baixo número de pixels disponíveis. 
Devido à importância de se fazer uma boa amostragem, já relatada no item 2.3.2. que fala sobre a classificação supervisionada, esse tipo de análise não pode ser utilizado nesse trabalho.

Durante essa etapa de análise das imagens, foram necessárias várias visitas de reconhecimento e checagem de padrões da vegetação na Reserva Municipal de Santa Genebra, com o intuito de correlacionar a vegetação com as imagens orbitais e fotografias aéreas e ainda realizar uma análise prévia dos resultados obtidos.

\subsubsection{Classificação não supervisionada das imagens Landsat TM}

Com base nas afirmações anteriores, foram realizadas classificações não supervisionadas nas bandas 2, 3, 4, 5 e 7 da imagem de satélite Landsat TM, orbita/ponto 219/76 de 14 de agosto de 1989. A banda 1 deixou de ser utilizada por apresentar-se em arquivo danificado e a banda 6 com incompatibilidade de escala espacial, além de se referir ao espectro emitido e não refletido.

A aplicação desse método foi realizada por meı do algorítmo "Isodata" disponivel no software ER Mapper, que identifica as concentrações naturais dos dados no espaço K-dimensional dos atributos, extraindo de cada grupo, ou "cluster", as assinaturas espectrais correspondentes a uma classe desconhecida. Foram usadas todas as bandas simultaneamente para a classificação da imagem, gerando uma série de imagens com diferentes números de classes, para que pudesse ser escolhido, com base em conhecimento de campo e análise das fotografias aéreas, uma imagem que aparentemente tivesse uma melhor relação entre as classes obtidas e a realidade de campo. Os parâmetros fornecidos para o classificador não supervisionado são listados na Tabela 4. 
Tabela 4 - Parâmetros fornecidos para o classificador Isodata na análise das imagens Landsat TM 2, 3, 4, 5 e 7 de 1989, Reserva Municipal de Santa Genebra, Campinas, SP.

\begin{tabular}{|l|c|}
\hline Parâmetros & \\
\hline número mínimo de pixels por classe & $0,01 \%$ \\
\hline limite para o desvio padrão & 4,5 \\
\hline distância mínima entre as médias das classes & 3,2 \\
\hline número total de iterações & 500 \\
\hline número de células estáveis durante a iteração & $98 \%$ \\
\hline intervalo de amostragens de linhas e colunas & 1 \\
\hline número máximo de classes variável & 4 à 24 \\
\hline valor de separação & 0 \\
\hline
\end{tabular}

\subsubsection{Classificação textural e espectral/textural da imagem Landsat TM}

Para a utilização do GLCM usando imagens multiespectrais é necessário que se escolha uma banda para fazer as extrações de texturas, sendo que essa deve conter o maior variação espacial dos níveis de cinza. Segundo o trabalho realizado por Chavez (1992), essa variação espacial nas imagens Landsat TM e SPOT, é maior na banda do infravermelho próximo, do que nas bandas do visível, especialmente nas imagens com cobertura de vegetações densas. Chen (1996) comparou a variação espacial das bandas do infravermelho (4 e 5) do Landsat TM e concluiu que a banda 4 apresentou-se com uma variabilidade espacial ligeiramente maior ou igual a banda 5. Marceau (1990) também considerou a banda 3 do SPOT XS como sendo a mais apropriada para classificação textural. Baseado nestes trabalhos, a banda 4 do Landsat TM foi escolhida para a extração de informações texturais.

A classificação foi feita de duas manerras: uma só textural, usando apenas as bandas resultantes da extração de informações texturais pelos vários descritores; e outra usando além das bandas texturais, as bandas espectrais $2,3,4,5$ e 7 . 
Com exceção da escolha da banda para extração de informações texturais e da inclusão das bandas espectrais na classificação espectral/textural, todos os outros procedimentos para realização dessas classificações se igualam aos já descritos no item 3.2.1.3., inclusive os parâmetros fornecidos para o classificador não supervisionado.

\subsubsection{Classificação não supervisionada das imagens SPOT XS}

A imagem SPOT XS usada nesse trabalho foi obtida através do Departamento de Geociências da UNICAMP, com orbita/ponto no sistema SPOT de K715/J396, passagem de 18 de maio de 1988 .

Seguindo a mesma metodologia descrita para as imagens Landsat TM no item 3.2.2.1., a aplicação do método foi realizada através do algorítmo "Isodata", usando simultaneamente as três bandas multiespectrais do SPOT XS. Os parâmetros fornecidos para o classificador não supervisionado são listados na Tabela 5.

Tabela 5 - Parâmetros fornecidos para o classificador Isodata na análise das imagens SPOT XS, Reserva Municipal de Santa Genebra, Campinas, SP.

\begin{tabular}{|l|c|}
\hline Parâmetros & \\
\hline número mínimo de pixels por classe & $0,01 \%$ \\
\hline limite para o desvio padrão & 4,5 \\
\hline distância mínima entre as médias das classes & 3,2 \\
\hline número total de iterações & 500 \\
\hline número de células estáveis durante a iteração & $98 \%$ \\
\hline intervalo de amostragens de linhas e colunas & 1 \\
\hline número máximo de classes variável & 4 a 10 \\
\hline valor de separação & 0 \\
\hline
\end{tabular}




\subsubsection{Classificação textural e espectral/textural da imagem SPOT}

Baseado nos resultados dos trabalhos apresentados no item 3.2.2.2., a banda 3 do SPOT XS de 18 de maio de 1988, foi escolhida para a extração de informações texturais por apresentar maior variabilidade espacial dos níveis de cinza.

Essa classificação, como nas imagens TM, também foi feita de duas maneiras: uma só textural usando apenas as bandas resultantes da extração de informações texturais

pelos vários descritores e; outra usando além das bandas texturais, as bandas espectrais 1, 2 , e 3 .

Com exceção da escolha da banda para extração de informações texturais, todos os outros procedimentos para realização da classificação textural se igualam aos já descritos no item 3.2.1.3., inclusive os parâmetros fornecidos para o classificador não supervisionado.

\subsection{Georreferenciamento das imagens e localização das unidades ecológicas}

Para o georreferenciamento das imagens partiu-se primeiramente para a obtenção no campo das coordenadas que serviram como pontos de controle necessários para o processamento das imagens. O equipamento GPS foi levado a campo onde coletou-se as coordenadas dos pontos de controle em todo o entorno do fragmento e das áreas onde foram realizados os diversos levantamentos florísticos e fitossociológicos nas referidas unidades ecológicas.

Na obtenção dos pontos de controle necessários para o georreferenciamento das imagens foi utilizado o GPS (Global Positioning System) Corvallis MC-V DR D-3, com base Magmavox para fazer a correção diferencial. O software utilizado para a coleta de dados na base foi o Winbase 1.0 e para a correção foi utilizado o PC GPS Versão 2.4 da Corvallis Microtechnology, Inc. Todos esses equipamentos e softwares utilizados nessa coleta de dados pertencem ao Laboratório de Métodos Quantitativos do Departamento de 
Ciências Florestais da ESALQ/USP que se localiza-se aproximadamente $65 \mathrm{Km}$ de distância em linha reta do fragmento estudado.

Esses dados foram utilizados no IDRISI 2.0 para georreferenciar as imagens através dos comandos Reformat e Resample. O algorítmo de reamostragem aplicado à imagem foi o de "alocação do vizinho mais próximo". Esse processamento foi realizado no Laboratório de Geoprocessamento do Setor de Topografia e Fotointerpretação do Departamento de Engenharia Rural da ESALQ/USP.

As imagens foram georreferenciadas com coordenadas em UTM, apresentando um grid com espaçamento de $500 \mathrm{~m}$ e com algumas correções de erros de interpretação detectadas na etapa de checagem de campo e já comentadas no item anterior (3.2.).

A coleta de coordenadas geográficas das unidades ecológicas foi realizada através da abertura de várias trilhas de acesso que confirmaram ou não a existência das unidades e as suas localizações em mapa, auxiliando o trabalho de caracterização.

As imagens georreferenciadas foram marcadas por pontos pretos que representam as regiões centrais onde foram realizadas as caracterizações florísticas, fisionômicas e estruturais. Estes pontos foram localizados no mapa por orientação das coordenadas obtidas pelo GPS. Os mapas apresentam ainda uma trilha central, representada por uma linha, que atravessa a Reserva passando por várias das unidades ecológicas.

\subsection{Análise da exatidão das imagens classificadas}

A exatidão da classificação de um mapa é freqüentemente representada através do estabelecimento da porcentagem da área do mapa corretamente classificada em comparação aos dados de referência que são definidos como verdade terrestre (Story \& Congalton, 1986). A matriz de erro é geralmente usada para obter esta porcentagem, permitindo que o analista determine o desempenho da classificação para categorias individuais e para classificação total (Congalton et al., 1993), favorecendo a visualização dos resultados e auxiliando na verificação da aleatoriedade dos erros (Shimabukuro, 
1996).

A análise Kappa é um outro procedimento muito usado e recomendado na avaliação da exatidão, geralmente definido como método padrão (Cohen, 1960; Rosenfield \& Fitzpatrick-Lins, 1986). A utilização do coeficiente Kappa possibilita avaliar a concordância dos resultados da classificação com sua informação de referência, que foi obtida pelo mapa, pelos trabalhos de campo, pelas fotografias aéreas, etc. (Chen, 1996). Entretanto, a utilização da matriz de erro e do coeficiente Kappa necessitam dos dados de referência para que as classificações possam ser comparadas. $O$ coeficiente Kappa utiliza todos os elementos da matriz para seu cálculo, ao contrário do desempenho médio que mostra a porcentagem de pixels classificados corretamente (Chen, 1996).

Um detalhamento sobre os métodos de avaliação da exatidão de classificação pode ser encontrado em Shimabukuro (1996).

Devido as dificuldades e até mesmo inviabilidade de se amostrar toda a área estudada, muitos pesquisadores utilizam-se de procedimentos de amostragem para estimar a exatidão da classificação (Benson et al., 1971 e Rosenfield, 1982). Alguns autores como Congalton (1991) e Hay (1979) sugerem a coleta de um mínimo de 50 amostras para cada categoria. Entretanto, o tempo e os custos são fatores significativos no estabelecimento do tamanho da amostra para os procedimentos de avaliação da exatidão (Bailey et al., 1994 citado por Shimabukuro, 1996).

Dentro desse contexto, mesmo pensando no estabelecimento de 50 pontos de amostragem do fragmento estudado, esse procedimento tornou-se inviável na relação custo/benefício, em função de vários fatores. O principal deles foi a extrema dificuldade de deslocamento na maior parte das unidades ecológicas que se encontram atualmente com alto grau de degradação. A travessia em áreas constantemente encontradas como emaranhado de lianas, touceiras de bambu, árvores e galhadas caídas cobertas por lianas, presença de várias espécies urticantes e cortantes, além da densidade elevada de indivíduos do estádio inicial de sucessão, fazem com que o deslocamento nesses locais se torne extremamente vagaroso, exaustivo, sem condições de ser realizado sem a produção de um grande impacto na unidade. (Vide Figuras 10, 11, 12, 13 e 14 no item 4.4.2.). 
Outro fator importante é a extrema complexidade do mosaico florestal (ambiental e sucessional) no próprio campo, com presença de ecótonos entre essas unidades ecológicas a distâncias muito próximas em situações identificadas na área. Esses ecótonos caracterizam-se como zona de transição entre as diferentes unidades ecológicas ou biomas adjacentes podendo ser gradual, abrupta, em mosaico ou ainda apresentar estrutura própria (Watanabe, 1997).

Na Reserva de Santa Genebra, esses ecótonos geralmente apresentavam-se na forma de um gradiente transicional, com caraterísticas fisionômicas e florísticas intermediárias entre as duas unidades ecológicas adjacentes e ainda em faixas que variam de poucos metros até dezenas de metros.

Essa condição ecotonal é ainda mais complexa para o estabelecimento de pontos de checagem quando as unidades ecológicas possuem diferenças apenas sucessionais e não fisionômicas, onde a passagem de um estado ecológico para outro é necessariamente um estado de transição que pode ser classificada em qualquer uma das unidades adjacentes. Nessas condições, até mesmo pessoas com muita experiência de campo, podem se enganar em relação a classificação da unidade ecológica (Gandolfi, 1999).

Essa dificuldade já foi encontrada na fase de fotointerpretação, onde o gradiente físionômico colaborou em grande parte para a subjetividade da delimitação das unidades ecológicas, ao contrário do que acontece na classificação de feições fisionomicamente distintas, que possuem seus limites geralmente muito bem definidos, como as áreas agrícolas.

Nessas condições, até mesmo uma amostragem aleatória da verdade terrestre é extremamente complexa, vagarosa (inviável em tempo hábil) e ainda sujeita a erros de interpretação, dependendo da abertura de várias trilhas com a orientação de GPS.

Outros fatores como a obtenção e precisão das coordenadas dentro da floresta com dossel fechado e denso, dificultam ainda mais para o estabelecimento de pontos de checagem.

Dessa forma, a estratégia usada para a obtenção das matrizes de erro e coeficiente Kappa foi a escolha de um dos mapas produzidos pelas classificações como melhor 
representante da verdade terrestre. Os critérios usadas para escolha desse mapa está descrito no item 4.4 .

Com os dados de referência e os mapas obtidos pelos diferentes métodos foram construídas matrizes de erro com o auxílio do programa IDRISI 2.0. Através das matrizes pode se obter os coeficientes de exatidão global e individual, desempenho médio e também os coeficientes de concordância Kappa global e individual para cada categoria.

\subsection{Checagem prévia das unidades ecológicas no campo e caracterização florística, fisionômica e estrutural dessas unidades identificadas nas classificações das imagens.}

A checagem prévia de campo foi realizada através de caminhadas definidas no interior e no entorno da Reserva, orientados por bússola, GPS e pelos próprios mapas produzidos, visando checar a existência das unidades ecológicas identificadas nas classificações das imagens e adequação de seus limites.

Posteriormente foi realizada outra checagem de campo para aferição da qualidade e confiabilidade do zoneamento das unidades ecológicas apresentadas nos mapas, junto com uma caracterização vegetacional dessas unidades ecológicas. Para isso, foi usado o método de transecto como método de levantamento expedito, que permitiu uma aferição da qualidade e confiabilidade do zoneamento das unidades ecológicas e a verificação da verdade terrestre com os resultados obtidos na interpretação das imagens. A localização em mapa dos locais onde se realizaram os levantamentos floristicos e fitossociológicos foi feita através da utilização do equipamento GPS, já descrito no item 3.3.

Essa caracterização vegetacional das unidades foi realizada através de levantamento florístico, estrutural e fisionômico de cada unidade ecológica identificada no campo. Como já existiam 3 trabalhos florísticos e fitossociológicos realizados em unidades ecológicas da Reserva, os dados fornecidos por estes levantamentos foram aproveitados nessa caracterização de suas respectivas unidades.

Para o levantamento fitossociológico de cada unidade foi usado o método de transecto subdividido em parcelas de $2 \mathrm{~m} \times 10 \mathrm{~m}$ de $\left(20 \mathrm{~m}^{2}\right)$. Os transectos foram 
demarcados com barbante atravessando os trechos mais representativos de cada unidade ecológica ("zona core"). A amostragem das bordas das unidades ecológicas foram evitadas para que não fossem amostradas as áreas de transição (ecótonos) entre unidades distintas.

Em cada parcela foram amostrados todos os indivíduos que apresentaram altura acima de 1 metro. A área amostrada em cada unidade ecológica foi de $1.000 \mathrm{~m}^{2}$ (10 parcelas), para "faixa com efeito de borda" e "área queimada" e $1.500 \mathrm{~m}^{2}$ (15 parcelas), para "floresta de brejo" e "maciço de Diatenopteryx sorbifolia Radlk.", totalizando 5.000 $\mathrm{m}^{2}$ amostrados em todas as unidades.

Para cada individuo amostrado foram anotados os dados de PAP (perímetro a altura do peito - $1,30 \mathrm{~m}$ ), altura dos indivíduos e coletado material botânico para posterior identificação.

Os trabalhos já realizados em algumas das unidades identificadas cujos dados foram aproveitados nessa análise somam cerca de 1,94 ha (Gandolfi, 1999; Martins, 1999; Rodrigues et al., 1998), totalizando 2,44 ha de área amostrada na checagem de campo.

O trabalho de Rodrigues et al. (1998) foi realizado num trecho da unidade "áreas sem indícios de perturbação recente" e o de Gandolfi, (1999) realizado num trecho da unidade "áreas sem indicios de perturbação recente" (representadas pelas áreas de estudo A e C no referido trabalho) e num trecho da unidade "áreas com indícios de perturbação recente" (representada pela área de estudo B no referido trabalho) e o trabalho de Martins, (1999) foi realizados nas áreas de clareiras.

Esses trabalhos fitossociológicos, com exceção de Martins (1999), foram realizados utilizando o método de parcelas contíguas, com parcelas de $10 \mathrm{~m}$ x $10 \mathrm{~m}$. Nesses dois trabalhos, em cada parcela, foram plaqueados todos os indivíduos vivos, com PAP (perímetro na altura do peito $-1,30 \mathrm{~m}$ ) $\geq$ a $15 \mathrm{~cm}$ (ou DAP $\geq 4,8 \mathrm{~cm}$ ). Para todos os individuos amostrados foi estimada a altura, medido o perímetro, coletado material botânico para sua identificação e anotada as coordenadas para o mapeamento. 
No trabalho de Martins (1999), a amostragem foi realizada no interior das clareiras delimitadas de acordo com metodologia específica e os indivíduos com mais de $50 \mathrm{~cm}$ de altura foram amostrados.

Nas unidades ecológicas cuja físionomia atual não era de domínio florestal, como a faixa com efeito de borda e a área queimada, não foram anotados os dados de perímetro e altura, devido à complexidade das ramificações da forma de vida predominante (lianas), porém foram levantados dados de abundância das espécies na área. Para isso foi anotado o número de aparecimentos (indivíduos) de cada espécie amostrada, tomando-se especial cuidado nos emaranhados de lianas para não amostrar o mesmo indivíduo 2 vezes.

A listagem florística de cada unidade vegetacional foi elaborada através das espécies amostradas nas unidades amostrais e complementadas por caminhadas regulares pela unidade ecológica, visando amostrar o maior número possível de espécies daquela unidade.

O material botânico foi processado e identificado no Departamento de Ciências Biológicas da ESALQ/USP e depositado no Herbário ESA dessa mesma unidade.

Todo material necessário para a caracterização da vegetação das unidade ecológicas foi fornecido pelo Departamento de Ciências Biológicas da ESALQ-USP que se constituiu de tesouras de alta poda, tesouras de poda, facões, fita métrica, trena, sacos de coleta, fita crepe, fitas biodegradáveis, binóculos, prensas, máquina fotográfica, canivete, prancheta e planilha de campo. As amostras botânicas de todos os indivíduos amostrados foram coletadas, secas em estufa e a maior parte identificadas no herbário ESA do mesmo departamento, sendo que o material botânico de maior complexidade taxonômica foi enviado para especialistas.

Os dados foram analisados utilizando-se o programa FITOPAC (Shepherd, 1995). Os parâmetros considerados foram os normalmente utilizados em levantamentos fitossociológicos e estão descritos em Whittaker (1972), Mueller Dombois \& Ellemberg (1974) e Rodrigues (1988). 
Vale ressaltar que para todas as unidades ecológicas estudadas, a suficiência amostral foi constatada através da estabilização da curva do coletor.

$\mathrm{Na}$ descrição fisionômica de cada unidade ecológica foram usados os dados de altura e dominância dos estratos, formas de vida ocorrentes e predominantes e espécies mais representativas dessas formas de vida.

\subsection{Análise de similaridade florística entre as unidades amostrais das unidades ecológicas}

A similaridade florística entre as parcelas das unidades ecológicas foi verificada através da técnica de análise de agrupamentos (Cluster Analysis), utilizando os índice de Sorensen de similaridade, para as análises qualitativas e quantitativas, resultando na construção de dendrogramas com base na média de grupo (UPGMA). A utilização do indice de Sorensen, disponível no PC-Ord, tem sido o mais indicado neste tipo de análise, apresentando resultados considerados melhores que o de Jaccard (Gauch, 1981; Hill, 1979b; Prentice, 1980; Sockal \& Rohlf, 1995).

A ordenação dos dados foi realizada através do método da análise de coordenadas principais (PCO) (Siqueira, 1993; Salis et al., 1995; Ivanauskas, 1997), para as análises qualitativas e o método de análises dos componentes principais (PCA) para as análises quantitativas.

As análises de classificação e de ordenação foram realizadas pelos programas PCORD para Windows e FITOPAC (Shepherd, 1995).

Para realização dessas análises foi elaborada uma matriz contendo o número de indivíduos de cada espécie em cada parcela de cada unidade ecológica, contendo todas as formas de vida. Essa matriz foi utilizada para obter os coeficientes de similaridade.

A homogeneização do tamanho das parcelas foi obtida através da transformação das parcelas de $20 \mathrm{~m}^{2}$ em parcelas de $100 \mathrm{~m}^{2}$. No caso das clareiras, foram consideradas apenas as que tinham valores próximos de $100 \mathrm{~m}^{2}$, que resultou em 4 clareiras das 10 apresentadas no trabalho de Martins (1999). 
As diferenças de metodologia de inclusão de indivíduos na amostragem dos vários trabalhos foram amenizadas através da eliminação das espécies que apresentaram menos de 10 individuos amostrados, somando-se todas as parcelas das diferentes unidades ecológicas. Esse processo teve como objetivo a eliminação das espécies com baixa densidade populacional, as quais ocasionalmente não puderam ser amostradas devido a uma insuficiência amostral ou às diferentes metodologias de amostragem.

O resultado dessas análises descritas no item 4.5. (similaridade vegetacional entre as unidades ecológicas) apresentou as variações entre cada parcela, revelando a similaridade ou dissimilaridade entre elas e consequentemente entre as unidades ecológicas. 


\section{RESULTADOS E DISCUSSÃO}

\subsection{Definição da legenda usada para as unidades ecológicas}

Inicialmente foi definida uma legenda provisória contendo o maior número possível de unidades ecológicas com provável existência no fragmento estudado. Essas primeiras unidades ecológicas foram definidas com base no conhecimento da área, nas primeiras visitas de campo para reconhecimento e checagem de padrões, e através da comparação com as fotografias aéreas e da bibliografia já disponivel sobre a vegetação da referida área. Essa legenda previamente definida continha 10 unidades ecológicas, as quais são apresentadas na Tabela 6 .

A legenda definitiva foi elaborada após a checagem de campo das unidades ecológicas identificadas nas imagens geradas da fotointerpretação, resultando na reavaliação da legenda previamente proposta.

Tabela 6 - Legendas usadas no trabalho da Reserva Municipal de Santa Genebra, Campinas, SP.

\begin{tabular}{|l|l|}
\hline Legenda previamente definida & Legenda atual \\
\hline Ȧreas sem indícios de perturbação recente & Areas sem indícios de perturbação recente \\
\hline Areas com indícios de perturbação recente & \multirow{2}{*}{ Áreas com indícios de perturbação recente } \\
\hline Extração seletiva & \\
\hline Floresta de encosta & Faixa com efeito de borda \\
\hline Faixa com efeito de borda & Area queimada \\
\hline Área queimada & \multirow{2}{*}{ Floresta paludosa } \\
\hline Complexo ciliar (floresta ripária) & Maciço de Maria-preta \\
\hline Floresta paludosa & Clareiras grandes \\
\hline Dossel emergente (dossel elevado) &
\end{tabular}


A reavaliação da legenda resultou na união de algumas unidades ecológicas que foram inicialmente interpretadas como sendo possíveis unidades distintas, mas que apresentaram-se com mesma característica florística e estrutural.

As unidades ecológicas do "complexo ciliar" (floresta ripária) e da "floresta paludosa" (floresta de brejo), foram reunidas e denominadas apenas como floresta paludosa. Isso ocorreu devido à constatação em campo de inundação permanente e a semelhança florística e estrutural nessas áreas, com espécies adaptadas a essa condição de encharcamento ao longo de toda extensão dessas unidades.

As unidades ecológicas "áreas com indícios de perturbação recente", "floresta de encosta" e "extração seletiva" apresentaram diferenças fisionômicas na classificação das imagens, mas não mostraram diferenças florísticas e estruturais durante a checagem de campo. Segundo Rodrigues et al. (1998), a característica fisionômica por si só pode não refletir numa correlação direta com a composição florística, podendo uma mesma unidade ecológica apresentar mais de um perfil fisionômico em função de fatores diversos. Do mesmo modo, essas classificações não puderam ser consideradas errôneas em relação às diferenças fisionômicas; no entanto, não possuíam correlação direta com as unidades ecológicas.

Nesse caso, essas três unidades ecológicas foram agrupadas, formando uma só, tendo sido consideradas na legenda apenas como "áreas com indícios de perturbação recente". Um dos motivos para essa união foi o fato da unidade anteriormente considerada como "floresta de encosta" não ter apresentado a declividade acentuada que aparentava nas análises das imagens, não caracterizando-se como unidade ecológica própria. Da mesma forma, o amadurecimento sucessional da área anteriormente considerada como "extração seletiva" em função das fotografias aéreas e imagens orbitais terem aproximadamente 5 anos, não permitiu a sua separação florística e estrutural daquela unidade entitulada de "áreas com indícios de perturbação recente".

Outra dificuldade foi a localização das clareiras da unidade anteriormente chamada de "clareiras grandes e pequenas" em campo. Na verdade, foram constatados erros de fotointerpretação dessa unidade por ter sido considerado que todas as áreas com 
tons escuros (próximos do preto) no interior da floresta fossem áreas com vegetação herbácea ou arbustiva, representando as clareiras. Essas áreas com tons escuros nem sempre representaram clareiras, mas as vezes o resultado do sombreamento causado por árvores de grande porte (emergentes) no estrato inferior da floresta, não necessariamente se definindo como uma clareira. Também deve ser ressaltado que devido à fotointerpretação ter sido realizada em fotografias de 1994, muitas dessas clareiras já estavam reocupadas por vegetação arbórea, mesmo que de grupos ecológicos mais iniciais da sucessão, ao mesmo tempo que outras novas clareiras foram abertas. Isso dificultou a localização dessas unidades (clareiras) no campo, devidos aos fatores já descritos anteriormente e principalmente ao tamanho relativamente reduzido dessas clareiras, conflitando com a resolução espacial das imagens usadas para o zoneamento. Além é claro da dificuldade de deslocamento dentro dessas áreas, geralmente bastante perturbadas, tornando inviável qualquer tentativa de checagem e mapeamento de todas as clareiras delimitadas em mapa na área total de 252 ha. Neste caso, optou-se por apresentar em mapa apenas as clareiras de maior tamanho, denominadas na legenda de "clareias grandes".

Nas imagens orbitais, a unidade ecológica "área queimada" que se apresentava classificada junto com a unidade "faixa com efeito de borda", foi reclassificada com base nos conhecimentos adquiridos no campo durante a checagem.

\subsection{Resultados da análise de imagens aerofotográficas}

Nesse item, são apresentados os três métodos usados para análise das fotografias aéreas, sendo eles: a análise analógica, com a utilização de estereoscópio de espelhos; a análise analógica de fotografia aérea em formato digital, com auxílio do programa Adobe Photoshop 3.0; e a análise digital pelo ER Mapper 5.2, usando classificações texturais. 


\subsubsection{Análise analógica das imagens aerofotográficas}

A análise analógica (visual) para as fotografias aéreas de julho de 1972, junho de 1978, junho de 1994 e dezembro de 1994, nas respectivas escalas 1:25.000, 1:35.000, 1:25.000 e 1:5.000, foi feita por meio de estereoscopia, obtendo resultados diferenciados em relação às escalas estudadas.

O mapa produzido pela análise das fotografias na escala 1:5.000, do ano de 1994, obteve o melhor detalhamento em relação ao número de classes, onde foi possível observar 7 unidades ecológicas legendadas. Esse mapa, apresentou duas porções disjuntas chamadas de "A" e "B" na Figura 4, sendo a porção "A" correspondente à ponta localizada no extremo oeste da floresta, trecho esse que foi queimado em 1981. A parte "B", referente à parte central e leste da floresta, que representa a maior parte do fragmento e possui a maior parte das unidades ecológicas identificadas. A porção norte da Reserva não foi fotografada.

A Figura 4 apresentou a maior parte da Reserva recoberta pelas unidades ecológicas "áreas com indícios de perturbação recente", sendo que a "área sem indícios de perturbação recente" apareceu como a segunda maior unidade. A faixa com efeito de borda apresentou-se bem intensificada na face nordeste da floresta e praticamente se ausentando nas faces sudoeste e sudeste. Foi possível também demarcar as "clareiras grandes", a "floresta paludosa" (floresta de brejo), a "área queimada" e o "maciço de maria-preta (Diatenopteryx sorbifolia Radlk.)".

A possibilidade de identificação e separação das "clareiras grandes" e das "áreas sem indícios de perturbação recente" e "áreas com indícios de perturbação recente", diferenciou essa análise em escala 1:5.000 das outras com escalas menores, que não conseguiram separar essas três unidades, ficando agrupadas numa única classe.

Os mapas produzidos pelas análises das imagens aéreas dos anos de 1972 e 1978, com escala 1:25.000 e 1:35.000 respectivamente, identificaram apenas 5 das 7 unidades vegetacionais, sendo que algumas unidades não puderam ser separadas, ficando agrupadas numa mesma classe. As classes identificadas foram: 1) floresta paludosa 2) as 
áreas com indícios de perturbação recente, incluindo as áreas com evidências de corte seletivo; 3) faixa com efeito de borda; 4) maciço de maria-preta (Diatenopteryx sorbifolia Radlk.) e; 5) áreas com e sem indícios de perturbação recente, clareiras e algumas matas de brejo (Figuras 5 e 6 ).

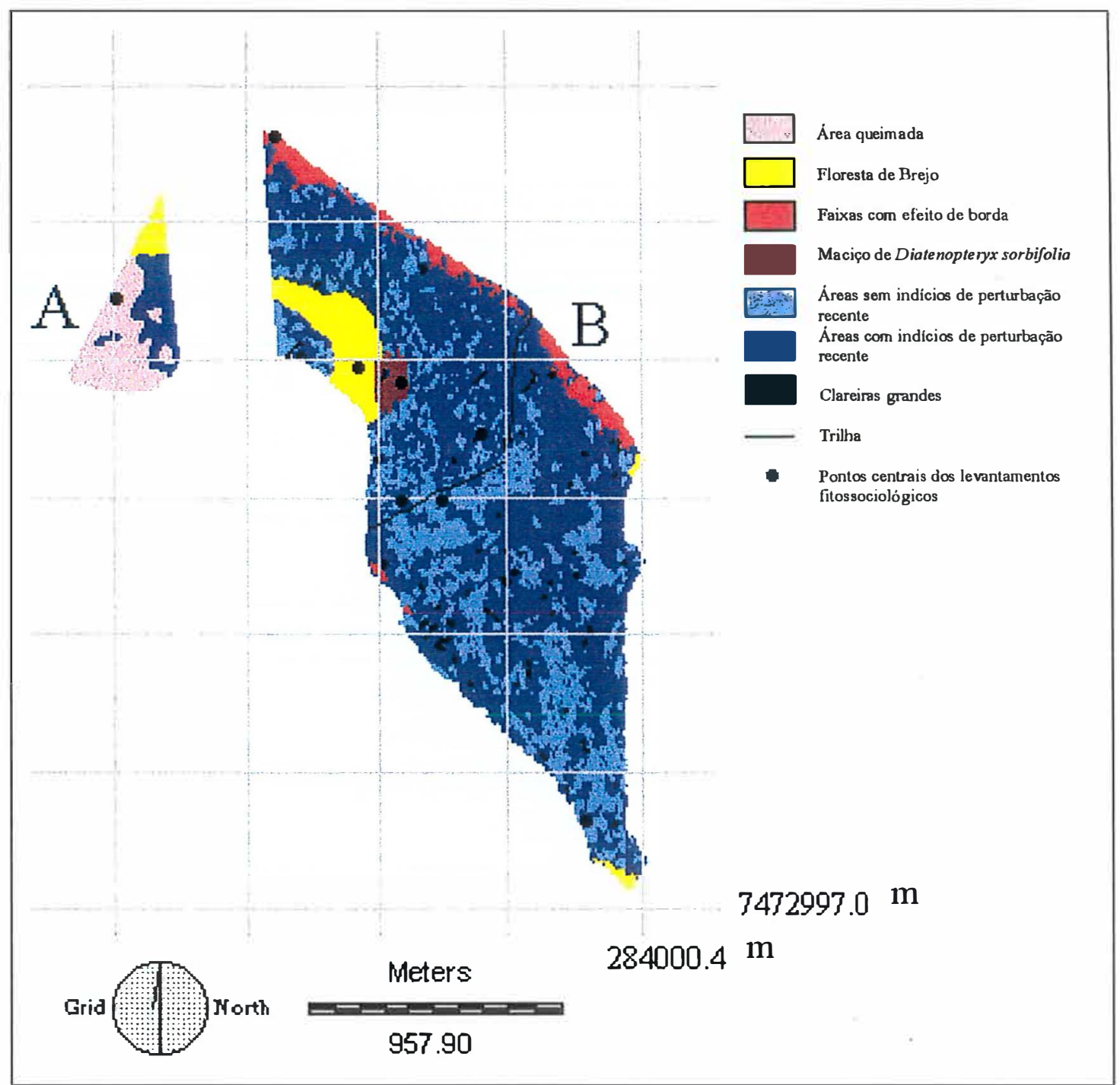

Figura 4 - Mapa da Reserva Municipal de Santa Genebra, Campinas SP, com as unidades ecológicas obtidas através de estereoscopia das fotografias aéreas de 1994 (escala $1: 5.000)$. 
Na análise feita para o ano de 1972, a unidade "faixa com efeito de borda" mostrou-se ainda muito restrita, limitando-se a trechos da borda na face nordeste da Reserva. O mapa apresentou também áreas com grandes perturbações antrópicas, onde houve a retirada seletiva de madeiras.

O mapa produzido a partir das análises das fotografias aéreas de 1978, apesar de ter apresentado as mesmas unidades ecológicas do mapa referente ás fotografias do ano de 1972, mostrou uma área maior de influência da faixa com efeito de borda na face nordeste da Reserva e uma redução parcial do trecho com indício de extração seletiva de madeira, que pode significar uma recuperação desse trecho no período de seis anos (1972 - 1978).

O mapa produzido pela análise da fotografia aérea do ano de 1994 , na escala 1:25.000, apresentou 5 situações distintas, sendo que algumas unidades ecológicas inicialmente identificadas também não puderam ser separadas, encontrando-se em uma mesma classe. As classes identificadas foram: 1) floresta paludosa; 2) área queimada; 3) faixas com efeito de borda; 4) maciço de maria-preta (Diatenopteryx sorbifolia Radlk.); 5) áreas com e sem indícios de perturbação recente, clareiras grandes e algumas matas de brejo (Figura 7).

Esse mapa apresentou um trecho diferenciado chamado na legenda de área queimada, onde ocorreu o incêndio em 1981. Esse trecho não apareceu nas análises das fotografias de 1972 e 1978, que por sua vez apresentaram um trecho com indícios de perturbação recente e retirada seletiva de madeira, não sendo mais identificado na fotografia de 1994 devido ao avanço sucessional. O mapa mostrou ainda um significativo aumento da faixa do efeito de borda na face nordeste da Reserva. (ver item 4.8. "Análise temporal das fotografias aéreas"). 

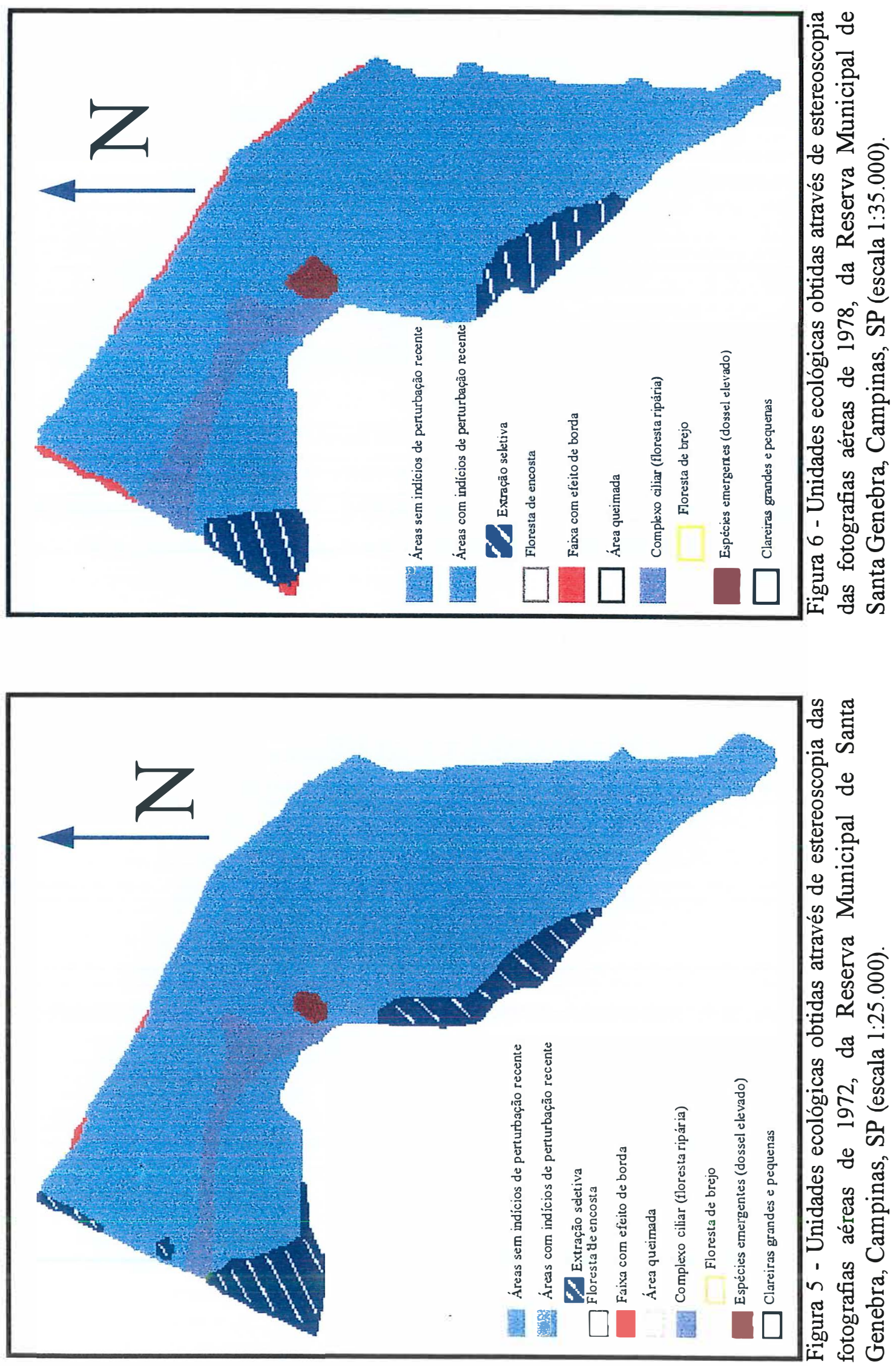


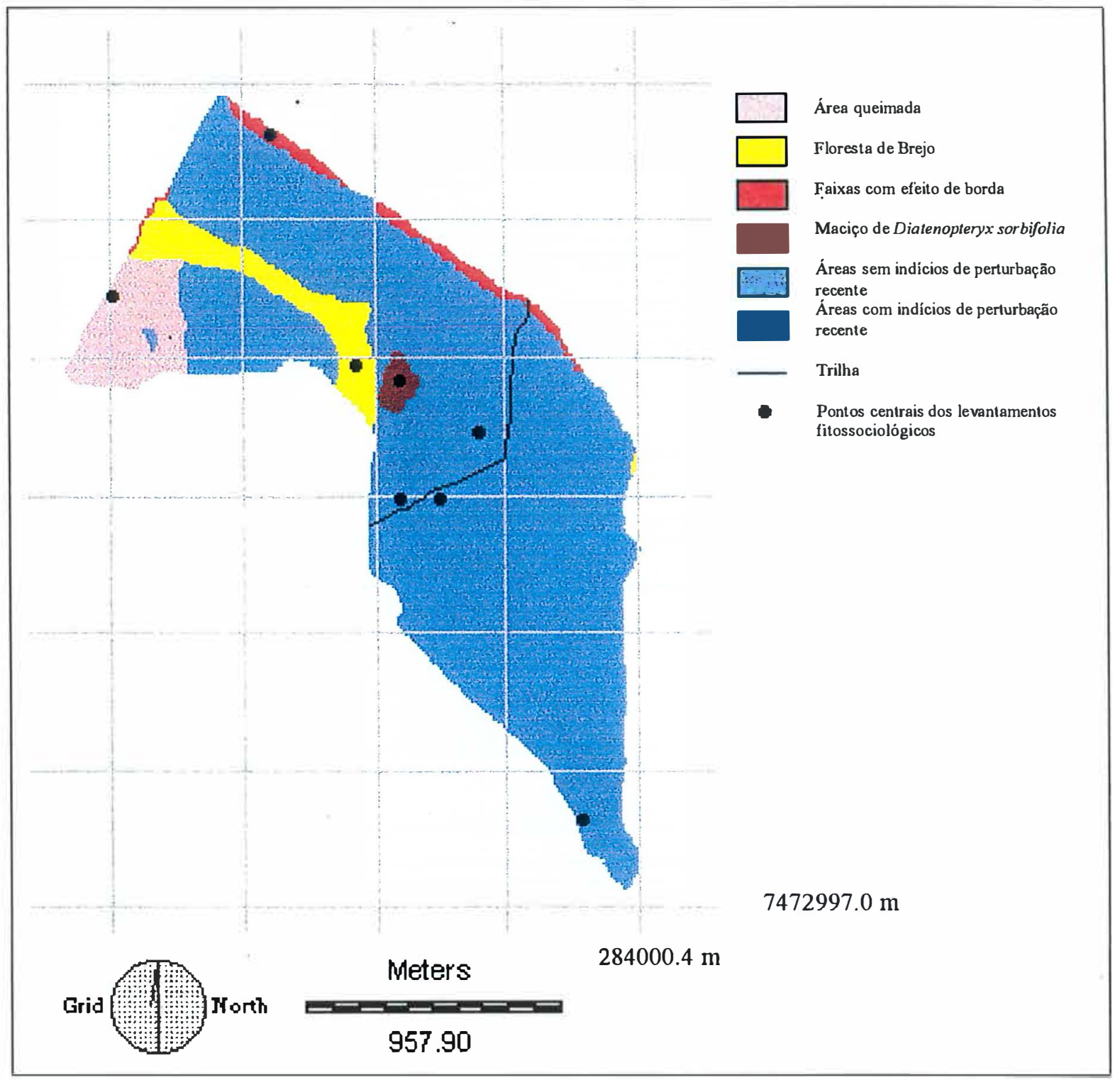

Figura 7 - Mapa da Reserva Municipal de Santa Genebra, Campinas, SP, com as unidades ecológicas obtidas através de estereoscopia das fotografias aéreas de 1994 (escala 1:25.000).

\subsubsection{Análise visual de fotografia aérea em formato digital}

A análise visual de fotografia aérea em formato digital foi realizada usando a fotografia na escala 1:25.000 do ano de 1994 . 
Nessa análise foram observadas as 7 unidades ecológicas legendadas, sendo que também foi possível a identificação das "clareiras grandes", "áreas sem indícios de perturbação recente" e "áreas com indícios de perturbação recente" (Figura 8).

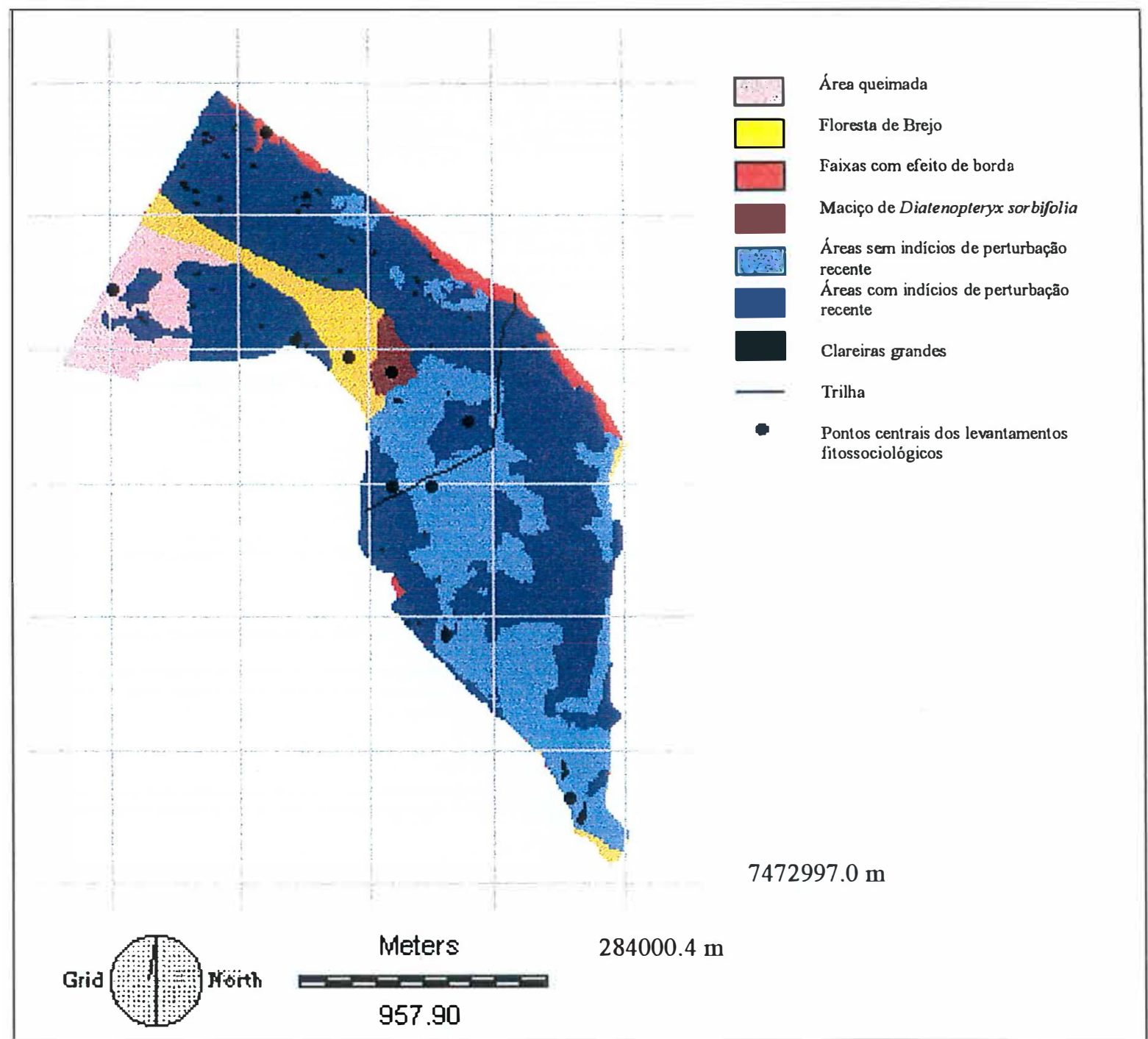

Figura 8 - Mapa da Reserva Municipal de Santa Genebra, Campinas, SP, com as unidades ecológicas obtidas através da análise visual de fotografia aérea digital (mapa obtido através da escanerização e análise da fotografia aérea de 1994, escala 1:25.000).

O mapa produzido mostrou a diversidade de fisionomias existentes na Reserva Municipal de Santa Genebra, onde predominavam as áreas com indícios de perturbação 
recente, seguida das áreas sem indícios de perturbação recente, que ocupam o segundo lugar em tamanho.

Nota-se uma maior concentração das áreas com indícios de perturbação recente nas partes periféricas da Reserva, que estão ocorrendo possivelmente devido às atividades agrícolas do entorno, que geram ações de perturbação como descarga de águas superficiais, efeito de pesticidas etc. e/ou as antigas retiradas seletivas de madeira que não chegavam a atingir com a mesma intensidade o núcleo da Reserva. As faixas com efeito de borda foram novamente bem evidenciadas na face nordeste da floresta e praticamente ausentes da sudeste e da sudoeste.

Para esse método, a utilização de uma fotografia aérea em escalas maiores, como 1:5.000 fica atualmente inviabilizada para uso em microcomputadores, pelo tamanho do arquivo gerado com a escanerização em alta resolução (próximo a 1000 dpi) das fotografias que compõem a Reserva. Uma fotografia aérea $(23 \mathrm{~cm} \times 23 \mathrm{~cm})$ escanerizada em apenas 16 níveis de cinza, ocuparia aproximadamente $40 \mathrm{MB}$ de memória. No entanto, com a rápida modernização dos microcomputadores, em breve deverá ser viável trabalhar com esses arquivos.

A ampliação da imagem no programa de edição e tratamento de imagens Adobe Photoshop 3.0, possibilitou uma melhor percepção de altura do dossel e largura das copas dos indivíduos arbóreos da floresta, em comparação ao método de estereoscopia usado para essa mesma escala. Isso ocorre em função do limite de ampliação da imagem no estereoscópico, que não possibilita a separação de algumas unidades ecológicas, apesar de apresentar efeito tridimensional. Essa técnica de análise digital permitiu, além da ampliação usando os recursos de zoom, o uso de recursos de realce da imagem, que facilitam bastante a caracterização e o reconhecimento das unidades ecológicas.

A classificação de unidades ecológicas através do método de fotointerpretação visual, pode resultar em variações no tamanho e na forma dessas unidades, em função de parâmetros como: experiência do fotointérprete, condições de trabalho e principalmente a não existência de uma definição clara entre os limites de uma unidade para outra. Até mesmo usando a escala 1:5.000, a definição dos limites das unidades ecológicas continua 
subjetiva, como também é a delimitação dessas unidades ecológicas no próprio campo, mas certamente com precisões mais acuradas para essa escala.

\subsubsection{Classificação textural da imagem aerofotográfica digital}

Após vários testes usando diversos parâmetros de entrada no GLCM, foram escolhidos os melhores entre cada um dos descritores texturais para serem utilizados no algorítmo de classificação não supervisionada. Vale ressaltar que nessa análise, em nenhum dos testes utilizando o medidor textural "entropia" obteve-se um resultado satisfatório para ser incluído na classificação. Os parâmetros foram relacionados na Tabela 7, para cada um dos medidores usados.

Tabela 7 - Parâmetros de entrada no GLCM de cada uma das bandas texturais escolhidas para classificação não supervisionada, extraídas da fotografia aérea de 1994, em escala 1:5.000, da Reserva Municipal de Santa Genebra, Campinas, SP.

\begin{tabular}{|l|c|c|c|c|}
\hline Descritor & $\begin{array}{l}\text { Tamanho da } \\
\text { janela }\end{array}$ & $\begin{array}{l}\text { Nivel de } \\
\text { cinza }\end{array}$ & $\begin{array}{l}\text { Distância de } \\
\text { deslocamento }\end{array}$ & $\begin{array}{l}\text { Orientação da } \\
\text { co-ocorrência }\end{array}$ \\
\hline Contraste & $5 \times 5$ & 8 & 3 & $0^{\circ}$ \\
\hline Dissimilaridade & $5 \times 5$ & 8 & 3 & $0^{\circ}$ \\
\hline Homogeneidade & $5 \times 5$ & 8 & 3 & $0^{\circ}$ \\
\hline Momentos Inversos 1 a ordem & $5 \times 5$ & 8 & 3 & $0^{\circ}$ \\
\hline Momentos Inversos 2 ${ }^{\text {a }}$ ordem & $5 \times 5$ & 8 & 3 & $0^{\circ}$ \\
\hline Momentos Inversos 3 ${ }^{\text {ordem }}$ & $5 \times 5$ & 8 & 3 & $0^{\circ}$ \\
\hline Probabilidade Máxima & $5 \times 5$ & 2 & 3 & $0^{\circ}$ \\
\hline Média & $5 \times 5$ & 8 & 3 & $0^{\circ}$ \\
\hline Momentos 1 ${ }^{\text {o }}$ ordem & $5 \times 5$ & 8 & 3 & $0^{\circ}$ \\
\hline Momentos 2 ${ }^{\text {ordem }}$ & $5 \times 5$ & 8 & 3 & $0^{\circ}$ \\
\hline Momentos 3 ordem & $5 \times 5$ & 8 & 3 & $0^{\circ}$ \\
\hline Desvio-Padrão & $5 \times 5$ & 2 & 3 & $0^{\circ}$ \\
\hline Uniformidade & $5 \times 5$ & 2 & 3 & $0^{\circ}$ \\
\hline
\end{tabular}

Os resultados da classificação textural da fotografia aérea não tiveram nenhum tipo de correspondência com a localização das unidades ecológicas em campo. Entretanto, o classificador mostrou-se eficiente na separação da floresta e áreas 
cultivadas. A Figura 9 apresentou o resultado da classificação textural da fotografia aérea.

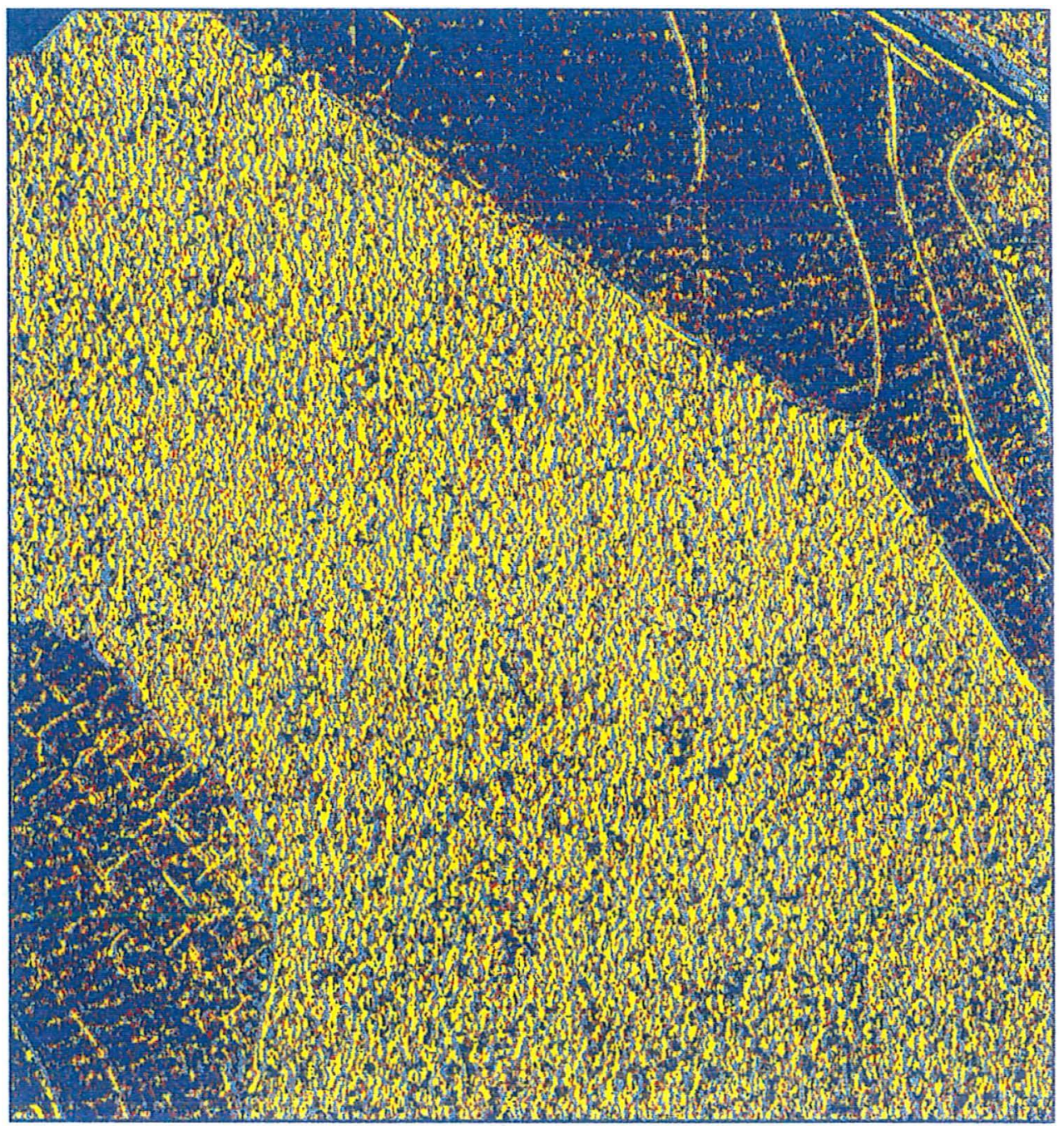

Figura 9 - Análise textural usando o algorítmo GLCM em imagem aérea no formato digital, de 1994, escala 1:5.000, da Reserva Municipal de Santa Genebra, Campinas, SP. 


\subsection{Resultados da análise de imagens orbitais}

\subsubsection{Classificação espectral}

Baseado nas checagens de campo e nas fotografias aéreas da Reserva, os resultados obtidos através do classificador não supervisionado mostraram-se animadores, principalmente quanto ao número de unidades identificadas e suas limitações no campo. Usando esse mesmo classificador não supervisionado, Stenback \& Congalton (1990), tiveram bons resultados na análise de quatro classes de floresta de coníferas.

$\mathrm{Na}$ imagem Landsat, a melhor classificação foi obtida com a indicação de 18 classes no parâmetro de entrada (número máximo de classes), sendo que dentro da Reserva foram obtidas inicialmente 4 classes. Para a imagem SPOT a melhor classificação foi obtida com um número máximo de 16 classes, sendo que este, também resultou em 4 classes dentro do fragmento estudado.

As imagens dos dois sensores tiveram resultados semelhantes no sentido da representação de unidades ecológicas pelas classes obtidas, ou seja, cada uma das 4 classes obtidas nas duas imagens temáticas (Landsat e SPOT) englobaram as mesmas unidades ecológicas, apesar de ter existido diferenças quanto à resolução espacial e à localização dos limites dessas classes em cada uma das imagens. As Figuras 10 e 11,

apresentam as classificações não supervisionas das imagens Landsat e SPOT antes de serem reclassificadas analogicamente.

Uma das classes identificadas englobou as unidades ecológicas "faixa do efeito de borda" e "área queimada" e embora tenham sido classificadas pelo classificador não supervisionado como sendo uma mesma unidade, foram reclassificadas posteriormente com base nas checagens de campo (Figuras 12 e 13). 

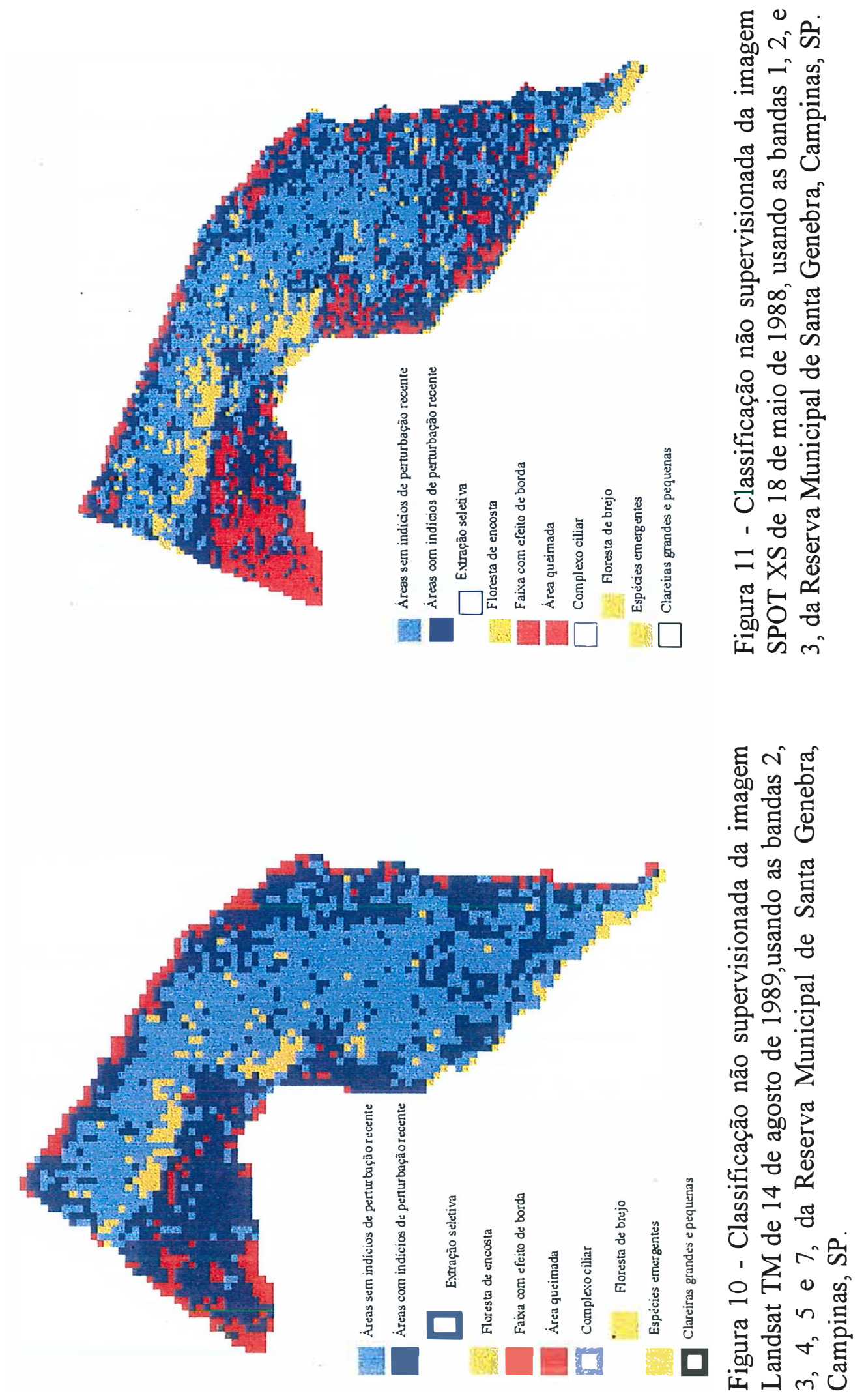
Outra classe identificada nesse método, engloba as unidades ecológicas "maciço de maria-preta (Diatenopteryx sorbifolia Radlk.)", trechos de floresta paludosa e uma faixa na borda da face sudoeste da Reserva e foram resultantes do sombreamento que foi pronunciado nesses trechos e observado em todas as fotografias aéreas.

Essa classe apresentou também trechos no interior da Reserva. As duas outras classes restantes foram as "áreas com indícios de perturbação recente" e "áreas sem indícios de perturbação recente", englobando a área de floresta paludosa, que não pode ser classificada separadamente dessas duas unidades.

Nas imagens orbitais classificadas, principalmente a do satélite SPOT, as áreas classificadas como "faixa com efeito de borda" misturam-se com as "áreas com indícios de perturbação recente" e, segundo a checagem de campo, provavelmente estão relacionadas com a grande presença de clareiras e bambuzais nessa área, sendo detectadas devido a uma melhor resolução espacial do sensor SPOT.

Nesses mesmos resultados das análises em imagens orbitais apenas pequenos trechos da unidade ecológica "florestas de brejo" foram classificados diferencialmente, sendo a maior parte desta formação classificada erroneamente como "áreas com indícios de perturbação recente" (Figuras 12 e 13).

Em geral essas classificações orbitais apresentaram resultados interessantes no sentido de detectar a variação do gradiente sucessional dentro da Reserva. Somente esse resultado já fornece dados de grande importância no sentido de monitorar' os processos de dinâmica florestal, além de subsidiar informações relevantes para as propostas de conservação da Reserva. 


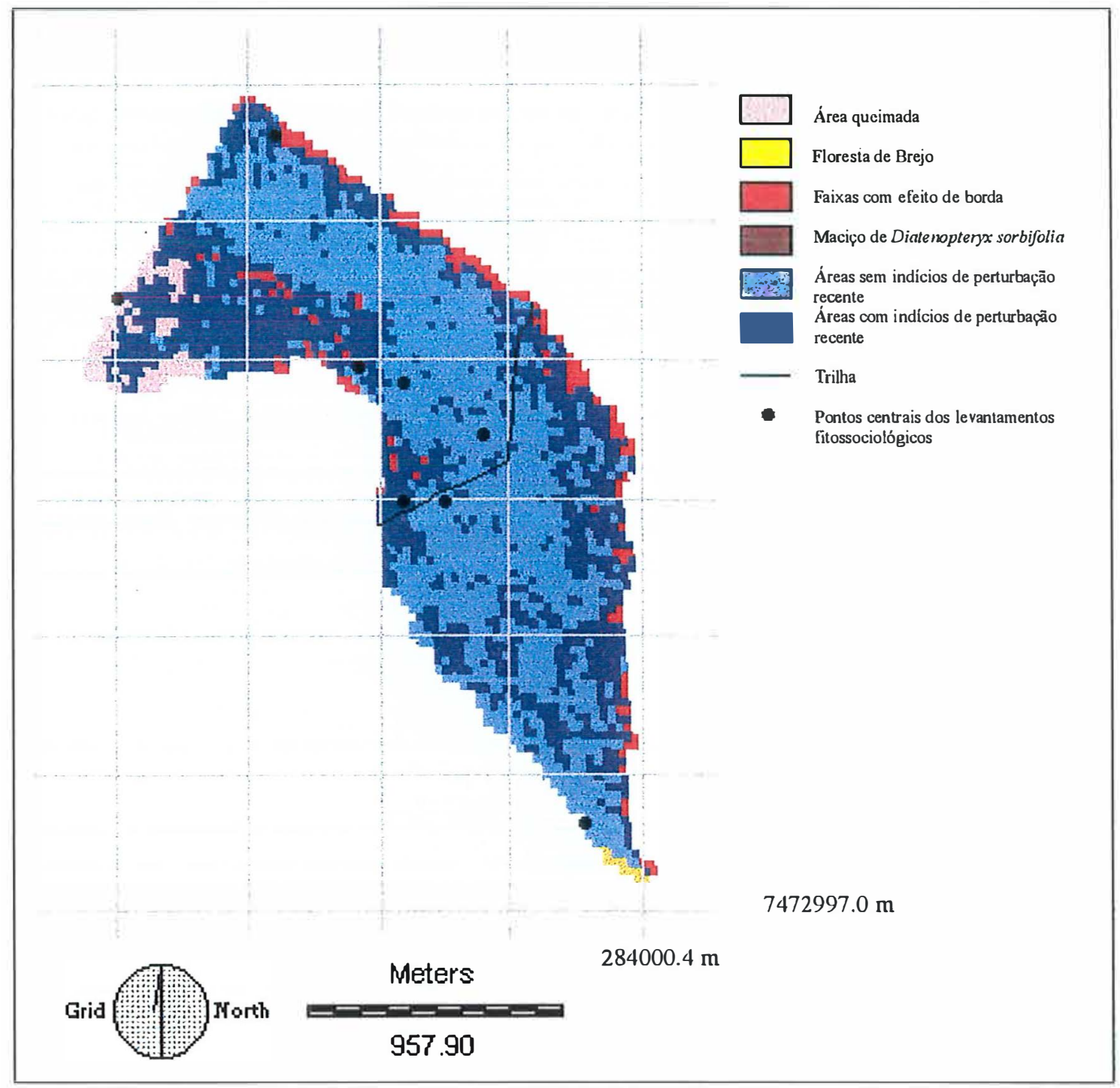

Figura 12 - Mapa da Reserva Municipal de Santa Genebra, Campinas, SP, com as unidades ecológicas obtidas através da classificação não supervisionada da imagem Landsat TM, de 14 de agosto de 1989, usando as bandas 2, 3, 4, 5 e 7 . 


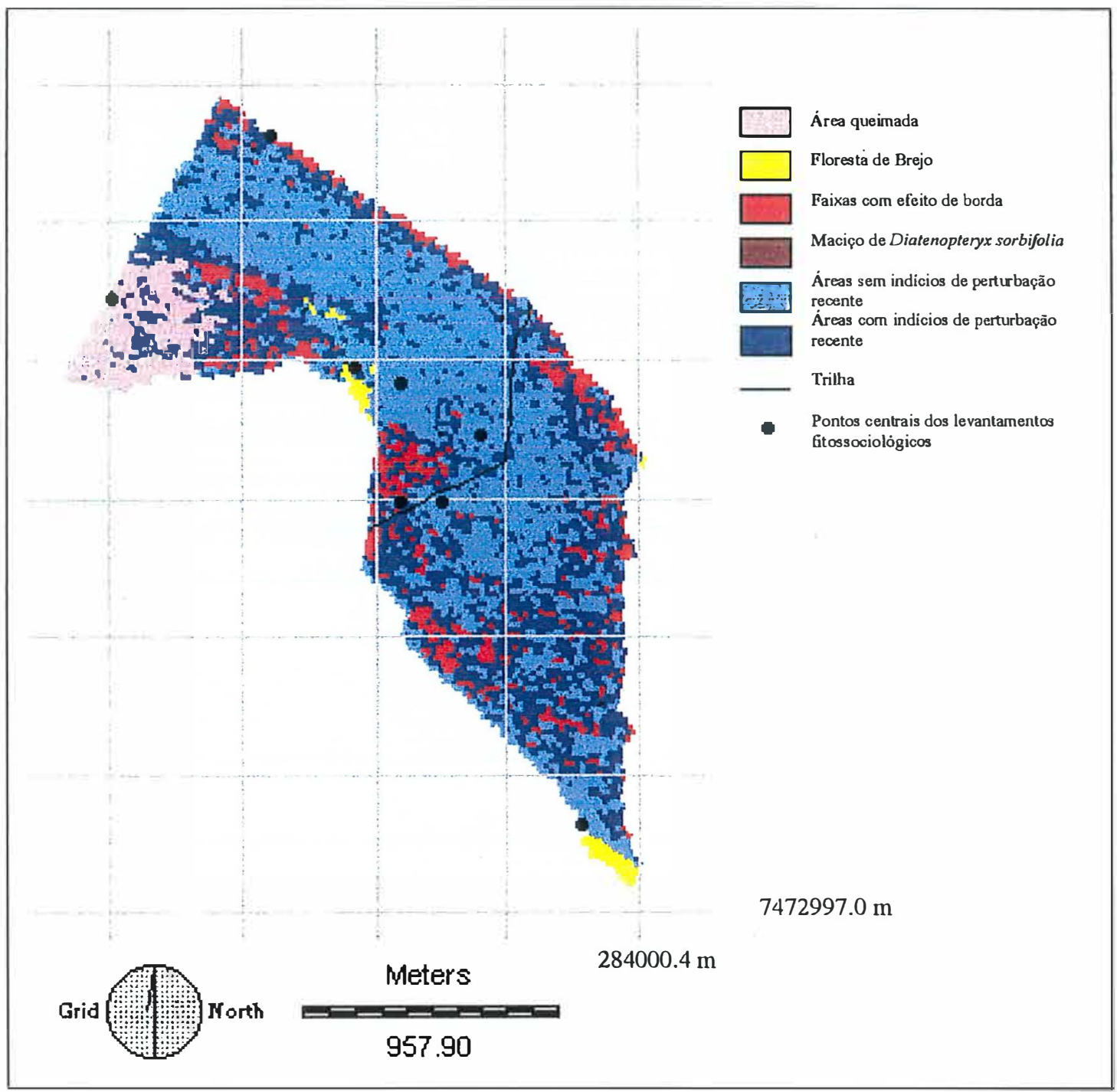

Figura 13 - Mapa da Reserva Municipal de Santa Genebra, Campinas, SP, com as unidades ecológicas obtidas através da classificação não supervisionada da imagem SPOT XS, de 18 de maio de 1988, usando as bandas 1,2 , e 3 .

\subsubsection{Classificação textural e espectral/textural das imagens Landsat e SPOT}

Seguindo basicamente a mesma metodologia usada para fotografia aérea, vários testes foram utilizados exaustivamente usando diversos parâmetros de entrada no GLCM. Os melhores resultados entre cada um dos descritores texturais foram escolhidos para serem 
utilizados no algorítmo de classificação não supervisionada. Alguns descritores texturais não obtiveram resultados considerados suficientemente bons para serem incluídos na classificação sendo, portanto, excluídos desse processo.

Os parâmetros utilizados foram relacionados na Tabela 8 e 9 para cada um dos descritores, sendo incluídos na classificação, nas imagens Landsat e SPOT, respectivamente.

Apesar dos esforços realizados através de muitos testes usando os medidores texturais, os resultados das classificações foram considerados insatisfatórios, tanto nas classificações texturais quanto nas texturais/espectrais. Isso ocorreu devido a discrepância dos resultados dessas classificações em relação aos conhecimentos sobre a verdade terrestre da Reserva. Dessa forma, as classes obtidas não puderam ser associadas a nenhuma das unidades ecológicas da floresta.

Tabela 8 - Parâmetros de entrada no GLCM de cada uma das bandas texturais escolhidas para classificação não supervisionada, extraídas da imagem Landsat TM banda 4, de 14 de agosto de 1989, da Reserva Municipal de Santa Genebra, Campinas, SP.

\begin{tabular}{|l|c|c|c|c|}
\hline Descritor & $\begin{array}{l}\text { Tamanho da } \\
\text { janela }\end{array}$ & $\begin{array}{l}\text { Nivel de } \\
\text { cinza }\end{array}$ & $\begin{array}{l}\text { Distância de Orientação da } \\
\text { deslocamento }\end{array}$ & \begin{tabular}{c} 
co-ocorrência \\
\hline Contraste
\end{tabular} \\
\hline Dissimilaridade & $15 \times 15$ & 2 & 1 & $0^{\circ}$ \\
\hline Homogeneidade & $15 \times 15$ & 4 & 1 & $0^{\circ}$ \\
\hline Momentos Inversos 2a ordem & $15 \times 15$ & 2 & 1 & $0^{\circ}$ \\
\hline Probabilidade Máxima & $15 \times 15$ & 2 & 1 & $0^{\circ}$ \\
\hline Média & $15 \times 15$ & 2 & 1 & $0^{\circ}$ \\
\hline Momentos 2a ordem & $15 \times 15$ & 2 & 1 & $0^{\circ}$ \\
\hline Desvio-Padrão & $9 \times 9$ & 2 & 1 & $0^{\circ}$ \\
\hline Uniformidade & $15 \times 15$ & 2 & 1 & $0^{\circ}$ \\
\hline
\end{tabular}


Tabela 9 - Parâmetros de entrada no GLCM de cada uma das bandas texturais escolhidas para classificação não supervisionada, extraídas da imagem SPOT XS banda 3, de 18 de maio de 1988, da Reserva Municipal de Santa Genebra, Campinas, SP.

\begin{tabular}{|l|c|c|c|c|}
\hline Descritor & $\begin{array}{c}\text { Tamanho da } \\
\text { janela }\end{array}$ & $\begin{array}{c}\text { Nivel de } \\
\text { cinza }\end{array}$ & $\begin{array}{c}\text { Distância de } \\
\text { deslocamento }\end{array}$ & $\begin{array}{c}\text { Orientaçāo da } \\
\text { co-ocorrência }\end{array}$ \\
\hline Contraste & $7 \times 7$ & 4 & 1 & $0^{\circ}$ \\
\hline Dissimilaridade & $7 \times 7$ & 4 & 1 & $0^{\circ}$ \\
\hline Homogeneidade & $7 \times 7$ & 4 & 1 & $0^{\circ}$ \\
\hline Momentos Inversos de 2a ordem & $7 \times 7$ & 4 & 1 & $0^{\circ}$ \\
\hline Probabilidade Máxima & $7 \times 7$ & 4 & 1 & $0^{\circ}$ \\
\hline Média & $7 \times 7$ & 4 & 1 & $0^{\circ}$ \\
\hline Momentos de 2 ${ }^{\text {a }}$ ordem & $7 \times 7$ & 4 & 1 & $0^{\circ}$ \\
\hline Desvio-Padrão & $7 \times 7$ & 2 & 1 & $0^{\circ}$ \\
\hline Uniformidade & $7 \times 7$ & 4 & 1 & $0^{\circ}$ \\
\hline
\end{tabular}

Os resultados dessas análises texturais das imagens Landsat TM e SPOT XS e análises espectrais/texturais dos mesmos sensores são apresentados nas Figuras 14, 15, 16 e 17 , respectivamente. 

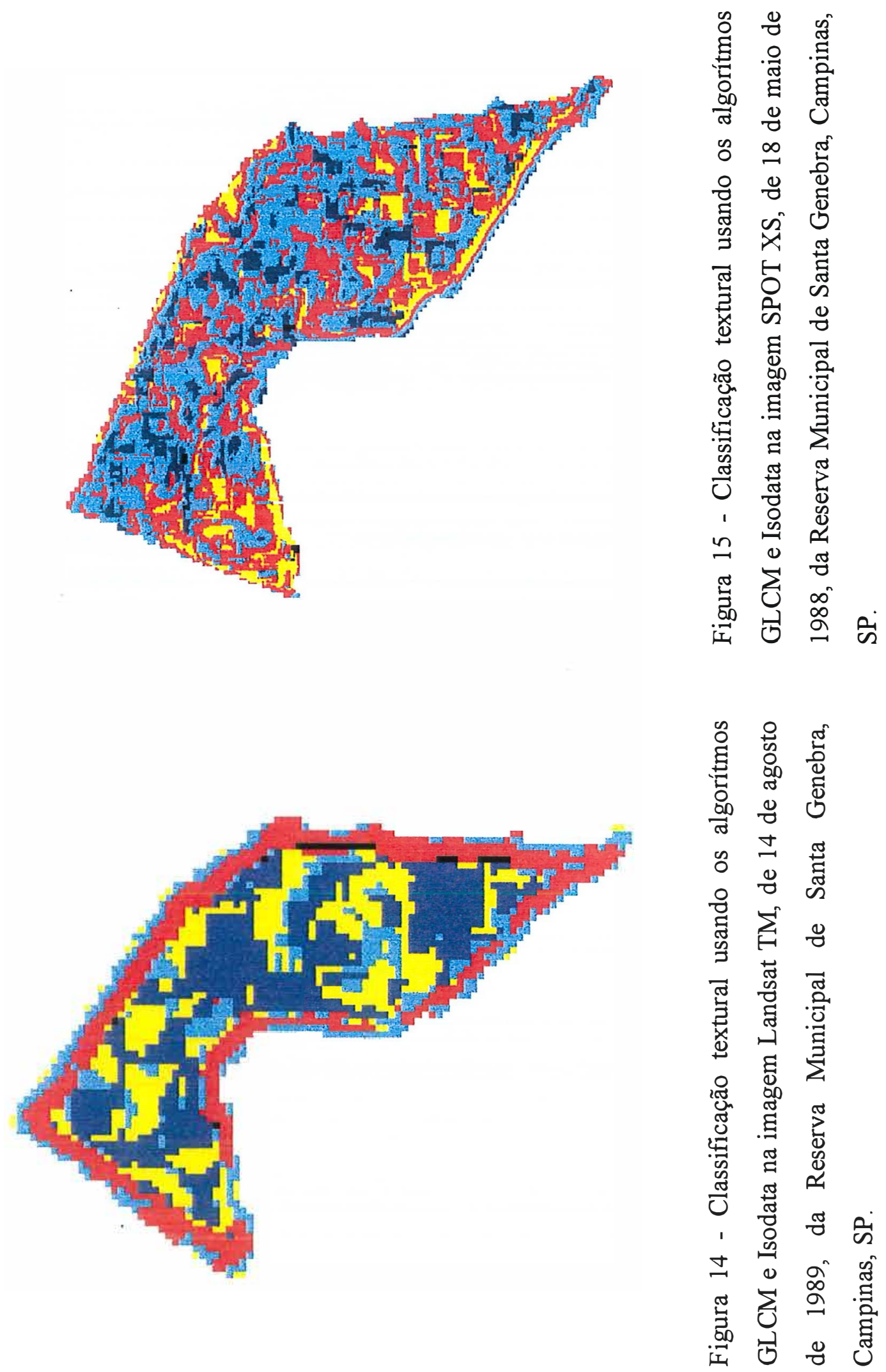

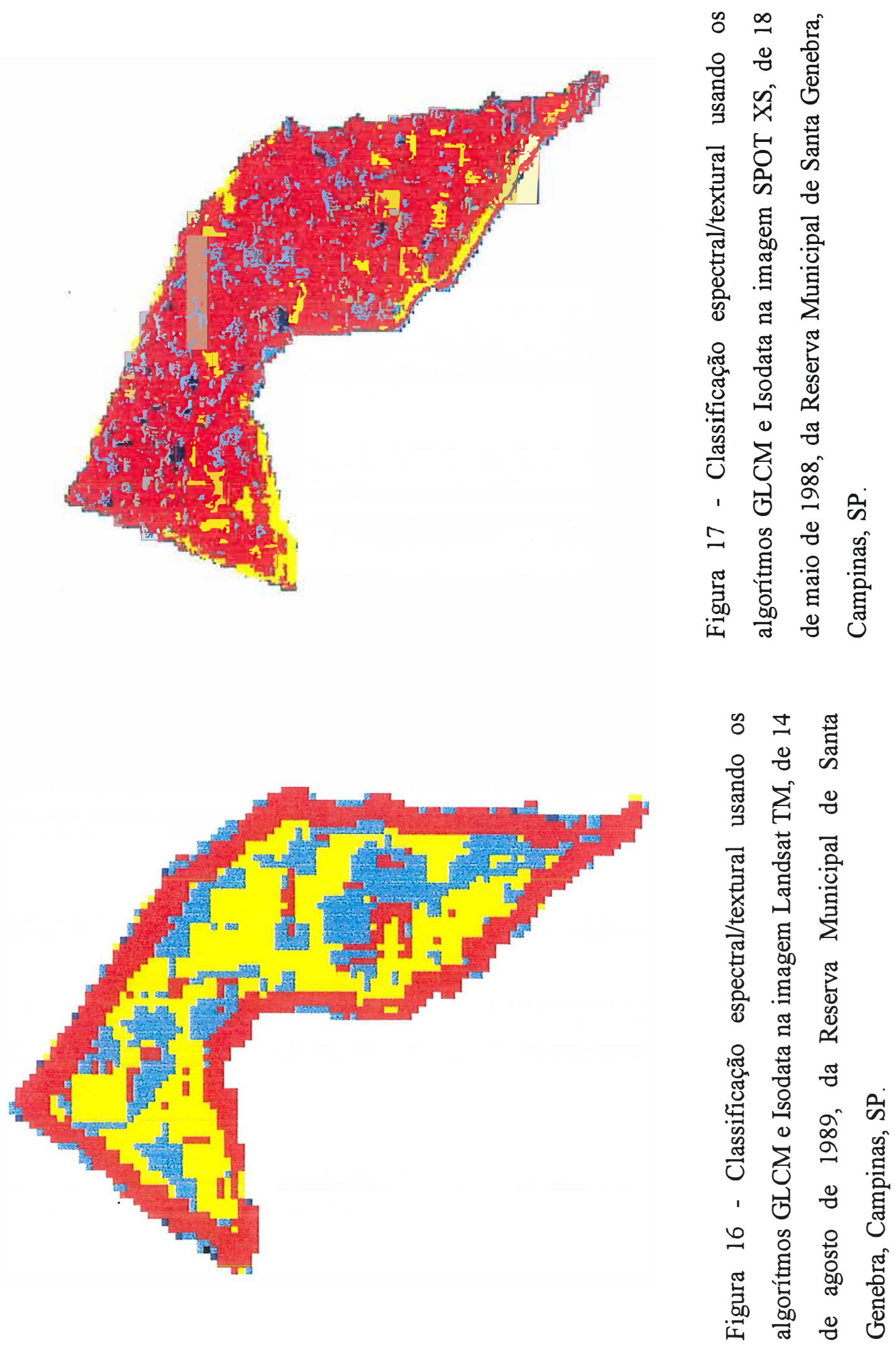


\subsection{Análise da exatidão das imagens classificadas}

O método de análise analógica em estereoscópio de espelhos usando fotografia aérea com escala 1:5.000 foi escolhido como referência terrestre (item 3.4. "análise da exatidão das imagens classificadas") para testar a exatidão das imagens classificadas em função de ter se destacado dos demais métodos utilizados. Quanto ao número de unidades ecológicas, este método juntamente com a análise analógica de fotografia aérea com imagem digital, reconheceu 7 unidades, ou seja, 2 a mais que os outros métodos utilizados.

No entanto, a maior evidência de uma melhor representação da verdade terrestre pelo método de análise analógica em estereoscópio de espelhos usando fotografia aérea com escala 1:5.000 foi o fato das unidades ecológicas "áreas com indícios de perturbação recente" e "áreas sem indícios de perturbação recente", terem sido representadas de maneira mais fragmentada que nos outros métodos.

A intensa fragmentação das unidades ecológicas no mosaico florestal na Reserva, já descrito por Gandolfi (1999), foi confirmado nas análises de agrupamentos apresentadas no item 4.5. (similaridade vegetacional entre as unidades ecológicas), onde algumas parcelas pertencentes a unidade "áreas com indícios de perturbação recente" foram agrupadas junto com as parcelas da unidade "áreas sem indícios de perturbação recente" e vice-versa. Isso demonstra a heterogeneidade vegetacional ocorrendo a curtas distâncias na área amostral, com várias situações ecotonais. Sendo assim, para essas unidades ecológicas, nenhum dos outros resultados demonstrou essa heterogeneidade ocorrendo em trechos da floresta de forma mais detalhada. Nos demais métodos a heterogeneidade foi apresentada de forma mais genérica, apenas demarcando as áreas onde predomina a unidade ecológica propriamente dita, mas não detalhando as variações de maturidade vegetacional dentro dessa unidade ecológica na Reserva.

Considerando então a classificação obtida através do método de análise analógica em estereoscópio de espelhos usando fotografia aérea com escala 1:5.000, de 1994, como representante da verdade terrestre, foram realizados os cruzamentos desses dados com as 
imagens classificadas. Vale a pena ressaltar, que nesses cruzamentos foi desprezado um pequeno trecho de floresta da Reserva, que não foi fotografado nessa escala.

Os cruzamentos dos dados foram realizados usando os seguintes resultados de classificação: classificação analógica de fotografia aérea em formato digital usando a escala 1:25.000, classificação analógica de fotografia aérea em estereoscópio usando a escala 1:25.000, classificação não supervisionada usando da imagem SPOT XS, classificação não supervisionada usando imagem Landsat TM. As imagens obtidas através da classificações das fotografias aéreas dos anos de 1972 e 1978 não foram usadas nesse cruzamento pela diferença temporal desses registros em relação a data da imagem tida como verdade terrestre (1994). Da mesma forma, as classificações texturais ou espectrais/texturais, não foram usadas pelas discrepâncias entre os seus resultados e o conhecimento adquirido na checagem no campo sobre a distribuição das unidades ecológicas na Reserva.

Através dos cruzamentos dos dados foram obtidas para cada uma das imagens classificadas as matrizes de erro, a exatidão global, o desempenho médio das classificações, os índices de concordância Kappa global e individual para cada unidade ecológica (Tabelas 10 à 21).

O desempenho médio das classificações foram menores quando comparados com o proposto por alguns autores para o cruzamento de resultados de fotointerpretação e com o recomendado pelo sistema de monitoramento utilizando dados de satélites (Aronoff, 1982b; Chen, 1996). Entretanto, deve-se levar em consideração a complexidade na obtenção da exatidão por diversos fatores envolvidos como: a influência da legenda temática; os procedimentos adotados para executar a georreferência das imagens; a variação temporal do uso das terras; delineamento e digitalização dos dados de referência terrestre; técnica de amostragem; conversões entre formatos, etc. (Shimabukuro, 1996). O uso de uma fotointerpretação como representante da verdade terrestre já traz erros devido a própria inconsistência humana. Isso ocorre especialmente para áreas muito heterogêneas em trechos com pequenas dimensões, como o mosaico florestal, onde as 
unidades ecológicas possuem dimensões pequenas e formas irregulares com faixa transicional entre as unidades (Shimabukuro, 1996).

De acordo com os resultados do índice de concordância Kappa global (Tabelas $12,15,18$ e 21 ), os resultados que obtiveram os maiores valores entre as classificações em ordem decrescente foram: a classificação analógica de fotografia aérea em formato digital usando a escala 1:25.000, seguida da classificação analógica de fotografia aérea em estereoscópio usando a escala 1:25.000 e posteriormente a classificação não supervisionada usando imagem SPOT XS e a classificação não supervisionada usando imagem Landsat TM.

Entretanto, em termos de desempenho médio das classificações, o método de classificação analógica de fotografia aérea em estereoscópio usando a escala 1:25.000 teve o pior desempenho com 34,94 \%. Isso se deve principalmente pela não diferenciação nesse método, das unidades ecológicas "áreas com indícios de perturbação recente" e "áreas sem indícios de perturbação recente" no mosaico sucessional de uma das unidades ecológicas identificadas com fisionomia florestal.

Nas classificações obtidas pelas fotografias aéreas, as matrizes de erro apresentadas pelas tabelas 10 e 13 mostram que a maior parte dos pixels classificados erroneamente pertencem as unidades ecológicas "área com indícios de perturbação recente", "área sem indícios de perturbação recente" e "faixa com efeito de borda". As duas primeiras unidades ecológicas citadas refletem a dificuldade de fotointerpretação nesses trechos devido as suas semelhanças fisionômicas, as suas pequenas dimensões e a fragmentação dessas unidades dentro da Reserva. Na análise de fotografias aéreas em estereoscópio de espelho usando escala 1:25.000 ou menores, elas não puderam ser distinguidas, sendo identificadas apenas como a unidade "área sem indícios de perturbação recente".

Os trechos da unidade ecológica "faixa com efeito de borda" foram representadas com área total bem menor que da imagem de referência, aumentando os erros de omissão para essa categoria. Isso provavelmente ocorreu pela maior facilidade de se interpretar 
essa categoria em escalas maiores, fazendo com que a imagem de referência apresentasse uma área maior para essa unidade na Reserva.

As matrizes de erro e o coeficiente Kappa das classificações realizadas com as imagens orbitais tiveram resultado semelhantes em relação a referência terrestre (Tabela 16 e 19). As unidades ecológicas que tiveram o maior número de pixels erroneamente classificados foram a "floresta de brejo" e a "faixa com efeito de borda", além do "maciço de Diatenopteryx sorbifolia Radlk.", sendo que este último nem chegou a ser classificado por esses métodos, resultando consequentemente em erro de omissão total para essa unidade. Nos dois resultados obtidos pela classificação das imagens orbitais, as unidades "floresta de Brejo" foram identificadas apenas em pequenos trechos, elevando consideravelmente os erros de omissão para essa unidade.

Em relação aos erros na unidade "faixa com efeito de borda" nas classificações das imagens orbitais, é compreensível que o classificador utilizando apenas a resposta espectral, tenha classificado essa categoria não apenas na borda do fragmento mas também no seu interior, onde se encontram áreas também igualmente degradadas (clareiras), dando uma resposta espectral semelhante. Essa classificação "errônea" realizada pelo classificador nas duas imagens orbitais, em sua maior parte coincidiu com a unidade ecológica "áreas com indícios de perturbação recente". Entretanto, a enorme variação da largura da faixa de influência do efeito de borda no entorno desse fragmento florestal não permitiu afirmar com exatidão quais desses pixels foram classificados erroneamente. O efeito de borda, dependendo da formação natural, pode ainda se pronunciar de maneira diferenciada (Jorge, 1995). 
Tabela 10 - Matriz de erro entre os dados da classificação analógica de fotografias aéreas em estereoscópio usando a escala 1:5.000, considerados como referência terrestre e da classificação analógica de fotografia aérea em formato digital usando a escala 1:25.000.

\begin{tabular}{|c|r|r|r|r|r|r|r|r|}
\hline Classes & \multicolumn{7}{|c|}{ Classes consideradas como a verdade terrestre } \\
\cline { 2 - 9 } mapeadas & 1 & 2 & 3 & 4 & 5 & 6 & Total & Erro C \\
\hline 0 & 54 & 35 & 84 & 178 & 4 & 0 & 355 & 1.0000 \\
\hline 1 & 874 & 0 & 68 & 103 & 0 & 59 & 1104 & 0.2083 \\
\hline 2 & 65 & 670 & 0 & 265 & 0 & 0 & 1000 & 0.3300 \\
\hline 3 & 7 & 0 & 2233 & 3333 & 18 & 1 & 5592 & 0.6007 \\
\hline 4 & 86 & 99 & 2184 & 6646 & 459 & 0 & 9474 & 0.2985 \\
\hline 5 & 1 & 0 & 26 & 104 & 256 & 0 & 387 & 0.3385 \\
\hline 6 & 0 & 0 & 42 & 118 & 0 & 153 & 313 & 0.5112 \\
\hline Total & 1087 & 804 & 4637 & 10747 & 737 & 213 & 18225 & \\
\hline Erro O & 0.1960 & 0.1667 & 0.5184 & 0.3816 & 0.6526 & 0.2817 & & 0.4057 \\
\hline
\end{tabular}

Erro O: erro de omissão (expresso em proporção); Erro C: erro de comissão (expresso em proporção); Classes de unidades ecológicas: 0. pixels não classificados; 1. Floresta de Brejo; 2. Área queimada; 3. Área sem indícios de perturbação recente; 4. Área com indícios de perturbação recente; 5. Faixa com efeito de borda; 6. Maciço de Diatenopteryx sorbifolia Radlk..

Tabela 11 - Índice de exatidão global da imagem resultante da classificação analógica de fotografia aérea em formato digital usando a escala 1:25.000.

\begin{tabular}{|l|l|}
\hline \multicolumn{2}{|c|}{ Exatidão global: 0.4057 - Desempenho médio: $59,43 \%$} \\
\hline $90 \%$ Confidence Interval & $+/-0.0060(0.39970 .4116)$ \\
\hline $95 \%$ Confidence Interval & $+/-0.0071(0.39850 .4128)$ \\
\hline $99 \%$ Confidence Interval & $+/-0.0094(0.39630 .4150)$ \\
\hline
\end{tabular}

Tabela 12 - Índice Kappa global e individual entre os dados da classificação analógica de fotografias aéreas em estereoscópio usando a escala 1:5.000, considerados como referência terrestre e da classificação analógica de fotografia aérea em formato digital usando a escala 1:25.000.

\begin{tabular}{|l|l|l|l|}
\hline \multicolumn{2}{|c|}{ Imagem classificada } & \multicolumn{2}{c|}{ Imagem de referência } \\
\hline \multicolumn{1}{|c|}{ Categoria } & KIA & \multicolumn{1}{c|}{ Categoria } & KIA \\
\hline Não classificado & 0.0000 & Floresta de Brejo & 0.7914 \\
\hline Floresta de Brejo & 0.7785 & Area queimada & 0.8237 \\
\hline Area queimada & 0.6548 & Area sem indícios de perturbação recente & 0.2521 \\
\hline Ȧrea sem indícios de perturbação recente & 0.1943 & Área com indícios de perturbação recente & 0.2053 \\
\hline Area com indícios de perturbação recente & 0.2725 & Faixa com efeito de borda & 0.3332 \\
\hline Faixa com efeito de borda & 0.6472 & Maciço de Diatenoptervx sorbifolia Radlk. & 0.7134 \\
\hline Maciço de Diatenoptervx sorbifolia Radlk. & 0.4828 & \\
\hline \multicolumn{2}{|c|}{ Indice de concordância Kappa global: 0.3331 } \\
\hline
\end{tabular}


Tabela 13 - Matriz de erro entre os dados da classificação analógica de fotografias aéreas em estereoscópio usando a escala 1:5.000, considerados como referência terrestre e da classificação analógica de fotografia aérea em estereoscópio usando a escala 1:25.000.

\begin{tabular}{|c|c|c|c|c|c|c|c|c|}
\hline \multirow{2}{*}{$\begin{array}{c}\text { Classes } \\
\text { mapeadas }\end{array}$} & \multicolumn{8}{|c|}{ Classes consideradas como a verdade terrestre } \\
\hline & 1 & 2 & 3 & 4 & 5 & 6 & Total & Erro C \\
\hline 0 & 45 & 33 & 58 & 145 & 5 & 0 & 286 & 1.0000 \\
\hline 1 & 762 & 0 & 17 & 59 & 0 & 26 & 864 & 0.1181 \\
\hline 2 & 1 & 771 & 0 & 393 & 0 & 0 & 1165 & 0.3382 \\
\hline 3 & 253 & 0 & 4513 & 10061 & 551 & 47 & 15425 & 0.7074 \\
\hline 5 & 26 & 0 & 14 & 44 & 181 & 0 & 265 & 0.3170 \\
\hline 6 & 0 & 0 & 35 & 45 & 0 & 140 & 220 & 0.3636 \\
\hline Total & 1087 & 804 & 4637 & 10747 & 737 & 213 & 18225 & \\
\hline Erro O & 0.2990 & 0.0410 & 0.0267 & 1.0000 & 0.7544 & 0.3427 & & 0.6506 \\
\hline
\end{tabular}

Erro O: erro de omissão (expresso em proporção); Erro C: erro de comissão (expresso em proporção); Classes de unidades ecológicas: 0. pixels não classificados; 1. Floresta de Brejo; 2. Área queimada; 3. Área sem indícios de perturbação recente; 4. Área com indícios de perturbação recente; 5. Faixa com efeito de borda; 6. Maciço de Diatenopteryx sorbifolia Radlk..

Tabela 14 - Índice de exatidão global da imagem resultante da classificação analógica de fotografia aérea em estereoscópio usando a escala 1:25.000.

\begin{tabular}{|c|c|}
\hline \multicolumn{2}{|c|}{ Exatidão global: 0.6506 - Desempenho médio: $34,94 \%$} \\
\hline $90 \%$ Confidence Interval & $+/-0.0058(0.64480 .6565)$ \\
\hline 95\% Confidence Interval & $+/-0.0069(0.64370 .6576)$ \\
\hline $99 \%$ Confidence Interval & $+/-0.0091(0.64150 .6598)$ \\
\hline
\end{tabular}

Tabela 15 - Índice Kappa global e individual entre os dados da classificação analógica de fotografias aéreas em estereoscópio usando a escala 1:5.000, considerados como referência terrestre e da classificação analógica de fotografia aérea em estereoscópio usando a escala $1: 25.000$.

\begin{tabular}{|c|c|c|c|}
\hline \multicolumn{2}{|c|}{ Imagem classificada } & \multicolumn{2}{c|}{ Imagem de referência } \\
\hline Categoria & KIA & Categoria & KIA \\
\hline Não classificado & 0.0000 & Floresta de Brejo & 0.6861 \\
\hline Floresta de Brejo & 0.8745 & Area queimada & 0.9562 \\
\hline Ȧrea queimada & 0.6462 & Área sem indícios de perturbação recente & 0.8259 \\
\hline Area sem indícios de perturbação recente & 0.0512 & Area com indícios de perturbação recente & 0.0000 \\
\hline Faixa com efeito de borda & 0.6697 & Faixa com efeito de borda & 0.2345 \\
\hline Maciço de Diatenoptervx sorbifolia Radlk. & 0.6321 & Maciço de Diatenoptervx sorbifolia Radlk. & 0.6531 \\
\hline \multicolumn{2}{|c}{ Indice de concordância Kappa global: 0.1640 } \\
\hline
\end{tabular}


Tabela 16 - Matriz de erro entre os dados da classificação analógica de fotografias aéreas em estereoscópio usando a escala 1:5.000, considerados como referência terrestre e da classificação não supervisionada usando imagem SPOT XS.

\begin{tabular}{|c|c|c|c|c|c|c|c|c|}
\hline \multirow{2}{*}{$\begin{array}{c}\text { Classes } \\
\text { mapeadas }\end{array}$} & \multicolumn{8}{|c|}{ Classes consideradas como a verdade terrestre } \\
\hline & 1 & 2 & 3 & 4 & 5 & 6 & Total & Erro C \\
\hline 0 & 160 & 89 & 89 & 221 & 13 & 0 & 572 & 1.0000 \\
\hline 1 & 126 & 0 & 53 & 72 & 0 & 5 & 256 & 0.5078 \\
\hline 2 & 0 & 618 & 0 & 296 & 0 & 0 & 914 & 0.3239 \\
\hline 3 & 402 & 4 & 2414 & 5434 & 125 & 20 & 8580 & 0.7186 \\
\hline 4 & 362 & 93 & 1650 & 3805 & 375 & 7 & 6292 & 0.3953 \\
\hline 5 & 37 & 0 & 431 & 919 & 224 & 0 & 1611 & 0.8610 \\
\hline Total & 1087 & 804 & 4637 & 10747 & 737 & 213 & 18225 & \\
\hline Erro O & 0.8841 & 0.2313 & 0.4794 & 0.6459 & 0.6961 & 1.0000 & & 0.6057 \\
\hline
\end{tabular}

Erro O: erro de omissão (expresso em proporção); Erro C: erro de comissão (expresso em proporção); Classes de unidades ecológicas: 0. pixels não classificados; 1. Floresta de Brejo; 2. Área queimada; 3. Área sem indícios de perturbação recente; 4. Área com indícios de perturbação recente; 5. Faixa com efeito de borda; 6. Maciço de Diatenopteryx sorbifolia Radlk.

Tabela 17 - Índice de exatidão global da imagem resultante da classificação não supervisionada usando imagem SPOT XS

\begin{tabular}{|c|c|}
\hline \multicolumn{2}{|c|}{ Exatidão global: 0.6057 - Desempenho médio: $39,43 \%$} \\
\hline $90 \%$ Confidence Interval & $+/-0.0060(0.59970 .6116)$ \\
\hline $95 \%$ Confidence Interval & $+/-0.0071(0.59860 .6127)$ \\
\hline $99 \%$ Confidence Interval & $+/-0.0093(0.59630 .6150)$ \\
\hline
\end{tabular}

Tabela 18 - Índice Kappa global e individual entre os dados da classificação analógica de fotografias aéreas em estereoscópio usando a escala 1:5.000, considerados como referência terrestre e da classificação não supervisionada usando da imagem SPOT XS.

\begin{tabular}{|l|l|l|l|}
\hline \hline \multicolumn{2}{|c|}{ Imagem classificada } & \multicolumn{2}{c|}{ Imagem de referência } \\
\hline \hline \multicolumn{1}{|c|}{ Categoria } & KIA & \multicolumn{1}{c|}{ Categoria } & KIA \\
\hline Não classificado & 0.0000 & Floresta de Brejo & 0.1033 \\
\hline Floresta de Brejo & 0.4600 & Area queimada & 0.7564 \\
\hline Area queimada & 0.6612 & Area sem indícios de perturbação recente & 0.0941 \\
\hline Area sem indícios de perturbação recente & 0.0361 & Area com indícios de perturbação recente & 0.0135 \\
\hline Area com indícios de perturbação recente & 0.0367 & Faixa com efeito de borda & 0.2364 \\
\hline Faixa com efeito de borda & 0.1028 & Maciço de Diatenoptervx sorbifolia Radlk. & 0.0000 \\
\hline \multicolumn{2}{|r|}{ Indice de concordância Kappa global: 0.0961} \\
\hline \hline
\end{tabular}


Tabela 19 - Matriz de erro entre os dados da classificação analógica de fotografias aéreas em estereoscópio usando a escala 1:5.000, considerados como referência terrestre e da classificação não supervisionada usando imagem Landsat TM.

\begin{tabular}{|c|r|r|r|r|r|r|r|r|}
\hline \multirow{2}{*}{$\begin{array}{c}\text { Classes } \\
\text { mapeadas }\end{array}$} & \multicolumn{7}{|c|}{ Classes consideradas como a verdade terrestre } \\
\hline & 1 & 2 & 3 & 4 & 5 & 6 & Total & Erro C \\
\hline 0 & 259 & 142 & 125 & 347 & 37 & 0 & 910 & 1.0000 \\
\hline 1 & 8 & 0 & 22 & 30 & 0 & 0 & 60 & 0.8667 \\
\hline 2 & 13 & 353 & 0 & 155 & 0 & 0 & 521 & 0.3225 \\
\hline 3 & 156 & 1 & 2961 & 6245 & 174 & 169 & 9706 & 0.6949 \\
\hline 4 & 539 & 308 & 1426 & 3712 & 363 & 44 & 6392 & 0.4193 \\
\hline 5 & 112 & 0 & 103 & 258 & 163 & 0 & 636 & 0.7437 \\
\hline Total & 1087 & 804 & 4637 & 10747 & 737 & 213 & 18225 & \\
\hline Erro O & 0.9926 & 0.5609 & 0.3614 & 0.6546 & 0.7788 & 1.0000 & & 0.6051 \\
\hline
\end{tabular}

Erro O: erro de omissão (expresso em proporção); Erro C: erro de comissão (expresso em proporção); Classes de unidades ecológicas: 0. pixels não classificados; 1. Floresta de Brejo; 2. Área queimada; 3. Área sem indícios de perturbação recente; 4. Área com indícios de perturbação recente; 5. Faixa com efeito de borda; 6. Maciço de Diatenopteryx sorbifolia Radlk..

Tabela 20 - Índice de exatidão global da imagem resultante da classificação não supervisionada usando imagem Landsat TM.

\begin{tabular}{|c|c|}
\hline \multicolumn{2}{|c|}{ Exatidão global: 0.6051 - Desempenho médio: $39,49 \%$} \\
\hline $90 \%$ Confidence Interval & $+/-0.0060(0.59910 .6111)$ \\
\hline $95 \%$ Confidence Interval & $+/-0.0071(0.59800 .6122)$ \\
\hline $99 \%$ Confidence Interval & $+/-0.0093(0.59580 .6144)$ \\
\hline
\end{tabular}

Tabela 21 - Índice Kappa global e individual entre os dados da classificação analógica de fotografias aéreas em estereoscópio usando a escala 1:5.000, considerados como referência terrestre e da classificação não supervisionada usando imagem Landsat TM.

\begin{tabular}{|l|l|l|l|}
\hline \multicolumn{2}{|c|}{ Imagem classificada } & \multicolumn{1}{c|}{ Imagem de referência } \\
\hline \multicolumn{1}{|c|}{ Categoria } & KIA & \multicolumn{1}{c|}{ Categoria } & KIA \\
\hline Não classificado & 0.0000 & Floresta de Brejo & 0.0041 \\
\hline Floresta de Brejo & 0.0784 & Area queimada & 0.4225 \\
\hline Area queimada & 0.6627 & Area sem indícios de perturbação recente & 0.2268 \\
\hline Area sem indícios de perturbação recente & 0.0679 & Area com indícios de perturbação recente & 0.0082 \\
\hline Area com indícios de perturbação recente & 0.0218 & Faixa com efeito de borda & 0.1930 \\
\hline Faixa com efeito de borda & 0.2249 & Maciço de Diatenoptervx sorbifolia Radlk. & 0.0000 \\
\hline \multicolumn{3}{|r}{ Indice de concordância Kappa global: 0.0759 } \\
\hline \multicolumn{4}{|l}{} \\
\hline
\end{tabular}




\subsection{Comparação entre os métodos de classificação de imagens}

Com base nos resultados dos métodos de classificação das fotografias aéreas e imagens orbitais e da comparação das unidades ecológicas identificadas com a verdade terrestre (Kappa), foi possível discutir quais os métodos mais promissores para estudo de vegetação, de acordo com seus objetivos.

Embora o resultado do método de análise analógica de fotografia aérea usando estereoscopia em escala 1:5.000 tenha sido considerado o melhor para classificação das unidades ecológicas, a maioria das fotografias aéreas disponiveis para uso estão em escalas iguais ou menores que 1:25.000. Dessa forma, o uso da análise analógica de fotografia aérea em formato digital, apresenta-se atualmente como grande potencial para ser usado em trabalhos de fragmentos florestais como ferramenta metodológica na análise do mosaico vegetacional, através da identificação e delimitação de unidades ecológicas, dada a indisponibilidade de fotografias em escala 1:5.000.

Entretanto, a técnica de análise analógica com fotografia aérea em formato digital apresentou problemas em relação ao tamanho de arquivo gerado na transformação da imagem fotográfica para o formato digital. Esses arquivos chegaram a ter, para a área recortada da Reserva (252 ha) em escala 1:25.000, aproximadamente $10 \mathrm{MB}$, sendo esse valor duplicado ou triplicado dependendo do modo de exibição de cores, exigindo assim, o uso de microcomputadores potentes para sua utilização. Apesar disso, se considerarmos que a maioria dos fragmentos florestais remanescentes possuem valores bem menores de área e dada a grande disponibilidade de fotografias aéreas na escala 1:25.000, essa metodologia mostra-se muito promissora, para estudos dessa natureza.

A utilização de escalas maiores que 1:25.000 foi mais vantajosa nesse tipo de análise, entretanto, ainda não são disponíveis para a maior parte das áreas estudadas. Esses problemas deverão ser resolvidos no futuro, principalmente com o desenvolvimento da tecnologia, tornando mais eficiente e menos onerosa a utilização dos sensores remotos orbitais. 
Os melhores resultados das análises das imagens orbitais foram obtidos pelas classificações não supervisionadas. A impossibilidade de definição de áreas homogêneas nas imagens para selecionar as amostras de treinamento torna essa técnica mais vantajosa em relação a classificação supervisionada (Novo, 1989; Quintanilha, 1990; Vettorazzi, 1992). Em termos de número de unidades ecológicas identificadas as fotointerpretações superaram as classificações realizadas em imagens orbitais, com exceção das análises estereoscópicas feita em escalas menores que 1: 25.000, onde não houve a separação das unidades "áreas sem indícios de perturbação recente" e "áreas com indícios de perturbação recente".

Apesar do número menor de unidades ecológicas identificadas, as classificações das imagens orbitais, apresentaram bons resultados em termos de identificação do gradiente sucessional. Os resultados obtidos com imagens orbitais demonstram a possibilidade de muitos estudos sobre a dinâmica florestal, já demonstrado nos trabalhos de Moran et al. (1994), Brondizio et al. (1993), entre outros, podendo subsidiar a adoção de práticas de conservação e manejo do pouco que resta de remanescentes naturais. Esse fato, somado à periodicidade com que os registros em imagens orbitais são realizados, definem esse método como um poderoso instrumento de monitoramento ambiental.

As classificações texturais ou espectrais/texturais, apresentaram discrepâncias entre os seus resultados, principalmente no que se refere a distribuição das unidades ecológicas na Reserva. Na classificação textural da fotografia aérea, aparentemente a resolução espacial utilizada na escanerização da fotografia (300 dpi) foi demasiadamente grande, causando a classificação de "microregiões" que apenas confundem os resultados, sem acrescentar informações de interesse. Nesse método, o algorítmo classificou diferentes texturas dentro de uma mesma unidade ecológica ou até mesmo numa única copa de árvore, identificando várias subclasses ou subagrupamentos para uma mesma unidade ecológica. A utilização de classificação espectral/textural para determinação de duas classes em floresta natural por Chen (1996), também não contribuiu para melhoria da discriminação das classes estudadas. Dessa forma, não fica totalmente descartada a possibilidade de utilização desse método em estudos dessa natureza, mas a sua 
recomendação depende ainda de mais estudos que possibilitem definir e compreender as ferramentas metodológicas para sua utilização.

As análises texturais ou espectrais/texturais das imagens orbitais tiveram resultados também insatisfatórios, não reconhecendo as unidades ecológicas identificadas nos outros métodos. Portanto, esse método que foi intensamente testado, não pode ser recomendado para a identificação das unidades ecológicas estudadas em fragmentos florestais.

No entanto, com o avanço da tecnologia dos sensores orbitais e o desenvolvimento de classificadores texturais mais eficientes, esse método poderá substituir as classificações espectrais, tornando o resultado dessas análises mais precisos.

Outros fatores que também estarão contribuindo para a melhoria dos resultados dos processamentos usando imagens orbitais são o aumentando as resoluções espaciais e espectrais dos sensores, além da disponibilidade de novos classificadores. Os resultados deverão ser melhores que os obtidos através das fotointerpretações, ressaltado pela disponibilidade periódica dessas imagens. Em função disso, uma estratégia interessante é o uso combinado dessas classificações orbitais com a fotointerpretação, corrigindo distorções através da comparação dos resultados e até o uso isolado dessas imagens, quando essas regiões não dispuserem de fotografias aéreas.

Algumas unidades ecológicas como a "faixa com efeito de borda" na face nordeste da imagem, apesar de algumas variações entre os resultados nos diferentes métodos, foi bem representada em todas as classificações. Entretanto, as unidades "áreas sem indícios de perturbação recente" e "áreas com indícios de perturbação recente" foram as unidades mais confusas para a definição de seus limites, já que naturalmente são unidades muito fragmentadas e cujas diferenças são graduais no espaço e no tempo.

A dificuldade de classificação dessas duas unidades ecológicas nas imagens, praticamente desapareceu em campo, em função de particularidade fisionômicas em escala real, com exceção dos trechos ecotonais. Na Reserva, esses ecótonos geralmente apresentaram-se com caraterísticas fisionômicas e florísticas intermediárias entre as duas 
unidades ecológicas adjacentes e ainda em faixas que varıam de poucos metros até dezenas de metros.

A checagem de campo mostrou que as unidades "áreas sem indícios de perturbação recente" e "áreas com indícios de perturbação recente" apresentaram-se entremeadas, sendo que na porção central da Reserva predominaram as "áreas sem indícios de perturbação recente" e nas áreas mais periféricas, com exceção da extremidade sul da Reserva, predominaram as "áreas com indícios de perturbação recente". Vale a pena ressaltar que, além dessas duas unidades ecológicas, foi encontrado ainda uma grande quantidade de pequenas clareiras (Gandolfi, 1999), que tornaram mais complexa a delimitação dos fragmentos dessas unidades.

Em função dos trabalhos de campo, podemos afirmar que para as unidades ecológicas "áreas sem indícios de perturbação recente" e "áreas com indícios de perturbação recente", os resultados da classificação realizada na fotointerpretação em análise estereoscópica na escala 1:5.000, apresentou o melhor resultado quanto a verdade terrestre, onde a fragmentação identificada foi semelhante ao que foi encontrado em campo.

Outra maneira de avaliar as vantagens e desvantagens de cada uma das metodologias usadas nas classificações foi através de parâmetros não só quantitativos mas também qualitativos dos processos envolvidos. A Tabela 22 apresenta esses parâmetros usados na comparação dos diferentes métodos de estudos.

Fatores como objetivo do trabalho, necessidade de monitoramento do mosaico, nível de detalhamento exigido, escala adotada, disponibilidade de recursos financeiros, etc., vão influenciar na definição do método mais adequado para estudos de vegetação. Desse modo, a Tabela 22 pode ajudar o analista a identificar o melhor método de acordo com as possibilidades do projeto e seus objetivos.

Em função disso, foi elaborada uma seqüência de opções metodológicas consideradas mais adequadas para os trabalhos de vegetação mais freqüentes (Tabela 24). Entretanto, ressaltamos que esta seqüência de opções depende da disponibilidade da fotografia ou imagem para a área de estudo. 


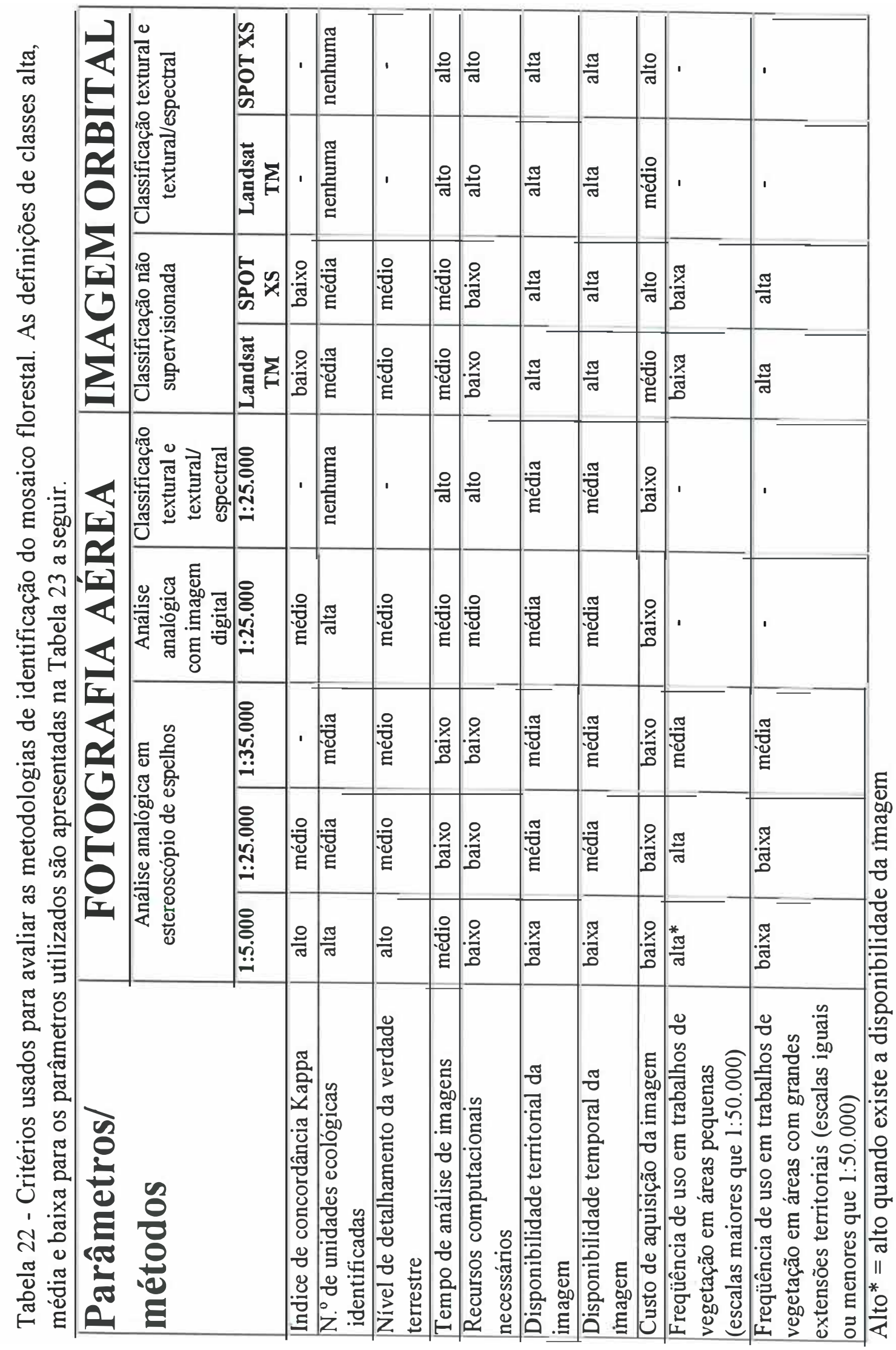




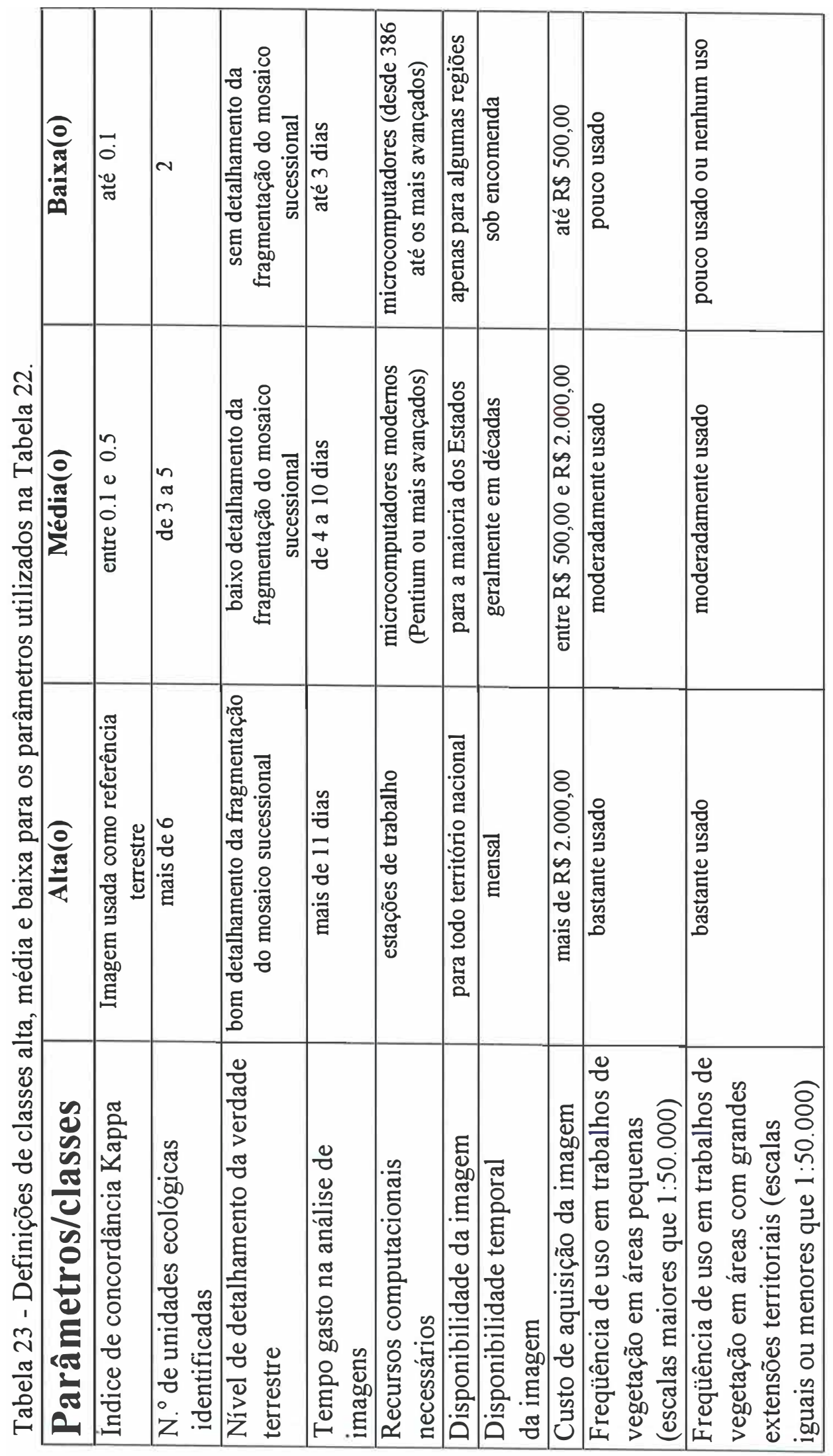




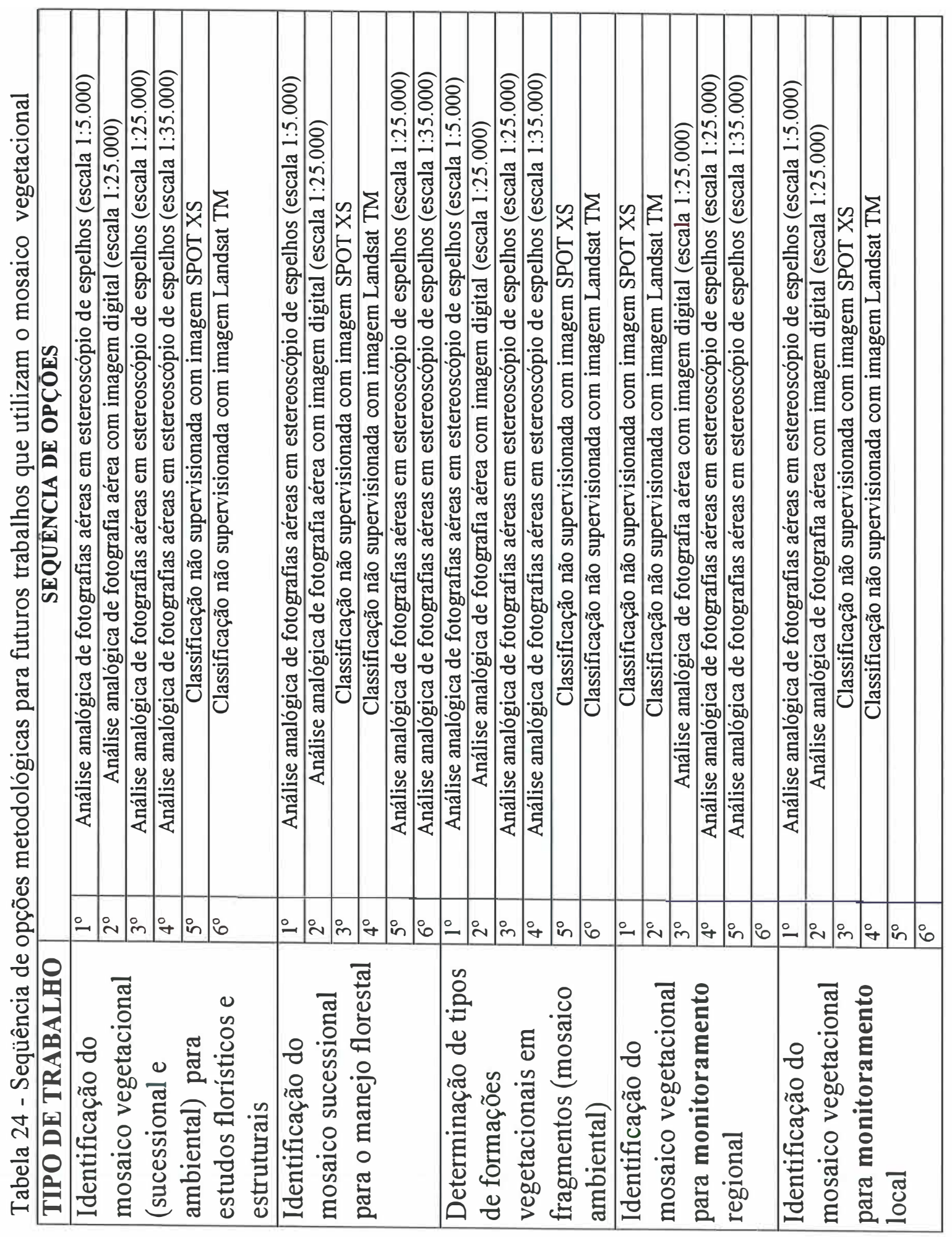


Dessa forma, se o objetivo do estudo for a identificação mais detalhada do mosaico vegetacional (sucessional e ambiental), deve ser usado os métodos que identificam um maior número de unidades ecológicas conjuntamente com um bom nível de detalhamento da verdade terrestre. Nestes casos, a análise analógica de fotografias aéreas em estereoscópio de espelhos (escala 1:5.000) e análise analógica de fotografia aérea com imagem digital (escala 1:25.000), se destacam dos outros métodos pela qualidade dos resultados apresentados. Por outro lado, nos casos em que se pretende monitorar o mosaico sucessional em uma região, seria mais viável a utilização de imagens orbitais.

\subsection{Análise temporal das fotografias aéreas}

Apesar dos mapas produzidos pelo método de estereoscopia usando escalas 1:25.000 e 1:35.000 não terem produzido a melhor definição das unidades ecológicas identificadas na Reserva, apresentaram grande potencial para monitoramento dessas unidades no tempo, permitindo fazer comparações e embasando as discussões sobre o histórico de perturbação da Reserva e da dinâmica florestal.

Com base nos resultados da fotointerpretação da Reserva nos anos 1972, 1978 e 1994, foi possível uma comparação das mudanças fisionômicas que ocorreram na vegetação florestal desde a primeira data analisada até a última, num intervalo de vinte e dois anos (Figura 5, 6 e 7).

Nessa análise temporal, a diferença mais evidente foi o avanço do efeito de borda que ocorreu na face nordeste da floresta nesse período, enquanto que em alguns trechos no lado oposto (sudoeste) esse efeito de borda apresentou-se com pouca expressão e extensão.

Provavelmente essa discrepância entre essas faces deve-se a direção preferencial dos ventos na região, que é nordeste, resultando em 2 características diferenciadas: 1) o vento permite a entrada dos impactos gerados no entorno (pesticidas da cultura de algodão, que foi plantado por muito tempo na área do entorno); 2) o vento mais intenso permite um aprofundamento do efeito de borda. 
Entretanto, nota-se que em fotografia aérea tirada no ano de 1962 (Matthes, 1991), ainda existia um grande trecho de floresta que dava continuidade aos limites sudoeste da área atual da Reserva de Santa Genebra, sendo separada apenas por uma estrada (Figura 18). $\mathrm{O}$ recente desflorestamento desse trecho de floresta na face sudoeste com aproximadamente 30 anos, pode ter contribuido para uma menor desestruturação dessa face da floresta, que teve sua exposição mais recente aos efeitos de borda, quando comparada ao restante da floresta.

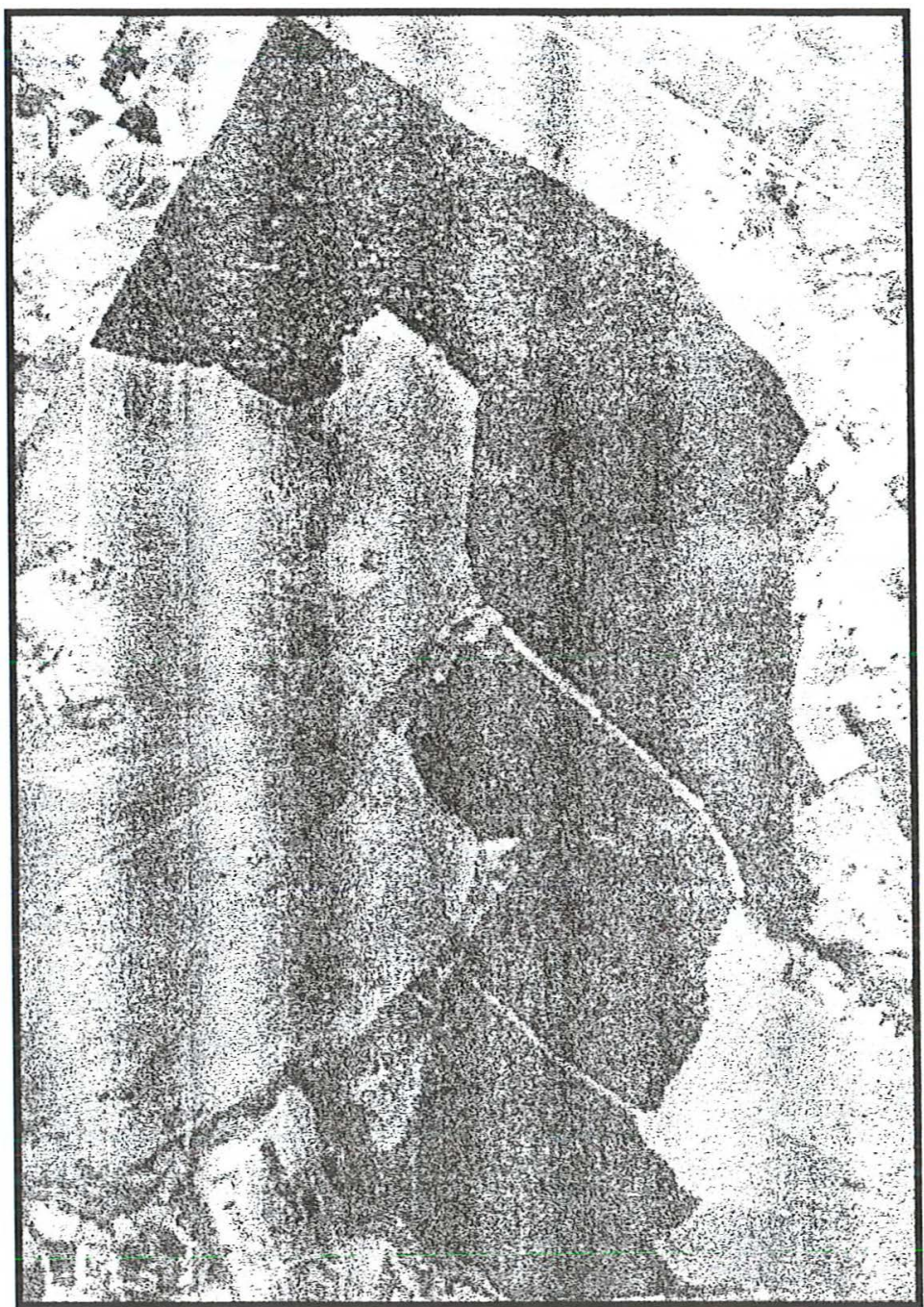

Figura 18 - Fotografia aérea da Reserva Municipal de Santa Genebra, Campinas, SP, do ano de 1962, limitando-se com outras áreas florestais na face sudoeste. 
Dessa forma, o tipo de atividade agricola do entorno tem grande influência sobre a composição do mosaico florestal, já que na face nordeste a atividade predominante era a cultura algodoeira, com uso de grande quantidade de pesticidas, principalmente herbicidas e inseticidas para o controle do bicudo, os quais foram levados para a floresta pelo vento e pelas descargas de água superficiais. A face sudoeste teve uso agrícola mais recente e posteriormente a cana-de-açúcar, com menor aplicação de pesticidas, sendo que para essa atividade o efeito conseqüente mais comum é o incêndio em trechos da borda do fragmento, já que a queimada compõe as práticas agrícolas dessa cultura.

$\mathrm{O}$ rápido avanço do efeito de borda nos fragmentos florestais, já relatado por vários autores, aponta para necessidade de uma estratégia de intervenção em que esse processo seja contido e mesmo revertido (Jorge, 1995)

Nas fotografias aéreas de 1972, alguns trechos da Reserva apresentaram-se bastante perturbados, onde aparentemente deve ter tido uma grande exploração seletiva de madeira e até mesmo corte raso em alguns locais. Nas análises dessas fotografias esses trechos foram diferenciados por apresentar um dossel homogêneo com copas estreitas, típicas de ecounidades em desenvolvimento, ao invés de um dossel heterogêneo em estágio mais avançado de sucessão, representada em outros trechos da floresta.

Uma dessas áreas identificadas como “áreas de extração seletiva”, situada na parte oeste, coincidiu exatamente onde a floresta pegou fogo no ano de 1981, alastrando-se facilmente devido ao alto grau de perturbação que esse trecho de floresta já se encontrava. Dessa forma, a unidade denominada "área queimada" não foi apresentada nas análises das fotografias de 1972 e 1978, mas apenas na classificação das fotografias de 1994 e nas imagens orbitais.

A evolução sucessional de um trecho dessas áreas altamente perturbadas e denominadas de "áreas de extração seletiva" pode ser percebida na comparação de um desses trechos situado na parte sudoeste da Reserva (Figura 19). Esse trecho aparentemente apresentou sinais de reestruturação da floresta no período de 1978 (Fotografia A) a 1994 (Fotografia B), que pode ser percebido pelo alargamento de copas arbóreas. 
Nesta mesma Figura 19, pode-se identificar nas duas fotografias, algumas copas pertencentes ao mesmo indivíduo arbóreo do dossel, possibilitando o mapeamento e acompanhamento dos mesmos no tempo. Esse mapeamento pode definir a estabilidade de trechos do dossel no tempo, auxiliando os trabalhos sobre a dinâmica florestal.

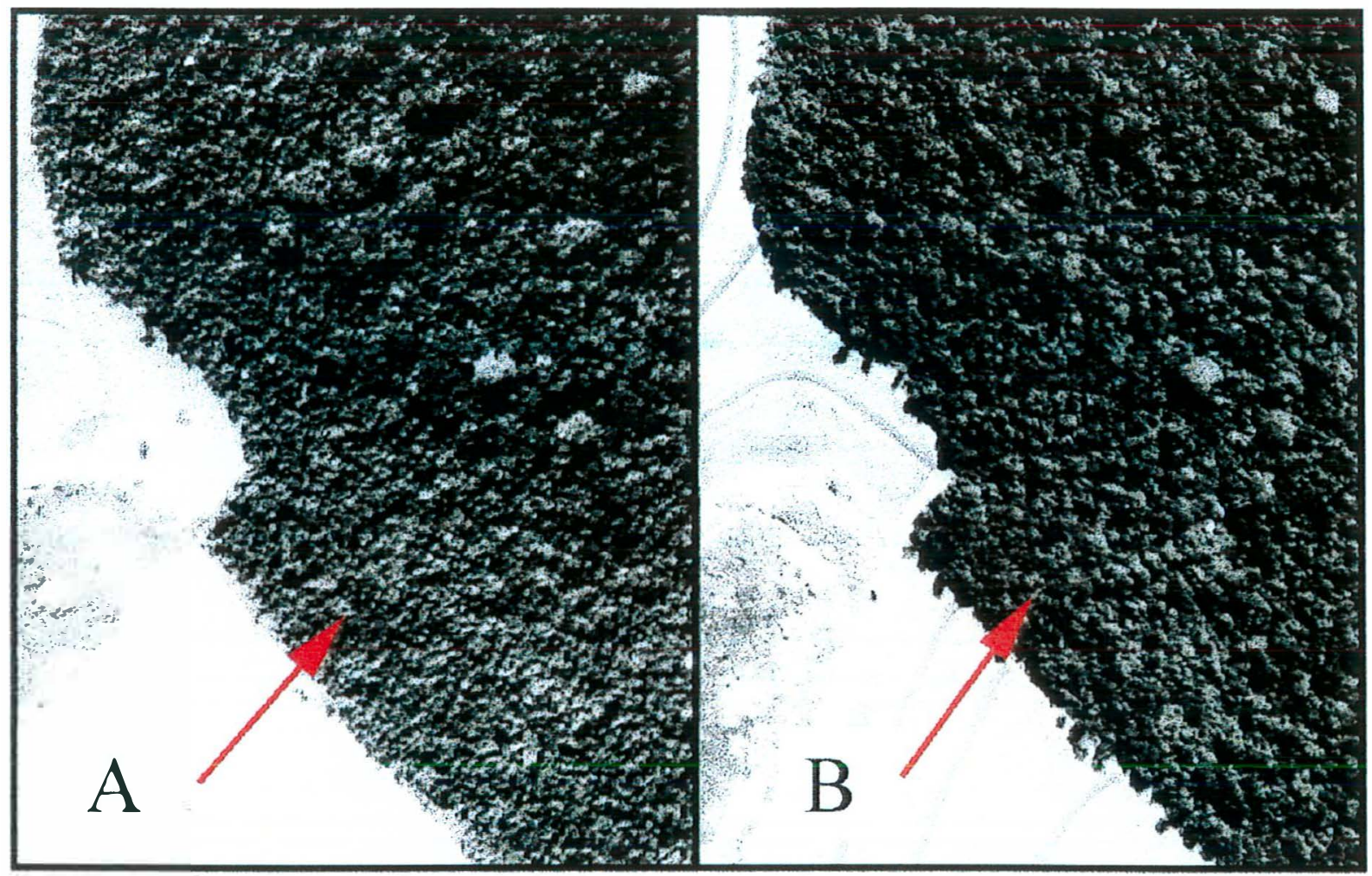

Figura 19 - Fotografias aéreas de junho de 1978 (A) e de junho de 1994 (B) da Reserva Municipal de Santa Genebra, Campinas, SP, mostrando reestruturação físionômica do trecho onde houve extração seletiva de madeira.

A floresta paludosa também sofreu perturbação antrópica durante o período estudado. Isso ocorreu devido ao assoreamento dos leito dos córregos, ocasionado pela mudança do regime hídrico, através da construção da estrada do entorno da Reserva, que proporcionou uma alteração na drenagem, resultando num maior tempo de permanência da água no solo. Além disso, houve $\odot$ carreamento de sedimentos originados nas atividades agrícolas. A conseqüência foi a mortalidade das árvores passando de uma floresta paludosa 
para um campo úmido (ou várzea) inclusive dominado por espécies herbáceas, nativas e exóticas (Taboa e Braquiaria humidicola).

Nessa análise temporal, a unidade "maciço de Maria-preta" manteve-se praticamente com as mesmas dimensões e localização em mapa, que já era esperado devido ao crescimento lento da espécie Diatenopteryx sorbifolia Radlk., caracterizando uma área em estado avançado de sucessão. A dominância dessa espécie nessa unidade ecológica sugere uma relação de alelopatia com outras espécies da floresta, da mesma forma que ocorre com a espécie Pachystroma longifolium (Canxim) em alguns trechos da Reserva.

\subsection{Caracterização e comparação florística, fisionômica e estrutural das unidades ecológicas identificadas}

4.7.1. Caracterização florística da Reserva Municipal de Santa Genebra, considerando todas as unidades ecológicas estudadas

Nesse item são apresentados os dados florísticos da Reserva Municipal de Santa Genebra, considerando todas as unidades ecológicas identificadas no zoneamento. O Anexo A apresenta todas as espécies amostradas por ordem de família, classificação sucessional, nome vulgar e em quais unidades ecológicas elas ocorreram, onde " 0 " significa ausência e "1" significa presença nas unidades ecológicas. A determinação das classes sucessionais foi obtida através dos trabalhos de Bernacci, 1992; Rodrigues et al., 1992; Gandolfi et al., 1995 e Gandolfi, 1999. Para algumas espécies a classificação sucessional ainda é desconhecida, por isso foram definidas como sem classificação.

Na listagem total da flora da Reserva (anexo A) foram encontradas 346 espécies pertencentes a 73 famílias. Entretanto, grande parte do material coletado nos levantamentos fitossociológicos encontrava-se infértil, e em alguns casos não foi possível a completa identificação. Mesmo assim, como a maior parte desse material botânico amostrado foi separado em morfoespécies através de comparação (mesmo sem completa identificação, mas 
a maioria já identificado em nível de gêneros), eles foram usados nas análises qualitativas e quantitativas.

As 6 famílias de maior riqueza florística para a Reserva como um todo, considerando todas as unidades ecológicas, foram Myrtaceae, com 36 espécies, seguida de Rubiaceae com 24, Fabaceae com 22, Rutaceae com 18, Euphorbiaceae com 16 cada e Bignoniaceae com 15 espécies.

Se considerarmos as famílias Fabaceae, Mimosaceae e Caesalpiniaceae de Cronquist (1981) como uma única família (Leguminosae), com base no sistema de Engler (citado por Joly, 1977), esta apresentou a segunda maior riqueza, com 35 espécies. Esses dados se aproximaram da expectativa esperada para os trabalhos realizados em Florestas Estacionais Semideciduais do Estado de São Paulo, onde a família das Leguminosas é a de maior riqueza florística (Leitão Filho, 1987; Matthes et al., 1988; Baitelo et al., 1988; Rodrigues et al., 1989; Meira Neto et al., 1989; Martins, 1993 e outros).

A Tabela 25 apresenta de forma resumida alguns parâmetros florísticos e estruturais de todas as unidades ecológicas estudadas.

Embora esse trabalho contribua com o acúmulo de conhecimento sobre a flora dessa Reserva, sabemos que o esforço amostral foi insuficiente para o conhecimento de todas as espécies vegetais ocorrentes nessa unidade de conservação. Entretanto, o número de espécies já identificadas até o momento reforça a importância desse remanescente florestal, visando a conservação "in situ" da diversidade vegetal regional.

Essa riqueza de espécies da Reserva Municipal de Santa Genebra, se deve em parte, ao tamanho do fragmento (252 ha) e também pelo mosaico ambiental (floresta paludosa e floresta estacional semidecidual) e sucessional (área queimada, clareiras, efeito de borda etc.). 


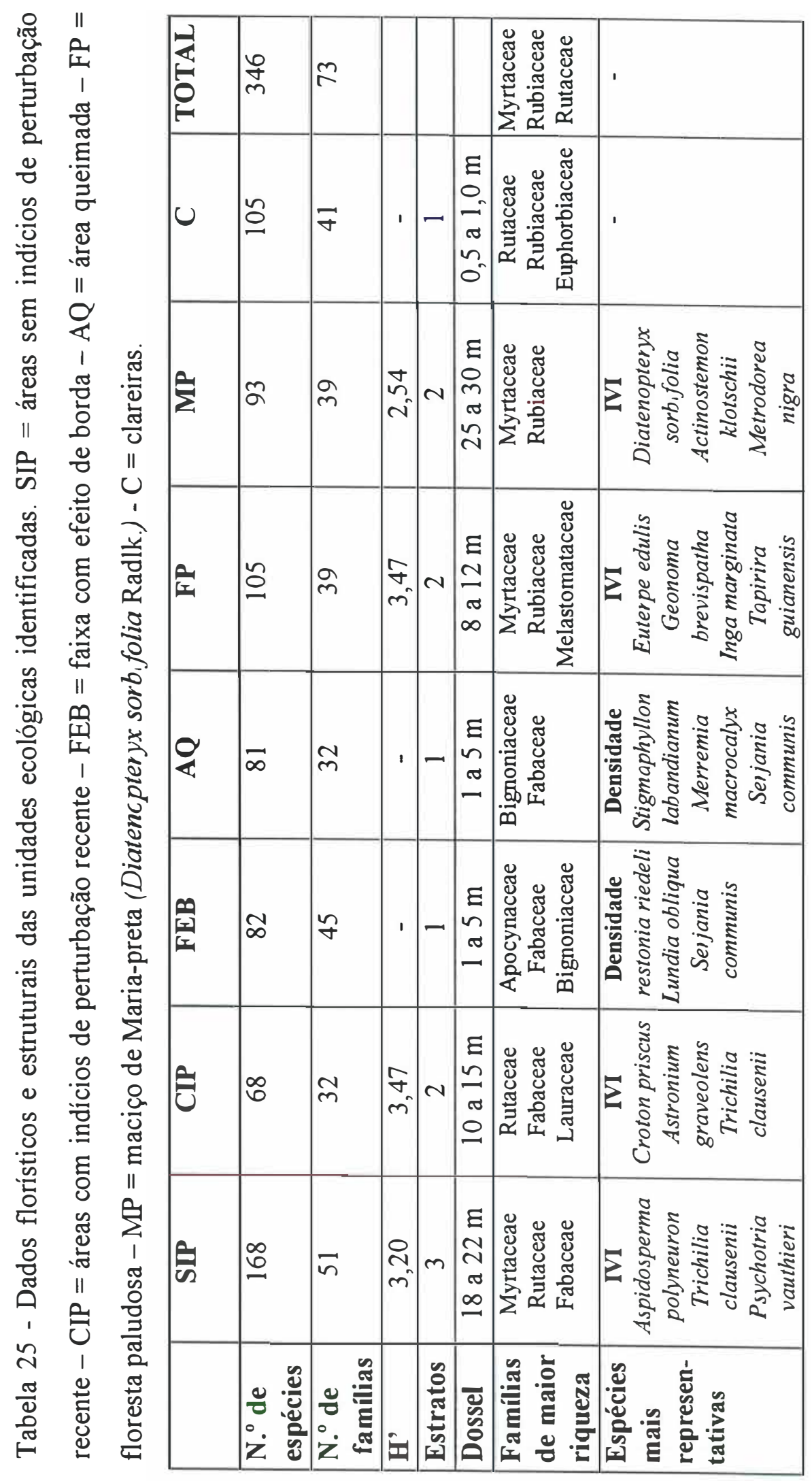


4.7.2. Caracterização florística, fisionômica e estrutural de cada unidade ecológica

\subsubsection{1. Áreas sem indicios de perturbação recente}

Essas áreas apresentaram dossel elevado variando de 18 a $22 \mathrm{~m}$ de altura representadas por algumas espécies típicas desse estrato como Pachystroma longifolium (Canxim), Copaifera langsdorffii (Copaíba), Astronium graveolens (Guaritá), Diatenopteryx sorbifolia Radlk. (Maria-preta), Esenbeckia leiocarpa (Guarantã), Endlicheria paniculata (Canela-do-brejo) e Cabralea canjerana (Canjerana). Os indivíduos emergentes pertenciam as espécies Aspidosperma polyneuron (Peroba-rosa), Cariniana legalis (Jequitibá-rosa), Cariniana estrelensis (Jequitibá-branco), entre outros, chegando a atingir cerca de $35 \mathrm{~m}$ de altura. Os indivíduos que constituem os estratos superiores da floresta apresentavam copas grandes e largas, com nítida deciduidade sazonal de parte das espécies e indivíduos, típico desse tipo de formação florestal.

Essa unidade estudada também apresentou mais dois estratos bem definidos. Um sub-bosque com cerca de 1,5 a 2,5 m de altura, constituídos por indivíduos jovens dos estratos superiores e espécies comuns desse estrato como, Actinostemon klotschii, Calyptranthes concina, Trichilia catigua (Catiguá), Piper gaudichaudiamum, entre outros. O outro estrato identificado foi o sub-dossel com cerca de 6 a $8 \mathrm{~m}$ de altura, apresentando, além dos indivíduos jovens do estrato superior, espécies como Esenbeckia febrifuga, Myrcia rostrata, Psychotria carthaginensis, Trichilia catigua, Trichilia clausenii, etc. Também foram freqüentemente encontradas nesse ambiente, pequenas clareiras geralmente com menos de $100 \mathrm{~m}^{2}$ não detectadas na fotointerpretação em função da escala das aerofotografias usadas.

Nessa unidade ecológica foram encontradas nos trabalhos de Rodrigues et al. (1998) e Gandolfi (1999), 51 famílias, 110 gêneros e 170 espécies. Do total de espécies

amostradas no levantamento fitossociológico do trabalho de Rodrigues et al. (1998), $41,6 \%$ foram de espécies secundárias tardias, $36,7 \%$ foram de secundárias iniciais, $12,9 \%$ 
de espécies pioneiras e $8,8 \%$ de espécies sem caracterização sucessional. O predomínio de espécies finais da sucessão, sinalizam para um bom estado de preservação do trecho de mata estudado, pelo menos no momento do estudo.

$\mathrm{O}$ indice de diversidade de Shannon $\left(\mathrm{H}^{\prime}\right)$ obtido para esse trecho de floresta estacional semidecidual foi de 3.20 nats/individuos. Esse valor é próximo daqueles obtidos em outros trabalhos de trechos contínuos dessa mesma unidade fitogeográfica, com diâmetro mínimo semelhante (Cavassan et al., 1984; Matthes et al., 1988; Gabriel, 1990; Bernacci, 1992) e ligeiramente inferior àqueles obtidos para gradientes altitudinais ou vegetacionais (Strufaldi-De-Vuono, 1985; Rodrigues et al., 1989; Silva, 1989; Grombone et al., 1990), para valores de diâmetro mínimo inferiores ao desse trabalho (Pagano et al., 1987; Nicolini, 1990) ou para áreas muito extensas dessa formação, com maior diversidade de ambientes e niveis menos significativos de extinção local (Schilittler, 1990). Dessa forma, a comparação de valores de diversidade deve considerar o método de amostragem e a heterogeneidade ambiental do trecho de floresta amostrado.

As famílias de maior riqueza florística somando-se as espécies encontradas nos trabalhos de Rodrigues et al. (1998) e Gandolfi (1999) foram Myrtaceae, com 17 espécies, seguida de Rutaceae com 14, Fabaceae com 13, Euphorbiaceae com 12, Rubiaceae e Lauraceae com 10 cada. Se considerarmos as famílias Fabaceae, Mimosaceae e Caesalpiniaceae de Cronquist (1981) como uma única família (Leguminosae), com base no sistema de Engler (citado por Joly, 1977), esta se apresentaria como a primeira de maior riqueza, com 19 espécies.

Esses dados concordam com os trabalhos apresentados em Florestas Estacionais Semideciduais do Estado de São Paulo, onde a família das Leguminosa foi a que geralmente apresentou a maior riqueza florística (Leitão Filho, 1987; Matthes et al., 1988; Baitelo et al., 1988; Rodrigues et al., 1989; Meira Neto et al., 1989; Martins, 1993 e outros). 


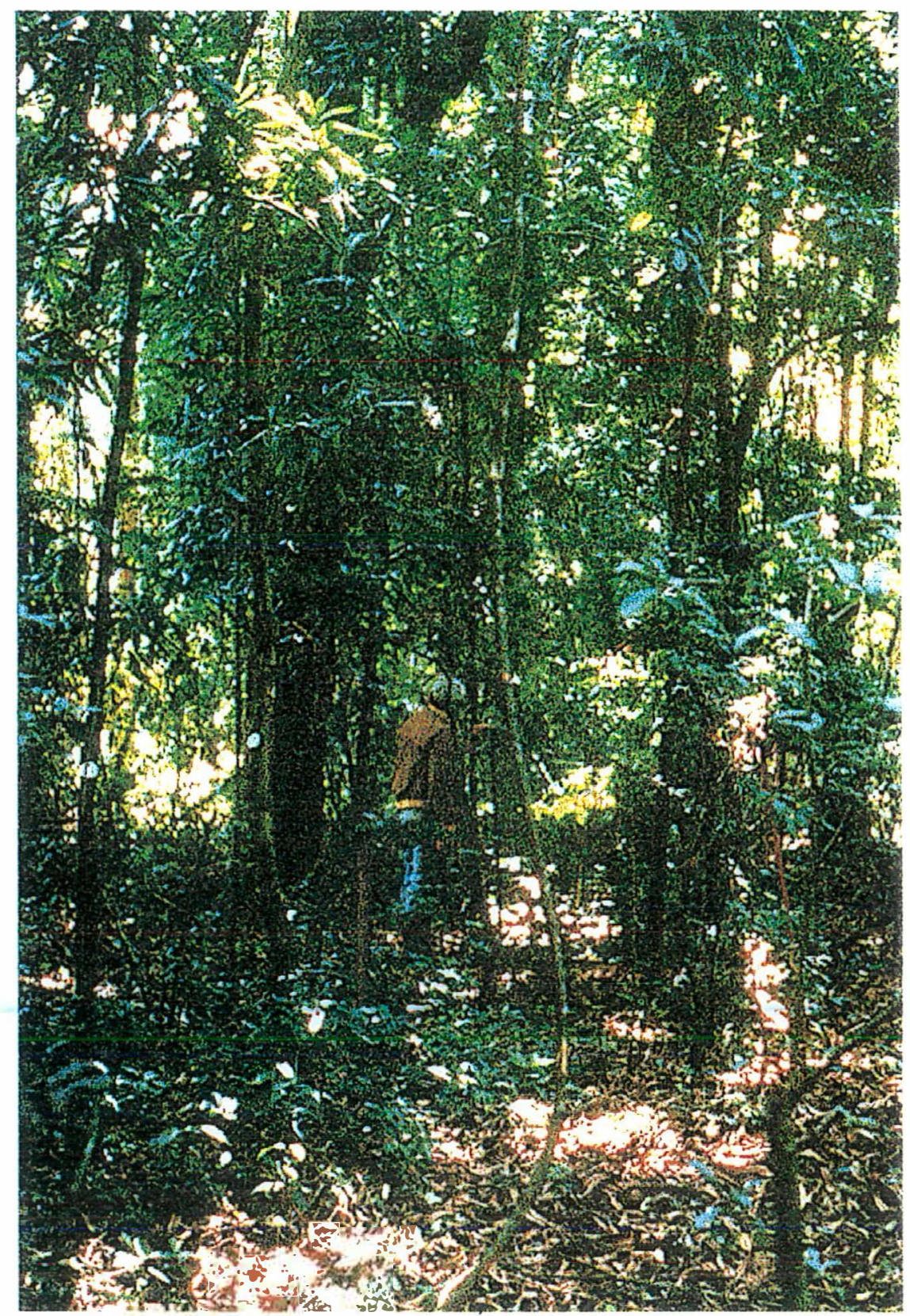

Figura 20 - Interior da unidade ecológica "Areas sem indícios de perturbação recente", Reserva Municipal de Santa Genebra, Campinas, SP.

No trabalho de Rodrigues et al. (1998), a espécie de maior valor de importância foi Aspidosperma polyneuron (Peroba-rosa) com 46,91, seguida de Trichilia clausenii com 36,83, Psychotria vauthieri com 28,52, Piptadenia gonoacantha (Pau-jacaré) com 20,13, Astronium graveolens (Guaritá) com 16,18 e Actinostemon klotschii com 14,98, que juntas somaram $53,95 \%$ do IVI total. 


\subsubsection{2. Áreas com indícios de perturbação recente}

Essa unidade ecológica se caracterizou por apresentar fisionomia florestal com um estágio avançado de degradação da unidade ecológica anteriormente descrita. Esse condição está relacionada com antigas retiradas seletivas de madeiras no interior da floresta, além de outros fatores de degradação geralmente relacionados com as atividades agrícolas do entorno, que dão origem a uma fisionomia e estrutura própria para essa unidade.

Essas áreas apresentavam o dossel com indivíduos arbóreos de porte variando de 10 a $15 \mathrm{~m}$ de altura, quase sempre constituído por espécies consideradas pioneiras, tais como: Croton floribundus (Capixingui), Croton priscus, Jacaratia spinosa (Jaracatiá) e Vernonia diffusa e espécies consideradas secundárias (tardias), tais como: Aspidosperma polyneuron (Peroba-rosa), Cabralea canjerana (Canjerana), Trichilia claussenii. Alguns indivíduos remanescentes chegaram a atingir cerca de $30 \mathrm{~m}$ de altura, geralmente apresentando-se em estado senescente e suas copas tomadas por lianas.

Essa unidade ecológica, além de ter apresentado um dossel irregular, possuía as copas das árvores com formas muito variadas e geralmente com dimensões menores que as áreas sem indícios de perturbação recente. O sub-dossel e sub-bosque eram pouco definidos e bem mais densos que na unidade "áreas sem indícios de perturbação recente".

Algumas espécies que constituíam os estratos superiores dessa unidade ecológica foram também encontradas na unidade "áreas sem indícios de perturbação recente", embora com densidade e organização comunitária bem distintas.

Essas unidades ecológicas apresentaram muitas clareiras em seu interior, sendo que a maior incidência de luz nos estratos inferiores dessa unidade aumentaram muito o número de espécies oportunistas ou de estágio inicial da sucessão, fazendo com que a unidade seja reocupada por muitos indivíduos de algumas espécies pertencentes as outras formas de vida vegetal que foram favorecidas pela perturbação antrópica, como lianas, touceiras de bambus (Merostachys riedeliana), arbustos escandentes, etc (Figura 21). Esses indivíduos oportunistas apresentavam-se geralmente com alta densidade, e que 
junto com a presença de indivíduos arbóreos caídos, dificultavam bastante o deslocamento nesses locais.

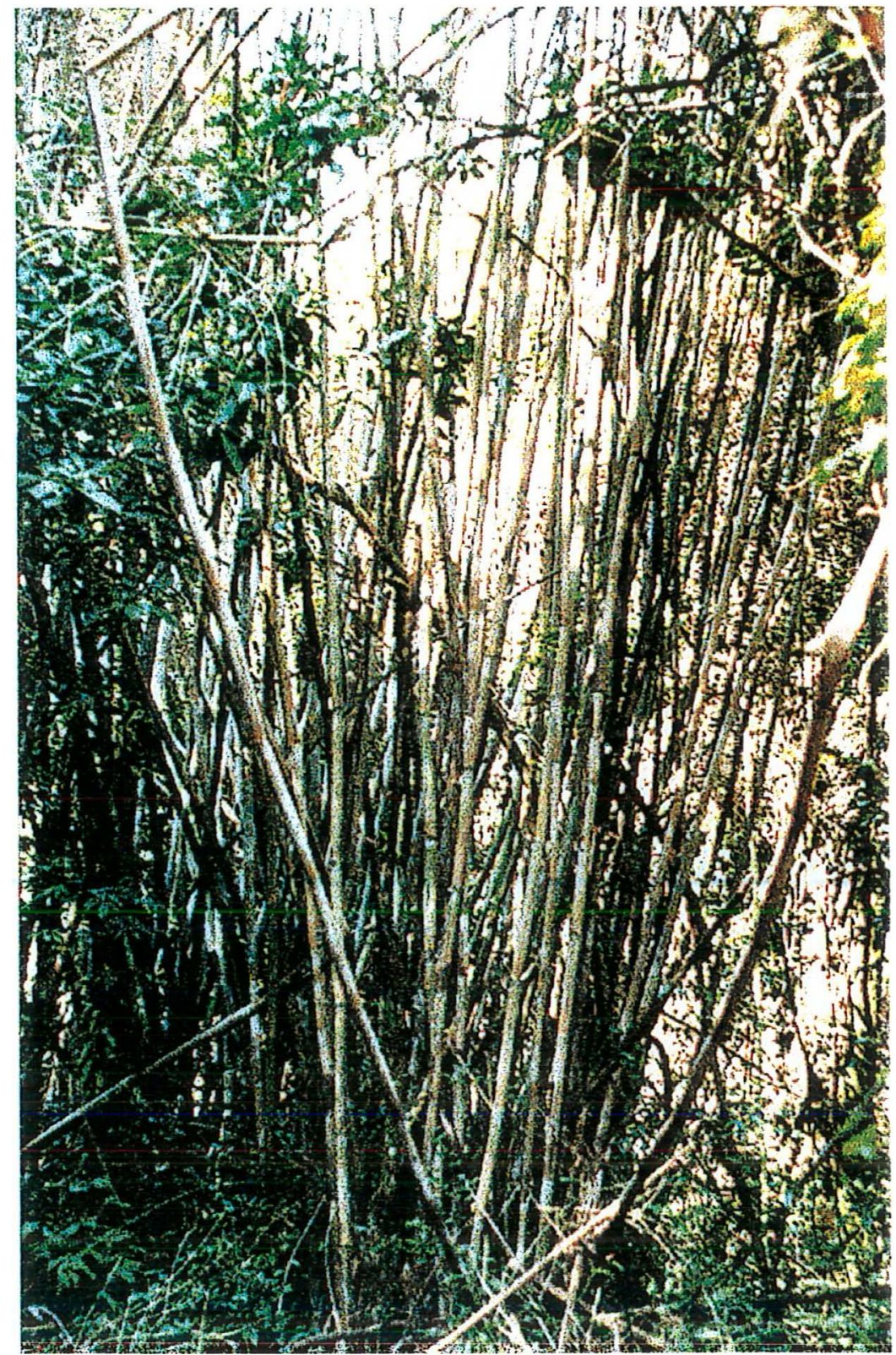

Figura 21 - Destaque de uma touceira de bambu (Merostachys riedeliana) na unidade ecológica "Faixa com indícios de perturbação recente", Reserva Municipal de Santa Genebra, Campinas, SP.

Nessa unidade ecológica foram encontradas 32 famílias e 68 espécies. Do total de indivíduos amostrados, $37,5 \%$ foram de espécies secundárias tardias, $31,8 \%$ foram de 
secundárias iniciais, $27,6 \%$ de espécies pioneiras e 3,1\% de espécies sem caracterização sucessional. O predomínio de espécies iniciais da sucessão, demonstrou um estado bastante perturbado do trecho de estudado.

As famílias de maior riqueza florística foram Rutaceae com 8 espécies, seguida de Fabaceae e Lauraceae com 5 cada, Mimosaceae e Euphorbiaceae com 4 cada e Myrtaceae, com 3 espécies.

Se considerarmos as famílias Fabaceae, Mimosaceae e Caesalpiniaceae de Cronquist (1981) como uma única família (Leguminosae), com base no sistema de Engler citado por Joly (1977), esta se apresentaria como a primeira maior riqueza, com 9 espécies. Esses dados continuam concordando com a expectativa esperada para os trabalhos de Floresta Estacional Semidecidual do Estado de São Paulo, mesmo em estágio mais avançado de degradação, onde a família das Leguminosa foi a de maior riqueza florística (Struffaldi-de-Vuono, 1985; Rossi, 1987; Catharino, 1989; KotcherkHenriques \& Joly, 1994).

$\mathrm{O}$ índice de diversidade de Shannon $\left(\mathrm{H}^{\prime}\right)$ obtido para esse trecho de floresta estacional semidecidual foi de 3,472 nats/indivíduos. Esse valor foi considerado normal e bem próximo dos valores encontrados para trabalhos de trechos contínuos, com diâmetro mínimo semelhante (Cavassan et al., 1984; Matthes et al., 1988; Gabriel, 1990; Bernacci, 1992) dessa mesma unidade fitogeográfica e certamente mais elevado que a unidade anterior. A constatação de que a diversidade aumenta nos locais mais perturbados de uma mesma unidade fitogeográfica, já foram citadas por vários autores.

As 5 espécies de maior IVI foram Croton priscus, seguida de Astronium graveolens (Guaritá), Trichilia clausenii, Croton floribundus (Capixingui) $e$ Aspidosperma polyneuron (Peroba-rosa), que juntas somaram 53,95\% do IVI total. 


\subsubsection{Faixa com efeito de borda}

O único estrato definido nesta unidade era constituído pela vegetação herbáceoarbustiva, quase sempre coberta por um emaranhado de lianas (Figura 22). Nessa unidade encontrou-se também freqüentemente touceiras de bambu (Merostachys riedeliana). Nos limites entre essa unidade ecológica e o acero que circunda a Reserva, existia uma faixa que variava geralmente de 3 a $8 \mathrm{~m}$ de largura, apresentando predominantemente Capim Colonião (Panicum maximum). A presença dessa espécie invasora pode ser observada na Figura 23.

Essas áreas apresentaram indivíduos isolados emergentes, chegando a atingir cerca de $25 \mathrm{~m}$ de altura, geralmente tomado por lianas, muitas vezes impedindo a visualização da copa desses indivíduos e a identificação da espécie. Entre esses indivíduos arbóreos remanescentes de maior porte foram encontradas espécies, tais como Aspidosperma polyneuron (Peroba-rosa), Zeyheria tuberculosa (Ipê-felpudo), Astronium graveolens (Guaritá) e Cariniana legalis (Jequitibá-rosa). Outros indivíduos arbóreos apresentavam-se com copa geralmente bem estreita pela queda de galhos, tomadas por lianas, constituindo-se nas chamadas colunas de cipós, como exemplo temos o Croton floribundus, Nectandra megapotanica (Canelinha), Holocalyx balanse (Alecrim-decampinas), Alchornea triplinervia (Tapiá), Syagrus romanzofiana (Jerivá), entre outras.

Algumas espécies arbóreas como Cecropia hololeuca (Embaúva), Aspidosperma cylindrocarpum (Peroba-poca), Aspidosperma polyneuron (Peroba-rosa), Trema micrantha (Crindiúva), Jacaratia spinosa (Jaracatiá), Cabralea canjerana (Canjerana), Ormosia arborea (Olho-de-cabra), Croton priscus, Centrolobium tomentosum (Araribá), Astronium graveolens (Guaritá), Schizolobium parayba (Guapuruvú) e ainda espécies invasoras como a Ricinus klotschii L. (mamona) se destacaram pelo fato de seus indivíduos não apresentarem as copas tomadas por lianas. 


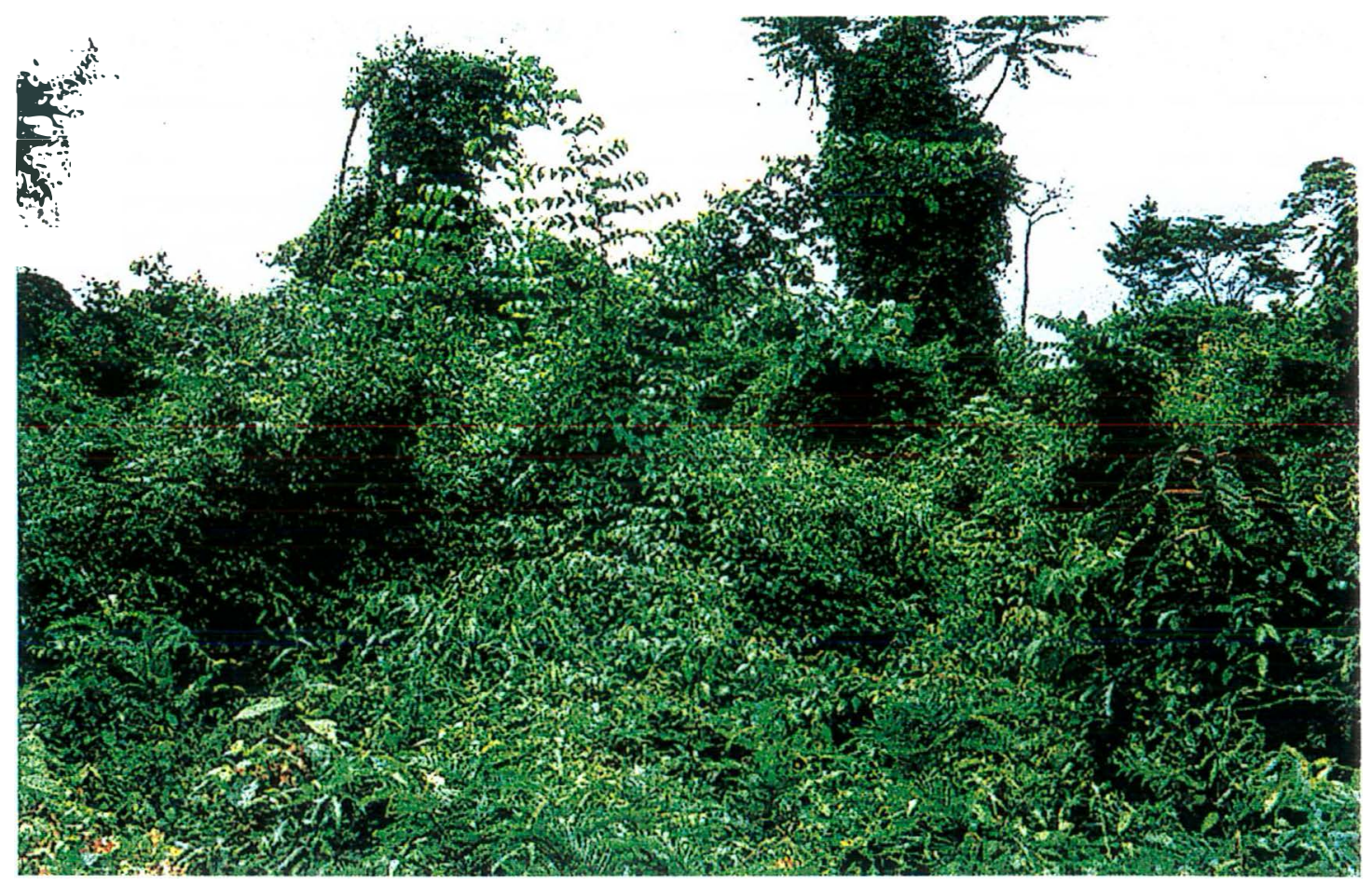

Figura 22 - Perfil de um trecho da unidade ecológica "Faixa com efeito de borda", Reserva Municipal da Santa Genebra, Campinas, SP.

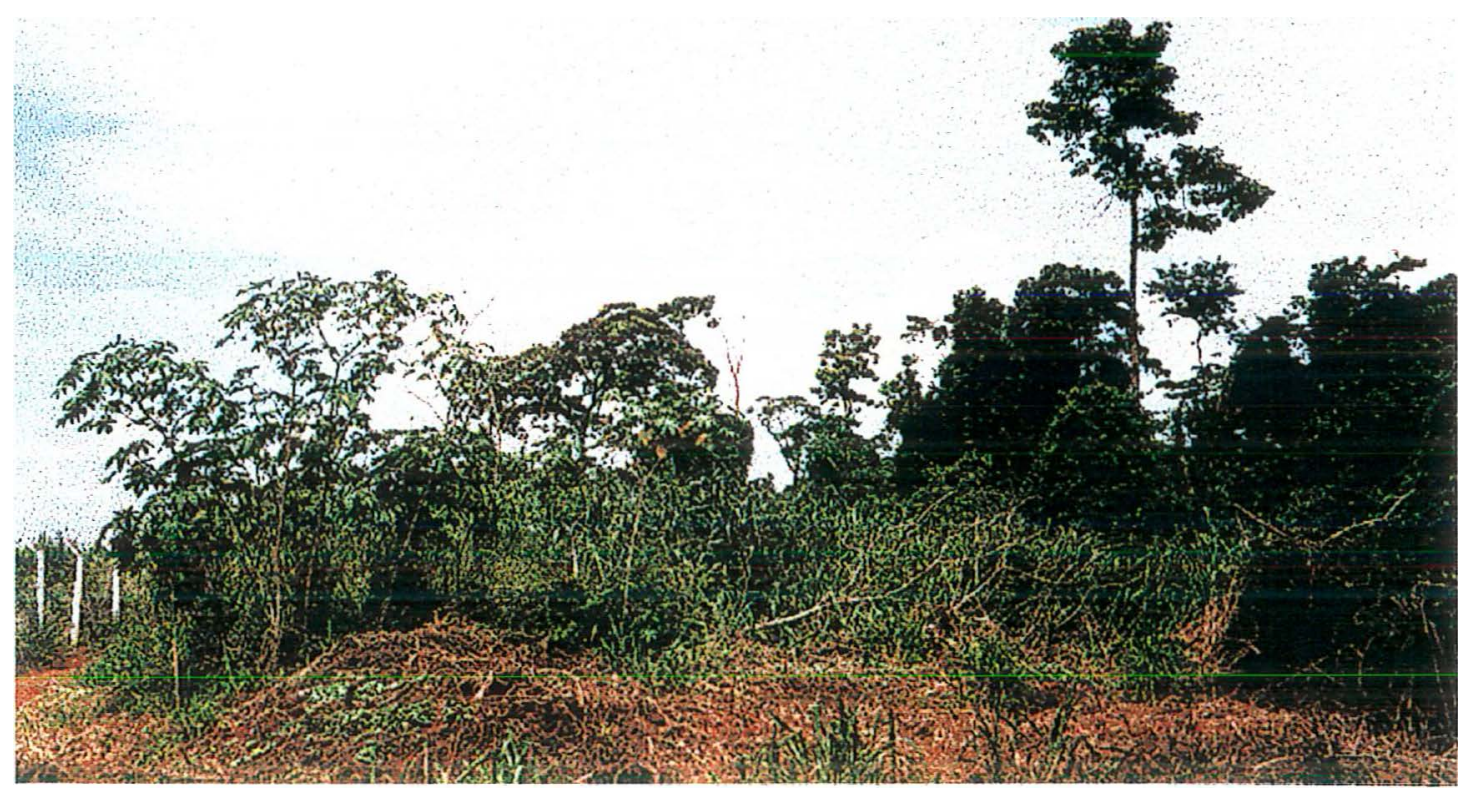

Figura 23 - Faixa com cerca de $8 \mathrm{~m}$ de largura predominando Capim Colonião (Panicum maximum), Reserva Municipal da Santa Genebra, Campinas, SP. 
As espécies de maior densidade foram as lianas: Prestonia riedeli, Lundia obliqua e Serjania communis.

Nessa unidade ecológica foram encontradas 45 famílias, 71 gêneros e 80 espécies. As famílias de maior riqueza florística foram Apocynaceae e Fabaceae, com 6 espécies cada, seguida de Bignoniaceae e Malpighiaceae com 4 cada, Sapindaceae e Solanaceae com 3 espécies cada. Essas famílias de maior riqueza se diferenciaram bastante daquelas apresentadas anteriormente para as unidades "áreas sem indícios de perturbação recente" e "áreas com indícios de perturbação recente". Isso ocorreu devido ao fato dessa unidade ter amostrado a maior parte dos indivíduos na forma de lianas que predominam nesses locais com espécies típicas de algumas famílias de maior riqueza florística (Bignoniaceae, Malpighiaceae, Apocynaceae, etc.). Isso também ocorreu para a unidade "área queimada".

\subsubsection{4. Área queimada}

$\mathrm{Na}$ área queimada o único estrato definido era constituído pela vegetação herbáceo-arbustiva (Figura 24), geralmente coberta por um emaranhado de lianas. Esta unidade ecológica apresentou fisionomia muito semelhante a "faixa de efeito de borda".

Nos limites entre essa unidade ecológica e o acero que circunda a Reserva, existia uma faixa que variava geralmente de 3 a $5 \mathrm{~m}$ de largura (Figura 25), apresentando predominantemente a espécie Brachiaria decumbens Stapt. (Braquiária) mais também apresentou trechos com Panicum maximum Jacq. (Capim-colonião).

Nessa área foram encontradas poucas touceiras com indivíduos jovens de Merostachys riedeliana entretanto, notou-se durante o levantamento, a presença de muitos bambus secos por baixo da vegetação herbácea, provavelmente dessa espécie. A morte dessas touceiras ocorreu após a floração dessa espécie no ano de 1994, sendo que esse ambiente foi então dominado por essa espécie em anos anteriores e posteriormente recoberto pelas lianas. 


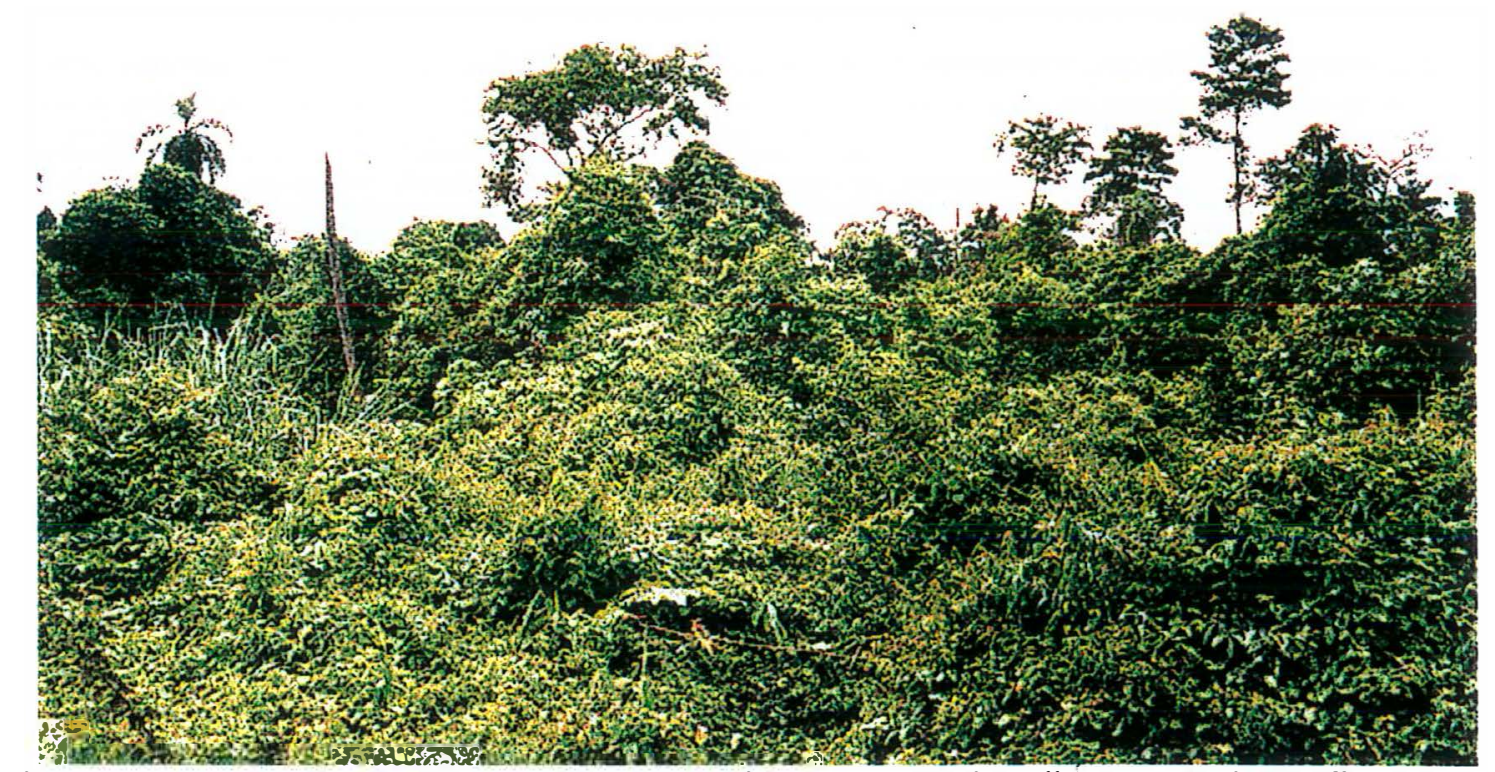

Figura 24 - Perfil de um trecho da unidade ecológica "Area queimada", Reserva Municipal de Santa Genebra, Campinas, SP.

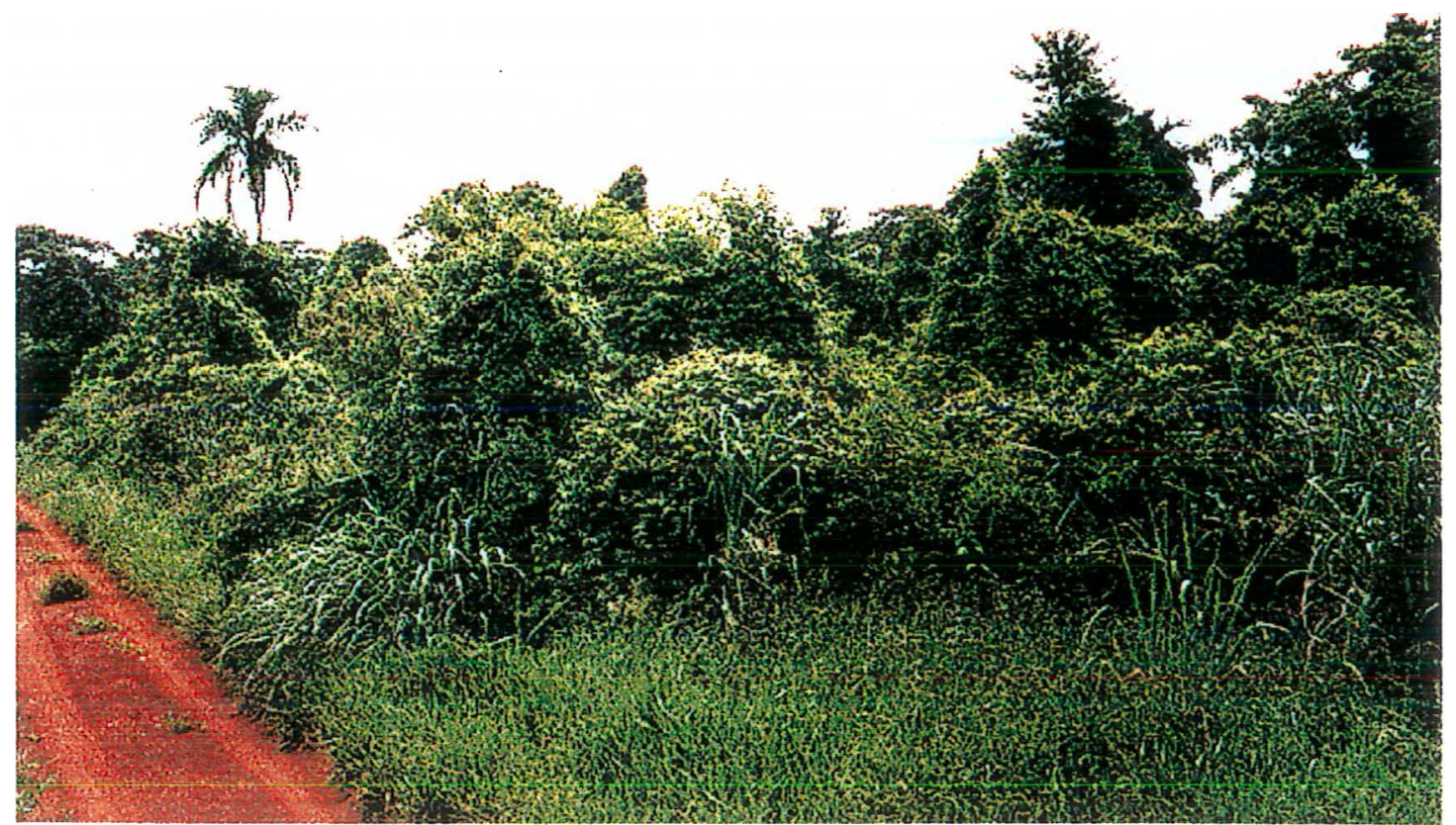

Figura 25 - faixa com cerca de $5 \mathrm{~m}$ de largura, apresentando predominantemente a espécie Brachiaria decumbens (Braquiária) e algumas touceiras de Panicum maximum (Capim-colonião), Reserva Municipal de S anta Genebra, Campinas, SP. 
As espécies de maior densidade foram as lianas: Stigmaphyllon labandiamum, Merremia macrocalyx e Serjania communis.

Os indivíduos emergentes apresentavam-se isolados, chegando a atingir cerca de 25 a $30 \mathrm{~m}$ de altura Entre esses indivíduos arbóreos remanescentes de maior porte foram encontradas as espécies Zeyheria tuberculosa (Ipê-felpudo), Cedrela fissilis (Cedro), Centrolobium tomentosum (Araribá), Cariniana legalis (Jequitibá-rosa), Lonchocarpus muehlbergianus (Embira-de-sapo), entre outras. Outros indivíduos arbóreos também foram encontrados na área, tais como Piptadenia gonoacantha (Pau-jacaré), Croton floribundus (Capixingui), Colubrina glandulosa (Saguaragi-vermelho), Astronium graveolens (Guaritá), Peltophorum dubium (Cana-fístula), Casearia sylvestris (Guaçatonga) e Pachystroma longiflorum (Canxim).

As espécies arbóreas que não apresentaram suas copas tomadas por lianas foram Trema micrantha (Crindiúva), Croton priscus, Centrolobium tomentosum (Araribá), Astronium graveolens (Guaritá), Syagrus oleraceae (Guariroba) e Acacia polyphylla (Monjoleiro).

Nessa unidade ecológica foram encontradas 32 famílias, 64 gêneros e 79 espécies. As famílias de maior riqueza florística foram Bignoniaceae com 11 espécies, seguida de Fabaceae com 6, Euphorbiaceae, Rutaceae e Meliaceae com 4 espécies cada.

\subsubsection{Floresta Paludosa (Floresta de brejo)}

Essa unidade ecológica restringe-se à planície de inundação permanente, nas cotas mais baixas da Reserva que se encontram junto às nascentes. Ao contrário das outras unidades ecológica com vegetação florestal na Reserva, essa área apresentou a grande maioria das espécies perenifolias, característica de ambientes com maior disponibilidade de água no solo durante todo ano.

A adaptação das espécies em solos tipicamente encharcados fez com que evolutivamente elas se diferenciassem, resultando em uma florística bem particular (Figura 26). Alguns exemplos das espécies típicas desses ambientes e responsáveis pela 
dissimilaridade florística com as outras unidades ecológicas foram Talauma ovata (Pinha-do-brejo), Tabebuia umbellata (Ipê-amarelo-do-brejo), Tapirira obtusa, Protium heptaphyllum (Mescla), Geonoma brevispatha e Euterpe edulis (Palmito Jussara).

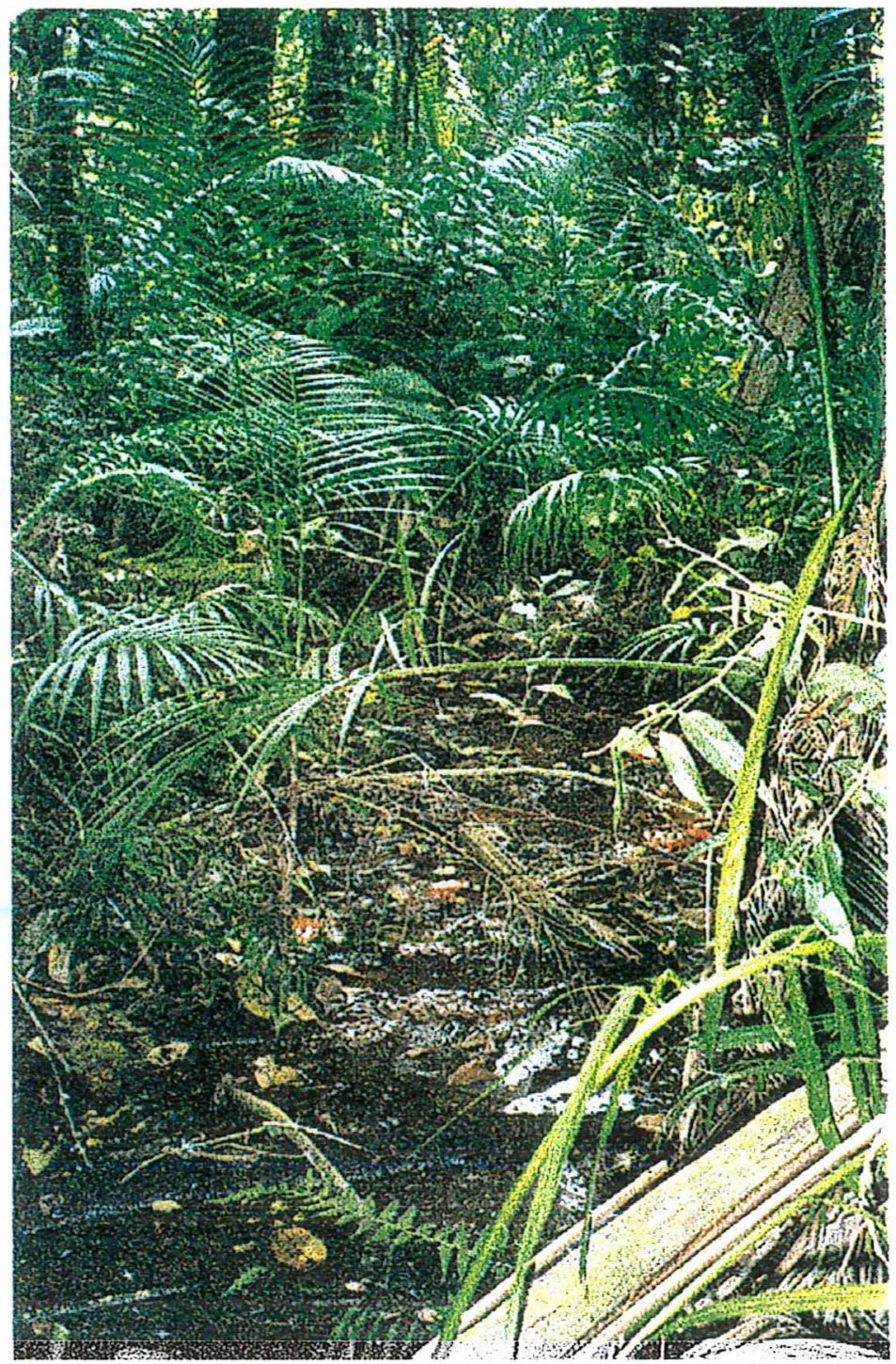

Figura 26 - Detalhe do encharcamento do solo no interior da floresta paludosa, Reserva Municipal de Santa Genebra, Campinas, SP.

O dossel da floresta paludosa atingia cerca de 8 à $12 \mathrm{~m}$ de altura e era composto por espécies como: Euterpe edulis (Palmito Jussara), Protium heptaphyllum (Mescla), Alchornea triplinervia (Tapiá), entre outras. Porém, existem algumas poucas espécies 
emergentes atingindo mais de $15 \mathrm{~m}$ de altura como Tabebuia umbellata (Ipê-amarelo-dobrejo), Inga luschnathiama (Ingá), Tapirira obtusa e Talauma ovata (Pinha-do-brejo).

Abaixo do dossel existia um sub-bosque pouco definido e caracterizado por indivíduos de pequeno porte variando entre 2 e $5 \mathrm{~m}$ de altura. Neste estrato, além dos indivíduos jovens das espécies mais altas, ocorrem principalmente espécies Geonoma brevispatha, Sebastiania serrata (Branquilho), Guarea kunthiana (Marinheiro), Psychotria spp, entre outras.

Apesar do maior grau de umidade dessas florestas que possibilita a existência de epífitas, foi constatado poucos indivíduos dessa forma de vida.

Nessa unidade ecológica foram encontradas 39 famílias e 105 espécies. A família de maior riqueza florística foi Myrtaceae, com 12 espécies, seguida de Rubiaceae e Melastomataceae com 10, Euphorbiaceae e Meliaceae com 8. Esses resultados se diferem bastante das outras unidades ecológicas identificadas entretanto, são parecidos com os resultados obtidos nos trabalhos de Floresta Paludosa por Toniato (1996), Ivanauskas et al. (1997) e Spina (1997), havendo algumas diferenças devido a metodologia de amostragem, que neste caso favoreceu a família Rubiaceae, Meliaceae e Melastomataceae por possuírem muitos indivíduos com diâmetros baixos.

$\mathrm{O}$ indice de diversidade de Shannon $(\mathrm{H})$ obtido para esse trecho de floresta estacional semidecidual foi de 3,47 nats/indivíduos. Esse valor é considerado bem alto quando comparados com outros trabalhos dessa mesma unidade fitogeográfica $(2,75$ nats/indivíduos para Ivanauskas et al. (1997) e 2,45 nats/indivíduos em Torres et al., 1994). Essa desigualdade é causada pela condição ecotonal dessa unidade, com interface com as demais unidades ecológicas da Reserva e devido ao método de inclusão de indivíduos na amostragem (maior que $1 \mathrm{~m}$ de altura).

Neste levantamento as espécies de maior valor de importância (IVI) foram Euterpe edulis (Palmito Jussara) com 38,02, seguida de Geonoma brevispatha com 27,72, Inga marginata (Ingá) com 21,24, Tapirira guianensis (Pau-pomba) com 16,40 e Protium cf. heptaphyllum (Mescla) com 13,18. Os parâmetros fitossociológico desta unidade se encontra no anexo B. 


\subsubsection{Maciço de maria-preta (Diatenopteryx sorbifolia Radlk.)}

Essa unidade ecológica encontrou-se localizada na parte central da Reserva, com características fisionômicas e estruturais muito particulares, apresentando um dossel contínuo, muito bem definido, de porte superior ao restante da floresta, composto praticamente por uma só espécie, o Diatenopteryx sorbifolia Radlk. (Maria-Preta). O dossel apresentou-se de forma contínua com cerca de 25 a $30 \mathrm{~m}$ de altura não apresentando indivíduos emergentes.

Esse trecho de floresta apresentou apenas dois estratos bem definidos, o dossel e o sub-bosque. O dossel predominado pelos indivíduos de Diatenopteryx sorbifolia Radlk. (Figura 27), apresentou indivíduos com copas grandes e largas e deciduidade sazonal bem marcante que permitia a entrada de grande luminosidade no estrato inferior, constituído pelo sub-bosque. Esse ambiente pouco perturbado, com baixa densidade de lianas e poucas clareiras geralmente pequenas, permite o fácil deslocamento dentro dessa unidade ecológica.

O sub-bosque apresentou espécies com um porte variando entre 1,5 a $4 \mathrm{~m}$ de altura, sendo representado principalmente por espécies como o Actinostemon klotschii, Sebastiania serrata (Branquilho), Metrodorea nigra (Chupa-ferro), Coffea arabica (Café), Trichilia spp, entre outras.

Apesar das espécies mais representativas do sub-bosque dessa área terem sido consideradas também comuns em outras unidades como "áreas sem indícios de perturbação recente", este estrato apresentou várias outras espécies exclusivas. Essas espécies eram principalmente das famílias Myrtaceae e Rubiaceae, as quais foram responsáveis pela separação desta unidade ecológica do restante, nas análises de similaridade. 


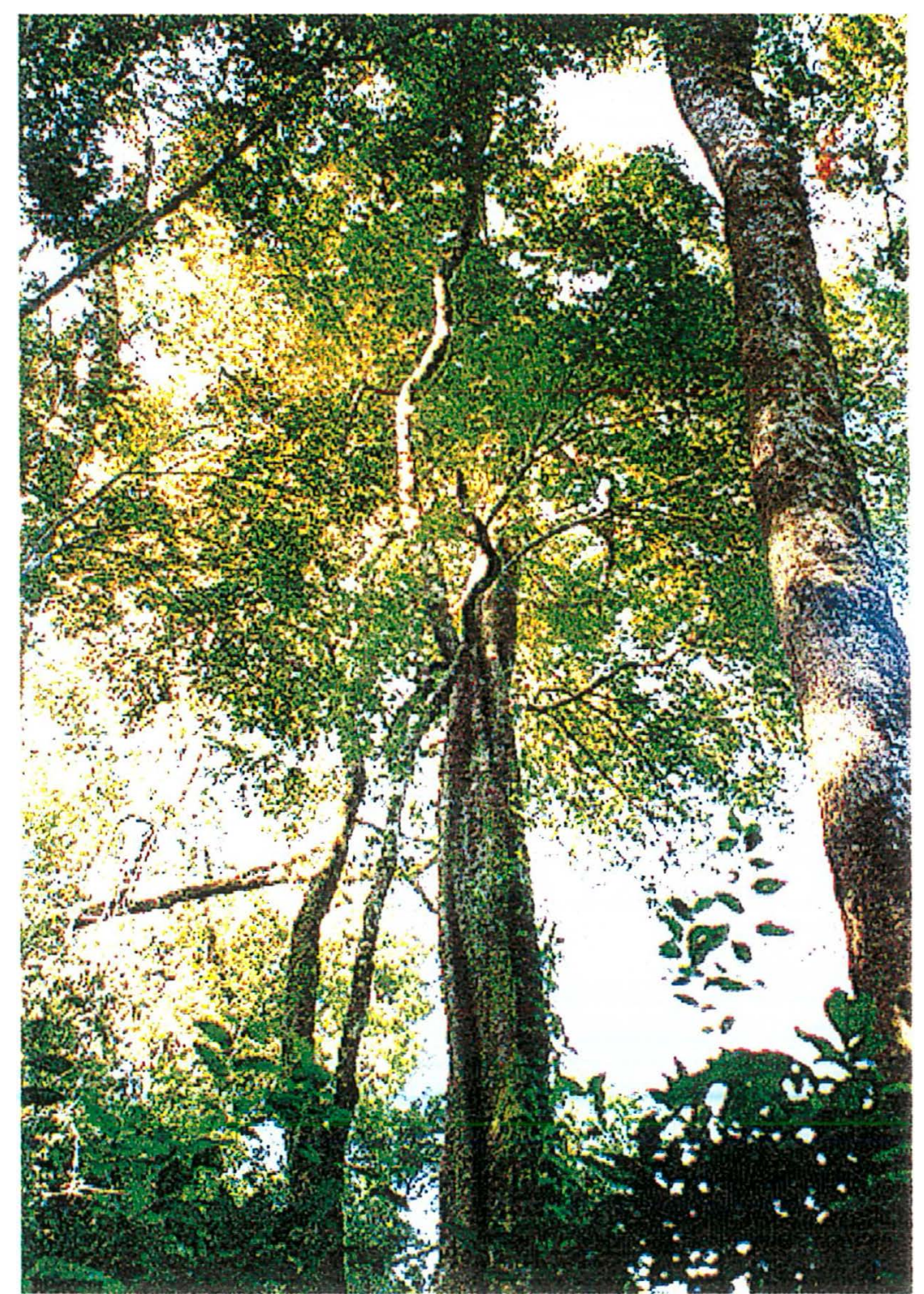

Figura 27 - Detalhe do tronco profundamente sulcado do Diatenopteryx sorbifolia Radlk. (Maria-preta): espécie de maior IVI e IVC dessa unidade ecológica, Reserva Municipal de Santa Genebra, Campinas, SP.

Nessa unidade ecológica foram encontradas 39 famílias e 93 espécies. A família de maior riqueza florística foi Myrtaceae, com 16 espécies, seguida de Rubiaceae com 12, Meliaceae, Euphorbiaceae, Rutaceae, Fabaceae e Lauraceae com 5 espécies cada.

$\mathrm{O}$ índice de diversidade de Shannon $\left(\mathrm{H}^{\prime}\right)$ obtido para esse trecho de floresta estacional semidecidual foi de 2,539 nats/indivíduos. Esse valor foi considerado muito 
baixo quando comparados com outros trabalhos dessa mesma unidade fitogeográfica. Essa diferença de diversidade reforçam ainda mais as particularidades dessa área e dissimilaridade com as outras unidades ecológicas.

As espécies de maior valor de importância foram Diatenopteryx sorbifolia Radlk. (Maria-preta) com 69,18, seguida de Actinostemon klotschii com 52,49, Metrodorea nigra (Chupa-ferro) com 20,77, Aspidosperma polyneuron (Peroba-rosa) com 14,48, Sebastiania serrata (Branquilho) com 13,82 e Coffea arabica (Café) com 12,89. Os parâmetros fitossociológico desta unidade se encontra no Anexo C.

A baixa diversidade e o IVI apresentado pela Diatenopteryx sorbifolia Radlk. sugere a possibilidade de efeito alelopático dessa espécie sobre outras plantas. Entretanto, essa possibilidade não foi estudada nesse trabalho.

\subsubsection{Clareiras}

As clareiras apresentaram físionomia semelhante às unidades ecológicas "faixa com efeito de borda" e "área queimada", caracterizada pela ausência de dossel e estrato predominantemente herbáceo-arbustiva com a presença vários indivíduos arbóreos jovens, geralmente pertencentes ao estágio inicial da sucessão (Figura 28). A presença de algumas espécies de lianas em desequilíbrio também foi fato marcante nessas áreas, muitas vezes formando emaranhados por cima da vegetação arbustiva.

No conjunto de 10 clareiras amostradas por Martins (1999), foram amostradas 105 espécies pertencentes a 41 famílias e 79 gêneros. Do total de espécies, apenas 3 ocorreram em todas as parcelas (Coffea arabica, Polygala klotschii e Aspidosperma polyneuron) e 33 espécies esteve presente em apenas uma clareira.

As espécies mais numerosas foram Coffea arabica (Café), Hybanthus atropurpureus, Actinostemon klotschii, Polygala klotschii, Galipea multiflora e Psychotria hastisepala. Algumas espécies de estágio avançado de sucessão como o Aspidosperma polyneuron (Peroba-rosa), Holocalyx balanse (Alecrim-de-campinas) e o 
Pachystroma longifolium (Canxim), também se destacaram em densidade apresentandose como indivíduos jovens.

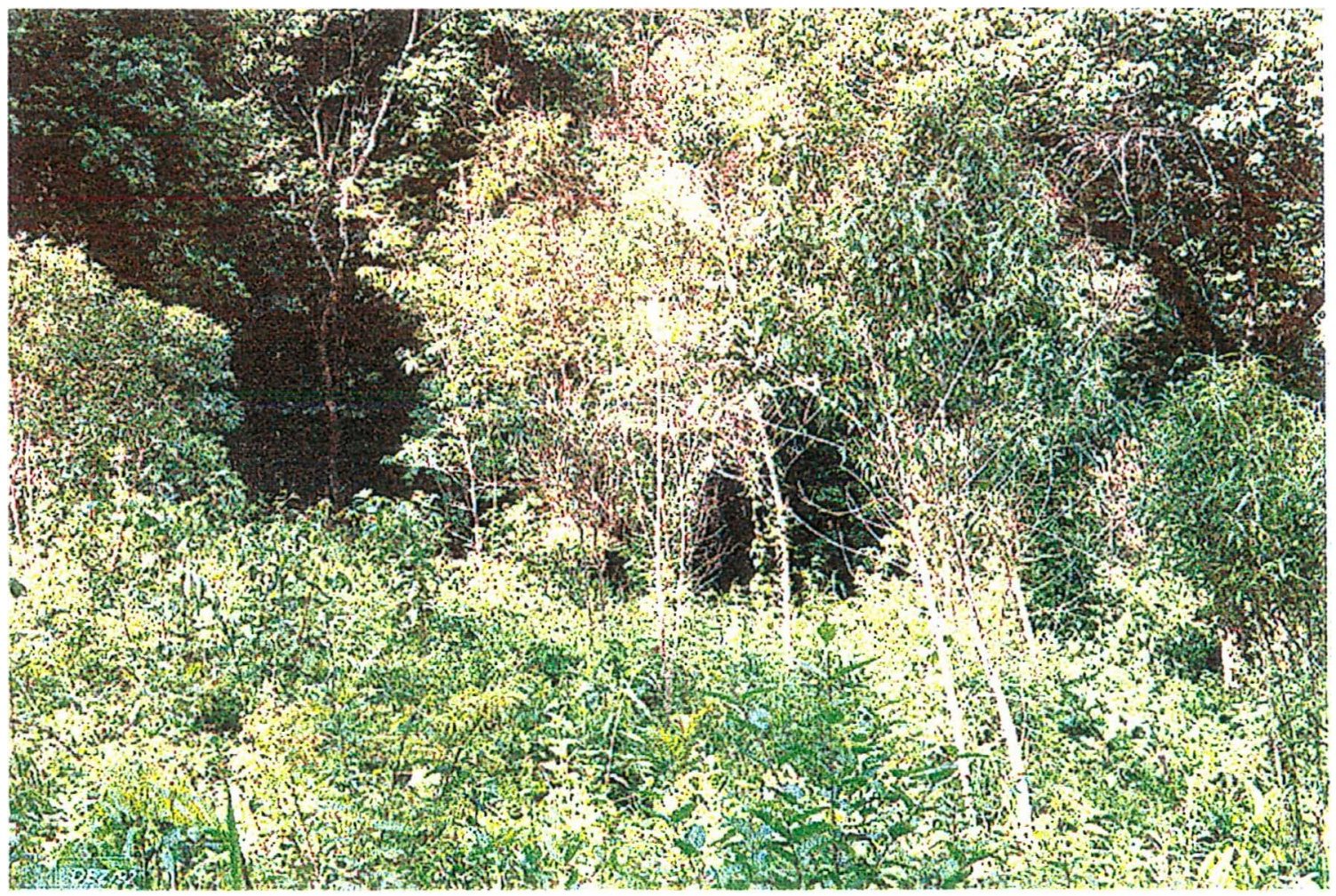

Figura 28 - Vista do interior de uma clareira, Reserva Municipal de Santa Genebra, Campinas, SP

A família de maior riqueza florística foi Rutaceae com 10 espécies, Rubiaceae com 9, seguida de Euphorbiaceae com 7, Myrtaceae, Fabaceae e Meliaceae com 5 cada e Piperaceae e Mimosaceae com 4 (Martins, 1999). Se considera-se as famílias Caesalpiniaceae, Fabaceae e Mimosaceae como uma única família, ou seja, a família Leguminosae de acordo com o sistema de Engler citado por Joly (1977), esta apresentaria a maior riqueza, com 13 espécies. 


\subsection{Similaridade vegetacional entre as unidades ecológicas}

\subsubsection{Análise florística (qualitativa)}

Os índices de Sorensen obtidos e sugerido por diversos autores para esse tipo de análises (Gauch, 1981; Hill, 1979b; Prentice, 1980; Sockal \& Rohlf, 1995), foram submetidos a uma análise de aglomerados (cluster) de modo a obter o dendrograma que mostrou o grau de similaridade entre as unidades ecológicas. A ligação entre as unidades ecológicas baseou-se na média de grupo (UPGMA), onde o agrupamento é feito a partir da média aritmética dos seus elementos. A Figura 29 apresenta o dendrograma obtido através da análise qualitativa das parcelas de todas as unidades ecológicas.

De modo geral, esse dendrograma apresentou um agrupamento extremamente coerente com a definição das unidades ecológicas, tendo separado claramente 6 grupos sendo: "áreas sem indícios de perturbação recente", "áreas com indícios de perturbação recente", "maciço de Maria-preta", Clareiras, Floresta paludosa e "faixa com efeito de borda" junto com a "área queimada". Isso coincide em grande parte com as unidades definidas na fotointerpretação.

Todas as parcelas foram muito bem agrupadas nas suas devidas unidades ecológicas com exceção de algumas pertencentes as unidades "áreas sem indícios de perturbação recente", que se agruparam com as parcelas das "áreas com indícios de perturbação recente" e vice-versa. Essa mistura de parcelas em grupos de unidades ecológicas diferentes é compreensível pelo fato da amostragem ter sido realizada em áreas com fisionomias heterogêneas. Dessa forma, as parcelas foram locadas em áreas onde havia um mosaico sucessional representado por mais de uma unidade ecológica. Portanto, apesar dessas unidades terem sido classificadas diferencialmente, alguns trechos de amostragem eram semelhantes. A heterogeneidade da amostragem desses ambientes pode ser observada no grupo de "áreas sem indícios de perturbação recente", onde existem vários subgrupos apresentado grandes diferenças de similaridade.

Nessa análise, os grupos que apresentaram maior dissimilaridade em relação as outras unidades ecológicas foram a "faixa com efeito de borda" e "área queimada" que 
saíram no dendrograma como um único grupo subdividido em 2 subgrupos distintos, mais com menor dissimilaridade quando comparados aos outros grupos. Estes fatos estão relacionados principalmente com a amostragem de espécies com ocorrência típica na forma de lianas que predominavam esses ambientes definindo a fisionomia, a florística e estrutura e por isso não poderiam deixar de ser amostradas. Entretanto, características próprias de cada um dessas unidades fizeram com que fossem subdivididas separadamente.

Outros grupos que se destacaram em relação a dissimilaridade com o resto das unidades foram a "floresta paludosa", o "maciço de Maria-preta" e as "clareiras", sendo que a "floresta paludosa" apresentou o segundo menor índice de similaridade.

$\mathrm{Na}$ análise de ordenação das unidades ecológicas foi utilizado o método de coordenadas principais (PCO). Este método evidenciou os mesmos grupos identificados na análise de classificação, com exceção das clareiras que não foram claramente isoladas das "áreas sem indícios de perturbação recente" e as "áreas com indícios de perturbação recente". Isso já era esperado por que as clareiras são unidades da floresta resultantes da dinâmica florestal e independente de perturbação ou fragmentação, sendo encontrada também em ambientes mais preservados como o da unidade “áreas sem indícios de perturbação recente". Além disso, as clareiras apresentaram recrutamento de indivíduos jovens de espécies finais de sucessão que, embora não dominem o ambiente, apresentavam-se na forma de banco de plântulas, as quais foram amostradas pelo método utilizado (acima de $50 \mathrm{~cm}$ ). 

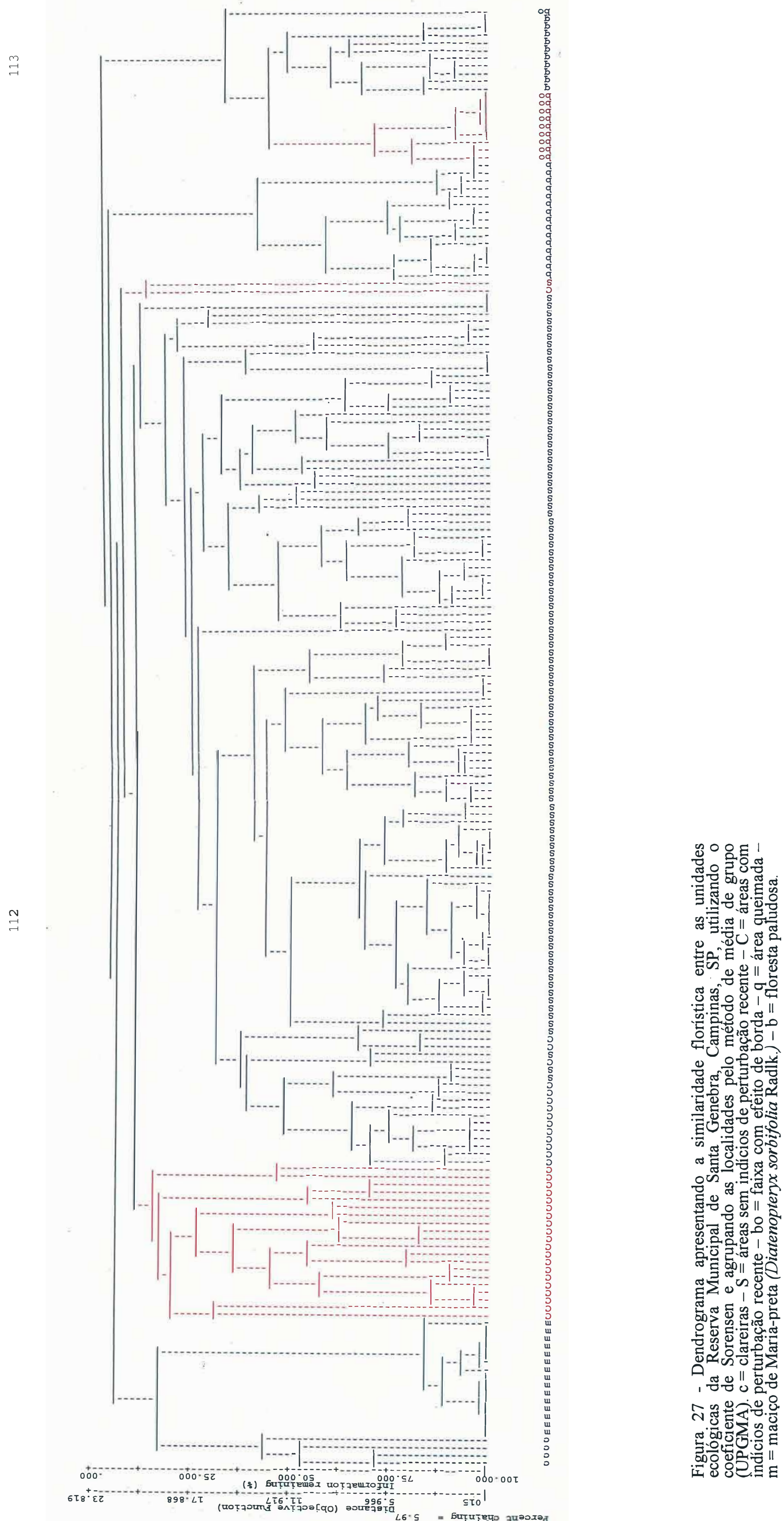
Na Figura 30, mostra o isolamento de 4 grupos. O eixo 1 apresentou ao longo do seu comprimento o isolamento de três grupos de parcelas: a "área queimada" junta com a "faixa com efeito de borda" e a "floresta paludosa" ainda pouco isolada das outras unidades "áreas sem indícios de perturbação recente", "áreas com indícios de perturbação recente", "clareiras", e "maciço de maria-preta ("Diatenopteryx sorbifolia Radlk.").

O eixo 2 destacou o grupo da unidade ecológica "maciço de Maria-preta (Diatenopteryx sorbifolia Radlk.)" e "floresta paludosa" na parte inferior do gráfico das “áreas com e sem indícios de perturbação recente".

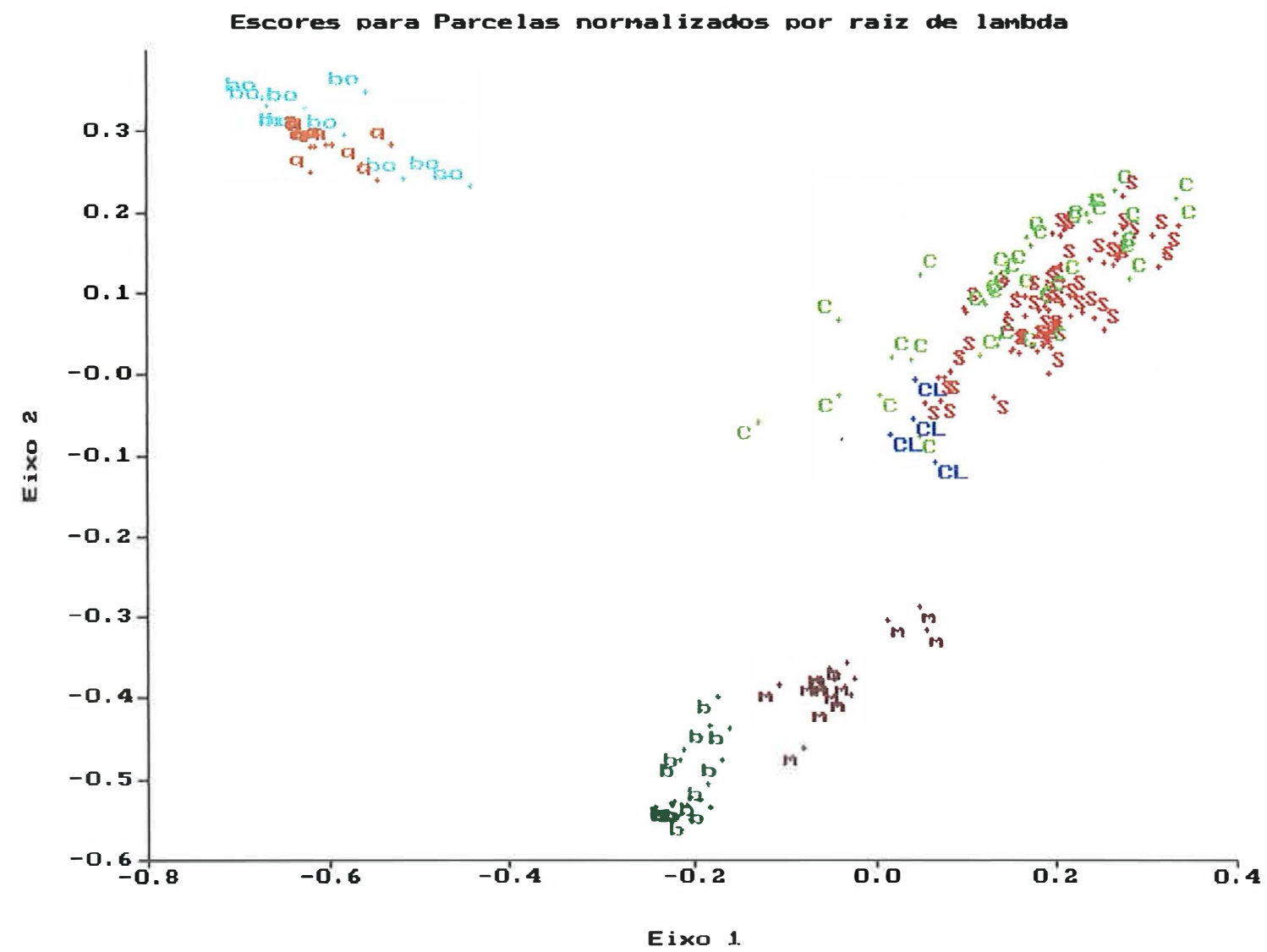

Figura 30 - Diagrama de ordenação das unidades ecológicas amostradas, com base nos eixos 1 e 2 da PCO (Ordenação das Coordenadas Principais), através dos dados de presença e ausência de espécies amostradas nos levantamentos florísticos da Reserva Municipal de Santa Genebra, Campinas, SP. CL = clareiras $-\mathrm{S}=$ áreas sem indícios de perturbação recente $-\mathrm{C}=$ áreas com indícios de perturbação recente - bo $=$ faixa com efeito de borda $-\mathrm{q}=$ área queimada $-\mathrm{m}=$ maciço de Maria-preta (Diatenopteryx sorbifolia Radlk.) - $\mathrm{b}=$ floresta paludosa (floresta de brejo). 
Na Figura 31, que mostra a ordenação dos eixos 1 e 3, com isolamento de 5 grupos. O eixo 3 separou as unidades ecológicas em grupo com parcelas "maciço de Maria-preta", outro com “áreas sem indícios de perturbação recente”, "clareiras", "área queimada" e "faixa com efeito de borda" e outro grupo com "áreas com indícios de perturbação recente" e "floresta paludosa". O eixo 1 separou as parcelas do grupo "áreas sem indícios de perturbação recente" e "clareiras" da "área queimada" e "faixa com efeito de borda" e também as parcelas da unidade "áreas com indícios de perturbação recente" da "floresta paludosa".

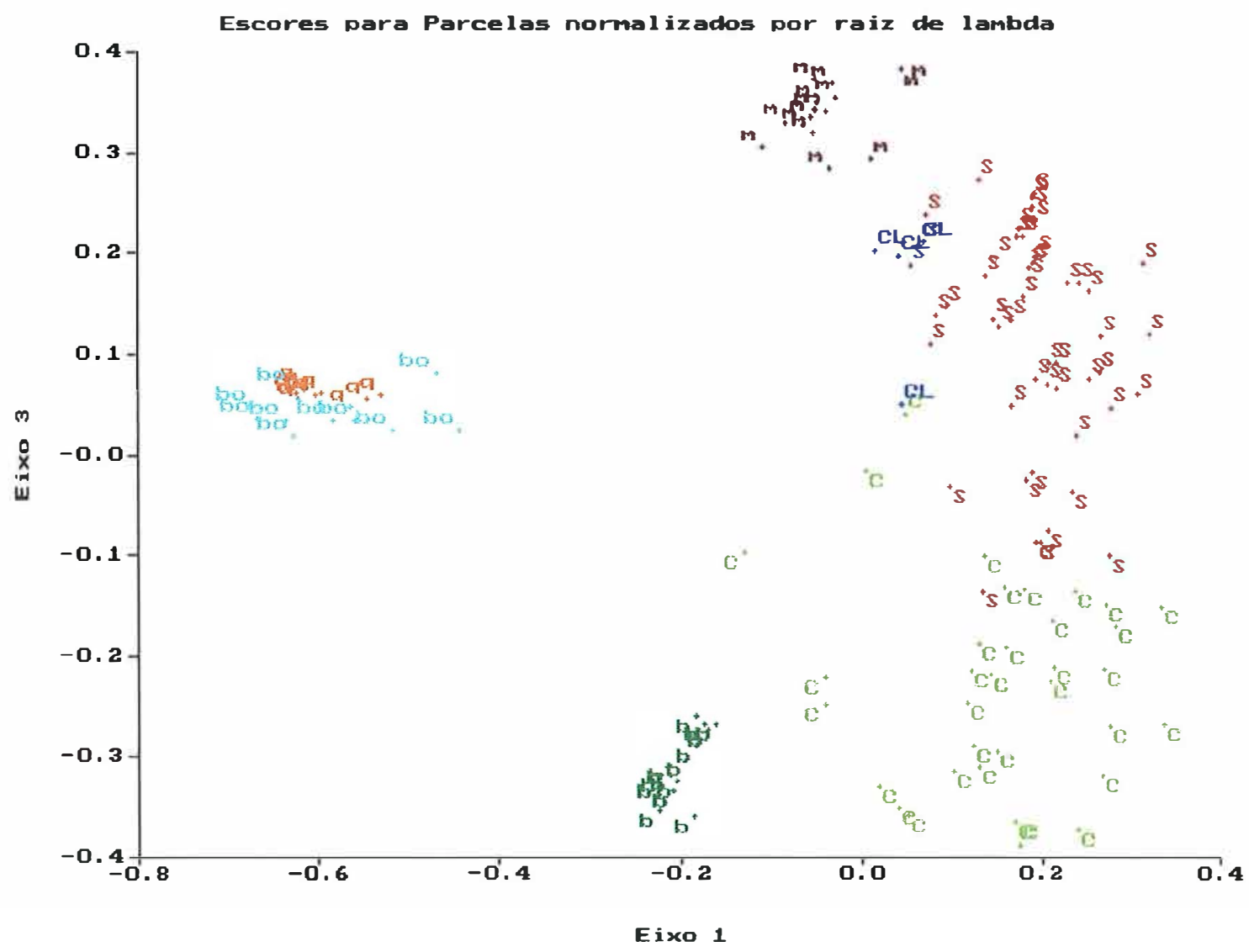

Figura 31 - Diagrama de ordenação das unidades ecológicas amostradas, com base nos eixos 1 e 3 da PCO (Ordenação das Coordenadas Principais), através dos dados de presença e ausência de espécies amostradas nos levantamentos florísticos da Reserva Municipal de Santa Genebra, Campinas, SP. CL = clareiras $-\mathrm{S}=$ áreas sem indícios de perturbação recente $-\mathrm{C}=$ áreas com indícios de perturbação recente - bo $=$ faixa com efeito de borda $-\mathrm{q}=$ área queimada $-\mathrm{m}=$ maciço de Maria-preta (Diatenopteryx sorbifolia Radlk.) - b = floresta paludosa (floresta de brejo). 
A alta similaridade das parcelas das unidades "faixa com efeito de borda" e "área queimada" se deve principalmente pela amostragem da maior parte das espécies na forma de lianas, na maioria pertencentes a família Bignoniaceae e Malpighiaceae, predominante nessas unidades. A abundância do número de espécies dessa forma de vida nesse tipo de ambiente, fez com que essa unidade ecológica apresentasse várias espécies exclusivas, facilitando a sua diferenciação das outras unidades nas análises de similaridade. Entretanto, o dendrograma mostrou que essas unidades apresentavam diferenças florísticas entre si, agrupando-as separadamente.

A flora diferenciada da unidade ecológica floresta paludosa fez com que ela apresentasse o baixa similaridade, diferenciando-se das outras unidades ecológicas. Essa dissimilaridade com as outras unidades ecológicas foi causada pela florística distinta entre duas unidades fitogeográficas (floresta Paludosa e floresta Estacional Semidecidual), caracterizando o mosaico ambiental da Reserva.

A unidade ecológica "maciço de Maria-preta" se destacou bastante nas análises de ordenação, sendo que provavelmente, a diferenciação dessa unidade ecológica está relacionada com as condições edáficas, definindo a heterogeneidade vegetacional em áreas contínuas de floresta, como já dito por diversos autores.

\subsubsection{Análise quantitativa}

Essas análises quantitativas foram realizadas no sentido de complementar as informações obtidas através dos resultados das análises qualitativas, contribuindo para um maior detalhamento da similaridade entre as unidades ecológicas.

Para realização dessas análises, as unidades ecológicas foram divididas em 2 grupos em função das diferentes metodologias de amostragem usadas na caracterização das unidades ecológicas, de forma a permitir uma comparação quantitativa. Sendo assim, formou-se 2 grupos. O primeiro continha as parcelas das unidades "áreas sem indícios de perturbação recente" e "áreas com indícios de perturbação recente" que usaram como metodologia de amostragem a inclusão de indivíduos com PAP $>=15 \mathrm{~cm}$. O segundo 
grupo continha as outras unidades ecológicas, que são as clareiras, a "faixa com efeito de borda", a "área queimada", o maciço de maria-preta e a floresta paludosa, que usaram como metodologia de amostragem a inclusão dos individuos com altura superior a 1 metro.

A comparação entre amostragens realizadas em diferentes tamanhos de área para algumas unidades foi possivel pela utilização do conceito de suficiência amostral para caracterização florística (curva espécie X área).

Do mesmo modo que para as análises qualitativas, os indices de Sorensen obtidos para os grupos de unidades ecológicas foram submetidos a uma análise de aglomerados (cluster) de modo a obter os dendrogramas apresentados nas Figuras 32 e 33, mostrando o grau de similaridade entre as unidades ecológicas. A ligação entre as unidades ecológicas baseou-se na média de grupo (UPGMA), onde o agrupamento é feito a partir da média aritmética dos seus elementos. As Figuras 32 e 33 apresentam os dendrogramas obtido através da análise quantitativa das parcelas dos 2 grupos de unidades ecológicas.

$\mathrm{Na}$ análise realizada para as parcelas das unidades das unidades "áreas sem indícios de perturbação recente" e "áreas com indícios de perturbação recente", o dendrograma apresentou dois grandes grupos os quais separam muito bem as unidades ecológicas. No entanto, esse dendrograma também apresentou mais 3 pequenos agrupamentos com baixa similaridade com o restante das parcelas. Esses resultados novamente refletem a heterogeneidade do ambiente onde foram locadas as parcelas, englobando condições ecotonais do gradiente sucessional. 


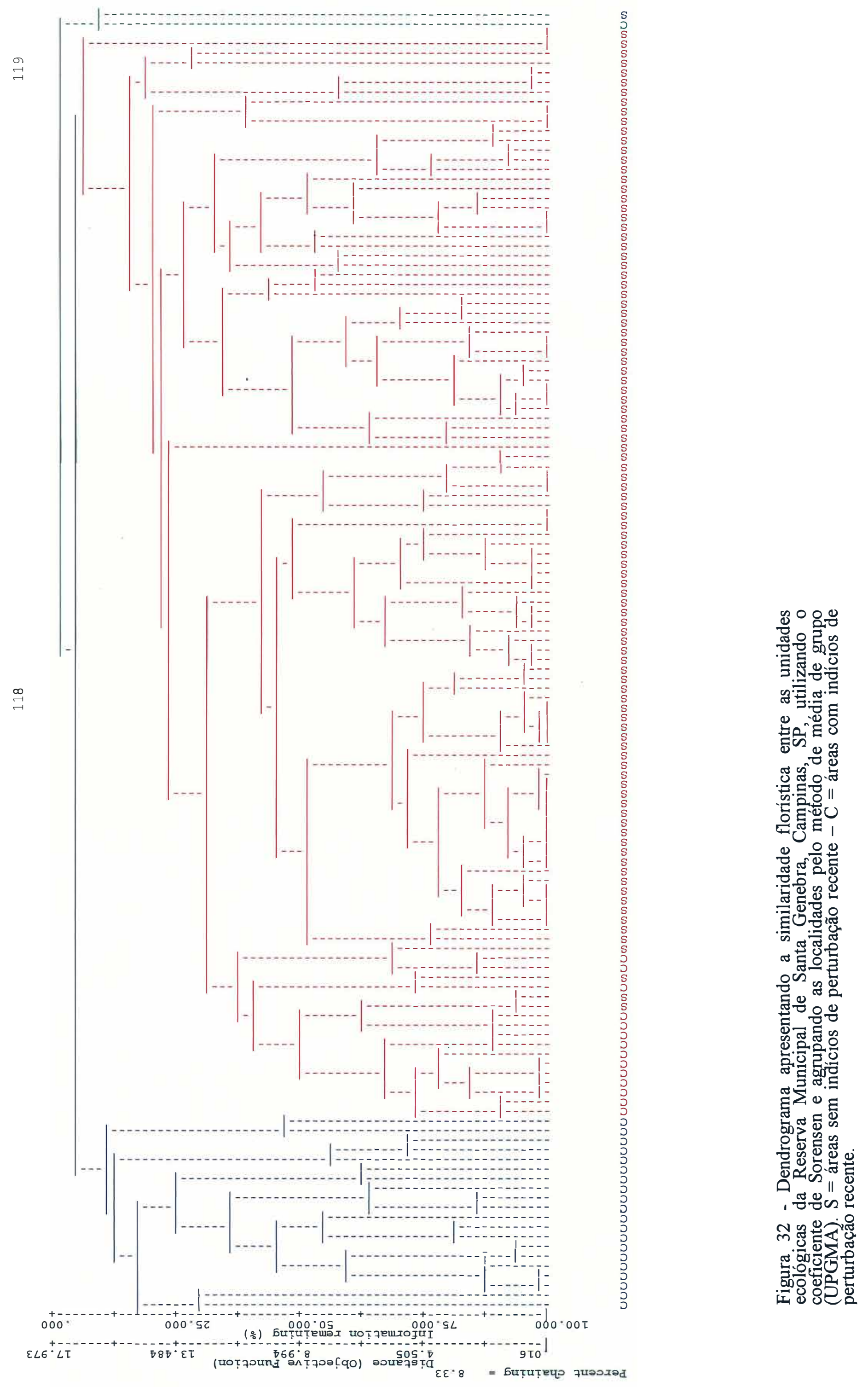


Figura 33 - Dendrograma apresentando a similaridade florística entre as unidades ecológicas da Reserva Munícipal de Santa Genebra, Campinas, SP, utilizando o coeficiente de Sorensen e agrupando as localidades pelo método de média de grupo $($ UPGMA). $\mathrm{c}=$ clareiras $-\mathrm{bo}=$ faixa com efeito de borda $-\mathrm{g}=$ área queimada $-\mathrm{m}=$ maciço de Maria-preta (Diatenopteryx sorbifolia Radlk.) - b = floresta paludosa.

Percent chaining $=4.10$

Distance (Objective Function)

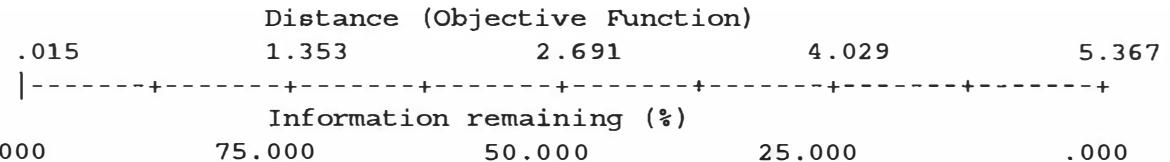

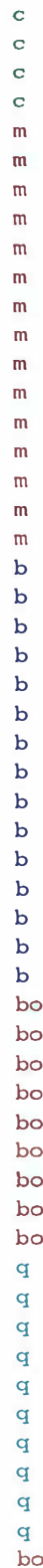
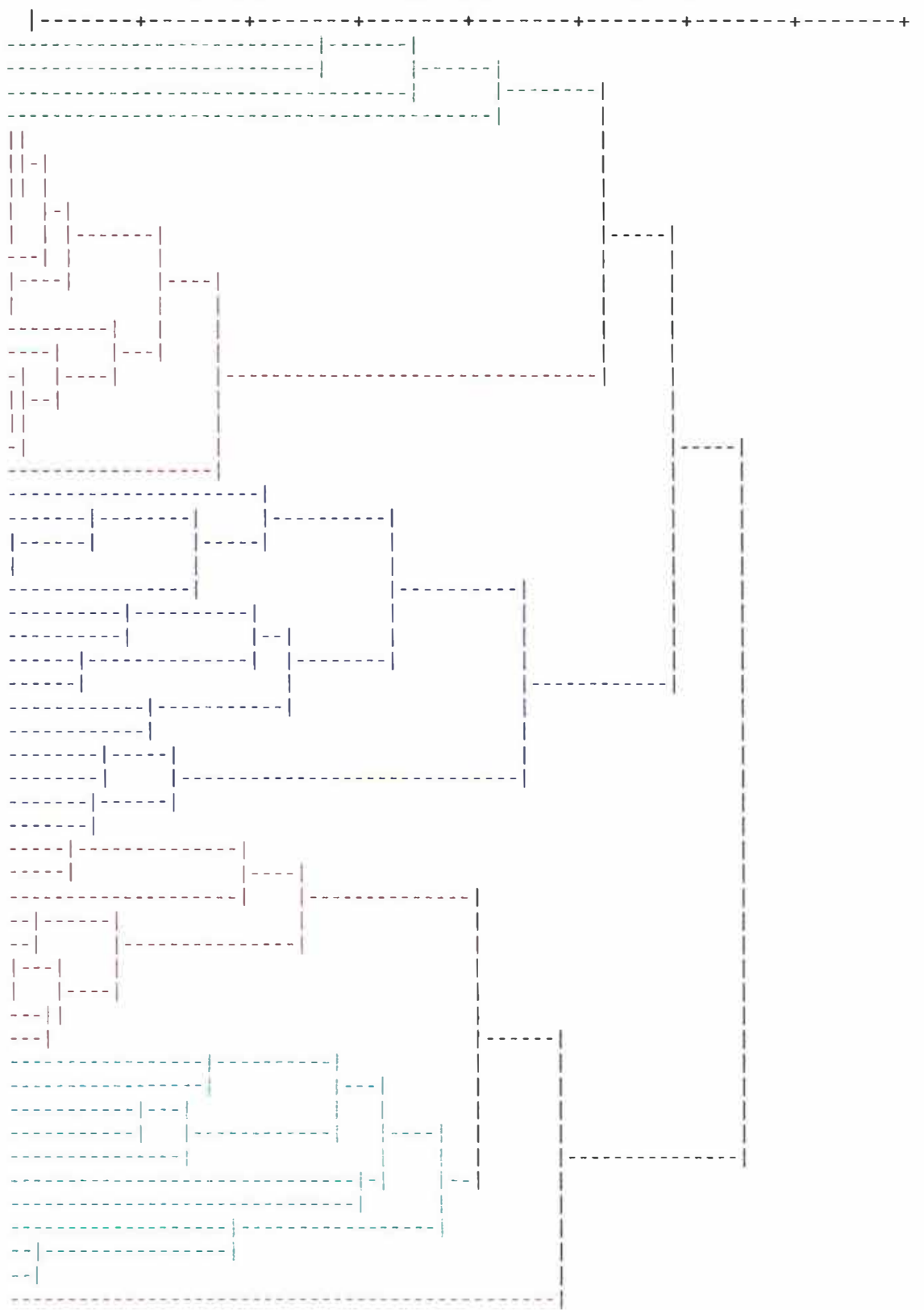
Os resultados obtidos para as unidades "faixa com efeito de borda", "área queimada", "clareiras", "floresta paludosa" e "maciço de maria-preta (Diatenopteryx sorbifolia Radlk.)", praticamente foram iguais aos resultados já obtidos nas análises qualitativas. As parcelas das unidades ecológicas se agruparam, apresentando baixa similaridade entre si, com exceção da "faixa com efeito de borda" e "área queimada" que se apresentaram como 4 subgrupos de relativa similaridade. A floresta paludosa novamente se destacou em relação a dissimilaridade com o resto das unidades.

A análise de ordenação usando os dados quantitativos das parcelas das unidades ecológicas foi realizada através da Análise de Componentes Principais (PCA), usando o método NONCENTERED, disponivel no programa PC - ORD para Windows.

Os resultados das análises realizadas com as parcelas das unidades "áreas sem indícios de perturbação recente", "áreas com indícios de perturbação recente", pode ser observada na Figura 34 e os valores de variação dos eixos na Tabela 26. Em nenhum dos eixos houve a separação de grupos das 2 unidades. Notou-se apenas uma distribuição mais dispersa pelo gráfico da unidade "áreas sem indícios de perturbação recente", comprovando uma maior heterogeneidade da amostragem dessa área e colocando as "áreas com indícios de perturbação recente" como uma sub-unidade da anterior e pertencendo a mesma formação. 


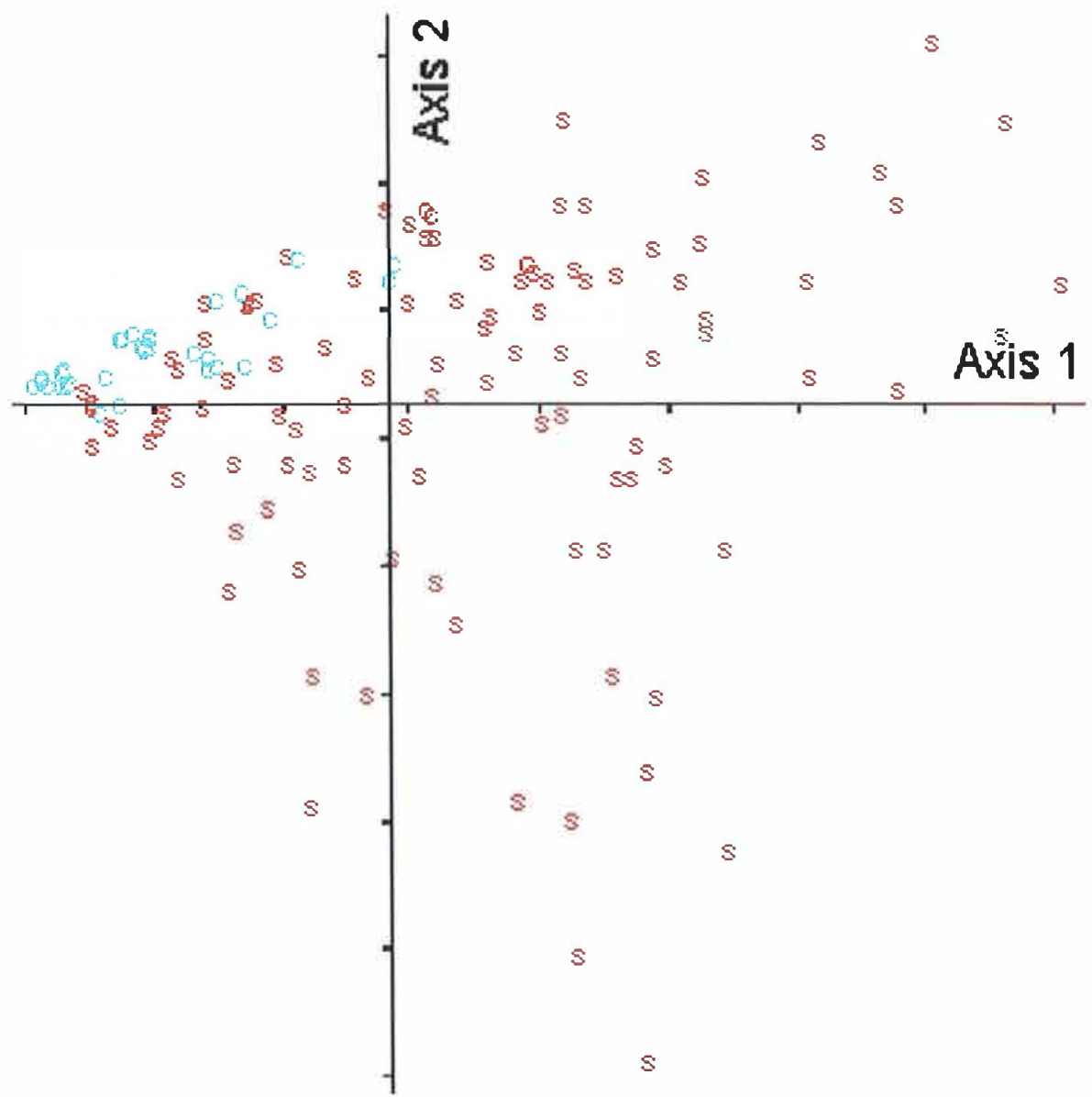

Figura 34 - Diagrama de ordenação das unidades ecológicas amostradas, com base nos eixos 1 e 2 da PCA, através dos dados quantitativos das espécies amostradas na Reserva Municipal de Santa Genebra, Campinas, SP. $\mathrm{S}$ = áreas sem indícios de perturbação recente $-\mathrm{C}=$ áreas com indícios de perturbação recente.

Tabela 26 - Valores de variação dos 10 primeiros eixos (NONCENTERED)

$\begin{array}{rrrrr}\text { AXIS } & \text { Eigenvalue } & \% \text { of Variance } & \text { Cum. } \% \text { of Var. } & \begin{array}{l}\text { Broken-stick } \\ \text { Eigenvalue }\end{array} \\ 1 & 1935.558 & 44.060 & 44.060 & 204.922 \\ 2 & 604.054 & 13.750 & 57.810 & 166.386 \\ 3 & 381.186 & 8.677 & 66.488 & 147.119 \\ 4 & 231.109 & 5.261 & 71.748 & 134.274 \\ 5 & 198.561 & 4.520 & 76.268 & 124.640 \\ 6 & 152.236 & 3.465 & 79.734 & 116.933 \\ 7 & 110.911 & 2.525 & 82.259 & 110.511 \\ 8 & 106.457 & 2.423 & 84.682 & 105.006 \\ 9 & 79.403 & 1.807 & 86.489 & 100.189 \\ 10 & 51.581 & 1.174 & 87.664 & 95.907\end{array}$


Nas análises de ordenação realizada para o restante das unidades ecológicas houve o isolamento de todas as unidades ecológicas, com exceção das unidades "faixa com efeito de borda" e "área queimada" que mais uma vez apresentaram similaridade florística e estrutural. Os resultados dessas análises são apresentados nas Figuras 35 e 36, e os valores de variações dos eixos estão na Tabela 27.

Na Figura 35, o eixo 1 separou as parcelas da floresta paludosa do restante e o eixo 2 separou as parcelas do "maciço de Maria-preta (Diatenopteryx sorbifolia Radlk.)" das unidades restantes". Na Figura 36, o eixo 2 separou as unidades "maciço de Mariapreta (Diatenopteryx sorbifolia Radlk.)" do restante e o eixo 1 separou as parcelas das unidades "faixa com efeito de borda" e "área queimada" da "floresta paludosa", sendo que as parcelas da unidade "clareiras" encontraram-se distribuídas próximas ao eixo.

Nesses dois gráficos nota-se a distribuição de forma quase linear das parcelas de algumas unidades como a "faixa com efeito de borda" e "área queimada", "Floresta paludosa" e o "maciço de Maria-preta (Diatenopteryx sorbifolia Radlk.)". Esse fato revelou o gradiente ambiental que existia nas parcelas amostradas dentro de cada unidade. Sendo assim, as parcelas da unidade ecológica "Floresta paludosa" que apresentou uma grande distribuição ao longo do eixo 2 da Figura 35, provavelmente devem estar respondendo a um gradiente de umidade que diminui em direção ao eixo 1 .

As análises dos dados quantitativos e qualitativos foram muito bem apresentadas nos dendrogramas e diagramas de ordenação, tendo separado em grupos distintos as unidades ecológicas com características semelhantes. 


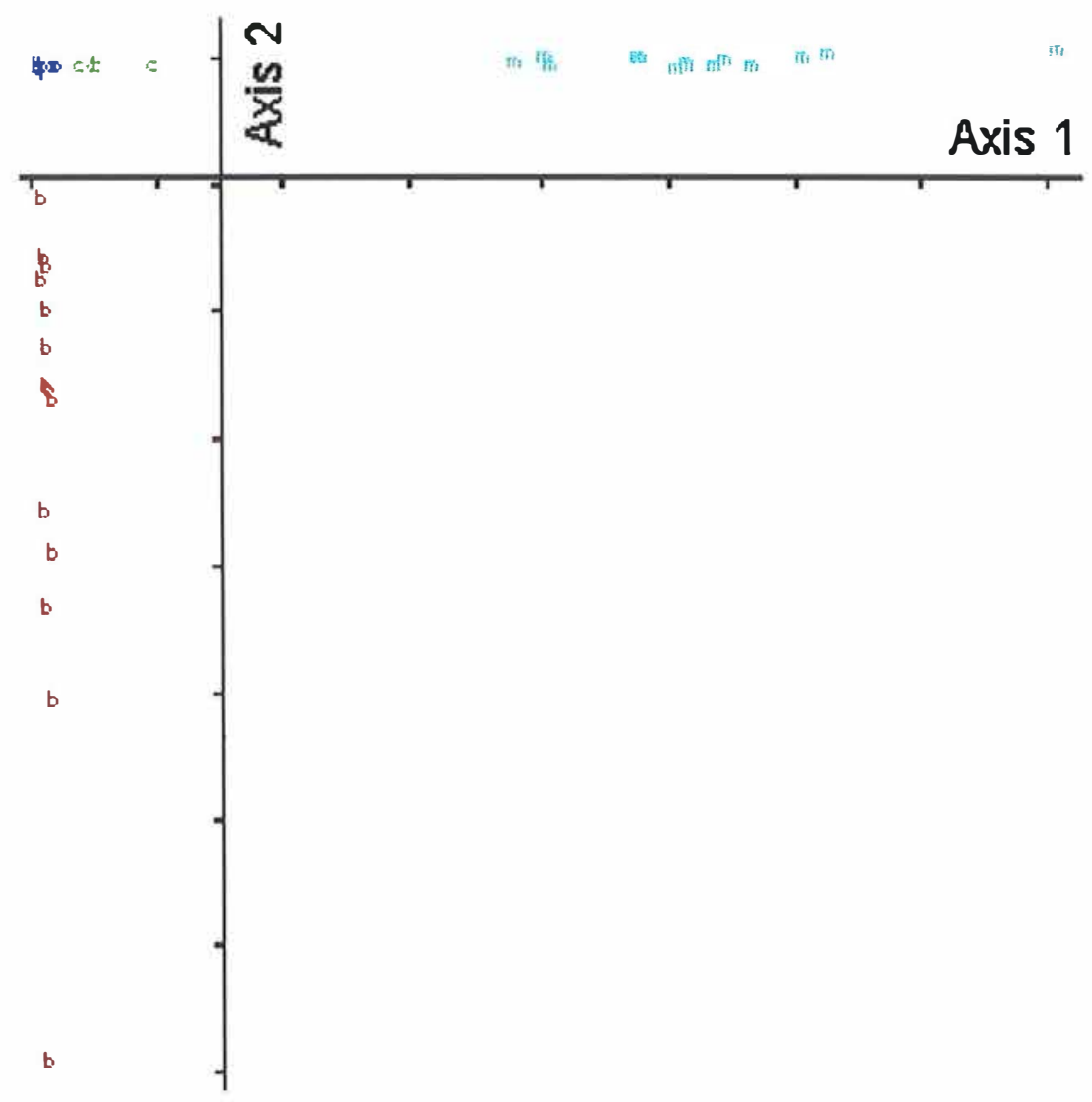

Figura 35 - Diagrama de ordenação das unidades ecológicas amostradas, com base nos eixos 1 e 2 da PCA, através dos dados quantitativos das espécies amostradas na Reserva Municipal de Santa Genebra, Campinas, SP. c = clareiras bo = faixa com efeito de borda $-\mathrm{q}=$ área queimada $-\mathrm{m}=$ maciço de Maria-preta (Diatenopteryx sorbifolia Radlk.) $-\mathrm{b}$ $=$ floresta paludosa.

Tabela 27 - Valores de variação dos 10 primeiros eixos (NONCENTERED)

\begin{tabular}{ccccc} 
AXIS & Eigenvalue & $\%$ of Variance & Cum.\% of Var. & $\begin{array}{l}\text { Voken-stick } \\
\text { Eigenvalue }\end{array}$ \\
\hline 1 & 82599.340 & 56.318 & 56.318 & 6841.575 \\
2 & 23370.810 & 15.935 & 72.253 & 5555.031 \\
3 & 9074.379 & 6.187 & 78.440 & 4911.759 \\
4 & 6704.157 & 4.571 & 83.011 & 4482.911 \\
5 & 5093.258 & 3.473 & 86.484 & 4161.275 \\
6 & 4106.724 & 2.800 & 89.284 & 3903.966 \\
7 & 2171.229 & 1.480 & 90.764 & 3689.542 \\
8 & 1814.078 & 1.237 & 92.001 & 3505.750 \\
9 & 1637.973 & 1.117 & 93.118 & 3344.932 \\
10 & 972.696 & .663 & 93.781 & 3201.983
\end{tabular}




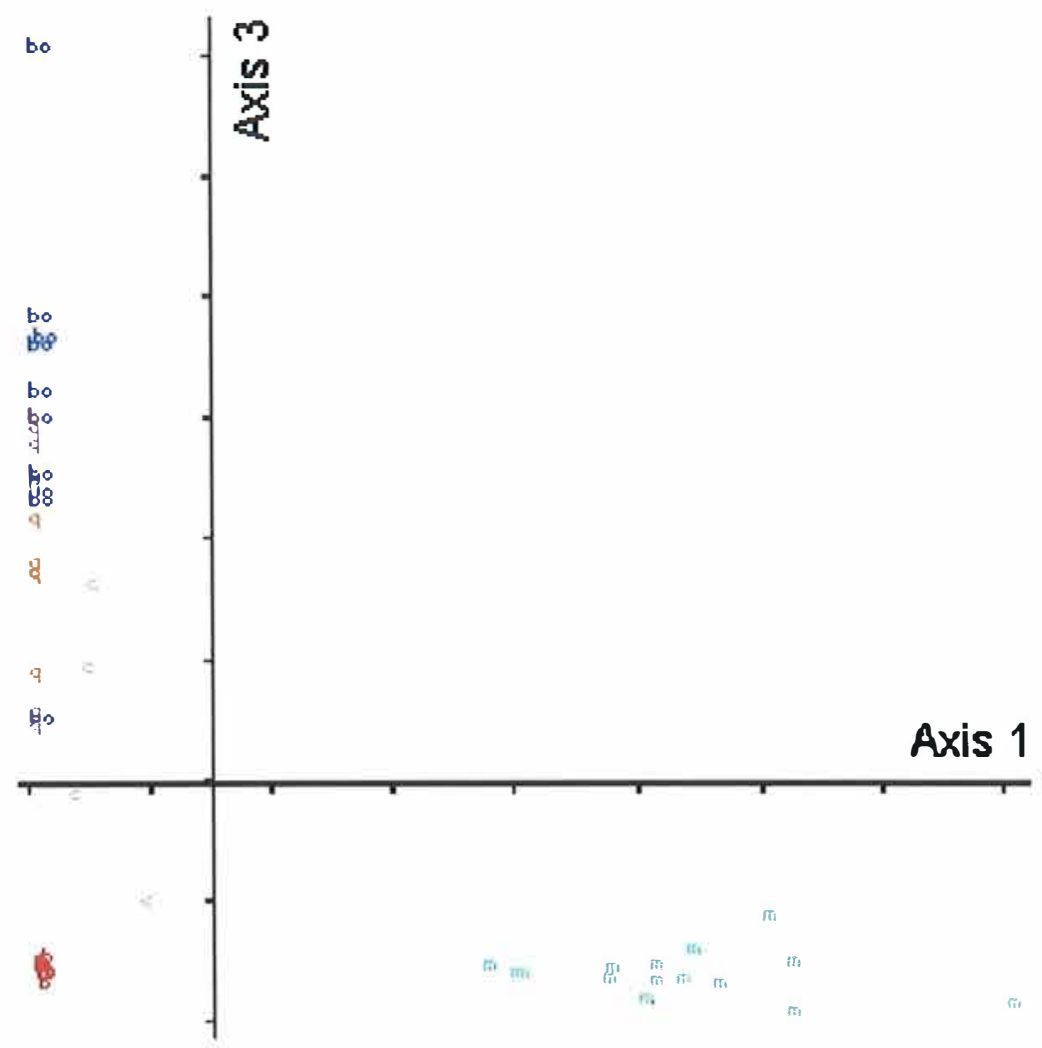

Figura 36 - Diagrama de ordenação das unidades ecológicas amostradas, com base nos eixos 1 e 3 da PCA, através dos dados quantitativos das espécies amostradas na Reserva Municipal de Santa Genebra, Campinas, SP. $\mathrm{c}=$ clareiras bo $=$ faixa com efeito de borda $-\mathrm{q}=$ área queimada $-\mathrm{m}=$ maciço de Maria-preta (Diatenopteryx sorbifolia Radlk.) $-\mathrm{b}$ $=$ floresta paludosa.

Os resultados destas análises de similaridade mostraram as proximidades ou as diferenças entre cada uma das unidades ecológicas. Desse modo, as unidades "faixa com efeito de borda" e "área queimada" foram consideradas as mais semelhantes dentre todas as unidades, apresentando-se como subdivisões de uma mesma comunidade, sendo que se não houvesse um conhecimento do histórico de perturbação da área, elas seriam classificadas como uma única unidade ecológica pelas análises das imagens. Até mesmo a fisionomia dessas unidades eram muito parecidas e suas diferenças só puderam ser reconhecidas nas análises florísticas. Isso reforça a necessidade da checagem de campo nesse tipo de trabalho.

As unidades "áreas sem indícios de perturbação recente" e "áreas com indícios de perturbação recente", também foram classificadas como grupos bem próximos, inclusive 
misturando-se algumas parcelas entre estas unidades. As unidades ecológicas "maciço de maria-preta", "clareiras" e "floresta paludosa" diferenciaram-se bastante das outras unidades e entre si nas análises de agrupamento (Cluster), principalmente a "floresta paludosa", em função da heterogeneidade ambiental e conseqüente diferenciação florística. Todas essas unidades se diferenciam pelo gradiente sucessional, com exceção da unidade floresta paludosa que se diferencia pelo gradiente ambiental.

Outro fator importante é que as diferenças fisionômicas identificadas na fotointerpretação nem sempre representavam unidades ecológicas diferenciadas. As unidades ecológicas "áreas com indícios de perturbação recente" e "floresta de encosta" apresentaram diferenças fisionômicas na classificação das imagens, mas não mostraram diferenças florísticas e estruturais durante a checagem de campo. O mesmo aconteceu com as duas unidades previamente chamadas de complexo ciliar e floresta paludosa. 


\section{CONCLUSÕES}

De um modo geral, todos os métodos utilizados, com exceção das análises texturais e espectrais/texturais, apresentaram resultados interessantes para estudos vegetacionais, com identificação de unidades ecológicas ou do gradiente sucessional.

Nas fotointerpretações, a análise estereoscópica das fotografias aéreas em escala 1:5.000 e a análise analógica de fotografia aérea em formato digital com escala 1:25.000, identificaram o maior número de unidades ecológicas (7), com limites bem definidos.

Nessas análises, as intensas fragmentações de pequenos trechos das unidades ecológicas "áreas com indícios de perturbação recente" e "áreas sem indícios de perturbação recente" foram responsáveis pela maior parte dos erros de interpretação.

$\mathrm{Na}$ análise estereoscópica das fotografias aéreas em escala 1:25.000 e 1:35.000, não foi possível a diferenciação das unidades ecológicas "áreas com indícios de perturbação recente", "áreas sem indícios de perturbação recente" e "clareiras grandes". Nesse método de análise analógica utilizando a estereoscopia, quanto maior a escala melhor a identificação das unidades ecológicas e do nível de detalhamento do mapa.

Nas análises de imagens orbitais, a classificação não supervisionada, que é uma das técnicas mais simples em processamento de imagens, obteve o melhor resultado na identificação do mosaico florestal.

Em geral as classificações orbitais, apesar de terem reconhecido apenas 5 unidades ecológicas (duas a menos que os melhores resultados das fotointerpretações), apresentaram resultados muito promissores para detectar o gradiente sucessional no fragmento estudado, servindo como instrumento de grande utilidade no monitoramento dos processos da dinâmica florestal. 
Tanto o resultado da imagem Landsat - TM, quanto o da SPOT-XS, foram considerados bons, no entanto, a imagem SPOT apresentou vantagem em termos de resolução espacial.

Os resultados obtidos pelos classificadores texturais nas classificações em fotografia aérea e em imagens orbitais foram insatisfatórios, não reconhecendo unidades as identificadas nos outros métodos. Portanto, esse tipo de análise, não deve ser recomendada como metodologia de identificação de unidades ecológicas em fragmentos florestais.

A definição do método mais adequado para identificação do mosaico florestal depende do objetivo do trabalho pretendido. Dessa forma, considerando os critérios como índice Kappa, números de unidades ecológicas identificadas, coerência das unidade e seus limites com a verdade terrestre, tempo de análise, recursos computacionais necessários, disponibilidade territorial, disponibilidade temporal, custo de aquisição e freqüência de uso em trabalhos de vegetação (regional e local), foram definidos os métodos mais recomendados, em ordem decrescente, para os diferentes trabalhos freqüentemente realizados em fragmentos florestais.

Nenhum método de campo se mostrou viável para checagem dos limites das unidades mais fragmentadas da Reserva ("áreas com indícios de perturbação recente", "áreas sem indícios de perturbação recente" e "clareiras grandes").

Ficou constatado que a utilização de técnicas de sensoriamento remoto para determinação do mosaico florestal, não substitui os trabalhos de campo, apenas permitem um planejamento mais eficiente em termos de tempo e recursos para testar as hipóteses previamente estabelecidas nos trabalhos com vegetação.

Nesse sentido, foi imprescindível o auxílio do GPS de alta precisão para a orientação na floresta e confirmação das unidades ecológicas no campo, inclusive certificando que os locais onde foram realizados os levantamentos pertenciam à unidade ecológica identificada na imagem. 
A utilização das análises de agrupamento e de ordenação mostraram-se eficientes para determinação da similaridade entre as comunidades vegetais estudadas, confirmando a existência das particularidades florísticas e estruturais dessas unidades.

A análise temporal das unidades ecológicas mostrou-se possível de ser aplicada pelos métodos empregados, sendo um potente instrumento de monitoramento ambiental que possibilita o acompanhamento da dinâmica florestal. Isso permitiu detectar o rápido avanço do efeito de borda na Reserva, demonstrando a necessidade de uma estratégia de intervenção em que esse processo seja contido ou revertido.

As alterações temporais das unidades ecológicas permitem monitorar os efeitos dos fatores de perturbação, possibilitando a definição das ações necessárias para o manejo e recuperação desses fragmentos. Do mesmo modo, a localização e quantificação das unidades mais degradadas, podem ajudar a prevenir maiores perturbações como o incêndio e o avanço do efeito de borda nesses fragmentos.

A identificação de 7 unidades ecológicas na Reserva Municipal de Santa Genebra, confirmadas através das análises dos dados florísticos e estruturais, reafirma a necessidade da identificação do mosaico florestal na adequação da escolha de áreas de amostragem nos trabalhos de vegetação. 
ANEXO A 
Lista de espécies e famílias encontradas nos levantamentos florísticos e fitossociológicos das unidades ecológicas da Reserva Municipal de Santa Genebra, Campinas, SP. C.S. = classificação sucessional - $\mathrm{C}=$ Clareiras $-\mathrm{SI}=$ áreas sem indícios de perturbação recente - $\mathrm{CI}=$ áreas com indícios de perturbação recente $-\mathrm{FE}=$ faixa com efeito de borda $-\mathrm{AQ}$ = área queimada $-\mathrm{MD}=$ maciço de Maria-preta $-\mathrm{FB}=$ floresta paludosa - " 0 " = ausência - " 1 " = presença $-\mathrm{P}=$ pioneira $-\mathrm{Si}=$ secundária inicial $-\mathrm{St}=$ secundária tardia e clímaces.

\begin{tabular}{|c|c|c|c|c|c|c|c|c|c|}
\hline FAMÍLIA/ESPÉCIE & C.S. & nome vulgar & $\mathbf{C}$ & $\mathbf{C l}$ & SI & FE & $\mathbf{A Q}$ & MP & FB \\
\hline \multicolumn{10}{|l|}{ ACANTHACEAE } \\
\hline Ruellia brevifolia (Pohl) C.Ezcurra & & & 0 & 0 & 0 & 1 & 0 & 0 & 0 \\
\hline Ruellia sanguinea Griseb. & & & 0 & 0 & 0 & 0 & 0 & 0 & 1 \\
\hline Ruellia puri Mart. ex Nees & & & 0 & 0 & 0 & 0 & 0 & 0 & 1 \\
\hline \multicolumn{10}{|l|}{ ANACARDIACEAE } \\
\hline Astronium graveolens Jacq. & St & guaritá & 1 & 1 & 1 & 1 & 0 & 1 & 1 \\
\hline Tapirira guianensis Aubl. & Si & peito de pombo & 0 & 0 & 1 & 0 & 0 & 0 & 1 \\
\hline $\begin{array}{l}\text { Tapirira cf. obtusa (Benth. ) } \\
\text { J.D.Mitchell }\end{array}$ & & & 0 & 0 & 0 & 0 & 0 & 0 & 1 \\
\hline \multicolumn{10}{|l|}{ ANNONACEAE } \\
\hline Annona cacans Warm. & Sc & araticum-cagão & 0 & 1 & 1 & 0 & 0 & 0 & 0 \\
\hline Duguetia lanceolata A.St.-Hil. & St & pindaíva & 1 & 1 & 1 & 0 & 0 & 0 & 1 \\
\hline Guatteria nigrescens Mart. & St & varejão & 0 & 1 & 1 & 0 & 0 & 1 & 0 \\
\hline Rollinia sylvatica (A.St.-Hil.) Mart. & Si & araticum & 1 & 0 & 1 & 0 & 0 & 1 & 0 \\
\hline Xylopia brasiliensis Spreng. & St & pindaíba & 0 & 0 & 1 & 0 & 0 & 0 & 1 \\
\hline \multicolumn{10}{|l|}{ APOCYNACEAE } \\
\hline $\begin{array}{l}\text { Aspidosperma cylindrocarpum } \\
\text { Müll.Arg. }\end{array}$ & St & peroba poca & 0 & 0 & 1 & 1 & 0 & 0 & 0 \\
\hline Aspidosperma polyneuron Müll.Arg. & St & peroba rosa & 1 & 1 & 1 & 1 & 0 & 1 & 1 \\
\hline Aspidosperma ramiflorum Müll.Arg. & St & $\begin{array}{l}\text { guatambú- } \\
\text { amarelo }\end{array}$ & 1 & 1 & 1 & 0 & 0 & 0 & 0 \\
\hline Forsteronia pilosa (Vell.) Müll.Arg. & & & 0 & 0 & 0 & 1 & 0 & 0 & 0 \\
\hline Prestonia coalita (Vell.) R.E.Woodson & & & 0 & 0 & 0 & 1 & 0 & 0 & 0 \\
\hline Prestonia riedeli (Müll Arg.) Markgraf & & & 0 & 0 & 0 & 1 & 1 & 0 & 0 \\
\hline $\begin{array}{l}\text { Temnadenia omata (Hoehne) } \\
\text { R.E.Woodson }\end{array}$ & & & 0 & 0 & 0 & 1 & 0 & 0 & 0 \\
\hline \multicolumn{10}{|l|}{ ARALIACEAE } \\
\hline $\begin{array}{l}\text { Dendropanax cuneatum (DC.) Decne. } \\
\text { \& Planch. }\end{array}$ & & & 0 & 0 & 1 & 0 & 0 & 0 & 1 \\
\hline $\begin{array}{l}\text { Didymopanax calvum (Cham.) Decne. } \\
\text { \& Planch. }\end{array}$ & Si & mandioqueira & 0 & 0 & 1 & 0 & 0 & 0 & 1 \\
\hline \multicolumn{10}{|l|}{ ARECACEAE } \\
\hline Euterpe edulis Mart. & St & palmito & 0 & 0 & 0 & 0 & 0 & 0 & 1 \\
\hline Geonoma brevispatha Barb. Rodr. & St & & 0 & 0 & 0 & 0 & 0 & 0 & 1 \\
\hline Syagrus oleracea (Mart.) Becc. & St & gueirova & 0 & 0 & 0 & 0 & 1 & 0 & 0 \\
\hline $\begin{array}{l}\text { Syagrus romanzoffiana (Cham.) } \\
\text { Glassman }\end{array}$ & $\mathrm{Si}$ & gerivá & 1 & 1 & 1 & 1 & 0 & 0 & 1 \\
\hline \multicolumn{10}{|l|}{ ARISTOLOCHIACEAE } \\
\hline Aristolochia arcuata Mast. & & & 0 & 0 & 0 & 0 & 1 & 0 & 0 \\
\hline ASTERACEAE & & & & & & & & & \\
\hline
\end{tabular}




\begin{tabular}{|c|c|c|c|c|c|c|c|c|c|}
\hline $\begin{array}{l}\text { Dasyphyllum aff. latifolium (Gardn.) } \\
\text { Cabrera }\end{array}$ & & & 0 & 0 & 0 & 0 & 1 & 0 & 0 \\
\hline $\begin{array}{l}\text { Gochnatia polymorpha (Less.) } \\
\text { Cabrera }\end{array}$ & $\mathrm{P}$ & & 0 & 0 & 1 & 0 & 0 & 0 & 0 \\
\hline Mikania cf. capricornii B.L.Robinson & & & 0 & 0 & 0 & 1 & 0 & 0 & 0 \\
\hline Vernonia diffusa Less. & $\mathrm{P}$ & cambará-açu & 1 & 1 & 1 & 0 & 0 & 0 & 0 \\
\hline Vernonia polyanthes Less. & & & 0 & 0 & 0 & 0 & 1 & 0 & 0 \\
\hline \multicolumn{10}{|l|}{ BIGNONIACEAE } \\
\hline $\begin{array}{l}\text { Adenocalymma bracteatum (Cham.) } \\
\text { DC. }\end{array}$ & & & 0 & 0 & 0 & 0 & 1 & 0 & 0 \\
\hline $\begin{array}{l}\text { Adenocalymma marginatum (Cham.) } \\
\text { DC. }\end{array}$ & & & 0 & 0 & 0 & 0 & 1 & 0 & 0 \\
\hline Arrabidaea af. selloi (Spreng.) Sandw. & & & 0 & 0 & 0 & 0 & 1 & 0 & 0 \\
\hline $\begin{array}{l}\text { Arrabidaea pubescens (L.) } \\
\text { A.H.Gentry }\end{array}$ & & & 0 & 0 & 0 & 0 & 1 & 0 & 0 \\
\hline Arrabidaea triplinervia (Mart.) Baill. & & & 0 & 0 & 0 & 0 & 1 & 0 & 0 \\
\hline $\begin{array}{l}\text { Clytostoma campanulatum (Cham.) } \\
\text { Bur. }\end{array}$ & & & 0 & 0 & 0 & 0 & 1 & 0 & 0 \\
\hline Cuspidaria pterocarpa (Cham.) DC. & & & 0 & 0 & 0 & 0 & 1 & 0 & 0 \\
\hline Fridericia af. speciosa Mart. & & & 0 & 0 & 0 & 1 & 0 & 0 & 0 \\
\hline Jacaranda micrantha Cham. & Si & carobão & 1 & 1 & 1 & 0 & 0 & 0 & 0 \\
\hline Lundia obliqua Sander & & & 0 & 0 & 0 & 1 & 1 & 0 & 0 \\
\hline $\begin{array}{l}\text { Macfadyena unguis-cati (L.) } \\
\text { A.H.Gentry }\end{array}$ & & unha-de-gato & 0 & 0 & 0 & 1 & 0 & 0 & 0 \\
\hline Mansoa difficillis Bur. \& K.Schum. & & & 0 & 0 & 0 & 0 & 1 & 0 & 0 \\
\hline $\begin{array}{l}\text { Pithecoctenium crucigerum (L.) } \\
\text { A.H.Gentry }\end{array}$ & & $\begin{array}{l}\text { pente de } \\
\text { macaco }\end{array}$ & 0 & 0 & 0 & 1 & 1 & 0 & 0 \\
\hline Tabebuia umbellata (Sonder) Sand. & St & $\begin{array}{c}\text { ipê-amarelo-do- } \\
\text { brejo }\end{array}$ & 0 & 0 & 0 & 0 & 0 & 0 & 1 \\
\hline Zeyheria tuberculosa (Vell.) Bur. & St & $\begin{array}{c}\text { ipê-felpudo; } \\
\text { bolsa de pastor }\end{array}$ & 1 & 0 & 0 & 1 & 1 & 0 & 0 \\
\hline \multicolumn{10}{|l|}{ BOMBACACEAE } \\
\hline Chorisia speciosa A.St.-Hil. & $\mathrm{Si}$ & paineira & 1 & 0 & 1 & 0 & 0 & 0 & 0 \\
\hline $\begin{array}{l}\text { Eriotheca cf. pentaphylla (Vell.) A. } \\
\text { Robyns }\end{array}$ & & & 0 & 0 & 0 & 1 & 0 & 0 & 0 \\
\hline $\begin{array}{l}\text { Pseudobombax grandiflorum (Cav.) } \\
\text { A. Robyns }\end{array}$ & $\mathrm{Si}$ & embiruçú & 1 & 1 & 1 & 1 & 0 & 0 & 1 \\
\hline \multicolumn{10}{|l|}{ BORAGINACEAE } \\
\hline Cordia ecalyculata Vell. & $\mathrm{Si}$ & café de bugre & 1 & 0 & 1 & 0 & 0 & 1 & 0 \\
\hline Cordia selowiana Cham. & & & 0 & 0 & 1 & 0 & 0 & 0 & 1 \\
\hline $\begin{array}{l}\text { Cordia trichotoma (Vell.) Arrab. ex } \\
\text { Steud. }\end{array}$ & $\mathrm{Si}$ & louro pardo & 0 & 0 & 1 & 0 & 0 & 0 & 0 \\
\hline Helitropium transalpinum Vell. & & & 0 & 0 & 0 & 1 & 0 & 0 & 0 \\
\hline Patagonula americana L. & $\mathrm{Si}$ & guajuvira & 1 & 0 & 1 & 0 & 0 & 0 & 0 \\
\hline Tournefortia bicolor Sw. & & & 0 & 0 & 0 & 0 & 1 & 0 & 0 \\
\hline \multicolumn{10}{|l|}{ BURSERACEAE } \\
\hline $\begin{array}{l}\text { Protium heptaphyllum (Aubl.) } \\
\text { Marchand }\end{array}$ & & mescla & 0 & 0 & 1 & 0 & 0 & 1 & 1 \\
\hline Protium widgrenii Engl. & $\mathrm{Si}$ & almiscar & 0 & 0 & 1 & 0 & 0 & 0 & 1 \\
\hline
\end{tabular}




\begin{tabular}{|c|c|c|c|c|c|c|c|c|c|}
\hline \multicolumn{10}{|l|}{ CACTACEAE } \\
\hline Pereskia aculeata Mill. & & ora-pro-nobilis & 0 & 0 & 0 & 1 & 0 & 0 & 0 \\
\hline \multicolumn{10}{|l|}{ CAESALPINIACEAE } \\
\hline Copaifera langsdorffii Desf. & St & pau d'óleo & 1 & 0 & 1 & 0 & 0 & 1 & 1 \\
\hline Peltophorum dubium (Spreng.) Taub. & $\mathrm{Si}$ & & 0 & 0 & 0 & 0 & 1 & 0 & 0 \\
\hline Schizolobium parayba (Vell.) Blake & $\mathrm{Si}$ & guapuruvú & 0 & 0 & 0 & 1 & 0 & 0 & 0 \\
\hline \multicolumn{10}{|l|}{ CARICACEAE } \\
\hline Carica quercifolia (A.St.-Hil.) Solms & & & 0 & 0 & 0 & 0 & 0 & 1 & 0 \\
\hline Jacaratia spinosa (Aubl.) A. DC & $\mathrm{P}$ & jaracatiá & 1 & 1 & 1 & 1 & 1 & 0 & 0 \\
\hline \multicolumn{10}{|l|}{ CECROPIACEAE } \\
\hline Cecropia glazioui Snethlage & $\mathrm{P}$ & embaúva & 1 & 0 & 1 & 0 & 0 & 0 & 0 \\
\hline Cecropia hololeuca Miq. & $\mathrm{P}$ & $\begin{array}{l}\text { embaúva- } \\
\text { vermelha }\end{array}$ & 1 & 0 & 1 & 1 & 0 & 0 & 0 \\
\hline Cecropia pachystachya Tréc. & $\mathrm{P}$ & embaúva-branca & 1 & 0 & 1 & 0 & 0 & 0 & 1 \\
\hline \multicolumn{10}{|l|}{ CELASTRACEAE } \\
\hline Maytenus ilicifolia Mart. ex Reissek & St & espinheira-santa & 1 & 0 & 0 & 0 & 0 & 0 & 0 \\
\hline Maytenus robusta Reissek & St & $\begin{array}{l}\text { cafezinho-do- } \\
\text { mato }\end{array}$ & 0 & 0 & 1 & 0 & 0 & 0 & 0 \\
\hline \multicolumn{10}{|l|}{ CHRYSOBALANACEAE } \\
\hline Hirtella hebeclada Moric. & $\mathrm{Si}$ & simbiúva & 0 & 0 & 1 & 0 & 0 & 0 & 0 \\
\hline \multicolumn{10}{|l|}{ CLUSIACEAE } \\
\hline Calophyllum brasiliense Cambess. & Sc & guanandi & 0 & 0 & 1 & 0 & 0 & 0 & 0 \\
\hline \multicolumn{10}{|l|}{ COMBRETACEAE } \\
\hline Terminalia triflora (Griseb.) Lillo & $\mathrm{Si}$ & & 0 & 0 & 1 & 0 & 0 & 0 & 0 \\
\hline \multicolumn{10}{|l|}{ COMMELINACEAE } \\
\hline Commelina obliqua Vahl & & & 0 & 0 & 0 & 1 & 0 & 0 & 1 \\
\hline \multicolumn{10}{|l|}{ CONVOLVULACEAE } \\
\hline Ipomoea bonariensis Hook & & & 0 & 0 & 0 & 1 & 0 & 0 & 0 \\
\hline Ipomoea carnea Jacq. & & & 0 & 0 & 0 & 1 & 0 & 0 & 0 \\
\hline \multicolumn{10}{|l|}{ Ipomoea hederifolia L. } \\
\hline Ipomoea saopaulista O'Donell & & & 0 & 0 & 0 & 0 & 1 & 0 & 0 \\
\hline $\begin{array}{l}\text { Merremia macrocalyx (Ruiz \& Pav.) } \\
\text { O'Donell }\end{array}$ & & & 0 & 0 & 0 & 1 & 1 & 0 & 0 \\
\hline \multicolumn{10}{|l|}{ CUCURBITACEAE } \\
\hline Wilbrandia cf. Hibiscoides Manso & & & 0 & 0 & 0 & 1 & 0 & 0 & 0 \\
\hline \multicolumn{10}{|l|}{ CUNONIACEAE } \\
\hline Lamanonia ternata Vell. & & & 0 & 0 & 0 & 0 & 0 & 1 & 0 \\
\hline \multicolumn{10}{|l|}{ DILLENIACEAE } \\
\hline Davilla rugosa Poir. & & & 0 & 0 & 0 & 1 & 0 & 0 & 0 \\
\hline \multicolumn{10}{|l|}{ DIOSCOREACEAE } \\
\hline Dioscorea altissima Lam. & & & 0 & 0 & 0 & 0 & 1 & 0 & 0 \\
\hline Dioscorea dodecaneura Vell. & & & 0 & 0 & 0 & 1 & 0 & 0 & 0 \\
\hline Dioscorea multiflora Mart. ex Griseb. & & & 0 & 0 & 0 & 0 & 1 & 0 & 0 \\
\hline \multicolumn{10}{|l|}{ EBENACEAE } \\
\hline Diospyros inconstans Jacq. & St & & 1 & 0 & 0 & 0 & 0 & 0 & 0 \\
\hline \multicolumn{10}{|l|}{ ELAEOCARPACEAE } \\
\hline Sloanea monosperma Vell. & St & & 0 & 0 & 1 & 0 & 0 & 1 & 1 \\
\hline \multicolumn{10}{|l|}{ EUPHORBIACEAE } \\
\hline Actinostemon klotschii (Müll.Arg.) Pax & $\mathrm{Si}$ & branquilho & 1 & 0 & 1 & 0 & 0 & 1 & 0 \\
\hline
\end{tabular}




\begin{tabular}{|c|c|c|c|c|c|c|c|c|c|}
\hline Alchomea glandulosa Poepp. \& Endl. & $P$ & tapiá & 1 & 1 & 1 & 0 & 0 & 1 & 1 \\
\hline $\begin{array}{l}\text { Alchomea triplinervia (Spreng.) } \\
\text { Müll.Arg. }\end{array}$ & $\mathrm{P}$ & tapiá & 0 & 0 & 0 & 1 & 0 & 0 & 1 \\
\hline Croton floribundus Spreng. & $\mathrm{P}$ & capixingui & 1 & 1 & 1 & 1 & 1 & 0 & 1 \\
\hline Croton priscus Croizat & $\mathrm{P}$ & paú-sangue & 1 & 1 & 1 & 0 & 1 & 0 & 1 \\
\hline Dalechampia ficifolia Dam. & & & 0 & 0 & 0 & 0 & 1 & 0 & 0 \\
\hline Maprounea guianensis A.St.-Hil. & St & & 0 & 0 & 1 & 0 & 0 & 0 & 0 \\
\hline $\begin{array}{l}\text { Pachystroma longifolium (Nees) } \\
\text { I.M.Johnston }\end{array}$ & St & canxim & 1 & 0 & 1 & 0 & 1 & 1 & 0 \\
\hline Pera obovata Baill. & $\mathrm{Si}$ & chapéu-de-couro & 0 & 0 & 0 & 0 & 0 & 0 & 1 \\
\hline Savia dyctiocarpa Kuhlm. & St & guaraiúva & 1 & 0 & 1 & 0 & 0 & 1 & 1 \\
\hline $\begin{array}{l}\text { Sebastiania commersoniana Pax \& } \\
\text { K.Hoffm. }\end{array}$ & St & branquilho & 0 & 1 & 1 & 0 & 0 & 0 & 1 \\
\hline $\begin{array}{l}\text { Sebastiania klotschiana Pax \& } \\
\text { K.Hoffm. }\end{array}$ & St & branquilho & 1 & 0 & 0 & 0 & 0 & 0 & 0 \\
\hline $\begin{array}{l}\text { Sebastiania edwalliana Pax \& } \\
\text { K.Hoffm. }\end{array}$ & St & branquilho & 0 & 0 & 1 & 0 & 0 & 0 & 0 \\
\hline Sebastiania serrata (Baill.) Müll.Arg. & St & branquilho & 0 & 0 & 0 & 0 & 0 & 1 & 1 \\
\hline Tetrorchidium rubrinervum Müll.Arg. & $\mathrm{P}$ & & 0 & 0 & 1 & 0 & 0 & 0 & 0 \\
\hline \multicolumn{10}{|l|}{ FABACEAE } \\
\hline Andira fraxinifolia Benth. & St & & 0 & 0 & 0 & 0 & 0 & 1 & 0 \\
\hline Andira cf. inermis H.B.K. & St & & 0 & 0 & 0 & 0 & 0 & 0 & 1 \\
\hline $\begin{array}{l}\text { Centrolobium tomentosum Guill. ex } \\
\text { Benth. }\end{array}$ & $\mathrm{Si}$ & araribá & 1 & 1 & 1 & 1 & 1 & 1 & 0 \\
\hline $\begin{array}{l}\text { Centrosema sagittatum (Kunth) } \\
\text { Brandeg. }\end{array}$ & & & 0 & 0 & 0 & 0 & 1 & 0 & 0 \\
\hline Dalbergia frutescens (Vell.) Britton & & & 0 & 0 & 0 & 1 & 0 & 0 & 0 \\
\hline Desmodium uncinatum (Jacq.) DC. & & & 0 & 0 & 0 & 0 & 1 & 0 & 0 \\
\hline Dioclea cf. rufescens Benth. & & & 0 & 0 & 0 & 1 & 0 & 0 & 0 \\
\hline Holocalyx balansae Micheli & St & $\begin{array}{l}\text { alecrim de } \\
\text { campinas }\end{array}$ & 1 & 1 & 1 & 1 & 1 & 1 & 0 \\
\hline Lonchocarpus muehlbergianus Hassl. & $\mathrm{Si}$ & embira-de-sapo & 0 & 0 & 0 & 0 & 1 & 0 & 0 \\
\hline $\begin{array}{l}\text { Lonchocarpus guillemenianus (Tul.) } \\
\text { Malme }\end{array}$ & $\mathrm{Si}$ & embira de sapo & 1 & 1 & 1 & 0 & 0 & 0 & 0 \\
\hline Luetzelburguia guaissara Toledo & $\mathrm{Si}$ & guaiçara & 0 & 0 & 1 & 0 & 0 & 1 & 0 \\
\hline Machaerium aculeatum Raddi & $\mathrm{Si}$ & pico de pato & 0 & 0 & 1 & 0 & 0 & 0 & 1 \\
\hline Machaerium brasiliense Vogel & St & jacarandá & 0 & 0 & 1 & 0 & 0 & 0 & 0 \\
\hline Machaerium nictitans (Vell.) Benth. & $\mathrm{Si}$ & jacarandá ferro & 0 & 0 & 1 & 0 & 0 & 0 & 0 \\
\hline Machaerium stipitatum (DC.) Vogel & $\mathrm{Si}$ & sapuvinha & 1 & 1 & 1 & 1 & 1 & 0 & 0 \\
\hline Machaerium vestitum Vogel & St & & 0 & 1 & 1 & 0 & 0 & 1 & 0 \\
\hline Machaerium villosum Vogel & St & $\begin{array}{l}\text { jacarandá } \\
\text { paulista }\end{array}$ & 1 & 0 & 1 & 0 & 0 & 0 & 0 \\
\hline Myroxylon peruiferum L.f. & St & cabreúva & 0 & 0 & 1 & 0 & 0 & 0 & 1 \\
\hline Ormosia arborea (Vell.) Harms & St & olho-de-cabra & 0 & 0 & 0 & 1 & 0 & 0 & 0 \\
\hline Platypodium elegans Vogel & Si & $\begin{array}{l}\text { Jacarandá-do- } \\
\text { campo }\end{array}$ & 0 & 0 & 0 & 1 & 0 & 0 & 0 \\
\hline Rhynchosia phaseoloides (Sw.) DC. & & & 0 & 0 & 0 & 0 & 1 & 0 & 0 \\
\hline Sweetia fruticosa Spreng. & St & $\begin{array}{l}\text { sucupira } \\
\text { amarela }\end{array}$ & 1 & 0 & 1 & 0 & 0 & 0 & 0 \\
\hline
\end{tabular}




\begin{tabular}{|c|c|c|c|c|c|c|c|c|c|}
\hline \multicolumn{10}{|l|}{ FLACOURTIACEAE } \\
\hline Casearia decandra Jacq. & St & pau espeto & 0 & 0 & 1 & 0 & 0 & 0 & 0 \\
\hline Casearia gossypiospermum Briquet & St & pau espeto & 1 & 0 & 1 & 0 & 0 & 0 & 0 \\
\hline Casearia obliqua Spreng. & $\mathrm{Si}$ & guaçatonga & 0 & 0 & 1 & 0 & 0 & 0 & 0 \\
\hline Casearia sylvestris Sw. & $\mathrm{P}$ & guaçatonga & 1 & 0 & 1 & 1 & 1 & 0 & 0 \\
\hline Prockia crucis P.Browne ex L. & St & & 1 & 1 & 1 & 0 & 0 & 0 & 0 \\
\hline \multicolumn{10}{|l|}{ ICACINACEAE } \\
\hline Citronella paniculata (Mart.) Howard & Sc & citronela & 0 & 1 & 1 & 0 & 0 & 1 & 0 \\
\hline \multicolumn{10}{|l|}{ LACISTEMACEAE } \\
\hline Lacistema hasslerianum Chodat & & & 0 & 0 & 0 & 0 & 0 & 1 & 1 \\
\hline \multicolumn{10}{|l|}{ LAURACEAE } \\
\hline Cryptocarya aschersoniana Mez & St & canela batalha & 0 & 0 & 1 & 0 & 0 & 1 & 0 \\
\hline Cryptocarya moschata Nees \& Mart. & St & canela batalha & 0 & 0 & 1 & 0 & 0 & 0 & 0 \\
\hline $\begin{array}{l}\text { Endlicheria paniculata (Spreng.) } \\
\text { J.F.Macbr. }\end{array}$ & St & canela do brejo & 0 & 1 & 1 & 0 & 0 & 0 & 1 \\
\hline $\begin{array}{l}\text { Nectandra megapotanica (Spreng.) } \\
\text { Mez }\end{array}$ & Si & canelinha & 1 & 1 & 1 & 1 & 0 & 1 & 1 \\
\hline Nectandra oppositifolia Nees & St & canelão & 0 & 0 & 1 & 0 & 0 & 0 & 0 \\
\hline Ocotea beulahiae Baitello & Sc & canela & 1 & 1 & 1 & 1 & 0 & 1 & 1 \\
\hline Ocotea corymbosa (Meisn.) Mez & $\mathrm{Si}$ & canela parda & 0 & 1 & 1 & 0 & 0 & 1 & 0 \\
\hline Ocotea odorifera (Vell.) Rohwer & & & 0 & 0 & 1 & 0 & 0 & 1 & 1 \\
\hline Ocotea puberula (Rich.) Nees & Si & guaiacá & 0 & 1 & 1 & 0 & 0 & 0 & 0 \\
\hline Ocotea pulchella (Nees) Mez & $\mathrm{Si}$ & canela lageana & 0 & 0 & 1 & 0 & 0 & 0 & 0 \\
\hline Lauraceae1 & & & 0 & 0 & 0 & 0 & 0 & 0 & 1 \\
\hline \multicolumn{10}{|l|}{ LECYTHIDACEAE } \\
\hline $\begin{array}{l}\text { Cariniana estrellensis (Raddi) } \\
\text { O.Kuntze }\end{array}$ & St & jequitibá branco & 1 & 1 & 1 & 0 & 0 & 1 & 1 \\
\hline Cariniana legalis (Mart.) O.Kuntze & St & $\begin{array}{l}\text { jequitibá } \\
\text { vermelho }\end{array}$ & 1 & 1 & 1 & 1 & 1 & 0 & 0 \\
\hline \multicolumn{10}{|l|}{ LYTHRACEAE } \\
\hline Lafoensia pacari A.St.-Hil. & $\mathrm{Si}$ & dedaleiro & 0 & 0 & 1 & 0 & 0 & 0 & 0 \\
\hline \multicolumn{10}{|l|}{ MAGNOLIACEAE } \\
\hline Talauma ovata A.St.-Hil. & St & pinha do brejo & 0 & 0 & 0 & 0 & 0 & 0 & 1 \\
\hline \multicolumn{10}{|l|}{ MALPIGHIACEAE } \\
\hline \begin{tabular}{|l|} 
Banisteriopsis adenopoda (A.Juss.) \\
B.Gates \\
\end{tabular} & & & 0 & 0 & 0 & 0 & 1 & 0 & 0 \\
\hline $\begin{array}{l}\text { Banisteriopsis cf. laevifolia (A.Juss.) } \\
\text { B.Gates }\end{array}$ & & & 0 & 0 & 0 & 1 & 0 & 0 & 0 \\
\hline $\begin{array}{l}\text { Banisteriopsis cf. muricata (Cav.) } \\
\text { Cuatrec. }\end{array}$ & & & 0 & 0 & 0 & 1 & 0 & 0 & 0 \\
\hline Dicella bacteosa Griseb. & & & 0 & 0 & 0 & 0 & 1 & 0 & 0 \\
\hline Stigmaphyllon lalandianum A.Juss. & & & 0 & 0 & 0 & 1 & 0 & 0 & 0 \\
\hline Tetrapteris mucronata Cav. & & & 0 & 0 & 0 & 1 & 0 & 0 & 0 \\
\hline \multicolumn{10}{|l|}{ MALVACEAE } \\
\hline $\begin{array}{l}\text { Abutilon bedfordianum A.St.-Hil. \& } \\
\text { Naud. }\end{array}$ & $P$ & & 1 & 0 & 0 & 0 & 0 & 0 & 0 \\
\hline Abutilon peltatum K.Schum. & & & 0 & 0 & 0 & 1 & 1 & 0 & 0 \\
\hline Pavonia sepium A.St.-Hil. & $\mathrm{P}$ & & 1 & 0 & 0 & 0 & 0 & 0 & 0 \\
\hline Sida cordifolia L. & & & 0 & 0 & 0 & 0 & 1 & 0 & 0 \\
\hline
\end{tabular}




\begin{tabular}{|c|c|c|c|c|c|c|c|c|c|}
\hline \multicolumn{10}{|l|}{ MELASTOMATACEAE } \\
\hline Leandra alteminervia Cogn. & & & 0 & 0 & 0 & 0 & 0 & 0 & 1 \\
\hline Leandra australis (Cham.) Cogn. & & & 0 & 0 & 0 & 0 & 0 & 0 & 1 \\
\hline Miconia chamissois Naud. & & & 0 & 0 & 0 & 0 & 0 & 0 & 1 \\
\hline Miconia discolor DC. & & & 0 & 0 & 0 & 0 & 0 & 1 & 1 \\
\hline Miconia hymenonervia (Raddi) Cogn. & & & 0 & 0 & 1 & 0 & 0 & 0 & 1 \\
\hline Miconia inaequidens Naud. & $P$ & jacatirão & 1 & 0 & 1 & 0 & 0 & 0 & 0 \\
\hline Miconia ligustroides (DC.) Naudin & & & 0 & 0 & 0 & 0 & 0 & 0 & 1 \\
\hline Miconia sp1 & & & 0 & 0 & 0 & 0 & 0 & 0 & 1 \\
\hline Miconia sp2 & & & 0 & 0 & 0 & 0 & 0 & 0 & 1 \\
\hline Miconia sp3 & & & 0 & 0 & 0 & 0 & 0 & 0 & 1 \\
\hline Ossaea bachystachya Triana & & & 0 & 0 & 0 & 0 & 0 & 0 & 1 \\
\hline \multicolumn{10}{|l|}{ MELIACEAE } \\
\hline Cabralea canjerana (Vell.) Mart. & Si & canjerana & 0 & 1 & 1 & 1 & 0 & 1 & 1 \\
\hline Cedrela fissilis Vell. & St & cedro & 1 & 1 & 1 & 1 & 1 & 0 & 1 \\
\hline Guarea guidonea (L.) Sleumer & St & marinheiro & 0 & 0 & 1 & 0 & 0 & 0 & 0 \\
\hline Guarea macrophylla Vahl & & & 0 & 0 & 0 & 0 & 0 & 0 & 1 \\
\hline Guarea kunthiana A.Juss. & St & marinheiro & 0 & 1 & 1 & 0 & 1 & 0 & 1 \\
\hline Trichilia casaretti C.DC. & & & 0 & 0 & 0 & 0 & 0 & 1 & 1 \\
\hline Trichilia catigua A.Juss. & St & catiguá & 1 & 1 & 1 & 0 & 0 & 1 & 1 \\
\hline Trichilia clausseni C.DC. & Si & $\begin{array}{c}\text { catigua } \\
\text { vermelho }\end{array}$ & 1 & 1 & 1 & 0 & 1 & 1 & 1 \\
\hline Trichilia elegans A.Juss. & St & $\begin{array}{l}\text { catigua de folha } \\
\text { miúda }\end{array}$ & 1 & 0 & 1 & 0 & 0 & 0 & 0 \\
\hline Trichilia hirta L. & St & catiguá & 0 & 0 & 1 & 0 & 0 & 0 & 0 \\
\hline Trichilia pallida Sw. & St & catiguá amarelo & 1 & 1 & 1 & 0 & 1 & 1 & 1 \\
\hline \multicolumn{10}{|l|}{ MENISPERMACEAE } \\
\hline Cissampelos andromorpha DC. & & & 0 & 0 & 0 & 1 & 0 & 0 & 0 \\
\hline \multicolumn{10}{|l|}{ MIMOSACEAE } \\
\hline Acacia polyphylla DC. & $P$ & angico-branco & 1 & 0 & 1 & 1 & 1 & 1 & 0 \\
\hline Acacia recurva Benth. & & & 0 & 0 & 0 & 0 & 1 & 0 & 0 \\
\hline Acacia paniculata Willd. & $\mathrm{P}$ & & 1 & 0 & 0 & 0 & 0 & 0 & 0 \\
\hline Albizia polycephalla (Benth.) Killip & $\mathrm{Si}$ & & 0 & 1 & 1 & 0 & 0 & 0 & 0 \\
\hline $\begin{array}{l}\text { Enterolobium contortisiliquum (Vell.) } \\
\text { Morong }\end{array}$ & Si & tamboril & 0 & 0 & 0 & 0 & 1 & 0 & 0 \\
\hline Inga striata Benth. & Sc & ingá & 0 & 1 & 1 & 0 & 0 & 0 & 1 \\
\hline Inga luschnathiana Benth. & Si & ingá & 1 & 1 & 1 & 0 & 0 & 0 & 0 \\
\hline Inga marginata Willd. & & & 0 & 0 & 0 & 0 & 1 & 1 & 1 \\
\hline Inga uruguensis Hook. \& Arn. & $\mathrm{Si}$ & ingá & 0 & 0 & 1 & 0 & 0 & 0 & 0 \\
\hline $\begin{array}{l}\text { Piptadenia gonoacantha (Mart.) } \\
\text { J.F.Macbr. }\end{array}$ & $\mathrm{Si}$ & pau-jacaré & 1 & 1 & 1 & 1 & 1 & 0 & 1 \\
\hline \multicolumn{10}{|l|}{ MONIMIACEAE } \\
\hline Mollinedia clavigera Tul. & & & 0 & 0 & 0 & 0 & 0 & 1 & 0 \\
\hline Mollinedia widgrenii A.DC. & St & & 0 & 1 & 1 & 0 & 0 & 1 & 1 \\
\hline Siparuna guianensis Aubl. & $\mathrm{Si}$ & & 0 & 0 & 1 & 0 & 0 & 0 & 0 \\
\hline \multicolumn{10}{|l|}{ MORACEAE } \\
\hline Dorstenia hirta Desv. & St & & 0 & 0 & 0 & 0 & 0 & 0 & 1 \\
\hline Ficus glaba Vell. & $\mathrm{Si}$ & figueira & 1 & 0 & 1 & 0 & 0 & 0 & 0 \\
\hline Maclura tinctoria (L.) D.Don ex & $\mathrm{Si}$ & taiúva & 0 & 1 & 1 & 0 & 0 & 0 & 0 \\
\hline
\end{tabular}




\begin{tabular}{|c|c|c|c|c|c|c|c|c|c|}
\hline Steud. & & & & & & & & & \\
\hline $\begin{array}{l}\text { Sorocea bonplandii (Baill.) } \\
\text { W.C.Burger, Lanj. \& Wess.Boer }\end{array}$ & & & 0 & 0 & 0 & 0 & 0 & 1 & 1 \\
\hline \multicolumn{10}{|l|}{ MYRSINACEAE } \\
\hline Ardisia glaucifolia Urb. & & & 0 & 0 & 0 & 0 & 0 & 1 & 1 \\
\hline Ardisia latipes Mart. & St. & & 1 & 0 & 0 & 0 & 0 & 0 & 0 \\
\hline Cybianthus cuneifolius Mart. & Sc & & 1 & 0 & 0 & 0 & 0 & 0 & 0 \\
\hline Rapanea guianensis Aubl. & & capororóca & 0 & 0 & 0 & 0 & 1 & 0 & 0 \\
\hline Rapanea intermedia Mez & & & 0 & 0 & 0 & 0 & 0 & 0 & 1 \\
\hline Rapanea umbellata (Mart.) Mez & Si & capororóca & 1 & 1 & 1 & 0 & 0 & 0 & 0 \\
\hline \multicolumn{10}{|l|}{ MYRTACEAE } \\
\hline $\begin{array}{l}\text { Calyptranthes clusiaefolia (Miq.) } \\
\text { O.Berg }\end{array}$ & & & 0 & 0 & 0 & 0 & 0 & 0 & 1 \\
\hline Calyptranthes concinna DC. & & & 0 & 0 & 1 & 0 & 0 & 1 & 0 \\
\hline Calyptranthes sp1 & & & 0 & 0 & 0 & 0 & 0 & 1 & 1 \\
\hline $\begin{array}{l}\text { Campomanesia guavirova (DC.) } \\
\text { Kiaersk. }\end{array}$ & St & sete capotes & 0 & 1 & 1 & 0 & 0 & 0 & 0 \\
\hline $\begin{array}{l}\text { Campomanesia mascalantha } \\
\text { (O.Berg) Kiaersk. }\end{array}$ & St & sete capotes & 0 & 0 & 1 & 0 & 0 & 0 & 0 \\
\hline Campomanesia sp1 & & & 0 & 0 & 0 & 0 & 0 & 1 & 0 \\
\hline Eugenia aff. excelsa O.Berg & & & 0 & 0 & 1 & 0 & 0 & 0 & 0 \\
\hline Eugenia glazioviana Kiaersk. & St & & 0 & 0 & 1 & 0 & 0 & 0 & 0 \\
\hline Eugenia cf. cambucarana Kiaersk. & & & 0 & 0 & 0 & 0 & 0 & 1 & 0 \\
\hline Eugenia florida DC. & & & 0 & 0 & 0 & 0 & 1 & 1 & 1 \\
\hline Eugenia ligustrina Willd. & St. & & 1 & 0 & 1 & 0 & 0 & 1 & 1 \\
\hline Eugenia pyriformis Cambess. & & & 0 & 0 & 1 & 0 & 0 & 1 & 0 \\
\hline Eugenia sp1 & Sc & & 0 & 0 & 0 & 0 & 0 & 1 & 0 \\
\hline Eugenia sp2 & & & 0 & 0 & 1 & 0 & 0 & 0 & 0 \\
\hline Eugenia aff. ligustrina Willd. & & & 0 & 0 & 0 & 0 & 0 & 1 & 0 \\
\hline Eugenia stictosepala Kiaersk. & & & 0 & 0 & 0 & 0 & 0 & 0 & 1 \\
\hline Eugenia verrucosa D.Legrand. & St & & 1 & 0 & 1 & 0 & 0 & 0 & 0 \\
\hline $\begin{array}{l}\text { Gomidesia affinis (Cambess.) } \\
\text { D.Legrand }\end{array}$ & St & & 0 & 0 & 1 & 0 & 0 & 0 & 0 \\
\hline $\begin{array}{l}\text { Myrceugenia campestris (DC.) } \\
\text { D.Legrand \& Kausel }\end{array}$ & $\mathrm{Sc}$ & cambuí & 0 & 0 & 1 & 0 & 0 & 0 & 0 \\
\hline Myrcia ramulosa DC. & & & 0 & 0 & 0 & 0 & 0 & 1 & 1 \\
\hline Myrcia cf. rostrata DC. & $\mathrm{P}$ & lanceira & 1 & 0 & 1 & 0 & 0 & 1 & 1 \\
\hline Myrcia sp1 & & & 0 & 0 & 0 & 0 & 0 & 1 & 0 \\
\hline Myrcia sp2 & & & 0 & 0 & 0 & 0 & 0 & 1 & 0 \\
\hline $\begin{array}{l}\text { Myrciaria floribunda (West ex Willd.) } \\
\text { O.Berg }\end{array}$ & St & & 1 & 1 & 1 & 0 & 0 & 0 & 0 \\
\hline Myrciaria sp1 & & & 0 & 0 & 0 & 0 & 0 & 1 & 1 \\
\hline Myrciaria sp2 & & & 0 & 0 & 0 & 0 & 0 & 1 & 0 \\
\hline Myrciaria sp3 & & & 1 & 0 & 0 & 0 & 0 & 0 & 0 \\
\hline Myrtaceae sp1 & Sc & & 0 & 0 & 0 & 0 & 0 & 0 & 1 \\
\hline Myrtaceae sp2 & Sc & & 0 & 0 & 0 & 0 & 0 & 0 & 1 \\
\hline Myrtaceae sp3 & Sc & & 0 & 0 & 0 & 0 & 0 & 0 & 1 \\
\hline Myrtaceae sp4 & & & 0 & 0 & 0 & 0 & 0 & 0 & 1 \\
\hline Myrtaceae sp5 & & & 0 & 0 & 1 & 0 & 0 & 0 & 0 \\
\hline
\end{tabular}




\begin{tabular}{|c|c|c|c|c|c|c|c|c|c|}
\hline Myrtaceae sp6 & & & 0 & 0 & 1 & 0 & 0 & 0 & 0 \\
\hline Myrtaceae sp7 & & & 0 & 0 & 1 & 0 & 0 & 0 & 0 \\
\hline Psidium sp & Sc & & 0 & 1 & 0 & 0 & 0 & 0 & 0 \\
\hline Siphoneugena densiflora O.Berg. & Si & & 0 & 0 & 1 & 0 & 0 & 0 & 0 \\
\hline \multicolumn{10}{|l|}{ NYCTAGINACEAE } \\
\hline Guapira opposita (Vell.) Reitz & Si & maria mole & 0 & 1 & 1 & 1 & 0 & 1 & 1 \\
\hline Pisonia ambigua Heimerl & St & & 1 & 1 & 1 & 0 & 1 & 0 & 0 \\
\hline \multicolumn{10}{|l|}{ OPILIACEAE } \\
\hline Agonandra englerii Hoehne & St & & 0 & 0 & 1 & 0 & 0 & 1 & 0 \\
\hline \multicolumn{10}{|l|}{ OXALIDACEAE } \\
\hline Oxalis rhombeo-ovata A.St.-Hil. & Sc & & 1 & 0 & 0 & 0 & 0 & 0 & 0 \\
\hline \multicolumn{10}{|l|}{ PASSIFLORACEAE } \\
\hline Passiflora alata Ait. & & maracujá & 0 & 0 & 0 & 0 & 1 & 0 & 0 \\
\hline Passiflora capsularis L. & & & 0 & 0 & 0 & 1 & 0 & 0 & 0 \\
\hline Passiflora aff.sidaefolia M.Roem. & & & 0 & 0 & 0 & 0 & 1 & 0 & 0 \\
\hline Passiflora cf. cincinata Mast. & & & 0 & 0 & 0 & 1 & 0 & 0 & 0 \\
\hline Passiflora sp1 & & & 0 & 0 & 0 & 0 & 1 & 0 & 0 \\
\hline \multicolumn{10}{|l|}{ PHYTOLACCACEAE } \\
\hline Galesia integrifolia (Spreng.) Harms & St & pau d'alho & 0 & 1 & 1 & 0 & 0 & 0 & 0 \\
\hline Seguieria floribunda Benth. & Si & limão bravo & 1 & 0 & 1 & 0 & 0 & 0 & 0 \\
\hline Seguieria langsdorfii Moq. & Si & limão bravo & 0 & 1 & 1 & 0 & 0 & 0 & 0 \\
\hline \multicolumn{10}{|l|}{ PIPERACEAE } \\
\hline Ottonia propinqua Kunth & & & 1 & 0 & 0 & 1 & 0 & 0 & 0 \\
\hline Piper amalago L. & & & 1 & 0 & 1 & 1 & 1 & 1 & 1 \\
\hline Piper amplum Kunth. & & & 1 & 0 & 0 & 0 & 0 & 0 & 1 \\
\hline Piper arboreum Aubl. & & & 0 & 0 & 0 & 0 & 0 & 0 & 1 \\
\hline Piper gaudichaudianum Kunth. & $P$ & & 1 & 0 & 1 & 0 & 0 & 0 & 0 \\
\hline Piper marginatum Jacq. & & & 0 & 0 & 0 & 0 & 0 & 0 & 1 \\
\hline Piper molicomum Kunth. & & & 0 & 0 & 0 & 0 & 1 & 0 & 0 \\
\hline \multicolumn{10}{|l|}{ POACEAE } \\
\hline Merostachys riedeliana Rupr. ex Doell & $P$ & Bambú & 1 & 1 & 1 & 1 & 1 & 1 & 1 \\
\hline \multicolumn{10}{|l|}{ POLYGALACEAE } \\
\hline Polygala klotzschii Chodat & & & 1 & 0 & 0 & 0 & 0 & 1 & 1 \\
\hline Securidaca sp1 & & & 0 & 0 & 0 & 1 & 0 & 0 & 0 \\
\hline \multicolumn{10}{|l|}{ RHAMNACEAE } \\
\hline Colubrina glandulosa Perkins & Si & $\begin{array}{l}\text { saguarají } \\
\text { vermelho }\end{array}$ & 1 & 0 & 1 & 0 & 1 & 0 & 0 \\
\hline Gouania virgata Reissek & & & 0 & 0 & 0 & 1 & 1 & 0 & 0 \\
\hline Rhamnidium elaeocarpum Reissek & Si & $\begin{array}{c}\text { saguarají } \\
\text { amarelo }\end{array}$ & 1 & 0 & 1 & 0 & 0 & 1 & 0 \\
\hline \multicolumn{10}{|l|}{ ROSACEAE } \\
\hline Prunus myrtifolia (L.) Urb. & & $\begin{array}{c}\text { pessegueiro- } \\
\text { bravo }\end{array}$ & 0 & 0 & 0 & 1 & 0 & 0 & 1 \\
\hline \multicolumn{10}{|l|}{ RUBIACEAE } \\
\hline Amaioua guianensis Aubl. & Si & $\begin{array}{c}\text { marmelada } \\
\text { brava }\end{array}$ & 0 & 0 & 1 & 0 & 0 & 1 & 0 \\
\hline Chomelia obtusa Cham. \& Schltdl. & St & & 1 & 0 & 1 & 0 & 0 & 0 & 0 \\
\hline Chomelia pedunculosa Benth. & & & 0 & 0 & 0 & 1 & 1 & 0 & 0 \\
\hline Chomelia sericea Müll.Arg. & St & & 0 & 1 & 1 & 0 & 0 & 0 & 0 \\
\hline
\end{tabular}




\begin{tabular}{|c|c|c|c|c|c|c|c|c|c|}
\hline Coffea arabica L. & Sc & café & 1 & 0 & 1 & 0 & 0 & 1 & 1 \\
\hline $\begin{array}{l}\text { Coussarea contracta (Walp.) Benth. } \\
\text { \& Hook. ex Müll.Arg. }\end{array}$ & St & & 1 & 0 & 1 & 0 & 0 & 1 & 0 \\
\hline Coutarea hexandra (Jacq.) K.Schum. & Si & & 0 & 0 & 1 & 0 & 1 & 1 & 0 \\
\hline $\begin{array}{l}\text { Guettarda vibumioides Cham. \& } \\
\text { Schltdl. }\end{array}$ & St & & 1 & 0 & 0 & 0 & 0 & 0 & 0 \\
\hline Ixora gardneriana Benth. & St & & 0 & 0 & 1 & 0 & 0 & 0 & 1 \\
\hline Ixora venulosa Benth. & St & & 0 & 0 & 1 & 0 & 0 & 1 & 1 \\
\hline Palicourea marcgravii A.St.-Hil. & St & & 1 & 0 & 0 & 0 & 0 & 0 & 0 \\
\hline Psychotria brachyceras Müll.Arg. & & & 0 & 0 & 0 & 0 & 0 & 1 & 0 \\
\hline Psychotria carthagenensis Jacq. & St & & 1 & 0 & 0 & 0 & 0 & 0 & 1 \\
\hline Psychotria hastisepala Müll.Arg. & St & & 1 & 0 & 0 & 0 & 0 & 0 & 0 \\
\hline $\begin{array}{l}\text { Psychotria hoffmanseggiana (Roem. } \\
\text { \& Schult.) Müll.Arg. }\end{array}$ & & & 0 & 0 & 0 & 0 & 0 & 1 & 1 \\
\hline Psychotria leiocarpa Cham. \& Schltdl. & St & & 1 & 0 & 0 & 0 & 0 & 0 & 0 \\
\hline Psychotria mapourioides DC. & & & 0 & 0 & 0 & 0 & 0 & 1 & 1 \\
\hline $\begin{array}{l}\text { Psychotria nuda (Cham. \& Schltdl.) } \\
\text { Wawra }\end{array}$ & & & 0 & 0 & 0 & 0 & 0 & 1 & 1 \\
\hline Psychotria sessilis (Vell.) Müll.Arg. & & & 0 & 0 & 1 & 0 & 0 & 1 & 1 \\
\hline Psychotria brachybotrya Müll.Arg. & & & 0 & 0 & 0 & 0 & 0 & 1 & 1 \\
\hline Psychotria vauthieri Müll.Arg. & St & & 0 & 0 & 1 & 0 & 0 & 0 & 0 \\
\hline Randia armata (Sw.) DC. & & & 0 & 0 & 0 & 0 & 0 & 1 & 0 \\
\hline Rubiaceae 1 & & & 0 & 0 & 0 & 0 & 0 & 0 & 1 \\
\hline $\begin{array}{l}\text { Rudgea jasminoides (Cham.) } \\
\text { Müll.Arg. }\end{array}$ & St & & 1 & 0 & 0 & 0 & 0 & 0 & 0 \\
\hline \multicolumn{10}{|l|}{ RUTACEAE } \\
\hline Balfourodendron riedelianum Engl. & St & pau marfim & 1 & 1 & 1 & 0 & 1 & 1 & $\overline{0}$ \\
\hline Cusparia paniculata Engl. & Sc & & 0 & 0 & 1 & 0 & 0 & 0 & 0 \\
\hline $\begin{array}{l}\text { Esenbeckia febrifuga (A.St.-Hil.) } \\
\text { A.Juss.ex Mart. }\end{array}$ & Si & mamoninha & 1 & 1 & 1 & 1 & 0 & 1 & 1 \\
\hline Esenbeckia leiocarpa Engl. & St & guarantã & 1 & 1 & 1 & 0 & 0 & 0 & 0 \\
\hline Esenbeckia grandiflora Mart. & & & 0 & 0 & 0 & 1 & 0 & 0 & 0 \\
\hline Galipea jasminiflora (A.St.-Hil.) Engl. & St & & 0 & 1 & 1 & 0 & 0 & 0 & 0 \\
\hline Galipea jasminiflora (A.St.-Hil.) Engl. & St & & 1 & 0 & 1 & 0 & 0 & 1 & 1 \\
\hline Metrodorea nigra A.St.-Hil. & St & chupa-ferro & 1 & 1 & 0 & 1 & 1 & 1 & 0 \\
\hline Metrodorea stipularis Mart. & St & & 1 & 1 & 1 & 1 & 0 & 0 & 0 \\
\hline Pilocarpus pauciflorus A.St.-Hil. & Sc & & 1 & 0 & 0 & 0 & 0 & 0 & 0 \\
\hline Zanthoxyllum sp1 & & & 0 & 0 & 0 & 0 & 1 & 0 & 0 \\
\hline $\begin{array}{l}\text { Zanthoxyllum chiloperone Mart. ex } \\
\text { Engl. }\end{array}$ & $\mathrm{Si}$ & mamiqueira & 0 & 0 & 1 & 0 & 1 & 0 & 0 \\
\hline Zanthoxylum hiemale A.St.-Hil. & $P$ & $\begin{array}{l}\text { mamica de } \\
\text { porca }\end{array}$ & 1 & 1 & 1 & 0 & 0 & 0 & 0 \\
\hline $\begin{array}{l}\text { Zanthoxylum juniperinum Poepp. \& } \\
\text { Endl. }\end{array}$ & Si & $\begin{array}{l}\text { mamica de } \\
\text { porca }\end{array}$ & 1 & 0 & 1 & 0 & 0 & 0 & 0 \\
\hline Zanthoxylum minutiflorum Tul. & Sc & $\begin{array}{c}\text { mamica de } \\
\text { porca }\end{array}$ & 0 & 0 & 1 & 0 & 0 & 0 & 0 \\
\hline Zanthoxylum monogynum A.St.-Hil. & Si & $\begin{array}{l}\text { mamica de } \\
\text { porca }\end{array}$ & 1 & 1 & 1 & 0 & 0 & 1 & 0 \\
\hline Zanthoxylum pohlianum Engl. & Si & mamica de & 0 & 0 & 1 & 0 & 0 & 0 & 0 \\
\hline
\end{tabular}




\begin{tabular}{|c|c|c|c|c|c|c|c|c|c|}
\hline & & porca & & & & & & & \\
\hline Zanthoxylum regnellianum Engl. & Sc & $\begin{array}{l}\text { mamica de } \\
\text { porca }\end{array}$ & 0 & 0 & 1 & 0 & 0 & 0 & 0 \\
\hline \multicolumn{10}{|l|}{ SAPINDACEAE } \\
\hline Allophylus edulis (A.St.-Hil.) Radlk. & $\mathrm{P}$ & fruta de faraó & 1 & 1 & 1 & 0 & 1 & 1 & 0 \\
\hline Cupania vernalis Cambess. & $\mathrm{Si}$ & camboatã & 1 & 0 & 1 & 0 & 1 & 1 & 0 \\
\hline Diatenopteryx sorbifolia Radlk. & $\mathrm{Si}$ & maria preta & 1 & 1 & 1 & 0 & 0 & 1 & 0 \\
\hline Matayba guianensis Aubl. & & & 0 & 0 & 0 & 0 & 0 & 1 & 0 \\
\hline Serjania aff. fuscifolia Radlk. & & & 0 & 0 & 0 & 1 & 0 & 0 & 0 \\
\hline Serjania communis Camb. & & & 0 & 0 & 0 & 1 & 1 & 0 & 0 \\
\hline Serjania hebecarpa Benth. & & & 0 & 0 & 0 & 0 & 1 & 0 & 0 \\
\hline Urvillea laevis Raldk. & & & 0 & 0 & 0 & 1 & 0 & 0 & 0 \\
\hline \multicolumn{10}{|l|}{ SAPOTACEAE } \\
\hline $\begin{array}{l}\text { Chrysophyllum gonocarpum (Mart. \& } \\
\text { Eichl.) Engl. }\end{array}$ & St & $\begin{array}{c}\text { guatambú de } \\
\text { leite }\end{array}$ & 1 & 1 & 1 & 1 & 0 & 1 & 0 \\
\hline \multicolumn{10}{|l|}{ SIMAROUBACEAE } \\
\hline Picramnia warmingiana Engl. & St & & 1 & 0 & 1 & 0 & 0 & 1 & 0 \\
\hline \multicolumn{10}{|l|}{ SMILACACEAE } \\
\hline Smilax cf. fluminensis Steud. & & & 0 & 0 & 0 & 0 & 1 & 0 & 0 \\
\hline \multicolumn{10}{|l|}{ SOLANACEAE } \\
\hline Cestrum sp1 & & & 0 & 0 & 0 & 0 & 0 & 1 & 0 \\
\hline Cestrum schlechtendalii G.Don & $\mathrm{P}$ & & 0 & 0 & 1 & 0 & 0 & 1 & 0 \\
\hline Cestrum sessiflorum Schott & & & 0 & 0 & 0 & 1 & 0 & 0 & 1 \\
\hline Solanum acerifolium Mil. & $\mathrm{P}$ & & 1 & 0 & 0 & 0 & 0 & 0 & 0 \\
\hline Solanum argenteum Dunal & $\mathrm{P}$ & & 1 & 0 & 1 & 1 & 0 & 0 & 0 \\
\hline $\begin{array}{l}\text { Solanum concinnum Schott ex } \\
\text { Sendtn. }\end{array}$ & & & 1 & 0 & 0 & 0 & 1 & 0 & 0 \\
\hline Solanum gracillimum Sendtn. & & & 0 & 0 & 0 & 0 & 1 & 0 & 0 \\
\hline Solanum granulosum-leprosum Dunal & & & 0 & 0 & 0 & 1 & 0 & 0 & 0 \\
\hline Solanum hoehnei Morton & & & 0 & 0 & 0 & 0 & 1 & 0 & 0 \\
\hline $\begin{array}{l}\text { Solanum swartzianum Roem. \& } \\
\text { Schult. }\end{array}$ & $P$ & fumo bravo & 0 & 0 & 1 & 0 & 0 & 0 & 0 \\
\hline \multicolumn{10}{|l|}{ STERCULIACEAE } \\
\hline Guazuma ulmifolia Lam. & $\mathrm{P}$ & mutambo & 0 & 1 & 1 & 0 & 0 & 0 & 0 \\
\hline Helicteres cf. eichlerii K.Schum. & $\mathrm{P}$ & saca-rolha & 0 & 0 & 0 & 1 & 1 & 0 & 0 \\
\hline \multicolumn{10}{|l|}{ STYRACACEAE } \\
\hline Styrax glaber Sw. & St & & 0 & 1 & 1 & 0 & 0 & 0 & 0 \\
\hline Styrax pohlii A.DC. & & & 0 & 0 & 0 & 1 & 0 & 1 & 1 \\
\hline \multicolumn{10}{|l|}{ THEACEAE } \\
\hline Laplacea semiserrata Cambess. & St & & 0 & 0 & 1 & 0 & 0 & 0 & 0 \\
\hline \multicolumn{10}{|l|}{ TILIACEAE } \\
\hline Luehea divaricata Mart. & & açoita-cavalo & 1 & 1 & 1 & 0 & 0 & 1 & 1 \\
\hline Luehea speciosa Willd. & Si & açoita-cavalo & 0 & 0 & 1 & 0 & 0 & 0 & 0 \\
\hline \multicolumn{10}{|l|}{ ULMACEAE } \\
\hline Celtis iguanae (Jacq.) Sargent & & grão de galo & 1 & 0 & 0 & 1 & 1 & 1 & 0 \\
\hline Celtis tala Gillies ex Planch. & $P$ & grão de galo & 1 & 0 & 1 & 0 & 0 & 0 & 0 \\
\hline Trema micrantha Blume & & paú polvora & 1 & 0 & 1 & 1 & 1 & 0 & 0 \\
\hline \multicolumn{10}{|l|}{ URTICACEAE } \\
\hline Urera baccifera (L.) Gaudich. & $\mathrm{P}$ & urtigão & 1 & 1 & 1 & 1 & 0 & 0 & 0 \\
\hline
\end{tabular}




\begin{tabular}{|l|c|c|c|c|c|c|c|c|c|}
\hline VERBENACEAE & & & & & & & & & \\
\hline Aegiphila sellowiana Cham. & $\mathrm{P}$ & tamanqueira & 0 & 1 & 1 & 1 & 1 & 0 & 0 \\
\hline Aloysia virgata (Ruiz \& Pav.) A.Juss. & $\mathrm{P}$ & lixeira & 0 & 1 & 0 & 1 & 1 & 1 & 0 \\
\hline Cytharexylum myrianthum Cham. & & pau-viola & 0 & 0 & 0 & 0 & 0 & 0 & 1 \\
\hline Lantana camara L. & & lantana & 0 & 0 & 0 & 0 & 1 & 0 & 0 \\
\hline Vitex aff. montevidensis Cham. & Sc & & 0 & 0 & 1 & 0 & 0 & 0 & 0 \\
\hline VIOLACEAE & & & & & & & & & \\
\hline $\begin{array}{l}\text { Hybanthus atropurpureus (A.St.-Hil.) } \\
\text { Taub. }\end{array}$ & & 1 & 0 & 0 & 1 & 0 & 1 & 1 \\
\hline VITACEAE & & & & & & & & & \\
\hline Cissus bahiensis Lombardi & & & 0 & 0 & 0 & 0 & 1 & 0 & 0 \\
\hline Cissus sulcicaulis Bauner & & & 0 & 0 & 0 & 1 & 0 & 0 & 0 \\
\hline VOCHYSIACEAE & & & & & & & & & \\
\hline Qualea jundiahy Warm. & St & pau-terra & 0 & 0 & 1 & 0 & 0 & 0 & 0 \\
\hline
\end{tabular}


ANEXO B 


\section{Parâmetros fitossociológicos da unidade ecológica "floresta paludosa" na Reserva Municipal de Santa Genebra, Campinas, SP.}

No. de parcelas $=75$

Comprimento da parcela $(\mathrm{m})=10.0 \quad$ Largura da parcela $(\mathrm{m})=2.0$

área de cada parcela $\left(\mathrm{m}^{2}\right)=20.00$ área total da amostra(ha) $=0.150$

No. de indivíduos $=2070 \quad$ densidade total $=13800.00$

Área basal total $\left(\mathrm{m}^{2}\right)=5.818 \quad$ Volume total $\left(\mathrm{m}^{3}\right)=55.67$

Área basal por hectare $=38.787$

Frequência total $=1281.3$

Diâmetro máximo $=47.43 \quad$ Diâmetro mínimo $=0.32$

Diâmetro médio $=3.58$ d.p. Diâmetro $=4.792$

Altura máximo $=18.00 \quad$ Altura mínimo $=1.00$

Altura média $=3.52 \quad$ d.p. Altura $=2.726$

Volume máximo $=2.650 \quad$ Volume mínimo $=0.0000$

Volume médio $=0.027$ d.p. Volume $=0.1395$

No. de espécies $(\mathrm{S})=105 \quad$ Índice Shannon $\left(\mathrm{H}^{\prime}\right)=3.47$

equabilidade $\left(\mathrm{J}=\mathrm{H}^{\prime} / \ln (\mathrm{S})\right)=0.746$

Índice Simpson $(D)=0.064 \quad 1 / D=15.708 \quad 1-D=0.936$

No. de famílias $=39 \quad$ Índice Shannon para famílias $=2.631$ 
Parâmetros fitossociológicos das espécies amostradas em trechos da unidade ecológica "Floresta de brejo" na Reserva Municipal de Santa Genebra, Município de Campinas, SP. NInd. = número de indivíduos; Dens.Rel. = densidade relativa (\%); Dom.Rel. = dominância relativa (\%); Freq. Rel. = frequência relativa (\%); IVI = índice de valor de importância; IVC $=$ índice de valor de cobertura.

\begin{tabular}{|c|c|c|c|c|c|c|}
\hline espécie & No. Ind & Dens.Rel & Dom.Rel & Freq.Re] & IVI & IVC \\
\hline 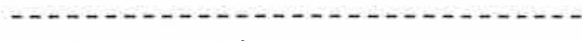 & & 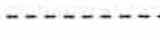 & $\cdots$ & $\cdots$ & 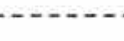 & -- \\
\hline Euterpe edulis............. & 220 & 10.63 & 21.05 & 6.34 & 38.02 & 31.68 \\
\hline Geonoma brevispatha......... & 381 & 18.41 & 3.39 & 5.93 & 27.72 & 21.79 \\
\hline 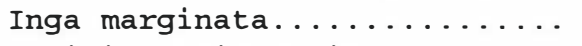 & 118 & 5.70 & 10.65 & 4.89 & 21.24 & 16.35 \\
\hline Tapirira guianensis......... & 54 & 2.61 & 10.78 & 3.01 & 16.40 & 13.39 \\
\hline Protium cf. heptaphyllum..... & 111 & 5.36 & 2.93 & 4.89 & 13.18 & 8.29 \\
\hline 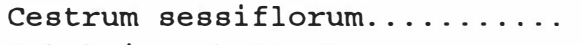 & 134 & 6.47 & 0.23 & 5.51 & 12.22 & 6.71 \\
\hline 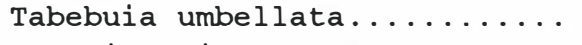 & 18 & 0.87 & 6.99 & 1.56 & 9.42 & 7.86 \\
\hline Eugenia stictosepala........ & 65 & 3.14 & 2.39 & 3.22 & 8.75 & 5.53 \\
\hline Endlicheria paniculata...... & 70 & 3.38 & 1.18 & 3.74 & 8.30 & 4.56 \\
\hline Psychotria mapourioides...... & 94 & 4.54 & 0.23 & 3.22 & 8.00 & 4.78 \\
\hline 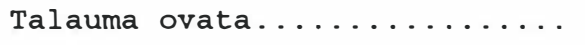 & 31 & 1.50 & 3.20 & 2.49 & 7.19 & 4.69 \\
\hline Tapirira cf. obtusa......... & 31 & 1.50 & 3.13 & 2.18 & 6.81 & 4.62 \\
\hline 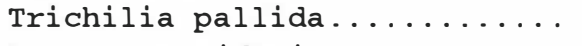 & 33 & 1.59 & 2.70 & 2.08 & 6.38 & 4.30 \\
\hline 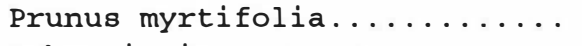 & 18 & 0.87 & 3.20 & 1.66 & 5.73 & 4.07 \\
\hline Sebastiania serrata......... & 41 & 1.98 & 1.35 & 2.18 & 5.51 & 3.33 \\
\hline Sebastiania commersoniana.... & 31 & 1.50 & 2.12 & 1.66 & 5.28 & 3.62 \\
\hline 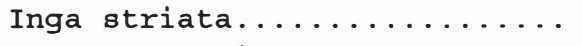 & 29 & 1.40 & 2.41 & 1.35 & 5.17 & 3.82 \\
\hline Guarea kunthiana............ & 37 & 1.79 & 0.61 & 2.70 & 5.10 & 2.40 \\
\hline Syagrus romanzoffiana........ & 11 & 0.53 & 3.12 & 1.04 & 4.69 & 3.65 \\
\hline Guarea macrophylla......... & 38 & 1.84 & 0.36 & 1.87 & 4.07 & 2.20 \\
\hline Andira cf. Inermis.......... & 3 & 0.14 & 3.10 & 0.21 & 3.45 & 3.24 \\
\hline Alchornea triplinervia...... & 7 & 0.34 & 2.46 & 0.62 & 3.42 & 2.80 \\
\hline Copaifera langsdorffii...... & 17 & 0.82 & 0.93 & 1.56 & 3.31 & 1.75 \\
\hline Protium cf. widgrenii....... & 7 & 0.34 & 2.00 & 0.73 & 3.06 & 2.33 \\
\hline 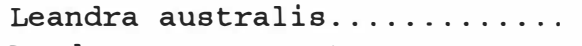 & 29 & 1.40 & 0.05 & 1.35 & 2.80 & 1.45 \\
\hline Dendropanax cuneatum........ & 19 & 0.92 & 0.36 & 1.46 & 2.74 & 1.28 \\
\hline Lauraceae $1 \ldots \ldots \ldots \ldots \ldots$ & 21 & 1.01 & 0.35 & 1.25 & 2.61 & 1.36 \\
\hline Pseudobombax grandiflorum.... & 4 & 0.19 & 1.97 & 0.31 & 2.47 & 2.16 \\
\hline Psychotria sessilis......... & 26 & 1.26 & 0.07 & 1.14 & 2.47 & 1.32 \\
\hline 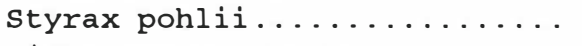 & 12 & 0.58 & 0.90 & 0.94 & 2.42 & 1.48 \\
\hline Didymopanax calvum.......... & 2 & 0.10 & 1.91 & 0.21 & 2.22 & 2.01 \\
\hline 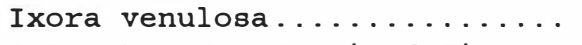 & 15 & 0.72 & 0.13 & 1.35 & 2.21 & 0.86 \\
\hline Calypthrantes clusiaefolia... & 14 & 0.68 & 0.26 & 1.25 & 2.19 & 0.94 \\
\hline Psychotria hoffmanseggiana... & 16 & 0.77 & 0.05 & 1.35 & 2.17 & 0.82 \\
\hline Guapira opposita............ & 10 & 0.48 & 0.58 & 0.94 & 2.00 & 1.06 \\
\hline Rubiaceae $2 \ldots \ldots \ldots \ldots \ldots$ & 19 & 0.92 & 0.03 & 1.04 & 1.99 & 0.95 \\
\hline Galipea multiflora.......... & 12 & 0.58 & 0.03 & 1.14 & 1.76 & 0.61 \\
\hline Miconia ligustroides........ & 13 & 0.63 & 0.15 & 0.94 & 1.72 & 0.78 \\
\hline 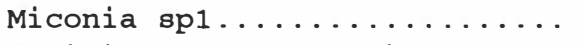 & 13 & 0.63 & 0.01 & 0.83 & 1.47 & 0.64 \\
\hline Cariniana estrellensis....... & 11 & 0.53 & 0.10 & 0.83 & 1.47 & 0.63 \\
\hline Miconia hymenonervia........ & 10 & 0.48 & 0.01 & 0.94 & 1.43 & 0.50 \\
\hline 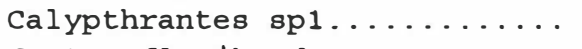 & 9 & 0.43 & 0.02 & 0.94 & 1.39 & 0.46 \\
\hline Croton floribundus.......... & 7 & 0.34 & 0.41 & 0.62 & 1.37 & 0.74 \\
\hline 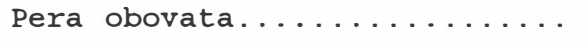 & 8 & 0.39 & 0.23 & 0.73 & 1.35 & 0.62 \\
\hline Alchornea glandulosa......... & 6 & 0.29 & 0.41 & 0.52 & 1.22 & 0.70 \\
\hline Rapanea intermedia.......... & 9 & 0.43 & 0.32 & 0.42 & 1.17 & 0.76 \\
\hline Piper amplum.............. & 10 & 0.48 & 0.01 & 0.62 & 1.12 & 0.49 \\
\hline
\end{tabular}


Cont.

\begin{tabular}{|c|c|c|c|c|c|c|}
\hline espécie & No. Ind & Dens.Rel & Dom.Rel & Freq.Rel & IVI & IVC \\
\hline \multicolumn{7}{|c|}{ 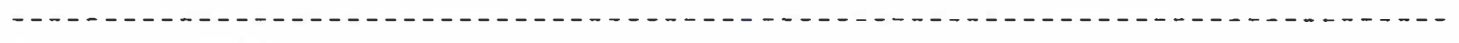 } \\
\hline Eugenia florida............ & 7 & 0.34 & 0.01 & 0.73 & 1.08 & 0.35 \\
\hline Dorstenia hirta............ & 14 & 0.68 & 0.02 & 0.31 & 1.01 & 0.70 \\
\hline 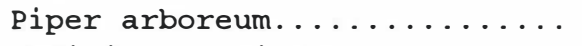 & 9 & 0.43 & 0.02 & 0.52 & 0.98 & 0.46 \\
\hline Ardisia glauciflora.......... & 6 & 0.29 & 0.02 & 0.62 & 0.93 & 0.31 \\
\hline Ruellia sanguinea.......... & 6 & 0.29 & 0.00 & 0.62 & 0.92 & 0.29 \\
\hline Cedrela fissilis............ & 6 & 0.29 & 0.06 & 0.52 & 0.87 & 0.35 \\
\hline Sorocea bonplandii......... & 5 & 0.24 & 0.03 & 0.52 & 0.79 & 0.27 \\
\hline Cabralea canjerana.......... & 4 & 0.19 & 0.11 & 0.42 & 0.72 & 0.30 \\
\hline 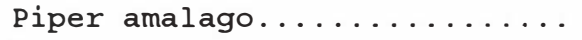 & 8 & 0.39 & 0.01 & 0.31 & 0.71 & 0.39 \\
\hline 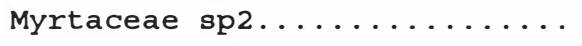 & 5 & 0.24 & 0.03 & 0.42 & 0.68 & 0.27 \\
\hline Ocotea beulahiae............ & 5 & 0.24 & 0.02 & 0.42 & 0.68 & 0.26 \\
\hline Nectandra megapotanica....... & 5 & 0.24 & 0.02 & 0.42 & 0.67 & 0.26 \\
\hline 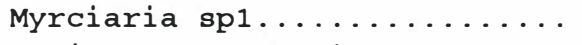 & 6 & 0.29 & 0.03 & 0.31 & 0.63 & 0.32 \\
\hline Lacistema hasslerianum...... & 4 & 0.19 & 0.01 & 0.42 & 0.62 & 0.21 \\
\hline Merostachys riedeliana....... & 4 & 0.19 & 0.00 & 0.42 & 0.61 & 0.20 \\
\hline 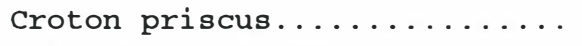 & 3 & 0.10 & 0.29 & 0.21 & 0.60 & 0.39 \\
\hline Polygala klotzschii......... & 5 & 0.24 & 0.00 & 0.31 & 0.55 & 0.24 \\
\hline Psychotria brachybotrya...... & 4 & 0.19 & 0.01 & 0.31 & 0.51 & 0.20 \\
\hline 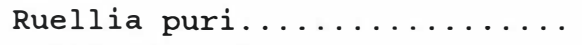 & 4 & 0.19 & 0.01 & 0.31 & 0.51 & 0.20 \\
\hline Mollinedia widgrenii........ & 4 & 0.19 & 0.00 & 0.31 & 0.51 & 0.20 \\
\hline Ossaea bachystachya.......... & 4 & 0.19 & 0.00 & 0.31 & 0.51 & 0.20 \\
\hline Luehea divaricata........... & 3 & 0.14 & 0.02 & 0.31 & 0.48 & 0.17 \\
\hline Eugenia cf. ligustrina....... & 3 & 0.14 & 0.01 & 0.31 & 0.47 & 0.15 \\
\hline 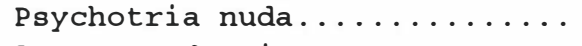 & 3 & 0.14 & 0.00 & 0.31 & 0.46 & 0.15 \\
\hline Ixora gardneriana............ & 3 & 0.14 & 0.02 & 0.21 & 0.38 & 0.17 \\
\hline Duguetia lanceolata......... & 3 & 0.14 & 0.02 & 0.21 & 0.37 & 0.16 \\
\hline Trichilia catigua............ & 2 & 0.10 & 0.02 & 0.21 & 0.32 & 0.11 \\
\hline Myrcia cf. rostrata......... & 2 & 0.10 & 0.01 & 0.21 & 0.32 & 0.11 \\
\hline Leandra alterminervia....... & 2 & 0.10 & 0.01 & 0.21 & 0.31 & 0.11 \\
\hline Machaerium aculeatum........ & 2 & 0.10 & 0.01 & 0.21 & 0.31 & 0.10 \\
\hline Sloanea monosperma......... & 2 & 0.10 & 0.00 & 0.21 & 0.31 & 0.10 \\
\hline Commelina obliqua........... & 2 & 0.10 & 0.00 & 0.21 & 0.31 & 0.10 \\
\hline 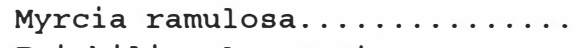 & 1 & 0.05 & 0.07 & 0.10 & 0.22 & 0.11 \\
\hline Trichilia clausseni......... & 2 & 0.10 & 0.01 & 0.10 & 0.21 & 0.11 \\
\hline Piptadenia gonoacantha....... & 1 & 0.05 & 0.05 & 0.10 & 0.21 & 0.10 \\
\hline Psychotria carthagenensis.... & 2 & 0.10 & 0.00 & 0.10 & 0.21 & 0.10 \\
\hline 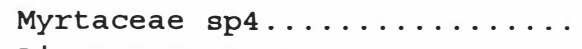 & 2 & 0.10 & 0.00 & 0.10 & 0.20 & 0.10 \\
\hline Piper argenteum............ & 2 & 0.10 & 0.00 & 0.10 & 0.20 & 0.10 \\
\hline Cecropia pachystachya........ & 1 & 0.05 & 0.04 & 0.10 & 0.19 & 0.09 \\
\hline Cytharexylum myrianthum..... & 1 & 0.05 & 0.03 & 0.10 & 0.18 & 0.08 \\
\hline Astronium graveolens......... & 1 & 0.05 & 0.02 & 0.10 & 0.17 & 0.06 \\
\hline Myrtaceae sp $3 \ldots \ldots \ldots \ldots$ & 1 & 0.05 & 0.01 & 0.10 & 0.17 & 0.06 \\
\hline Savia dyctiocarpa........... & 1 & 0.05 & 0.01 & 0.10 & 0.16 & 0.06 \\
\hline Myroxylon peruiferum........ & 1 & 0.05 & 0.01 & 0.10 & 0.16 & 0.06 \\
\hline Trichilia casaretti......... & 1 & 0.05 & 0.01 & 0.10 & 0.16 & 0.06 \\
\hline Cordia selowiana............. & 1 & 0.05 & 0.00 & 0.10 & 0.16 & 0.05 \\
\hline Aspidosperma polyneuron...... & 1 & 0.05 & 0.00 & 0.10 & 0.16 & 0.05 \\
\hline Hybanthus atropurpureus ..... & 1 & 0.05 & 0.00 & 0.10 & 0.15 & 0.05 \\
\hline Miconia chamissois.......... & 1 & 0.05 & 0.00 & 0.10 & 0.15 & 0.05 \\
\hline Miconia sp $3 \ldots \ldots \ldots \ldots \ldots$ & 1 & 0.05 & 0.00 & 0.10 & 0.15 & 0.05 \\
\hline Miconia discolor............ & 1 & 0.05 & 0.00 & 0.10 & 0.15 & 0.05 \\
\hline 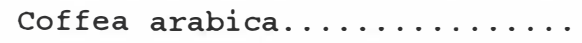 & 1 & 0.05 & 0.00 & 0.10 & 0.15 & 0.05 \\
\hline
\end{tabular}


Cont.

\begin{tabular}{|c|c|c|c|c|c|c|}
\hline espécie & No. Ind & Dens.Rel & Dom.Rel & Freq.Rel & IVI & IVC \\
\hline 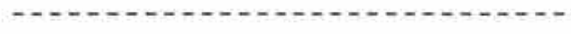 & & - & $\cdots$ & $\ldots$ & $-\infty$ & $\ldots$ \\
\hline Miconia sp2. & 1 & 0.05 & 0.00 & 0.10 & 0.15 & 0.05 \\
\hline Piper marginatum .......... & 1 & 0.05 & 0.00 & 0.10 & 0.15 & 0.05 \\
\hline xylopia brasiliensis......... & 1 & 0.05 & 0.00 & 0.10 & 0.15 & 0.05 \\
\hline Esenbeckia febrifuga........ & 1 & 0.05 & 0.00 & 0.10 & 0.15 & 0.05 \\
\hline ocotea odorifera........... & 1 & 0.05 & 0.00 & 0.10 & 0.15 & 0.05 \\
\hline Myrtaceae $\operatorname{sp} 1 \ldots \ldots \ldots \ldots$ & 1 & 0.05 & 0.00 & 0.10 & 0.15 & 0.05 \\
\hline
\end{tabular}


Parâmetros fitossociológicos das famílias amostradas em trechos da unidade ecológica "Floresta de brejo" na Reserva Municipal de Santa Genebra, Município de Campinas, SP. $\mathrm{N}^{\circ}$ Ind. = número de indivíduos; $\mathrm{N}^{\circ} . \mathrm{Spp}=$ número de espécies; Dens.Rel. = densidade relativa $(\%) ;$ Dom. Rel. = dominância relativa $(\%)$; Freq. Rel. $=$ frequência relativa $(\%)$; IVI = índice de valor de importância; IVC = índice de valor de cobertura

\begin{tabular}{|c|c|c|c|c|c|c|c|}
\hline famflia & No. Ind & No.Spp & Dens.Rel & Dom.Rel & Freq.Rel & IVI & IVC \\
\hline Arecaceae......... & 612 & 3 & 29.57 & 27.55 & 9.49 & 66.61 & 57.12 \\
\hline Rubiaceae......... & 183 & 10 & 8.84 & 0.55 & 6.42 & 15.81 & 9.39 \\
\hline Mimosaceae........ & 148 & 3 & 7.15 & 13.12 & 6.68 & 26.95 & 20.27 \\
\hline Solanacea.......... & 134 & 1 & 6.47 & 0.23 & 7.09 & 13.79 & 6.71 \\
\hline Meliaceae......... & 124 & 8 & 5.99 & 3.88 & 7.75 & 17.62 & 9.87 \\
\hline Burseraceae........ & 118 & 2 & 5.70 & 4.93 & 6.82 & 17.44 & 10.63 \\
\hline Myrtaceae......... & 116 & 12 & 5.60 & 2.86 & 6.68 & 15.14 & 8.46 \\
\hline Euphorbiaceae...... & 104 & 8 & 5.02 & 7.29 & 6.28 & 18.60 & 12.31 \\
\hline Lauraceae......... & 102 & 5 & 4.93 & 1.56 & 6.15 & 12.64 & 6.49 \\
\hline Anacardiaceae...... & 86 & 3 & 4.15 & 13.92 & 5.88 & 23.96 & 18.08 \\
\hline Melastomataceae.... & 75 & 10 & 3.62 & 0.24 & 4.01 & 7.88 & 3.87 \\
\hline Magnoliaceae....... & 31 & 1 & 1.50 & 3.20 & 3.21 & 7.90 & 4.69 \\
\hline Piperaceae........ & 30 & 5 & 1.45 & 0.04 & 2.01 & 3.50 & 1.49 \\
\hline 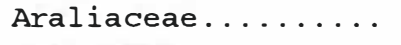 & 21 & 2 & 1.01 & 2.28 & 2.01 & 5.30 & 3.29 \\
\hline 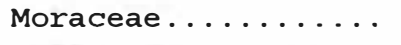 & 19 & 2 & 0.92 & 0.05 & 1.07 & 2.04 & 0.97 \\
\hline 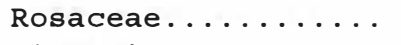 & 18 & 1 & 0.87 & 3.20 & 2.14 & 6.21 & 4.07 \\
\hline Bignoniaceae...... & 18 & 1 & 0.87 & 6.99 & 2.01 & 9.86 & 7.86 \\
\hline Caesalpiniaceae.... & 17 & 1 & 0.82 & 0.93 & 2.01 & 3.75 & 1.75 \\
\hline Myrsinaceae........ & 15 & 2 & 0.72 & 0.34 & 1.20 & 2.27 & 1.06 \\
\hline Rutaceae......... & 13 & 2 & 0.63 & 0.03 & 1.47 & 2.13 & 0.66 \\
\hline styracaceae....... & 12 & 1 & 0.58 & 0.90 & 1.20 & 2.68 & 1.48 \\
\hline Lecythidaceae...... & 11 & 1 & 0.53 & 0.10 & 1.07 & 1.70 & 0.63 \\
\hline Acanthaceae....... & 10 & 2 & 0.48 & 0.01 & 1.20 & 1.70 & 0.49 \\
\hline Nyctaginacea....... & 10 & 1 & 0.48 & 0.58 & 1.20 & 2.26 & 1.06 \\
\hline Fabaceae.......... & 6 & 3 & 0.29 & 3.11 & 0.67 & 4.07 & 3.40 \\
\hline Polygalaceae....... & 5 & 1 & 0.24 & 0.00 & 0.40 & 0.64 & 0.24 \\
\hline Annonaceae........ & 4 & 2 & 0.19 & 0.02 & 0.40 & 0.61 & 0.21 \\
\hline Poaceae.......... & 4 & 1 & 0.19 & 0.00 & 0.53 & 0.73 & 0.20 \\
\hline Monimiaceae....... & 4 & 1 & 0.19 & 0.00 & 0.40 & 0.60 & 0.20 \\
\hline Lacistemataceae.... & 4 & 1 & 0.19 & 0.01 & 0.53 & 0.74 & 0.21 \\
\hline Bombacaceae....... & 4 & 1 & 0.19 & 1.97 & 0.40 & 2.56 & 2.16 \\
\hline 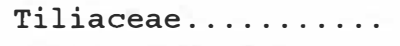 & 3 & 1 & 0.14 & 0.02 & 0.40 & 0.57 & 0.17 \\
\hline Elaeocarpaceae..... & 2 & 1 & 0.10 & 0.00 & 0.27 & 0.37 & 0.10 \\
\hline Commelinaceae...... & 2 & 1 & 0.10 & 0.00 & 0.27 & 0.36 & 0.10 \\
\hline Cecropiaceae...... & 1 & 1 & 0.05 & 0.04 & 0.13 & 0.22 & 0.09 \\
\hline Violaceae......... & 1 & 1 & 0.05 & 0.00 & 0.13 & 0.18 & 0.05 \\
\hline Verbenaceae....... & 1 & 1 & 0.05 & 0.03 & 0.13 & 0.21 & 0.08 \\
\hline Boraginaceae....... & 1 & 1 & 0.05 & 0.00 & 0.13 & 0.19 & 0.05 \\
\hline Apocynaceae........ & 1 & 1 & 0.05 & 0.00 & 0.13 & 0.19 & 0.05 \\
\hline
\end{tabular}


ANEXO C 


\section{Parâmetros fitossociológicos da unidade ecológica "Maciço de Diatenopteryx sorbifolia Radlk." (Maria Preta) na Reserva Municipal de Santa Genebra, Campinas, SP.}

No. de parcelas $=75$

Comprimento da parcela $(\mathrm{m})=10.0 \quad$ Largura da parcela $(\mathrm{m})=2.0$

área de cada parcela $\left(\mathrm{m}^{2}\right)=20.00$ área total da amostra $(\mathrm{ha})=0.150$

No. de indivíduos $=2505 \quad$ densidade total $=16700.00$

Área basal total $\left(\mathrm{m}^{2}\right)=11.351 \quad$ Volume total $\left(\mathrm{m}^{3}\right)=234.61$

Área basal por hectare $=75.676$

Frequência total $=1056.0$

Diâmetro máximo $=82.76$ Diâmetro mínimo $=0.32$

Diâmetro médio $=2.81$ d.p. Diâmetro $=7.059$

Altura máximo $=30.00 \quad$ Altura mínimo $=1.00$

Altura média $=2.81 \quad$ d.p. Altura $=3.291$

Volume máximo $=12.932 \quad$ Volume mínimo $=0.0000$

Volume médio $=0.094 \quad$ d.p. Volume $=0.7915$

No. de espécies $(\mathrm{S})=93 \quad$ Índice Shannon $\left(\mathrm{H}^{\prime}\right)=2.539$ equabilidade $\left(\mathrm{J}=\mathrm{H}^{\prime} / \ln (\mathrm{S})\right)=0.560$

Índice Simpson $(D)=0.190 \quad 1 / D=5.276 \quad 1-D=0.810$

No. de famílias $=39 \quad$ Índice Shannon para famílias $=1.873$ 
Parâmetros fitossociológicos das espécies amostradas em trechos da unidade ecológica "Maciço de Diatencpteryx sorbifolia Radlk." na Reserva Municipal de Santa Genebra, Municipio de Campinas, SP. N $^{\circ}$ Ind. = número de indivíduos; Dens. Rel. = densidade relativa (\%); Dom.Rel. = dominância relativa (\%); Freq.Rel. = frequência relativa (\%); IVI = indice de valor de importância; IVC = indice de valor de cobertura.

\begin{tabular}{|c|c|c|c|c|c|c|}
\hline espécie & No & Dens & Dom & Freq.Rel & IVI & IVC \\
\hline Diatenopteryx sorbifolia... & 63 & 2.51 & 61.61 & 5.05 & 69.18 & 64.13 \\
\hline Actinostemon klotschii.... & 1007 & 40.20 & 3.08 & 9.22 & 52.49 & 43.28 \\
\hline Metrodorea nigra.......... & 275 & 10.98 & 4.62 & 5.18 & 20.77 & 15.60 \\
\hline Aspidosperma polyneuron.... & 160 & 6.39 & 0.26 & 7.83 & 14.48 & 6.65 \\
\hline Sebastiania serrata........ & 135 & 5.39 & 1.36 & 7.07 & 13.82 & 6.75 \\
\hline 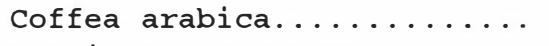 & 156 & 6.23 & 0.23 & 6.44 & 12.89 & 6.45 \\
\hline Myrcia cf. rostrata........ & 91 & 3.63 & 2.48 & 5.18 & 11.29 & 6.12 \\
\hline Machaerium vestitum....... & 22 & 0.88 & 8.09 & 1.89 & 10.86 & 8.97 \\
\hline Trichilia casaretti....... & 79 & 3.15 & 0.16 & 5.81 & 9.12 & 3.32 \\
\hline Galipea multiflora........ & 86 & 3.43 & 0.82 & 4.80 & 9.06 & 4.26 \\
\hline Luehea divaricata.......... & 1 & 0.04 & 4.67 & 0.13 & 4.83 & 4.71 \\
\hline Balfourodendron riedelianum. & 1 & 0.04 & 4.38 & 0.13 & 4.55 & 4.42 \\
\hline Psychotria brachyceras..... & 39 & 1.56 & 0.11 & 2.78 & 4.44 & 1.66 \\
\hline Trichilia catigua.......... & 32 & 1.28 & 0.12 & 2.78 & 4.18 & 1.40 \\
\hline Psychotria brachybotrya.... & 33 & 1.32 & 0.08 & 2.40 & 3.79 & 1.40 \\
\hline Copaifera langsdorffii..... & 2 & 0.08 & 3.46 & 0.25 & 3.79 & 3.54 \\
\hline Eugenia cf. ligustrina..... & 31 & 1.24 & 0.04 & 2.02 & 3.29 & 1.27 \\
\hline Polygala klotzschii....... & 21 & 0.84 & 0.01 & 1.89 & 2.74 & 0.85 \\
\hline Eugenia pyriformis........ & 20 & 0.80 & 0.02 & 1.77 & 2.59 & 0.82 \\
\hline Chrysophyllum gonocarpum.... & 14 & 0.56 & 0.02 & 1.52 & 2.10 & 0.58 \\
\hline Cryptocarya aschersoniana... & 2 & 0.08 & 1.64 & 0.25 & 1.97 & 1.72 \\
\hline Mollinedia clavigera....... & 14 & 0.56 & 0.08 & 1.14 & 1.78 & 0.64 \\
\hline 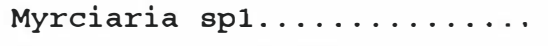 & 14 & 0.56 & 0.03 & 1.14 & 1.72 & 0.59 \\
\hline Coussarea contracta........ & 9 & 0.36 & 0.01 & 1.14 & 1.51 & 0.37 \\
\hline 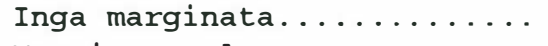 & 12 & 0.48 & 0.01 & 1.01 & 1.50 & 0.49 \\
\hline Myrcia ramulosa............ & 11 & 0.44 & 0.03 & 1.01 & 1.48 & 0.47 \\
\hline Ocotea odorifera.......... & 4 & 0.16 & 0.68 & 0.51 & 1.35 & 0.84 \\
\hline Cordia ecalyculata........ & 8 & 0.32 & 0.01 & 0.88 & 1.22 & 0.33 \\
\hline Esenbeckia febrifuga....... & 8 & 0.32 & 0.01 & 0.88 & 1.22 & 0.33 \\
\hline Trichilia pallida.......... & 7 & 0.28 & 0.03 & 0.88 & 1.20 & 0.31 \\
\hline 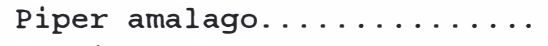 & 7 & 0.28 & 0.05 & 0.76 & 1.08 & 0.32 \\
\hline 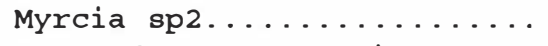 & 7 & 0.28 & 0.01 & 0.76 & 1.05 & 0.29 \\
\hline Nectandra megapotanica..... & 6 & 0.24 & 0.02 & 0.76 & 1.02 & 0.26 \\
\hline Luetzelburguia guaissara... & 1 & 0.04 & 0.80 & 0.13 & 0.96 & 0.84 \\
\hline Coutarea hexandra.......... & 7 & 0.28 & 0.00 & 0.63 & 0.91 & 0.28 \\
\hline Eugenia aff. ligustrina.... & 6 & 0.24 & 0.03 & 0.63 & 0.90 & 0.27 \\
\hline Psychotria sessilis....... & 6 & 0.24 & 0.01 & 0.63 & 0.88 & 0.25 \\
\hline Cabralea canjerana......... & 2 & 0.08 & 0.52 & 0.25 & 0.85 & 0.60 \\
\hline Hybanthus atropurpureus.... & 5 & 0.20 & 0.01 & 0.63 & 0.84 & 0.21 \\
\hline 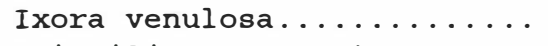 & 5 & 0.20 & 0.01 & 0.63 & 0.84 & 0.21 \\
\hline Trichilia clausseni........ & 4 & 0.16 & 0.04 & 0.51 & 0.70 & 0.19 \\
\hline Ocotea beulahiae.......... & 4 & 0.16 & 0.01 & 0.51 & 0.67 & 0.17 \\
\hline Myrciaria sp2 $\ldots \ldots \ldots \ldots$ & 4 & 0.16 & 0.00 & 0.51 & 0.67 & 0.16 \\
\hline Holocalyx balansae......... & 4 & 0.16 & 0.00 & 0.51 & 0.67 & 0.16 \\
\hline Eugenia cf. Cambucarana.... & 5 & 0.20 & 0.00 & 0.38 & 0.58 & 0.20 \\
\hline Savia dyctiocarpa......... & 4 & 0.16 & 0.01 & 0.38 & 0.55 & 0.17 \\
\hline Calypthrantes concinna..... & 4 & 0.16 & 0.01 & 0.38 & 0.54 & 0.17 \\
\hline
\end{tabular}


Cont.

\begin{tabular}{|c|c|c|c|c|c|c|}
\hline espécie & No. Ind & Dens.Re & 1 Dom. & I Freq.Re & el & \\
\hline Calypthrantes clusiaefolia.. & 4 & 0.16 & 0.00 & 0.38 & 0.54 & 0.16 \\
\hline Psychotria hoffmanseggiana.. & 3 & 0.12 & 0.00 & 0.38 & 0.50 & 0.12 \\
\hline Psychotria nuda............ & 3 & 0.12 & 0.00 & 0.38 & 0.50 & 0.12 \\
\hline styrax pohlii........... & 3 & 0.12 & 0.01 & 0.25 & 0.38 & 0.13 \\
\hline Astronium graveolens....... & 3 & 0.12 & 0.00 & 0.25 & 0.38 & 0.12 \\
\hline Agonandra englerii........ & 2 & 0.08 & 0.04 & 0.25 & 0.37 & 0.12 \\
\hline Psychotria mapourioides.... & 2 & 0.08 & 0.01 & 0.25 & 0.34 & 0.09 \\
\hline Allophylus edulis.......... & 2 & 0.08 & 0.01 & 0.25 & 0.34 & 0.09 \\
\hline 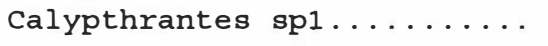 & 2 & 0.08 & 0.01 & 0.25 & 0.34 & 0.09 \\
\hline Cariniana estrellensis..... & 2 & 0.08 & 0.00 & 0.25 & 0.34 & 0.08 \\
\hline Guatteria nigrescens....... & 2 & 0.08 & 0.00 & 0.25 & 0.34 & 0.08 \\
\hline Protium cf. heptaphyllum... & 2 & 0.08 & 0.00 & 0.25 & 0.33 & 0.08 \\
\hline Lacistema hasslerianum..... & 2 & 0.08 & 0.00 & 0.25 & 0.33 & 0.08 \\
\hline Sorocea bonplandii........ & 2 & 0.08 & 0.00 & 0.25 & 0.33 & 0.08 \\
\hline Cupania vernalis.......... & 2 & 0.08 & 0.00 & 0.25 & 0.33 & 0.08 \\
\hline Mollinedia widgrenii....... & 1 & 0.04 & 0.07 & 0.13 & 0.24 & 0.11 \\
\hline Centrolobium tomentosum..... & 1 & 0.04 & 0.04 & 0.13 & 0.20 & 0.08 \\
\hline 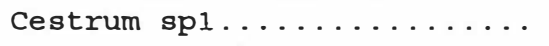 & 1 & 0.04 & 0.03 & 0.13 & 0.19 & 0.07 \\
\hline Ocotea corymbosa........... & 1 & 0.04 & 0.01 & 0.13 & 0.18 & 0.05 \\
\hline 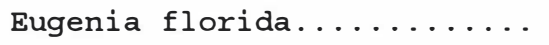 & 1 & 0.04 & 0.01 & 0.13 & 0.18 & 0.05 \\
\hline Zanthoxylum monoginum...... & 1 & 0.04 & 0.01 & 0.13 & 0.17 & 0.05 \\
\hline 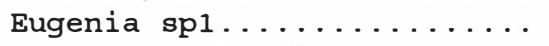 & 1 & 0.04 & 0.01 & 0.13 & 0.17 & 0.05 \\
\hline Carica quercifolia......... & 1 & 0.04 & 0.01 & 0.13 & 0.17 & 0.05 \\
\hline Alchornea glandulosa....... & 1 & 0.04 & 0.01 & 0.13 & 0.17 & 0.05 \\
\hline Rhamnidium elaeocarpum..... & 1 & 0.04 & 0.00 & 0.13 & 0.17 & 0.04 \\
\hline Acacia polyphylla......... & 1 & 0.04 & 0.00 & 0.13 & 0.17 & 0.04 \\
\hline Citronella paniculata...... & 1 & 0.04 & 0.00 & 0.13 & 0.17 & 0.04 \\
\hline Guapira opposita.......... & 1 & 0.04 & 0.00 & 0.13 & 0.17 & 0.04 \\
\hline Andira fraxinifolia........ & 1 & 0.04 & 0.00 & 0.13 & 0.17 & 0.04 \\
\hline Amaioua guianensis........ & 1 & 0.04 & 0.00 & 0.13 & 0.17 & 0.04 \\
\hline sloanea monosperma........ & 1 & 0.04 & 0.00 & 0.13 & 0.17 & 0.04 \\
\hline Aloysia virgata........... & 1 & 0.04 & 0.00 & 0.13 & 0.17 & 0.04 \\
\hline Miconia discolor........... & 1 & 0.04 & 0.00 & 0.13 & 0.17 & 0.04 \\
\hline Picramnia warmingiana...... & 1 & 0.04 & 0.00 & 0.13 & 0.17 & 0.04 \\
\hline Ardisia glauciflora........ & 1 & 0.04 & 0.00 & 0.13 & 0.17 & 0.04 \\
\hline 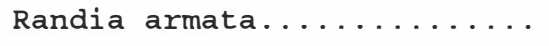 & 1 & 0.04 & 0.00 & 0.13 & 0.17 & 0.04 \\
\hline Campomanesia spl......... & 1 & 0.04 & 0.00 & 0.13 & 0.17 & 0.04 \\
\hline Merostachys riedeliana..... & 1 & 0.04 & 0.00 & 0.13 & 0.17 & 0.04 \\
\hline Pachystroma longifolium.... & 1 & 0.04 & 0.00 & 0.13 & 0.17 & 0.04 \\
\hline Rollinia sylvatica........ & 1 & 0.04 & 0.00 & 0.13 & 0.17 & 0.04 \\
\hline Lamanonia ternata......... & 1 & 0.04 & 0.00 & 0.13 & 0.17 & 0.04 \\
\hline Cestrum schlechtendalii... & 1 & 0.04 & 0.00 & 0.13 & 0.17 & 0.04 \\
\hline Matayba guianensis......... & 1 & 0.04 & 0.00 & 0.13 & 0.17 & 0.04 \\
\hline Myroxylon peruiferum....... & 1 & 0.04 & 0.00 & 0.13 & 0.17 & 0.04 \\
\hline 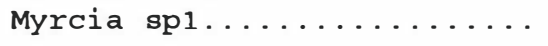 & 1 & 0.04 & 0.00 & 0.13 & 0.17 & 0.04 \\
\hline 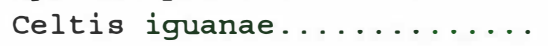 & 1 & 0.04 & 0.00 & 0.13 & 0.17 & 0.04 \\
\hline
\end{tabular}


Parâmetros fitossociológicos das famílias amostradas em trechos da unidade ecológica "Maciço de Diatencpteryx sorbifolia Radlk." na Reserva Municipal de Santa Genebra, Município de Campinas, SP. $\mathrm{N}^{\circ}$ Ind. = número de indivíduos; $\mathrm{N}^{\circ} . \mathrm{Spp}=$ número de espécies; Dens.Rel. = densidade relativa (\%); Dom.Rel. = dominância relativa (\%); Freq. Rel. = frequência relativa (\%); IVI = índice de valor de importância; IVC = índice de valor de cobertura.

\begin{tabular}{|c|c|c|c|c|c|c|c|}
\hline família & No. Ind I & No.Spp & Dens.Re & Dom.Rel & Freq.Re & IVI & IVC \\
\hline Euphorbiaceae... & 1148 & 5 & 45.83 & 4.46 & 13.30 & 63.59 & 50.29 \\
\hline Rutaceae...... & 371 & 5 & 14.81 & 9.85 & 10.82 & 35.47 & 24.66 \\
\hline Rubiaceae. & 265 & 12 & 10.58 & 0.46 & 10.99 & 22.03 & 11.04 \\
\hline Myrtaceae...... & 203 & 16 & 8.10 & 2.67 & 11.88 & 22.65 & 10.77 \\
\hline Apocynaceae.... & 160 & 1 & 6.39 & 0.26 & 10.99 & 17.64 & 6.65 \\
\hline Meliaceae....... & 124 & 5 & 4.95 & 0.88 & 10.11 & 15.93 & 5.83 \\
\hline Sapindaceae.... & 68 & 4 & 2.71 & 61.62 & 7.62 & 71.96 & 64.34 \\
\hline Fabaceae........ & 26 & 5 & 1.04 & 8.93 & 3.37 & 13.33 & 9.96 \\
\hline Polygalaceae.... & 21 & 1 & 0.84 & 0.01 & 2.66 & 3.50 & 0.85 \\
\hline Lauraceae...... & 17 & 5 & 0.68 & 2.36 & 2.84 & 5.87 & 3.04 \\
\hline Monimiaceae.... & 15 & 2 & 0.60 & 0.16 & 1.77 & 2.53 & 0.75 \\
\hline Sapotaceae...... & 14 & 1 & 0.56 & 0.02 & 2.13 & 2.71 & 0.58 \\
\hline Mimosaceae..... & 13 & 2 & 0.52 & 0.01 & 1.60 & 2.13 & 0.53 \\
\hline Boraginaceae... & 8 & 1 & 0.32 & 0.01 & 1.24 & 1.57 & 0.33 \\
\hline Piperaceae..... & 7 & 1 & 0.28 & 0.05 & 1.06 & 1.39 & 0.32 \\
\hline Caesalpiniaceae. & 6 & 2 & 0.24 & 3.46 & 1.06 & 4.76 & 3.70 \\
\hline Violaceae...... & 5 & 1 & 0.20 & 0.01 & 0.89 & 1.10 & 0.21 \\
\hline Annonaceae..... & 3 & 2 & 0.12 & 0.00 & 0.53 & 0.65 & 0.12 \\
\hline Styracaceae.... & 3 & 1 & 0.12 & 0.01 & 0.35 & 0.49 & 0.13 \\
\hline Anacardiaceae... & 3 & 1 & 0.12 & 0.00 & 0.35 & 0.48 & 0.12 \\
\hline Solanacea...... & 2 & 2 & 0.08 & 0.03 & 0.35 & 0.46 & 0.11 \\
\hline Lecythidaceae... & 2 & 1 & 0.08 & 0.00 & 0.35 & 0.44 & 0.08 \\
\hline Opiliaceae..... & 2 & 1 & 0.08 & 0.04 & 0.35 & 0.47 & 0.12 \\
\hline Burseraceae.... & 2 & 1 & 0.08 & 0.00 & 0.35 & 0.44 & 0.08 \\
\hline Lacistemataceae. & 2 & 1 & 0.08 & 0.00 & 0.35 & 0.44 & 0.08 \\
\hline Moraceae....... & 2 & 1 & 0.08 & 0.00 & 0.35 & 0.44 & 0.08 \\
\hline Simaroubaceae... & 1 & 1 & 0.04 & 0.00 & 0.18 & 0.22 & 0.04 \\
\hline Melastomataceae. & 1 & 1 & 0.04 & 0.00 & 0.18 & 0.22 & 0.04 \\
\hline Caricaceae..... & 1 & 1 & 0.04 & 0.01 & 0.18 & 0.22 & 0.05 \\
\hline Rhamnaceae..... & 1 & 1 & 0.04 & 0.00 & 0.18 & 0.22 & 0.04 \\
\hline Poaceae........ & 1 & 1 & 0.04 & 0.00 & 0.18 & 0.22 & 0.0 \\
\hline Icacinaceae.... & 1 & 1 & 0.04 & 0.00 & 0.18 & 0.22 & 0.0 \\
\hline Nyctaginacea.... & 1 & 1 & 0.04 & 0.00 & 0.18 & 0.22 & 0.0 \\
\hline Myrsinaceae..... & 1 & 1 & 0.04 & 0.00 & 0.18 & 0.22 & 0.0 \\
\hline Verbenaceae..... & 1 & 1 & 0.04 & 0.00 & 0.18 & 0.22 & 0.0 \\
\hline Ulmaceae....... & 1 & 1 & 0.04 & 0.00 & 0.18 & 0.22 & 0.0 \\
\hline Tiliaceae.... & 1 & 1 & 0.04 & 4.67 & 0.18 & 4.88 & 4.7 \\
\hline Cunoniaceae..... & 1 & 1 & 0.04 & 0.00 & 0.18 & 0.22 & 0.0 \\
\hline Elaeocarpaceae.. & 1 & 1 & 0.04 & 0.00 & 0.18 & 0.22 & \\
\hline
\end{tabular}




\section{REFERÊNCIAS BIBLIOGRÁFICAS}

ANDRADE-LIMA, D. de. Vegetação. In: FUNDAÇÃO INSTITUTO BRASILEIRO DE GEOGRAFIA E ESTATÍSTICA, Atlas nacional do Brasil. Rio de Janeiro, 1966. Folha II - 11.

ARIMA, L.I.A.; OLIVEIRA, L.G.; BARROS, L.T.L.P. et al. Estudo da Vegetação Natural/Uso do Solo como Subsídio ao Zoneamento Sócio-Econômico Ecológico do Município de Jaurú - MT. In: SIMPÓSIO BRASILEIRO DE SENSORIAMENTO REMOTO, 7., Curitiba, 1993. Anais. Curitiba: INPE, 1993. p. 06-14.

ARONOFF, S. The map accuracy report: a user's view. Photogrammetric

Engineering \& Remote Sensing, v.48, n.8, p. 1309-1312, 1982b.

ARONOFF, S. Geografic information systems: a management perspective. Ottawa: WDL, 1989. 294p.

BAITELlO, J. B.; PASTORE, J. A.; AGUIAR, O. T. de,; SERIO, E C.; SILVA, C. E. F. A Vegetação Arbórea do Parque Estadual do Morro do Diabo, Mun. de Teodoro Sampaio, Estado de São Paulo. Acta Botânica Brasílica, v.1 p. 221-230, 1988. Suplemento.

BAITELlO, J.B.: PASTORE, J.A.: AGUIAR, O.T.: ROCHA, F.T.; ESTEVES, R. Florística e Fitossociologia do Estrato Arbóreo de um Trecho da Serra da Cantareira (Núcleo Pinheirinho), SP. In: CONGRESSO NACIONAL SOBRE ESSÊNCIAS NATIVAS, 2. São Paulo, 1992. Anais. São Paulo: Instituto Florestal, 1992. v.1, p.291-297.

BAUER, M.E.; BURK, T.E.; EK, A.R.; COPPIN, P.R.; LIME, S.D.; WALSH, T.A.; WALTERS, D.K.; BEFORT, W.; HEINZEN, D.F. Satellite inventory of Minesota forest resources. Photogrammetric Engineering \& Remote Sensing, v.60, n.3, p.287-298, 1994. 
BENSON, A.S.; DRAEGER, W.C.; PETTINGER, L.R. Ground data collection and use. Photogrammetric Engineering \& Remote Sensing, v.37, p.1159-1167, 1971.

BERNACCI, L. C. Estudo florístico e fitossociológico de uma floresta no município de Campinas, com ênfase nos componentes herbáceo e arbustivo. Campinas, 1992. 147 p. Dissertação (M.S.) - Universidade Estadual de campinas.

BERTONI, J.E. Composição florística e estrutura fitossociológica de uma floresta no interior do Estado de São Paulo: Reserva Estadual de Porto Ferreira". Campinas, 1984. 196p. Dissertação (M.S.) - Universidade Estadual de Campinas.

BERTONI, J.E.A.; MARTINS, F.R.; MORAES, J.L.; SHEPHERD, G.J. Composição florística e estrutura fitossociológica do Parque Estadual de Vaçununga, Santa Rita do Passa Quatro, SP - Gleba Praxedes. Boletim Técnico do Instituto Florestal, v. 42 p.149-170, 1988.

BITENCOURT, M.D.; MESQUITA Jr, H. N.; MANTOVANI, W.; BATALHA, M.A.; PIVELLO, V.R. Identificação de fisionomias de cerrado com imagem índice de vegetação. In: CONGRESSO DE ECOLOGIA DO BRASIL, 3. Brasília, 1997. Contribuição ao conhecimento ecológico do Cerrado. Brasília: Departamento de Ecologia, Universidade de Brasília, 1997. P. 316-320.

BRONDIZIO, E.S.; MORAN, E.F.; MAUSEL, P.; WU, Y. Dinâmica na Vegetação do Baixo Amazonas: Análise Temporal do Uso da Terra Integrando Imagens Landsat TM, Levantamentos Florístico e Etnográfico. In: SIMPÓSIO BRASILEIRO DE SENSORIAMENTO REMOTO, 7., Curitiba, 1993. Anais. Curitiba: INPE, 1993. p. 38-46.

CARDOSO-LEITE, E. Ecologia de um fragmento florestal em São Roque, SP: florística, fitossociologia e silvigênese. Campinas, 1995. Dissertação (M.S.) Universidade Estadual de Campinas.

CASTELLANI, T.T;; STUBBLEBINE, W.H. Sucessão secundária inicial em mata tropical mesófila, após perturbação por fogo. Revista Brasileira de Botânica, v.16, p. $181-204,1993$. 
CATHARINO, E.L.M. Estudos fisionômico-florísticos e fitossociológico em matas residuais secundárias do município de Piracicaba, SP. Campinas, 1989a. 181p. Dissertação (M.S.) - Universidade Estadual de Campinas.

CAVASSAN, O.; CESAR, O.; MARTINS, F.R. Fitossociologia da vegetação arbórea da Reserva Estadual de Bauru, Estado de São Paulo. Revista Brasileira de Botânica, v.7, p. 91-106, 1984.

CAVASSAN, O.; MARTINS, F.R. Estudos florísticos e fitossociológicos em áreas de vegetação nativa no município de Bauru, SP. Salusvita,. v.8, n1, p. 41-47, 1990.

CESAR, O. Composição florística, fitossociologia e ciclagem de nutrientes em matas mesófilas semidecíduas. (Fazenda Barreiro Rico, Município de Anhembi, S.P.) Rio Claro, 1988. Tese (Livre-Docência) - Universidade Estadual Paulista.

CHAVEZ, P.S. Comparason of spatial variability in visible and near infrared spectral images, Photogrammetric Engineering \& Remote Sensing, v.58, n.7, p. 957-964. 1992.

CHEN, S.C. Informações espectrais e texturais de vegetação da região amazônica a partir de dados do sensor TM do satélite Landsat. São Paulo, 1996. Tese (Doutorado) Departamento de Geografia - FFLCH - Universidade de São Paulo.

COHEN, J. A coefficient of agreement for nominal scales, Educational and Psychological Mensurament, v. 20, n.1, p. 37-46p, 1960.

CONGALTON, R.G. A review of assessing the accuracy of classifications of remotely sensed data. Remote Sensing of Environment, v.37, n.1, p.35-46, 1991.

CONGALTON, R.G.; GREEN, K.; TEPLY, J. Mapping old growth forests on National Forest and Park lands in the Pacific Northwest from remotely sensed data. Photogrammetric Engineering \& Remote Sensing, v.59, n.4, p.529-535, 1993. CONSEMA (CONSELHO ESTADUAL DO MEIO AMBIENTE). Áreas naturais. São Paulo, 1985.

CREPANI, E. Principios básicos de Sensoriamento Remoto. São José dos Campos. INPE, 1983. 45p. 
CRONQUIST, A. An integrated system of classification of flowering plants. New York: Columbia University Press, 1981. 1262p.

CRÓSTA, A.P. Processamento digital de imagens de sensoriamento remoto. Campinas: UNICAMP, 1992. 170 p.

DURIGAN, G.; LEITÃO FILHO, H.F. Florística e fitossociologia de matas ciliares do oeste paulista. Revista do Instituto Florestal, v.7, n.1, p. 197-239. 1995.

EASTMAN, J.R. IDRISI: user's guide. Worcester: Clark University, Graduate School of Geography, 1992. 178p.

FEFILI, J.M. Deteminação de padrões de distribuição de espécies em uma mata de galeria no Brasil central, com a utilização de técnicas de análise multivariada. Bol. Herb. Ezechias Paulo Heringer, v.2, p. 35-48. 1998.

FRANKLIN, S.E.; TITUS, B.D.; GILLESPIE. Remote Sensing of Vegetation Cover at Forest Regeneration Sites. Global Ecology and Biogeography Letters, v.4, p. 4046. 1994.

FUNDAÇÃO INSTITUTO BRASILEIRO DE GEOGRAFIA E ESTATÍSTICA - IBGE. Manual Técnico da Vegetação Brasileria. Rio de Janeiro, 1992. 92 p. (Série Manuais Técnicos em Geociências, 1).

GABRIEL, J.C.L. Composição Florística e Estrutura Fitossociológica do Estado Arbóreo de Mata Mesófila Semidecídua de Encosta no Município de Botucatu. Rio Claro, 1990. 198 p. Dissertação (M.S.) - Instituto de Biociências - Campus de Rio Claro, Universidade Estadual Paulista "Júlio de Mesquita Filho".

GALETTI, M.; PEDRONI, F. Seasonal diet of capuchin monkeys (Cebus apella) in a semideciduous forest in south-east Brazil. Journal of Tropical Ecology, v.10, p. 27 39. 1994.

GANDOLFI, S. Estudo florístico e fitossociológico de uma floresta Residual na Área do Aeroporto Internacional de São Paulo, município de Guarulhos, SP. Campinas, 1991. 232p. Dissertação (M.S.) - Instituto de Biociências - Universidade Estadual de Campinas. 
GANDOLFI, S. Aspectos da sucessão de uma floresta mesófila semidecídua, Reserva de Santa Genebra, Campinas, SP. Campinas, 1995. Relatório final do projeto de pesquisa financiado pela FAPESP - Universidade Estadual de Campinas, SP.

GANDOLFI, S. Alguns aspectos da história natural de uma floresta estacional semidecidual no município de Campinas (São Paulo, Brasil). Campinas, 1999 (Prébanca). Tese (Doutorado) - Instituto de Biociências, Universidade Estadual de Campinas.

GAUCH, H.G. Hierarchical classification of community data. Journal of Ecology, v.69, p. 135 - 152. 1981.

GRAHAM L.A.; GALLION, C. Image Processing Under Windows NT: A Comparative Review. GIS World Inc, p. 36-44. 1996.

GROMBONE, M.T.; BERNACCI, L.C.; MEIRA NETO, J.A.A.; TAMASHIRO, J.Y.; LEITÃO FILHO, H.F. Estrutura Fitossociológica da Floresta Semidecídua de Altitude do Parque Municipal de Grota Funda (Atibaia - Estado de São Paulo). Acta Botânica Brasílica, v. 4, n.2, p. 47-64, 1990.

HARALICK, R.M. Statistical and structural approaches to texture. Proc. IEEE, v.67, n.5, p.786-804. 1979.

HARRIS, R. Spectral and spatial image processing for remote sensing. Internacional Journal of Remote Sensing, v.1, n.4, p.361 - 375. 1980.

HAY, A.M. Sampling designs to test land-use map accuracy. Photogrammetric Engineering \& Remote Sensing, v.45, n.4, p.529-533, 1979.

HILL, M.O. Twinspan-a fortran program for arranging multivariate data in na ordered two-way table by classification of the individuals and attributes. Ithaca, NY: Ecology ans Systematic, Cornell University. 1979.

HIXSON, M.M.; SCHOLZ, D.; FUHS, N.; AKIYAMA, T. Evoluation of several schemes for classification of remotely sensed data. Photogrammetric Engineering \& Remote Sensing, v.46, n.12, p. 1547 - 1553, 1980.

HUECK, K. As florestas da América do Sul. Trad. de H. Reichardt. São Paulo: Editora Polígono; Editora da Universidade de Brasília, 1972. 466p. 
IVANAUSKAS, N.M.; RODRIGUES, R.R.; NAVE, A.G. Aspectos Ecológicos de uma Mata de Brejo em Itatinga - SP: Florística, Fitossociologia e Seletividade de Espécies. Revista Brasileira de Botânica, v.20, n.2, p. 139-153. 1997.

JANSSEN, L.L.F.; VAN DER WEL, F.J.M. Accuracy assessment of satellite derived land-cover data: a review. Photogrammetric Engineering \& Remote Sensing, v.60, n.4, p.419-426. 1994.

JOLY, A.B. Botânica: chaves de identificação das famílias de plantas vasculares que ocorrem no Brasil, baseadas em chaves de Franz Thonner. 3.ed. São Paulo: Editora Nacional, 1977. 159p.

JORGE, L.A.B. Estudo de fragmentos de florestas naturais na região de Botucatu, SP, através de técnicas de geoprocessamento. Rio Claro, 1995. 109p. Dissertação (M.S.) Instituto de Geociências e Ciências exatas - Universidade Estadual Paulista.

KOEPPEN, W. Carta climática do Estado de São Paulo. São Paulo: Secretaria da Agricultura. 1945- 1962.

KOFFLER, N.F.; CAVALLI, A.C.; CHIARINI, J.V.; NOGUEIRA, F.P. Inventário Canavieiro com Auxílio de Fotografias Aéreas. Boletim Técnico Planalsucar, v.1, n.2, p.3-38. 1979.

KOTCHEKOFF-HENRIQUES, O. Estudo Florístico e Fitossociológico em uma Mata Mesófila Semidecídua da Serra do Itaqueri, Itirapina, Estado de São Paulo, Brasil. Revista Brasileira de Botânica, v. 54, n. 3, p 477 - 487. 1994.

KOTCHETKOFF-HENRIQUES, O.; JOLY,C.A. Estudo florístico e fitossociológico em uma mata mesófila semidecídua na Serra do Itaqueri, Itirapina, SP. Revista Brasileira de Biologia. v. 53, n. 3, p. 477-487. 1994.

KRONKA, F.J.N.; MATSUKUMA, C.K.; NALON, M.A.; CALI, I.H.D et al. Inventário Florestal do Estado de São Paulo, Instituto Florestal, CITDPA, Secretaria de meio Ambiente Governo do Estado de São Paulo. 1993.

LANDGREB, D.A.. The development of a spectral-spatial classification for earth observational data, Pattern Recognition, v.12, p. 165-175. 1980. 
LATTY, R.S.; NELSON, R.; MARKHAM, B.L.; WILLIAM, D.; TOLL, D.; IRONS, J.R. Performance comparisons between information extraction techniques using variable spatial resolution data. Photogrammetric Engineering \& Remote Sensing, v. 5, p. $11459-1470.1985$.

LEITÃO-FILHO, H.F. Aspectos taxonômicos das florestas do Estado de São Paulo. In: CONGRESSO NACIONAL SOBRE ESSÊNCIAS NATIVAS, 1. Campos do Jordão, 1982. Anais. São Paulo: Silvicultura em São Paulo, 1982. v. 16, n. 1, p. 197 - 206, 1982.

LEITÃO-FILHO, H.F. Considerações sobre a florística de florestas tropicais e subtropicais do Brasil. Piracicaba, SP, IPEF, v.1, p. 35. 1987.

LEITÃO-FILHO, H.F. A Vegetação da Reserva de Santa Genebra. In: MORELLATO, P.C.; LEITÃO FILHO, H.F. Ecologia e preservação de uma floresta tropical urbana: Reserva de Santa Genebra. Campinas: Editora da Universidade Estadual de Campinas, 1995. cap. 2, p. 19-29.

LILLESAND, T.M.; KIEFER, R.W. Remote sensing and image interpretation. New York: John Wiley, 750p. 1994.

LIMA, W. P. Função hidrológica da mata ciliar. In: SMPÓSIO SOBRE MATA CILIAR. São Paulo, 1989. Anais. São Paulo: Instituto de Botânica, 1989. p. 25-42.

LOCH, R.E.N.; SILVA, O.G. Avaliação dos Danos à Paisagem na "Capital Brasileira do Carvão"- Cricíuma- SC. In: SIMPÓSIO BRASILEIRO DE SENSORIAMENTO REMOTO, 7., Curitiba, 1993. Anais. Curitiba: INPE, 1993. p. 171-180.

MARCEAU, D.J.; HOWARTH, P.J.; DUBOIS, J.M.; GRATTON, D.J. Evaluation of the grey-level co-ocorrence matrix method for land-cover classification using SPOT imagery, IEEE Transactions on Geoscience \& Remote Sensing, v.28, n.4, p. 513 519. 1990.

MARTINS, E R. O método de quadrantes e fitossociologia de uma floresta residual do interior do Estado de São Paulo. São Paulo, 1979. 239 p. Tese (Doutorado) Instituto de Biociências - Universidade de São Paulo 
MARTINS, F.R. Estrutura de uma mata mesófila. Campinas: Ed. Universidade de Campinas, Campinas. 1993. 246 p.

MARTINS, V.S. Regeneração natural e produção de serapilheira em clareiras da Reserva Municipal de Santa Genebra, Campinas, SP. Campinas, 1999. Tese (Doutorado) -Instituto de Biologia, Universidade Estadual de Campinas.

MATHER, P.M. Computer processing of remotely sensed images. Chicester: John Wiley, 1987. 352p.

MATTHES, L.A.F. Composição florística, estrutura e fenologia de uma floresta residual do planalto paulista: Bosque dos Jequitibás (Campinas, SP). Campinas, 1980. 209p. Dissertação (M.S.) - Instituto de Biologia, Universidade Estadual de Campinas.

MATTHES, L.A.F.; LEITÃO-FILHO, H.F.; MARTIN, F.R. Composição florística e estrutura fitossociológica do estrato arbóreo, Bosque dos Jequitibás, Campinas. In: CONGRESSO DA SOCIEDADE BOTÂNICA DE SÃO PAULO, 5. São Paulo, 1988. Anais. São Paulo: 1988. p.55-76.

MATTHES, L.A.F. Dinâmica da sucessão secundária em mata, após a ocorrência de fogo, Santa Genebra, Campinas, São Paulo. Campinas, 1991. Tese (Doutorado) Instituto de Biologia, Universidade Estadual de Campinas.

MAUSEL, P.; WU Y.; LI Y.; MORAN E.; BRONDIZIO E. Spectral identification of sucessional stages following deforestation in the Amazon. Geocarto International, v.8, n.4, p. 1-11. 1993

MEIRA NETO, A.A.; BERNACCI, L.C.; GRAMBONE, M.T.; TAMASHIRO, J.Y.; LEITÃO FILHO, H.F. Composição florística da floresta semi decídua de altitude do Parque Municiapl da Grota (Atibaia, estado de São Paulo), Floristic composition of the semi deciduos montain forest of the Grota Funda municipal park (Atibaia, SP), Acta Botânica Brasílica, v.3, n.2, p.51-74. 1989.

METZGER, J.P.; BERNACCI, L.C.; GOLDENBERG, R. Pattern of tree species diversity in riparian forest fragments of different widths (SE Brazil). Plant Ecology, v. 133, p.135-152. 1997. 
MIRANDA, J.R.; MANTOVANI, L.E.; SANTOS, R.Z. dos; COUTINHO, A.C.; MANGABEIRA, J.A.C. Mapeamento ecológico da Reserva da Serra do Lajeado (TO). Relatório Técnico. Campinas, SP: EMBRAPA-NMA, 68p. jan. 1992.

MORAN, E.F.; BRONDIZIO, E.; MAUSEL, P.; LI, Y.H. Assinaturas Espectrais

Diferenciando Etapas de Sucessão Secundária no Leste Amazônico. In: SIMPÓSIO BRASILEIRO DE SENSORIAMENTO REMOTO, 7., Curitiba, 1993. Anais. Curitiba: INPE, 1993. p. 202-209.

MORAN, E.F.; BRONDIZIO, E.; MAUSEL, P.;WU, Y. Integrating Amazonian Vegetation, Land-use, and Satélite Data. BioScience, v. 44, n.5. 1994.

MORELLATO , P.C.; LEITÃO FILHO, H.F. (orgs). Ecologia e preservação de uma floresta tropical urbana: Reserva de Santa Genebra. Editora da Universidade Estadual de Campinas, Campinas, SP. 1995.

MORELLATO, L.P.C. Estudo da fenologia de árvores, arbustos e lianas de uma floresta semidecídua no sudeste do Brasil. Campinas, 1991. 176 p. Tese (Doutorado) Instituto de Biologia, Universidade Estadual de Campinas.

MUELLER DOMBOIS, D.; ELLEMBERG.H. Aims and methods of vegetation ecology. New York: John Wiley, 1974.574p.

NASTRI, V.D.F.; CATHARINO E.L.M.; ROSSI, L. et al. Estudos fitossociológicos em uma área do Instituto de Botânica de São Paulo utilizados em programas de educação ambiental. In: CONGRESSO NACIONAL SOBRE ESSÊNCIAS NATIVAS, 2. São Paulo, 1992. Anais. São Paulo: Instituto Florestal, 1992. v.1, p. 219-225.

NAVE, A.G. Chave de identificação baseada em caracteres vegetativos de espécies arbustivo-arbóreas nativas de mata de Planalto no Estado de São Paulo. Relatório de residência agronômica da Escola Superior de Agricultura Luiz de Queiroz, Universidade de São Paulo. 1994.

NICOLINI, E.M. Composição florística e estrutura fitossociológica em mata mesófila semidecídua no município de Jaú, SP. Rio Claro, 1990. 179 p. Dissertação (M.S.) Instituto de Biociências - Universidade Estadual Paulista. 
NOVO, E.M.L.M. Sensoriamento remoto: princípios e aplicações. São Paulo: Edgard Blücher, 1989.

Ó-FILHO, E.F. do; MASCARENHAS, N.D.A.; SONNENBURG, C.R. Classificações de imagens multiespectrais através de características de texturas, Relatório INPE1734-RPE/137, São José dos Campos, SP. 1980.

OLDEMAN, R.A.A. Queques aspects quantifiables de l'arborigenèse et de la sylvigenèse. Oecol. Plan, v.14, n.3, p. 289-312. 1979.

OLIVEIRA, R.E. Aspectos da dinâmica de um fragmento florestal em Piracicaba, SP: Silvegênese e ciclagem de nutrientes. Piracicaba. 1997. Dissertação (Mestrado) Escola Superior de Agricultura Luiz de Queiroz, Universidade de São Paulo.

OLIVEIRA-FILHO, A.T.; RATTHER, J.A. A study of the origin of Central Brazilian forests by the analysis of plants species distribution patterns. Eddinb. J. Bot., v.52, n.2, p. 141-194. 1995.

PAGANO, S.N.; LEITÃO-FILHO, H.E. Composição florística do estrato arbóreo de mata mesófila semidecídua, no município de Rio Claro (Estado de São Paulo). Revista Brasileira de Botânica, v. 10, p. 37-47. 1987.

PASTORE, J.A.: AGUIAR, O.T.: ESTEVES, R.; SILVA, C.A.F. Flora arbóreaarbustiva do Parque Chico Mendes, município de São Bernado do Campo, SP. In: CONGRESSO NACIONAL SOBRE ESSÊNCIAS NATIVAS, 2. São Paulo, 1992. Anais. São Paulo: Instituto Florestal, 1992. v.1, p. 269-273.

PEDLEY, M.I.; CURRAN, P.J. Per-field classification: an example using SPOT HRV imagery, International Journal of Remote Sensing, v.12, n.11, p. 2181-2192. 1991.

PEDRONI, F. Ecologia da copaíba (Ccpa,fera langsdor,jfi Desf. - Caesalpiniaceae) na Reserva Municipal de Santa Genebra, Campinas, SP. Campinas, 1994. Dissertação (M.S.) Universidade Estadual de Campinas.

PEREIRA, M.N.; KURHKDJAN, M.L.N.O.; FORESTI, C. Cobertura e uso da terra através de sensoriamento remoto. São José dos Campos: INPE, 1989.

PINTO, M.M. Levantamento fitossociológico de uma mata residual situada no Campus de Jaboticabal da Universidade Estadual Paulista. Jaboticabal, 1989. 114 p. 
Dissertação (M.S.) - Faculdade de Ciências Agrárias e Veterinárias - Universidade Estadual Paulista "Júlio de Mesquita Filho".

PIVELLO, V.R.; PECCININI, A.A.; CARVALHO, V.M.; LOPES, P.F. O uso do solo na região da reserva biológica do cerrado de Emas (Pirassununga, S.P.) e seu atual papel como unidade de conservação. In: CONGRESSO DE ECOLOGIA DO BRASIL, 3. Brasília, 1997. Contribuição ao conhecimento ecológico do Cerrado. Brasília: Depto. de Ecologia - Universidade de Brasília, 1997.

PRENTICE, I.C. Vegetation analysis and order invariant gradient models. Vegetatio, v. 42, p. 27-34p. 1980.

QUINTANILHA, J.A. Processamento de imagens digitais. In: SIMPÓSIO BRASILEIRO DE GEOPROCESSAMENTO, 1., São Paulo, 1990. Anais. São Paulo: EPUSP. 1990. p. 37-52.

REICHMAMM NETO, F. Revegetalização de áreas marginais e reservatórios de hidroelétricas. In: CONGRESSO FLORESTAL BRASILEIRO, 4., Manaus, 1978. Anais. São Paulo: Sociedade Brasileira de Silvicultura, 1978. p. 215-217.

RICHARDS, P.W. The tropical rain forest an ecological study. Cambridge: Cambridge University Press, 1966. 450 p.

RODRIGUES, R.R. Levantamento florístico e fitossociológico das matas da Serra do Japi, Jundiaí, SP. Campinas, 1986. 198 p. Dissertação (M.S.) - Instituto de Biologia, Universidade Estadual de Campinas.

RODRIGUES, R.R. Métodos fitossociológicos mais usados. Casa da Agricultura, v. 10, n.1 p. 20-24. 1988.

RODRIGUES, R.R.; MORELLATO, L.P.C.; JOLY, C.A.; LEITÃO FILHO, H.F. Estudo florístico e fitossociológico de um gradiente altitudinal de mata estacional mesófila semidecídua, na Serra do Japi. Revista Brasileira de Botânica, v.12, p. 7184. 1989.

RODRIGUES, R.R. Análise Estrutural das Formações Florestais Ripárias. In: SIMPÓSIO SOBRE MATA CILIAR, 1., Campinas, 1989. Anais. Campinas: Fundação Cargill, 1989. p. 99-119. 
RODRIGUES, R.R. Análise da vegetação às margens do Rio Passa Cinco Ipeúna, SP. Campinas, 1992. 334p. Tese (Doutorado) - Instituto de Biologia, Universidade Estadual de Campinas.

RODRIGUES, R.R. Fitossociologia de um trecho de floresta estacional semidecidual, Reserva Municipal de Santa Genebra, Campinas, SP. Naturalia. 1998 (submetido).

RODRIGUES, R.R. Florestas ciliares?: uma discussão nomenclatural. In RODRIGUES, R.R.; LEITÃO FILHO (1998). Florestas ciliares: uma visão multidisciplinar. Editora da Universidade Estadual de Campinas, Campinas, SP. no prelo.

ROSENFIELD, G.H. Sampling design for estimating change in land use and land cover. Photogrammetric Engineering \& Remote Sensing, v.48, n.5, p.793-801, 1982.

ROSENFIELD, G.H.; FITZPATRICK-LINS, K.; A coefficient of agreement as a measure of thematic classification accuracy. Photogrammetric Engineering \& Remote Sensing, v.52, n.2, p.223-227, 1986.

ROSSI, C.T. A Flora arbóreo-arbustiva da mata da Reserva da Cidade Universitária Armando Sales de Oliveira, São Paulo, SP. São Paulo, 1987. 270 p. Dissertação (M.S.) - Instituto de Biociências, Universidade de São Paulo.

ROZZA, A.F.; RIBEIRO, C.A. Estudo florístico e fitossociológico de fragmentos de mata ciliar dos campos da ESALQ, Piracicaba, SP. In: CONGRESSO DA SOCIEDADE BOTÂNICA DE SÃO PAULO, 8., 1992. Anais. 1992. p. 7-12.

ROZZA, A.F. Florística, fitossociologia e caracterização sucessional em uma floresta estacional semidecidual: Mata da Vírginia, Matão, SP. Campinas, 1997. 176p. Dissertação (M.S.) - Instituto de Biologia, Universidade Estadual de Campinas.

SADER, S.A.; STONE T.A.; JOYCE, A.T. Remote sensing of tropical forests: an overview of research and applications using non-photografic sensors. Photogrammetric Engineering and Remote Sensing, v.56, p. 1343-1351. 1990.

SALIS, S.M. Composição Florística e estrutura de um remanescente de mata Ciliar no rio Jacaré. Pepira, Brotas, SP. Campinas, 1990. 111 p. Dissertação (M.S.) - Instituto de Biologia, Universidade Estadual de Campinas. 
SALIS, S.M.; SHEPHERD, G.J.; JOLY,C.A. Floristc comparison of mesophytic semideciduous forests of the interior of state of São Paulo, Southeast Brasil. Vegetatio, v.119, p. 155-164. 1995.

SCOTT, J.M.; DAVIS, F.; CSUTI, B. et al. Gap Analisis: A Geographic Approach to Protection of Biological Diversity. Wildlife Monographs, v. 123, p. 1-41. 1993.

SETZER, J. Atlas climático e ecológico do Estado de São Paulo. São Paulo: Comissão Interestadual da Bacia Paraná-Uruguai/Cesp, 1966. 232 p.

SHIMABUKURO, M.T. Avaliação de classificadores espectrais de imagens LandsatTM em áreas rurais densamente ocupadas - o caso da região de Brotas e Torrinha, São Paulo, Brasil. Campinas, 1996. 177p. Dissertação (M.S.) - Instituto de Biologia, Universidade Estadual de Campinas.

SILVA, A.F. Composição florística e estrutura fitossociológica do estrato arbóreo da reserva Florestal Professor Augusto Ruschi, São José dos Campos, SP. Campinas, 1989. 163 p. Tese (Doutorado) - Instituto de Biologia, Universidade Estadual de Campinas.

SIQUEIRA, M.F. Análise florística e ordenação de espécies arbóreas da mata atlântica através de dados binários. Campinas, 1993. 143p. Dissertação (M.S.) - Instituto de Biologia, Universidade Estadual de Campinas.

SOKAL, R.R.; ROHLF, F.J. Biometry. 3.ed. San Francisco: W.H. Freeman, 1995.

SPURR, S.H.; BARNES, B.V. La Radiación Solar. Ecologia Forestal. AGT Editor, S.A. Cap. 4. 1982.

STEFFEN, C.A.; LORENZZETTI, J.A.; STECH, J.L.; SOUZA, R.C.M. Sensoriamento remoto: princípios físicos; sensores e produtos e sistema Landsat. São José dos Campos: INPE, 1981.81p.

STENBACK, J.M; CONGALTON, R.G. Using Thematic Mapper imagery to examine forest understory. Photogrammetric Engineering \& Remote Sensing, v.56, n.9, p.1285-1290, 1990.

STORY, M.; CONGALTON, R.G. Accuracy assessment: a user's perspective. Photogrammetric Engineering \& Remote Sensing, v.52, n.3, p.397-399, 1986. 
STRAHLER, A.H.; LOGAN, T.L.; WOODCOCK, C.E. Forest classification and inventory system using Landsat digital terrain and ground sample data. In: INTERNATIONAL SYMPOSIUM OF REMOTE SENSING OF ENVIRON, 13., 1979. Proceedings, p. 1541 - 1566.

STRAHLER, A.H. Stratification of natural vegetation for forest and rangeland inventory system using Landsat digital imagery and collateral data. International Journal of Remote Sensing, v.2, n.1, p. 15-41. 1981.

STRUFFALDI-DE-VUONO, Y. Fitossociologia do estrato arbóreo do Instituto de Botânica (São Paulo, SP). São Paulo, 1985. 213 p. Tese (Doutorado) - Instituto de Biociências, Universidade de São Paulo, SP,

SWAIN, P.H. Fundamentals of pattern recognition in remote sensing. In: SWAIN, P.H. DAVIS, S.M. (Ed.) Remote sensing: the quantitative approach. New York: McGrawHill, 1978. p.136-187.

TAMASHIRO, J.Y.; RODRIGUES, R.R.; SHEPHERD, G.J. Estudo florístico e fitossociológico da Reserva da Mata da Santa Genebra, Campinas, SP. Campinas, 1986. (Relatório Científico à FAPESP)

TOLEDO-FILHO, D.V.: LEITÃO-FILHO, H.F.: BERTONI, J.E.A.: BATISTA, E.A.; PARENTE, P.R. Composição florística do estrato arbóreo da Reserva Estadual de Águas da Prata (SP). Revista do Instituto Florestal, v.5, n.2, p.113-122. 1993.

TORRES, R.B. Estudos florísticos em mata secundária da Estação Ecológica de Angatuba (São Paulo, SP). Campinas, SP, 1989. 231p. Dissertação (M.S.) - Instituto de Biologia, Universidade Estadual de Campinas.

TROPPMAIR, H. A cobertura vegetal primitiva do Estado de São Paulo. Biogeografia, v.1, p. 1-10. 1969.

VAN GOOL, L.; DEWAELE, P.; OOSTERLINCK, A. Survey: texture analysis anno 1983. Computer Vision, Graphics, and Image Processing, v. 29, p. 336-357. 1985.

VETTORAZZI, C.A. Sensoriamento remoto orbital. Piracicaba: ESALQ, Depto. Engenharia Rural (Série didática do Departamento de Engenharia Rural), 1992. 129p. 
VICTOR, M.A.M. A devastação florestal. São Paulo: Sociedade Brasileira de Silvicultura. São Paulo, 1975.

VIEIRA, M.G.L.; MORAIS, J.L.; BERTONI, J.E.A.; MARTINS, F.R.; ZANDARIM, M.A. Composição florística e estrutura fitossociológica da vegetação arbórea do Parque Estadual de Vaçununga. Santa Rita do Passa Quatro - SP. II. Gleba Capetinga Oeste. Revista do Instituto Florestal, v.1, n.1, p.135-159. 1989.

WALTER, H.; LIETH, H. Klimadiagramm-Weltatlas. Ficher, Jena. 1960-67.

WANG, L. Vector choice in the texture spectrum approach. International Journal of Remote Sensing, v.15, n.18, p. 3823-3829. 1994.

WATANABE, S. (Coord.). Glossário de ecologia. 2. ed. São Paulo: ACIESP, 1997. 351p. (ACIESP. Publicação, 103)

WATT, A.S. Pattern and process in plant community. Journal of Ecology, v.35, p. 122. 1947.

WECHSLER, H. Texture analysis - a survey. Signal Processing, v.2, p. 271-282. 1980. WHITMORE, T.C. Tropical rain forest of the Far East. Oxford: Clarendon Press, 1975. 282p.

WHITTAKER, R.H. Evolution and measurement of species diversity Taxon, v. 21, p. $213-51.1972$.

WOODCOCK, C.E.; STRAHLER, A.H. The factor of scale in remote sensing. Remote Sensing Environ, v.21, p. 311-332. 1987.

ZICKEL, C.S. Fitossociologia e dinâmica do estrato herbáceo de dois fragmentos florestais do Estado de São Paulo. Campinas, 1995. 231p. Tese (Doutorado) Instituto de Biologia, Universidade Estadual de Campinas. 